\title{
A historiografia da música popular no Brasil (1971-1999)
}

Tese apresentada ao Programa de Pós-Graduação em História Social do Departamento de História da Faculdade de Filosofia, Letras e Ciências Humanas da Universidade de São Paulo, para a obtenção do título de Doutor.

Orientador: Prof. Dr. Marcos Francisco Napolitano de Eugenio

\section{Versão corrigida}

São Paulo 


\section{AGRADECIMENTOS}

À Marcos Napolitano, pela orientação competente, generosa e com plena liberdade intelectual.

À Tânia da Costa Garcia, pela participação nas banca de qualificação e pelas conversas esclarecedoras sobre temas deste estudo.

À José Geraldo Vinci de Moraes, pela participação no exame de qualificação com contribuições relevantes para a continuidade do trabalho.

À Lia Vera Tomás, pela confiança e estímulo em minha trajetória acadêmica.

À Elias Thomé Saliba, pela participação na banca de defesa com questões para reflexão.

À Adalberto Paranhos, pela participação na banca de defesa e pelas anotações de sua leitura atenta que contribuíram para a revisão do trabalho.

À Paulo Fernandes Baia, meu irmão, pelas muitas conversas sobre história, música e sociedade ao longo da vida, que se refletiram neste trabalho.

Aos familiares, amigos, colegas e pessoas queridas, Cláudia Soares de Oliveira, José Roberto do Carmo Jr., Josefina Pereira Baia, Juliano de Carvalho Vera Baia, Luciana Mourão Arslan, Renata Mancini, Ruy Barreto, Selma Santos Borges e Sheila de Carvalho Vera, por distintas e diversas contribuições.

À FAPESP, pela concessão da bolsa, que utilizei por 2 anos, e que foi fundamental nesse período para a realização da pesquisa.

Ao CNPQ, pela concessão da bolsa, que usufruí por um mês, mas que foi importante naquele momento.

Ao Departamento de História da USP, pela oportunidade da realização deste estudo.

Aos colegas do Curso de Música da Universidade Federal de Uberlândia.

À todos, que com pequenas contribuições, ajudaram muito a realização desta pesquisa. 


\section{RESUMO}

BAIA, S. F. A historiografia da música popular no Brasil (1971-1999). Tese de doutorado em História Social. São Paulo: Faculdade de Filosofia, Letras e Ciências Humanas, Universidade de São Paulo, 2010.

Esta tese apresenta um estudo da historiografia da música popular no Brasil, realizada nos programas de pós-graduação em História, nos estados de São Paulo e do Rio de Janeiro, no período delimitado entre o início da década de 1970 até o final da década de 1990. A pesquisa identifica e analisa temáticas, conteúdos, abordagens, conceitos, fontes e metodologias. Pretende também entender as agendas, dinâmicas e tendências de pesquisa, bem como seus influxos estéticos e ideológicos ao longo do tempo. Constitui-se num mapa analítico da historiografia da música popular no Brasil, a partir de uma perspectiva crítica. Apresenta uma reflexão histórica e teórico-metodológica, revisando o processo de formação e afirmação de um campo de estudos inscrito nas Ciências Humanas e, particularmente, na História.

Palavras-chave: Música popular, Historiografia, História da música, Música brasileira, Canção popular. 


\begin{abstract}
BAIA, S.F. The historiography of popular music in Brazil (1971-1999). Tese de doutorado em História Social. São Paulo: Faculdade de Filosofia, Letras e Ciências Humanas, Universidade de São Paulo, 2010.

This thesis presents a study on the historiography of popular music in Brazil, which was developed in post-graduate education programs in History, in the states of São Paulo and Rio de Janeiro, delimited within the timeframe between the beginning of the 1970's and the end of the 1990's. This work aims at identifying and analyzing thematics, contents, as well as approaches, concepts, sources and methodologies. Another purpose for this work is to comprehend the agendas and dynamics of the researches, as far as its trends and inclinations are concerned, along with the aesthetical and ideological inflows that appear over time. It consists of an analytical map of popular music historiography in the country, from a critical perspective. It presents a theoretical, methodological and also, historical reflection destined for a review of the process involving the formation and assertion of a field of studies inscribed in the area of Human Sciences and, particularly, in History.
\end{abstract}

Keywords: Popular music, Historiography, History of music, Brazilian music, Popular song. 


\section{SUMÁRIO}

$\begin{array}{ll}\text { INTRODUÇÃO } & 8\end{array}$

FONTES E PROCEDIMENTOS

PROCESSO FORMATIVO DE UM CAMPO DE ESTUDOS

CAPÍTULO 1

O LEGADO DOS MUSICÓLOGOS, MEMORIALISTAS E PRIMEIROS HISTORIADORES DA MÚSICA POPULAR NO BRASIL

1.1. TINHORÃO: DE JORNALISTA POLÊMICO A HISTORIADOR DA MÚSICA POPULAR 34

1.2. A DEFESA DA TRADIÇÃO NA MÚSICA POPULAR BRASILEIRA 39

CAPÍTULO 2

43

O ENSAIO ACADÊMICO: MOMENTO FORMATIVO DE UM CAMPO DE ESTUDOS. FUNDAMENTOS PARA A HISTORIOGRAFIA

2.1 ANOS 70: ENSAIOS MENOS POLÊMICOS E MAIS ANALÍTICOS. A FORMATAÇÃO DE 52 UM OBJETO DE ESTUDO.

2.2 AS PRIMEIRAS PESQUISAS ACADÊMICAS

2.3 TINHORÃO, WISNIK E CONTIER: LINHAS MESTRAS PARA A HISTORIOGRAFIA 78

2.3.1 Wisnik: uma leitura da formação da música brasileira $\quad 80$

2.3.2 Contier: nova relação entre história e música 86

CAPÍTULO 3

91

MAPA DA PRODUÇÃo NA ÁREA DE HISTÓRIA

3.1 A PESQUISA SOBRE AS “ORIGENS”: MOMENTO FORMATIVO DA MÚSICA 92

POPULAR NO BRASIL

3.2 HISTORIOGRAFIA DO SAMBA 96

3.3 MÚSICA E POLÍTICA $\quad 101$

3.4 HISTORIOGRAFIA DOS MOVIMENTOS E GÊNEROS MUSICAIS 107

3.5 HISTORIOGRAFIA E TRAJETÓRIAS INDIVIDUAIS 114

3.6 HISTÓRIA, MÚSICA E CIRCUITOS DE PRODUÇÃO E CONSUMO 118

3.7 HISTORIOGRAFIA, LINGUAGEM E TEMAS POÉTICOS. 122

3.8 A PESQUISA ACADÊMICA E SEUS DOMÍNIOS HISTORIOGRÁFICOS 123

3.9 VERTENTES HISTORIOGRÁFICAS EM OUTRAS DISCIPLINAS 127

3.10 PRINCIPAIS LINHAS TEMÁTICAS NAS PESQUISAS 132

$\begin{array}{ll}3.11 \text { QUESTÕES } & 134\end{array}$ 
CONCEITOS E TEORIAS: UM OLHAR PANORÂMICO

6.1 A CONSTITUIÇÃO DO CAMPO MUSICOLÓGICO: OS SIGNIFICADOS DE 205 "MUSICOLOGIA" E O PREFIXO "ETNO"

6.2 HISTÓRIAS DA MÚSICA E INTERSEÇÕES HISTÓRIA \& MÚSICA

6.3 A ANÁLISE DO DISCURSO DO TEXTO LITERÁRIO DAS CANÇÕES

6.4 ABORDAGENS HISTÓRICO-SOCIOLÓGICAS E ANÁLISE TÉCNICO-ESTÉTICAS: ALGUMAS REFLEXÕES

6.5 AS RELAÇÕES (E TENSÕES) ENTRE A PRODUÇÃO HISTORIOGRÁFICA, OS ESTUDOS SOBRE A MÚSICA POPULAR E AS MUSICOLOGIAS 


\section{INTRODUÇÃO}

O objetivo deste trabalho é analisar a produção acadêmica sobre música popular urbana no Brasil, realizada na pós-graduação na área de História, visando identificar e analisar os conteúdos, abordagens, conceitos, fontes e metodologias, entender as agendas, dinâmicas e tendências de pesquisa, bem como seus influxos estéticos e ideológicos ao longo do tempo. Ao fazer uma reflexão sobre a recente e crescente historiografia acadêmica (ou seja, alocadas em programas de pós-graduação universitários) da música popular, esta pesquisa pretende contribuir para a compreensão de como foram se constituindo as linhas principais de pensamento sobre esta moderna música urbana no Brasil. A periodização da pesquisa abrange desde as primeiras dissertações e teses sobre música popular realizadas no início dos anos 1970 até o final da década de 1990, momento em que se consolida a presença do tema no campo científico, e na área de História em particular, e já se encontra esboçado o atual quadro teórico metodológico com suas distintas vertentes. Mais precisamente, entre os anos de 1971, com a defesa do primeiro trabalho a ter a música popular como objeto, e 1999, considerado como final da década de 1990 e do século XX.

Ainda que não exista uma definição cabal de música popular aceita por todos os pesquisadores, está se formando um entendimento entre os estudiosos do campo acerca das características gerais desse objeto de estudo. Entende-se por música popular a música urbana, surgida a partir do final do século XIX, instrumental ou cantada, mediatizada, massiva e moderna. ${ }^{1}$ Naturalmente isso não quer dizer que não existiram, ao longo da história, outras músicas que pudessem ser classificadas de popular. Existem também em nossos dias, dependendo do sentido que se agregue à palavra popular. Mas, em geral, está associada à expressão música popular o caráter urbano, a música que surgiu nos grandes conglomerados pós-revolução industrial em estreita ligação com o mercado. Esta música tem um caráter massivo e sua produção, reprodução e consumo estão mediados por um amplo leque de influências socioculturais. Esta música constituiu-se num dos fenômenos culturais mais marcantes

\footnotetext{
1 A expressão "mediatizada, massiva e moderna" encontra-se na definição dada por Juan Pablo Gonzáles em Musicología popular en América Latina: síntesis de sus logros, problemas y desafíos. Revista Musical Chilena, № 195, p.38-64, janeiro-junho, 2001, p. 38.
} 
do século XX e grande parte da produção musical de nossa época se insere no amplo leque de manifestações musicais que chamamos música popular. Ela esteve presente nos principais processos sociais da história recente, como forma de lazer e entretenimento, ligada à dança e ao convívio social, mas também como veículo de luta ideológica, de mudanças comportamentais, estando sempre presente nos movimentos de juventude, constituindo-se assim num importante documento historiográfico.

Nos últimos anos, a literatura sobre música popular urbana no Brasil, e também no plano internacional, tem apresentado um crescimento exponencial. Este crescimento dá-se tanto no plano da produção acadêmica, com a elaboração de artigos e estudos sobre este objeto, como também no mercado editorial que tem continuamente lançado títulos dedicados ao assunto. Em minha dissertação de mestrado, ${ }^{2}$ listei 258 dissertações e teses sobre música popular, realizadas em diversos ramos do conhecimento apenas no Estado de São Paulo entre 1971 e 2004. A distribuição cronológica da produção apresentou um crescimento significativo: entre 2000 e 2004 foram realizadas 125 pesquisas, praticamente o mesmo que em todo o período anterior. Reflexo do interesse da sociedade pelo tema, o crescimento quantitativo - e também qualitativo - da literatura sobre música popular atinge uma proporção que tem tornado inclusive muito difícil acompanhar a evolução da produção.

O primeiro impulso nos estudos acadêmicos sobre a música popular urbana não se deu, como se poderia considerar natural, a partir da área de Música, ainda que, nos últimos anos, a área venha apresentando um aumento expressivo na produção de pesquisas sobre o tema, já consolidado dentro da musicologia brasileira, mesmo que ainda existam algumas resistências. Desde o momento inicial, os estudos acadêmicos sobre a música popular no Brasil foram um "projeto" da área de Humanidades e Ciências Sociais de uma maneira ampla. Embora as primeiras pesquisas estivessem mais concentradas nas áreas de Letras, Sociologia e Comunicação, tivemos também, até 1982, trabalhos em Antropologia, Filosofia, Linguística, História e Psicologia. De fato, o estudo deste complexo fenômeno cultural contemporâneo requer a utilização de um diversificado instrumental teórico-metodológico na busca de uma visão integrada dos

\footnotetext{
2 BAIA, Silvano Fernandes. A pesquisa sobre música popular em São Paulo. Dissertação de mestrado em Música. Instituto de Artes da UNESP, São Paulo, 2005.
} 
vários aspectos sobre os quais a moderna música popular urbana pode ser observada. Por exemplo, podem ser objetos de estudo desde as questões intrinsecamente musicais, de estruturação da linguagem musical, passando pelo texto literário, quando existente, e sua compatibilização com o texto musical, até os diversos aspectos da produção, reprodução e recepção do material musical e suas conexões com a vida dos indivíduos e das sociedades.

A porta de entrada da música popular na Universidade foi a letra das canções, que, durante a década de 1960, apresentaram um expressivo enriquecimento semântico. Ainda que alguns trabalhos pioneiros na área de Sociologia tenham também observado o fenômeno das transformações dos processos de produção e reprodução musical em curso, foi na área dos estudos literários que começou a esboçar-se um campo de estudos da canção popular. Desenvolveu-se nas áreas de Letras e Comunicação uma metodologia de estudo baseada na análise do discurso do texto literário das canções, da qual muitas vezes se derivavam reflexões históricosociológicas. Esta metodologia, que marcou fortemente o campo nesta fase formativa, foi sendo paulatinamente superada. Porém, algumas visões desatualizadas acerca do estado do conhecimento no campo, especialmente naquelas parcelas da musicologia ainda refratárias à música popular, tendem a ver esses estudos como ainda exclusivamente voltados ou dependentes da análise do texto literário. Desde as primeiras pesquisas, está em curso um processo de construção de um instrumental teórico adequado ao estudo do objeto, nos diversos aspectos que ele pode ser observado, que vai se configurando nas elaborações, confluências, embates e polêmicas internas e externas ao campo. Minha tese é um mapa analítico deste processo, dentro do qual me posiciono criticamente. Neste sentido, este trabalho tenta construir uma reflexão teórico-metodológica e ao mesmo tempo historiográfica, revisando a história da constituição e afirmação de um campo de estudos dentro das Ciências Humanas e, particularmente, da História.

A área de História começa nos anos 1980, timidamente, a tomar a música popular como objeto de estudo, que pode ser considerado incorporado à área por volta do final da década de 1990, ainda que até hoje venha buscando um melhor posicionamento na hierarquia interna da disciplina. Quando esses estudos 
historiográficos acadêmicos se iniciam, existia uma concepção tacitamente estabelecida, mas amplamente aceita, do que seria música popular brasileira: ela era apreendida como uma certa linhagem desenvolvida em torno da música popular do Rio de Janeiro popularizada nacionalmente na década de 1930 através do rádio, num momento em que se operava a construção de uma identidade nacional. Existiam também narrativas históricas nesta visão de senso comum de música popular brasileira, que incluíam concepções de nacionalidade e de autenticidade enquanto cultura popular, bem como um conjunto de autores e obras canônicas. Estas narrativas, que vinham se construindo a partir dos primeiros textos sobre música popular escritos nos anos 1930, tinham, portanto, cerca de meio século quando se iniciaram as pesquisas na área de História nos anos 1980. Mesmo considerando-se os intensos debates estéticopolíticos ocorridos na década de 1960 e a modernização da linguagem musical ocorrida a partir da bossa-nova, ainda eram marginais aqueles que como Raul Seixas diziam que não tinham nada a ver com a linha evolutiva da música popular brasileira. Mas os ensaios acadêmicos dos anos 1970 e 1980, tanto os artigos e livros voltados para uma circulação ampla, como os estudos pioneiros na pós-graduação, ofereceram problemas, questões e novos olhares para o fenômeno da música popular urbana que se constituíram em referências para a historiografia acadêmica que surgia. ${ }^{3}$

De início, os pesquisadores se enfrentaram com a escassez e dificuldade de acesso às fontes primárias, com poucos e desorganizados acervos públicos e parte importante da documentação disponível apenas em arquivos particulares. Assim, as pesquisas sobre música popular que estudavam os eventos das primeiras décadas do século $\mathrm{XX}$, num primeiro momento, recorreram a fontes secundárias, narrativas de memorialistas e à historiografia de pesquisadores não acadêmicos. Como as narrativas e a própria seleção das fontes destes autores foram, em grande parte, orientadas por

\footnotetext{
3 Este processo formativo de um pensamento historiográfico sobre música popular no Brasil já foi estudado anteriormente por outros pesquisadores do campo. Especialmente os artigos de José Geraldo Vinci de Moraes e Marcos Napolitano se constituíram em referências importantes para esta tese: MORAES, José Geraldo Vinci de. Os primeiros historiadores da música popular urbana no Brasil. In: ArtCultura. Uberlândia: EDUFU, v.8 no 13, 2006, p.117-133; História e música: canção popular e conhecimento histórico. Revista Brasileira de História, no 39. São Paulo: Humanitas, 2000, p. 203-221; NAPOLITANO, Marcos. História e música popular: um mapa de leituras e questões. In: Revista de História. São Paulo: FFLCH-USP, no 157, 2007, pp. 153-171; A historiografia da música popular brasileira (1970-1990): síntese bibliográfica e desafios atuais da pesquisa histórica. In: ArtCultura. Uberlândia: EDUFU, v.8 no 13, 2006, p.135-150. Ver também: CONTIER, Arnaldo. Música no Brasil: História e interdisciplinaridade. Algumas interpretações (1926-1980). In: Anais do XVI Simpósio da ANPUH, 1991, pp. 151189.
} 
suas concepções estéticas e ideológicas, sua utilização como fonte e referencial privilegiado para outros estudos tendia a reproduzir e consolidar uma determinada leitura dos fatos, uma certa visão da história, por vezes sem a devida contextualização crítica. Por outro lado, o estudo dos eventos mais recentes, da segunda metade do século $\mathrm{XX}$, para os quais as fontes estavam mais disponíveis, também ecoavam influências estético-ideológicas, uma vez que os pesquisadores geralmente tinham vínculos políticos ou afetivos com uma determinada corrente musical. 0 samba carioca da década de 1930, gênero central na construção de um discurso sobre música popular no Brasil, com confluências no pensamento social brasileiro, e a MPB dos anos 1960, que canalizou as lutas político-culturais daquele momento histórico, foram tomados como objetos privilegiados nos estudos pioneiros. Considere-se que, nestas pesquisas, foi se construindo uma metodologia, até então inexistente, para a abordagem da história da música popular, ou das relações entre história e música, questão ainda não plenamente resolvida. Também o contexto no qual estes trabalhos foram realizados, momento de redemocratização do país após anos de regime militar, bem como o ambiente intelectual da Universidade brasileira, precisam ser observados. De toda forma, as visões que foram se configurando até por volta dos anos 1980 como versão predominante da história da música popular no Brasil, mereceram destes primeiros historiadores acadêmicos uma reflexão quanto aos documentos e aos pressupostos estéticos e ideológicos em que se fundamentavam, num processo contínuo de construção do conhecimento histórico. Novas pesquisas tem ampliado os horizontes e contribuído para uma maior compreensão da música no Brasil e da própria história política, social e cultural do país. É a história desta historiografia o objeto desta pesquisa.

\section{FONTES E PROCEDIMENTOS}

As fontes para a realização deste estudo são as dissertações de mestrado, teses de doutorado e de livre docência realizadas na área de História nos estados de São Paulo e do Rio de Janeiro até 1999. A inclusão de artigos, comunicações em congressos e outras publicações tornaria a coleta de dados muito dispersiva, embora aqueles 
trabalhos mais mencionados serão considerados na análise. Da mesma forma, a pretensão de uma abrangência nacional criaria dificuldades, dada a dimensão continental do país e a dificuldade de acesso às teses e dissertações produzidas em outros estados. Acreditamos que as dissertações e teses realizadas em São Paulo e Rio de Janeiro oferecem um painel representativo da produção acadêmica, até porque são muito poucos e pontuais os trabalhos realizados na área de História em outros estados até 1999, considerando-se o processo de consolidação do objeto e a juventude da maioria dos programas de pós-graduação atualmente existentes. Os Estados de São Paulo e do Rio de Janeiro são os mais produtivos em termos de pesquisas sobre música popular, ainda que hoje existam outros centros importantes, e sua produção é uma amostragem muito significativa da produção nacional.

Para efeito da seleção dos trabalhos, considerou-se como pertencentes à historiografia da música popular as teses e dissertações que: 1) tenham a música popular, dentro da concepção aqui apresentada, como objeto principal; 2) utilizam a música popular como fonte primordial de pesquisas que visam o estudo de outros objetos; 3) pesquisas que tratam do campo musical de forma mais ampla, nas quais a música popular tenha presença relevante; 4) pesquisas sobre produção, reprodução e consumo musical. Dentro do conjunto da produção no período determinada pela periodização adotada, a proposta foi listar todas as pesquisas realizadas.

$\mathrm{Na}$ seleção do material, foram utilizados os estudos bibliográficos dos trabalhos do campo anteriormente realizados. ${ }^{4}$ Foi realizada também uma busca nos sites da CAPES e nas bibliotecas on-line das Universidades na Internet. Além disso, a própria leitura dos textos contribuiu para este mapeamento através das citações e bibliografias. Assim, é improvável que algum trabalho tenha escapado desta triagem, mas é possível, caso ele não tenha sido anteriormente detectado nem mencionado nas demais pesquisas do campo. Foram relacionadas 35 dissertações e teses, que estão

4BAIA, Silvano Fernandes. A pesquisa sobre música popular em São Paulo. Dissertação de mestrado em Música. IAUNESP, 2005; GOMES, Tiago de Melo. Estudos acadêmicos sobre a música popular brasileira: levantamento bibliográfico e comentário introdutório. In: História: questões \& debates. Editora da UFPR, n. 31, 1999, pp.95-111; NAVES, Santuza Cabraia et al. Levantamento e comentário crítico de estudos acadêmicos sobre música popular no Brasil. ANPOCS bib, no 51, 2001; NAPOLITANO, Marcos. História e música popular: um mapa de leituras e questões. In: Revista de História. São Paulo: FFLCH-USP, no 157, 2007, pp. 153-171; A historiografia da música popular brasileira (1970-1990): síntese bibliográfica e desafios atuais da pesquisa histórica. In: ArtCultura. Uberlândia: EDUFU, v.8 no 13, 2006, p.135-150. ENTRE a história e a memória da música. Banco de dados. Disponível em: $<$ www.memoriadamusica.com.br>. 
listadas no Anexo. A definição desse corpo documental, por mais que se tenha buscado a objetividade, contém um certo arbítrio; outras concepções de música popular ou critérios de seleção poderiam resultar em listas mais reduzidas ou ampliadas. Mas, ainda assim, certamente constitui uma base consistente para uma reflexão acerca desta produção historiográfica dentro da periodização definida. As 35 dissertações e teses, que compõem as fontes desta pesquisa, estão listados no Anexo com dados complementares. Nas referências, estão relacionados não apenas estes trabalhos, mas também pesquisas realizadas na área de História fora de nossa periodização e trabalhos realizados em outras áreas considerados relevantes para a discussão da historiografia, como referências, exemplos ou citações. Como os trabalhos sobre música popular no período, nas diversas áreas, constituem um conjunto muito grande de pesquisas, foram listados como fontes apenas aqueles que foram analisados ou citados.

No estudo desta produção, quatro aspectos estão em foco: 1) Análise dos objetos, da argumentação e das principais conclusões dos trabalhos e definição de um panorama geral das principais abordagens e linhas de pesquisa; 2) Conceitos e teorias: serão investigados quais são os principais conceitos e categorias utilizados nas pesquisas, eventuais premissas de ordem estética em que se apóiam e instrumental teórico em que estão referenciados; 3) Documentação e sua utilização: serão verificadas quais as fontes que informam as pesquisas assim como aspectos da seleção do material; 4) Metodologia: reflexões acerca das relações entre história e música e história da música como encontro entre as disciplinas histórica e musicológica, com ênfase no manejo analítico das fontes musicais e extra-musicais e nas conexões entre análise técnico-estética da música e abordagens histórico-sociológicas. Estes aspectos serão estudados numa perspectiva temporal, na tentativa de compreender a construção do pensamento acadêmico que vai se formando em torno da música popular no Brasil.

Uma vez definido o corpo documental de trabalhos para esta pesquisa, foi realizada uma leitura crítica com fichamento dos trabalhos. A perspectiva desta leitura foi localizar, no texto das pesquisas, elementos para a compreensão do trabalho, tais como seus objetivos, as metodologias e conceitos empregados, as teorias em que se fundamentam (ou eventuais premissas ideológicas) e conclusões, estando estes 
elementos explícitos ou não, numa tentativa de leitura heurística e objetiva dos dados apresentados. Para facilitar o posterior cruzamento destes dados, foi elaborado um fichamento com os seguintes itens: 1) objetivos da pesquisas; 2) fontes utilizadas primárias e secundárias; 3) conceitos, categorias e instrumentais teóricos utilizados; 4) abordagens metodológicas; 5) periodizações; 6) gêneros musicais ou personalidades estudadas, quando for o caso; 7) obras analisadas, quando existirem; 8) conclusões do autor e 9) considerações a partir da leitura.

\section{PROCESSO FORMATIVO DE UM CAMPO DE ESTUDOS}

Embora o objeto deste estudo seja a produção realizada no âmbito da Universidade, muita coisa já tinha sido pensada, dita e escrita sobre música popular antes que se iniciasse o processo de legitimação deste tema dentro do campo científico. Podemos afirmar que quatro grandes referências inspiraram e informaram as primeiras pesquisas acadêmicas realizadas na década de 1970 e 1980: a) o discurso sobre música popular presente nos textos de musicólogos como Mário de Andrade, Renato Almeida e Oneyda Alvarenga; b) a historiografia não acadêmica da música popular no Brasil, realizada por memorialistas, jornalistas, colecionadores, músicos e amadores a partir da década de 1930; c) o debate entre intelectuais nos anos 1960 acerca dos rumos da música popular e a publicação de importantes ensaios nos anos 1970 e 1980; d) as elaborações teóricas da Sociologia da Comunicação, da Teoria da Informação, da Teoria Literária e das semióticas ainda em processo de desenvolvimento.

A partir dos anos 1970, temos a publicação de ensaios e das primeiras dissertações de mestrado, impulsionadas, entre outros fatores, pela reforma da pósgraduação no Brasil. As elaborações dos intelectuais sobre música popular não estavam mais direcionadas para a participação no debate estético-ideológico visando incidir nos rumos da canção popular no país, como na década anterior, pois a discussão tinha se esvaziado com o recrudescimento da ditadura militar e o aumento da repressão política e cultural após a edição do AI-5 em dezembro de 1968, que alterou a agenda política da esquerda. A canção popular emergia dos anos 1960 com status privilegiado na cultura 
nacional, a MPB estava institucionalizada e existia um "acordo" numa parcela do campo de produção em torná-la peça de resistência política e cultural à ditadura, o que contribuía para diluir diferenças estéticas. Desenvolveu-se na área de Letras e Comunicação uma linha de pesquisa baseada na análise do discurso do texto literário das canções, a partir do qual muitas vezes se derivavam discursos históricosociológicos. Existiram também, no período, estudos de Sociologia da Comunicação. As dissertações pioneiras apresentavam um estilo ensaístico, uma metodologia em construção, escassez de pesquisa de fontes primárias, estavam muito referenciadas na historiografia então disponível e fortemente marcadas pelas circunstâncias da conjuntura política e pela presença do marxismo no ambiente universitário. Durante os anos 1980, temos um aumento quantitativo das pesquisas, de sua distribuição pelas áreas e inicia-se uma busca por uma metodologia mais definida para o estudo da canção, a exemplo das pesquisas de Luiz Tatit, cujas elaborações metodológicas iriam se tornar mais popularizadas apenas a partir dos anos 1990 com a publicação de textos mais acessíveis do que os seus escritos de formação. Em que pese suas elaborações constituírem uma original contribuição metodológica para a compreensão do objeto canção, seus estudos não tiveram grande repercussão na historiografia em função do caráter sincrônico de sua teoria. A partir dos anos 1980, foram influentes os textos de José Miguel Wisnik, na elaboração do lugar do popular e do erudito na cultura nacional, e de Arnaldo Daraya Contier, na proposição de uma nova abordagem para o estudo das relações entre música e política numa perspectiva diretamente historiográfica, sendo estes pesquisadores referências importantes até hoje. Nos anos 1990, ocorre o boom nas pesquisas e temos a consolidação dos estudos sobre a música popular no campo científico. As áreas de Musicologia e de História entram de maneira mais sistemática nas pesquisas, aumentando a densidade das elaborações e derrubando alguns mitos que vinham se construindo a exemplo da onipresença da síncope e a idealização da malandragem, temas caros à historiografia do samba. Especialmente no primeiro momento, mas também durante todo o período, foi muito grande a influência do marxismo em leituras que procuravam situar a música popular no contexto da luta de classes. Talvez para evitar se chocar frontalmente com estas concepções, a questão do mercado poucas vezes foi estudada em profundidade por outras linhas de pensamento. 
Neste ponto, o campo se ressente da não incorporação de pesquisas na área de Economia. Também existem trabalhos em que a questão étnica tem um peso exacerbado, na visão de um Brasil dual apoiada no conceito de raça. Trabalhos como o de Hermano Vianna vêm se contrapondo a ideias deste tipo.

É interessante observar a existência de certa sincronia temporal entre os estudos musicais populares no Brasil, na América Latina e nos Estados Unidos e Europa. De uma maneira geral, esses estudos começaram nos anos 1970 e foram precedidos por ensaios da década anterior que procuravam compreender a revolução musical e tecnológica em curso, a exemplo dos trabalhos de Umberto Eco e Edgar Morin. Na década de 1970, o fenômeno cultural da moderna música popular urbana começou a ser tomado como objeto de estudo por pesquisadores acadêmicos em diversos países. 0 jazz já havia sido aceito na academia norte-americana por volta do final dos anos 1960, mas este é um caso muito particular, dado o status social adquirido pelo gênero naquele país, elevado à condição de "música artística". ${ }^{5}$ Ainda assim, lembremos que Eric Hobsbawm publicou, entre as décadas de 1950 e 1960, textos sobre o jazz com o pseudônimo de Francis Newton, que utilizava para crítica musical ${ }^{6}$.

Os pioneiros na afirmação de um objeto de estudo até então desconsiderado na hierarquia de valores acadêmicos foram os chamados scholar fans, os fãs acadêmicos, músicos ou aficionados, pessoas de alguma forma envolvidas com esta produção. ${ }^{7} \mathrm{~A}$ existência de diversos estudos acadêmicos sobre a música popular durante a década de 1970 na Europa e Estados Unidos e o crescente interesse de pesquisadores de diversas áreas motivaram a realização de uma conferência internacional de pesquisa sobre música popular, em junho de 1981 em Amsterdã, onde foi fundada a International Association for the Study of Popular Music (IASPM) e no mesmo ano foi lançada a primeira edição do jornal Popular Music, editado pela Cambridge University Press, até hoje a mais importante publicação do campo no plano internacional. Os estudos sobre

\footnotetext{
5 SNYDER, Randy L. College jazz education during the 1960: its development and acceptance. PhD Thesis. University of Houston, USA, 1999.

${ }^{6}$ HOBSBAWM, Eric. J. História social do jazz. Rio de Janeiro: Paz e Terra, 1990. Título original: The Jazz Scene. Hobsbawm utilizava, entre a segunda metade da década de 1950 e o início dos anos 1960, o pseudônimo de Francis Newton em artigos sobre o jazz e, por vezes, também música popular, para a revista New Statemans.

7 É bastante ilustrativa a passagem de Nicholas Cook na qual ele, falando do surgimento de uma nova geração de musicólogos que buscou ampliar os horizontes da disciplina, comenta a situação desses pesquisadores nos anos 1960: "É fácil imaginar como incipientes musicólogos, trabalhando durante o dia em, digamos, problemas textuais na música do século XVI, pela noite se uniam à contracultura fumando, falando de política, escutando música de protesto." COOK, Nicholas. Agora somos todos (etno)musicólogos. Ictus, n.7, 2006, p.9.
} 
música popular na América Latina começaram simultaneamente ao hemisfério norte, ainda que, por aqui, tenham tido um desenvolvimento posterior mais lento. ${ }^{8}$ Mas se existe em certo nível esta sincronia temporal no desenvolvimento das pesquisas em diversos países, a integração e a troca de experiências e elaborações iriam demorar mais tempo a ocorrer, e as pesquisas tiveram seus objetos e ritmos ditados pelas especificidades nacionais. No Brasil, a formação de um corpo conceitual desenvolvido a partir das características específicas do nosso universo cancional, tais como o lugar sociocultural da música popular, seus entrecruzamentos complexos com a política e outras séries culturais, demonstra originalidade na formação do campo em relação à agenda de estudos do mundo anglo-americano. Entretanto, pontos importantes nas pesquisas no hemisfério norte, como as questões de gênero, identidade e juventude, bem como suas elaborações teórico-metodológicas, vêm sendo recentemente incorporadas pelo campo no país.

Estes trabalhos pioneiros da década de 1970 e 1980 fundaram um campo de estudos que vem crescendo e se consolidando na universidade brasileira. Desde então muitos passos foram dados na construção de teorias e elaboração de metodologias para o estudo da música popular. Porém, este passo inicial foi fundamental não apenas no sentido de legitimação do objeto, mas também na apresentação de elaborações que, através da reflexão crítica, fizeram aumentar o conhecimento da sociedade sobre o tema. Nos anos 1990, a música popular se consolida como objeto de estudo para a área de História e nos primeiros anos do século XXI, já fora da periodização desta pesquisa, o número de estudos historiográficos cresceu de maneira exponencial. Esta produção significou um aumento do conhecimento da história social da música no Brasil e da própria história do país. Nesta leitura crítica dos primeiros trabalhos e daqueles que os sucederam até o final dos anos 1990, é preciso destacar a sua contribuição e reconhecer sua importância decisiva na construção do atual estado do conhecimento. Este período constituiu uma fase formativa dos estudos da música popular no geral, e da historiografia em particular. Podemos nos perguntar se o campo já superou esta fase formativa e chegou a se constituir como um sistema mais estruturado, no qual as obras

\footnotetext{
8 GONZÁLES, Juan Pablo. Musicología popular en América Latina: síntesis de sus logros, problemas y desafíos. Revista Musical Chilena, no 195, p.38-64, janeiro-junho, 2001.
} 
se comunicam e os problemas e conceitos interagem. Esta é uma das problemáticas geradoras desta tese.

Se olharmos para o conjunto da historiografia, acadêmica ou não, considerando sua elaboração ao longo do tempo, podemos perceber no processo de sua construção, com tensões e contradições, como foram se sucedendo os temas e questões, as elaborações sobre eles, como foram se apresentando e sendo debatidas as teorias e como estas foram sendo incorporadas ou descartadas. Acredito que o estado do conhecimento que vai se formando em torno da música popular é devedor de todos estes trabalhos, mesmo daqueles que apresentaram elaborações que foram refutadas posteriormente, pois conduziram à reflexão e à busca de outros caminhos.

Para finalizar esta introdução, é preciso fazer uma última observação importante. Serão analisados textos escritos entre as décadas de 1970 e 1990. Portanto, alguns deles têm cerca de 40 anos de existência, período ao longo do qual o mundo passou por grandes e imprevisíveis transformações políticas, sociais e culturais, a música mudou, bem como suas formas de produção, reprodução e consumo estão em transformação num processo cujo desfecho ainda não está claramente definido. Tudo isto impôs novos desafios e novas formas de pensamento. A própria maneira de pensar a história sofreu grandes mudanças a partir dos anos 1970. Muitos dos autores dos trabalhos que vamos analisar são hoje professores de conceituadas universidades do país e estão entre as principais referências para o debate sobre música popular. Aqueles que deram continuidade às pesquisas sobre o objeto estão, naturalmente, num grau de elaboração superior ao momento de realização de seus trabalhos de pósgraduação, e encontram-se entre os maiores especialistas do assunto. É preciso deixar claro que o objetivo não é discutir a produção destes intelectuais como um todo, mas analisar suas pesquisas num momento específico, dentro da perspectiva de uma história da historiografia. Este trabalho é devedor de todos estes textos, mesmo daqueles dos quais o tom de discordância fica patente, e isto não apenas por serem eles as fontes desta pesquisa. Inclusive nos momentos em que apresento elaborações que tentam ser originais, a leitura destes trabalhos ampliou minha compreensão da história da música popular; depois de ler todo este rico material, é difícil saber exatamente o que é elaboração própria, assimilação ou ainda reelaboração de idéias alheias. Ainda 
que, de um ponto de vista crítico, que espero que tenha utilidade para futuras pesquisas, este trabalho tem uma visão respeitosa dessa produção e dos pesquisadores pioneiros.

Esta tese está dividida em seis capítulos. No Capítulo 1, será mostrado como, a partir do desinteresse dos intelectuais do nacionalismo musical pela música popular, esta foi tomada como objeto por escritores não acadêmicos. Será observada a formação de uma corrente de memorialistas, jornalistas, radialistas, músicos e aficionados que, em estreita ligação com o campo de produção, constituíram-se nos primeiros historiadores da música popular no Brasil. 0 herdeiro e expoente máximo desta linhagem de estudiosos da música urbana popular é José Ramos Tinhorão, cuja obra merece destaque especial, por elevar esta vertente historiográfica a um patamar superior, ainda que a verve excessivamente polemista e normativa do autor prejudique sua argumentação. De conjunto, ainda que com nuanças interpretativas, esta corrente caracteriza-se pelo nacionalismo e pela defesa da idéia de "autenticidade" e "tradição" da música popular no Brasil articulada em torno de uma linhagem da música popular do Rio de Janeiro.

No Capítulo 2, será analisado o ensaísmo acadêmico dos anos 1970 e 1980, entendido como publicações de artigos ou livros e primeiras pesquisas de pósgraduação, conforme já abordado nesta introdução. 0 capítulo inicia com a contraposição às posições nacionalistas e conservadoras que tiveram em Tinhorão seu principal arauto, expressas no livro Balanço da Bossa, de Augusto de Campos, publicado ainda no calor dos debates dos anos 1960. A seguir, dentre os ensaios do período, terão destaque os livros Música popular e moderna poesia brasileira, Música popular: de olho na fresta, Samba, o dono do corpo, e o artigo Música sertaneja: a dissimulação na linguagem dos humilhados, textos que apontaram caminhos e se tornaram referências nas pesquisas. Iremos observar os trabalhos pioneiros realizados nas áreas de Letras, Comunicação e Sociologia, com destaque para os textos que apresentaram reflexões de caráter histórico-social. 0 capítulo se encerra com um olhar para os trabalhos de José Miguel Wisnik e Arnaldo Contier, que se constituíram, ao lado dos textos de Tinhorão, com distintas abordagens, concepções e metodologias, em pavimentos do campo historiográfico. 
O Capítulo 3 apresenta um mapeamento da produção realizada nos programas de pós-graduação em História, distribuída naquelas que parecem ser as principais linhas temáticas de pesquisa, destacando seus temas e conclusões em linhas gerais. Esta produção será também localizada em relação aos domínios da disciplina histórica, aos quais serão agregados outros trabalhos que apresentem uma perspectiva historiográfica desenvolvidos em outras disciplinas. Ao final desta apresentação da produção, será feita uma reflexão sobre os principais temas e questões propostos pelas pesquisas em foco.

O Capítulo 4 está dedicado aos conceitos e teorias que orientam as distintas leituras da história encontradas nos trabalhos. As principais vertentes teóricas que se pode localizar nesta historiografia são aquelas de inspiração marxista, consideradas em suas diversas leituras, desde as mais ortodoxas até as linhas renovadas do marxismo ocidental como os Estudos Culturais Ingleses, por um lado, e as linhas identificadas com a Nova História e com o trabalho de historiadores e cientistas sociais que pensaram a história da cultura e influenciaram ou dialogaram com suas posições, por outro.

No Capítulo 5, são abordados dois aspectos que dizem respeito ao trato com as fontes na historiografia da música popular: a) a utilização da partitura e do fonograma como fontes na pesquisa histórica, a partir de uma reflexão e algumas considerações conceituais sobre os suportes para a composição e circulação da música, dos quais a notação em pentagrama e a gravação são as principais, mas não as únicas; b) um segundo tópico está dedicado a alguns aspectos relacionados à seleção do material musical das pesquisas, que, na grande maioria, no recorte cronológico deste estudo, se moveu em torno de um repertório que constitui uma linhagem dentro da música popular no Brasil.

O Capítulo 6 apresenta uma reflexão sobre a história da música e as relações entre história e música. 0 centro desta reflexão é o problema metodológico da compatibilização entre abordagens histórico-sociológicas e análise técnico-estética, ou seja, a articulação entre texto e contexto, sincronia e diacronia. No sentido de melhor se entender o olhar das musicologias para a história da música, é apresentado um breve histórico da disciplina. Na avaliação das posições em questão, será desenvolvida a 
consideração de que os embates epistemológicos não podem ser vistos de maneira dissociada das dinâmicas e lutas hierárquicas internas ao campo científico. 


\title{
CAPÍTULO 1 \\ O LEGADO DOS MUSICÓLOGOS, MEMORIALISTAS E PRIMEIROS HISTORIADORES DA MÚSICA POPULAR NO BRASIL
}

\begin{abstract}
Duas linhas de força tensionam o entendimento da música no Brasil e projetam-se nos livros que contam sua história: a alternância entre reprodução dos modelos europeus e descoberta de um caminho próprio, de um lado, e a dicotomia entre erudito e popular, de outro. Como uma espécie de corrente subterrânea que alimenta a consciência dos artistas, críticos e ouvintes, as linhas de força vêm à tona, regularmente, pelo menos desde o século XIX. Mobilizadas por dinâmicas culturais mais amplas, de que a música é parte, ou fermentadas no campo musical, com energia para vazar sobre outros domínios da cultura, elas se manifestam de maneira dramática em alguns momentos da história. ${ }^{9}$
\end{abstract}

Esta proposição de Elizabeth Travassos é o parágrafo de abertura do livro Modernismo e música brasileira, formulação que sintetiza grande parte dos debates sobre a música no Brasil. Entretanto, acredito que se poderia aprimorar esta síntese com a inclusão de uma terceira linha de força, que é o embate entre "modernidade" e "tradição", e de um problema que atravessa toda a discussão, que são as relações com o mercado de bens culturais. Naturalmente, este embate entre tradição e modernidade está, em alguns aspectos, relacionado com as outras duas linhas de força propostas, mas ele tem relevância por si só e é uma questão que continua na ordem do dia, tal a quantidade de discursos e manifestações práticas vinculadas às ideias de "raiz" e de "autenticidade" oriundas do campo de produção nos dias atuais. Por outro lado, o texto de Travassos encontra-se num livro sobre o modernismo, razão pela qual a autora fala em "reprodução de modelos europeus". Mas, pensando na música brasileira como um todo ao longo do século $\mathrm{XX}$, se nas primeiras décadas a questão da influência estrangeira estava relacionada com os modelos vindos da Europa, especialmente da Itália, Alemanha e França, com o passar do tempo, principalmente após a 2 $2^{\text {a }}$ Guerra Mundial, a grande influência estrangeira será da música dos Estados Unidos e, depois dos anos 1960, também da Inglaterra.

Assim, reelaborando a proposição de Travassos, podemos dizer que três linhas de força tensionam o entendimento sobre a música no Brasil e direcionam o debate: as

\footnotetext{
9 TRAVASSOS, Elizabeth. Modernismo e música brasileira. Rio de Janeiro: Zahar, 2000, p.7.
} 
dicotomias entre brasilidade e influências estrangeiras, entre o erudito e o popular e entre modernidade e tradição. De um modo geral, estas tensões estão no centro da maioria das narrativas históricas sobre a música no Brasil. Uma outra questão muito presente na articulação dos discursos é a relação entre produção musical e mercado de bens culturais, por vezes considerada de maneira simplista e reducionista como relação entre produção artística e comercial.

Estas questões já se encontravam presentes na formação do projeto do nacionalismo musical brasileiro, o primeiro grande projeto estruturado para uma musica nativa, brasileira, uma vez que o folclore e a música popular se desenvolviam mais espontaneamente. Tendo surgido de maneira ainda embrionária no final do século XIX, o nacionalismo ganhou força na década de 1920 e consolidou-se como corrente hegemônica no campo da música erudita brasileira nos anos 1930 com a liderança de Mário de Andrade, mantendo esta primazia até meados da década de 1960. O projeto nacionalista previa a construção de uma música artística brasileira a partir da utilização do material advindo da música popular, entendida como folclore rural e urbano. Ou seja, uma música que, partindo dos princípios estruturais e estéticos da música surgida na Europa, teria seu caráter nacional dado por um tratamento motívico e melódico que expressasse a alma do povo brasileiro. Por música popular, entretanto, os nacionalistas entendiam a música rural, folclórica, e a parcela da produção urbana ainda não deturpada pelas influências consideradas deletérias do urbanismo e do mercado cultural em formação. Assim, o choro e o samba "autêntico" poderiam entrar na composição desta música artística brasileira. 0 texto onde este projeto se encontra mais claramente definido e discutido em diversos aspectos é o Ensaio sobre a música brasileira, de Mário de Andrade, publicado em 1928. ${ }^{10}$

Considerando este projeto, aqui apenas esboçado em linhas muito gerais, é compreensível que gêneros musicais que estiveram nas origens da formação da música popular no Brasil - como a modinha e o lundu, num primeiro momento, e o choro, o maxixe, o tango brasileiro e as primeiras manifestações do samba carioca - além, é claro, do folclore rural, sempre tenham sido incluídos entre os objetos de estudo das linhas mais tradicionais da musicologia histórica no Brasil. E também se pode

${ }^{10}$ ANDRADE, Mario de. Ensaio sobre a música brasileira. São Paulo: I. Chiarato \& Cia., 1928. 
compreender por que a música popular urbana que surge a partir da década de 1930, em estreita ligação com o mercado de bens culturais, foi considerada pela musicologia, até pelo menos a década de 1980, como fora de sua área de interesse, indigna de estudos sérios.

É certo que existiram músicos que fizeram uma ponte entre a produção erudita e popular urbana, a exemplo de Radamés Gnattali. Mas foi apenas com a quebra da hegemonia do nacionalismo no campo da música artística no Brasil nos anos 1960, com a ação das vanguardas, especialmente dos compositores reunidos em torno do grupo Música Nova, e a vinculação de setores da intelectualidade com a música popular, que a musicologia começaria timidamente a tomar a sério a produção musical popular.

Desta forma, em que pese a incidência marcante da corrente nacionalista na musicologia brasileira ao longo do século XX, sua influência nos rumos da música popular urbana no Brasil não foi determinante e sua presença na historiografia e nos estudos musicais populares se dá de forma indireta. Se, para a música erudita, os escritos e elaborações de Mário de Andrade constituíram um programa que foi implementado na construção de uma escola de composição que se tornou hegemônica a partir da década de 1930 até meados dos anos 1960, na música popular urbana não podemos identificar no campo de produção nenhuma corrente que se possa considerar "andradeana". José Miguel Wisnik afirma que as ideias de Mário de Andrade deixaram marcas por vezes esmagadoras sobre pelo menos três gerações de compositores. ${ }^{11}$ Os compositores populares não sentiram esse peso. As marcas das ideias andradeanas foram esmagadoras só para a produção da chamada música erudita ou de concerto.

Mário de Andrade tem o mérito de se encontrar entre os primeiros intelectuais do país a se ocuparem da música popular, num momento em que, mesmo no plano internacional, esta não era objeto de estudo. ${ }^{12}$ Porém, é preciso ressaltar que a música urbana tem uma presença marginal em seus textos, pois o que ele chamava de música popular era algo diferente daquilo a que o conceito refere-se nos estudos atuais. Mário estava em busca da música folclórica, oriunda do meio rural, cujos elementos fossem tradicionais, autóctones, característicos do brasileiro, para alimentar a formação de

\footnotetext{
11 WISNIK, José Miguel. O coro dos contrários: música em torno da Semana de 22. 2aㅡ ed. São Paulo: Duas Cidades, 1983, p. 105

12 Geralmente são considerados como fundadores dos estudos sobre música popular os textos de Adorno, contemporâneos aos de Mário, extremamente críticos em relação ao objeto.
} 
uma música artística nacional. São frequentemente citadas passagens do texto $A$ música e a canção populares no Brasil,,13 a começar pela afirmação de que o estudo científico da música popular brasileira ainda estava por se fazer. Nesse texto, após discorrer sobre as especificidades da canção popular brasileira, decorrentes de sermos uma "nacionalidade de formação recente e não propriamente autóctone", o autor afirma que, embora seja de boa ciência afastar-se de qualquer colheita folclórica a documentação das grandes cidades, isso não se aplicaria no caso do Brasil, onde existia uma interpenetração do rural e do urbano. Mário reconhecia que existiam manifestações características de música popular brasileira que eram especificamente urbanas, como o choro e a modinha, mas estas teriam de ser separadas daquelas manifestações popularescas, feitas à feição do popular, ou influenciadas pelas modas internacionais.

Ao contrário do que ocorreu no campo de produção erudito, seus escritos não influenciaram os rumos da música popular no Brasil. Assim, é uma fina ironia da História para com o projeto andradeano que nossa música popular urbana tenha se constituído numa manifestação cultural associada à nossa identidade nacional, e que, a partir da década de 1960, tenha atingido internacionalmente o status de produto artístico, realizando assim, por vias tortas, a proposta da construção de uma música artística autenticamente brasileira. Mas, se suas elaborações não influenciaram os rumos da produção musical, o mesmo não se pode dizer em relação ao pensamento sobre esta produção, pois seus textos foram e ainda são considerados no debate. Diversos pesquisadores, entre os quais se destaca José Miguel Wisnik, fizeram uma ponte entre as idéias de Mário de Andrade e os estudos sobre a música popular.

$\mathrm{Na}$ medida em que a musicologia e a intelectualidade acadêmica se desinteressaram dos assuntos da música popular urbana, ao mesmo tempo em que esta se constituía como um fenômeno social de grande alcance, a construção da memória e as primeiras reflexões sobre esta música foram obra de jornalistas, cronistas e músicos ligados direta ou indiretamente ao próprio campo de produção.

Datam da década de 1930 os primeiros textos dedicados à construção de uma memória da música popular no Brasil, especialmente aquela feita no Rio de Janeiro. No

13 ANDRADE, Mário. Ensaio sobre a música brasileira. São Paulo: Livraria Martins, 1972, pp.163-167. 
ano de 1933 foram publicados dois textos fundadores de uma narrativa acerca do samba carioca: Na roda do samba, ${ }^{14}$ do jornalista Francisco Guimarães, conhecido como Vagalume, e Samba: sua história, seus poetas, seus músicos e seus cantores, ${ }^{15}$ de Orestes Barbosa. Em 1936 é lançado O choro: reminiscências dos chorões antigos, ${ }^{16}$ de Alexandre Gonçalves Pinto, conhecido como Animal, um inventário dos chorões do Rio de Janeiro de sua época, escrito num estilo simples de livro de memórias de personagens considerados relevantes na tradição do choro no Rio de Janeiro, que seria seguido por outros autores posteriores. É um caso um pouco à parte nesta linhagem de memorialistas que, em sua grande maioria, estavam inventando uma tradição da música brasileira na qual o centro e expressão máxima da musicalidade nacional era o samba carioca.

Os livros de Vagalume e Orestes Barbosa apresentam duas vertentes interpretativas para o surgimento daquela que seria considerada a autêntica música do Rio de Janeiro e, por extensão, considerada também a autêntica música brasileira, o samba. Segundo Marcos Napolitano,

O debate entre Guimarães e Barbosa pode ser visto como um termômetro das sensibilidades confusas e contraditórias a respeito do tema, uma "primeira camada" de representações acerca do universo social e estético da música popular brasileira, como, por exemplo, a relação entre "samba" e "morro", que se tornou um mito fundador da nossa identidade musical. Já naquela época, as discussões sobre a música popular se pautaram ora pela busca de uma "raiz" social e étnica específica (os negros), ora pela busca de um idioma musical universalizante (a nação brasileira), base de duas linhas mestras do debate historiográfico. ${ }^{17}$

Na narrativa de Vagalume, o samba nasceu na Bahia e de lá foi para o Rio, onde tomou vulto e desenvolveu-se até tornar-se predominante. 0 autor descreve um percurso para o samba, desde uma condição primitiva no sertão da Bahia até a constituição do samba carioca, do qual o autor faz a apologia. Este samba carioca seria,

\footnotetext{
14 GUIMARÃES, Francisco (Vagalume). Na roda de samba. RJ: MEC/FUNARTE, 1978. Primeira edição:

15 BARBOSA, Orestes. Samba: sua história, seus poetas, seus músicos e seus cantores. RJ: MEC/FUNARTE, 1978. Primeira edição:

16 PINTO, Alexandre Gonçalves (Animal). $O$ choro: reminiscências dos chorões antigos. RJ: MEC/FUNARTE, 1978. Fac-símile da primeira edição, de 1936.

17 NAPOLITANO, Marcos. A historiografia da música popular brasileira (1970-1990): síntese bibliográfica e desafios atuais da pesquisa histórica. In: ArtCultura. Uberlândia: EDUFU, v.8, noํ 13, 2006, p.136. Esta linha de pensamento está também desenvolvida em NAPOLITANO, Marcos; WASSERMAN, Maria Clara. Desde que o samba é samba: a questão das origens no debate historiográfico sobre a música popular brasileira. Revista Brasileira de História: São Paulo, v.20, no 39, p.167-189, 2000.
} 
em suas palavras, filho legítimo dos morros. Mas, na sua visão, se o samba nasceu no alto do morro e no coração do homem rude, o samba morre quando passa da boca da gente da roda, para o disco da vitrola. Ou seja, para o jornalista Vagalume, o samba autêntico tende a morrer quando estabelece relações com o mercado de bens culturais. Observe-se que o discurso não é uma crítica ao mercado do samba em si, até porque, como jornalista especializado, Vagalume fazia parte deste mercado em processo de estruturação. Sua crítica dirige-se contra práticas correntes que, em seu entender, descaracterizavam o samba autêntico, tradicional, aquele oriundo da roda do samba. Este posicionamento encerra uma contradição intrínseca - entre a pureza da autenticidade e as leis do mercado - que se reproduzirá sempre que se queira manter intacta uma determinada tradição e fazê-la circular amplamente através dos meios de comunicação massivos, ou seja, submeter o mercado aos interesses estéticos e sociais de um determinado setor.

O grande ícone da narrativa é Sinhô, mas também merecem destaque Caninha, Eduardo das Neves, Donga, Heitor dos Prazeres e Pixinguinha. Francisco Alves é muito citado, mas de um ponto de vista crítico. Curiosamente Noel Rosa, que seria apresentado como herói em narrativas posteriores, especialmente na de Almirante, sequer é mencionado por Vagalume: seu nome aparece apenas numa lista de sambas e marchas para o carnaval de 1933 como N. Rosa. 0 nome de Noel não aparece, mas não faltam menções desabonadoras da presença de poetas no samba, considerando que isso conduziria à decadência do gênero, propondo um samba sem gramática, que não desmentisse o seu passado. Vagalume, defensor do lugar social e das características poético-musicais que ele considerava como tradicionais, concluiu seu enaltecimento do samba com um programa e um apelo em defesa do gênero. Podemos então constatar que a defesa da autenticidade do samba já atuava em 1933 - e ainda se mantém em boa forma mais de 75 anos depois.

A narrativa de Orestes Barbosa, por outro lado, principia com a afirmação de que o samba é carioca e que nele a emoção da cidade está musical e poeticamente definida. Para o autor, o carioca seria diferente em tudo, de todos os povos, e, assim sendo, criou a sua música original. Orestes Barbosa, ao contrário de Vagalume, não se refere a uma rota do samba a partir da Bahia, nem ressalta a predominância da "roda" 
no surgimento de um autêntico samba carioca. Concorda com este que o samba nasce no morro, mas, para Barbosa, o samba é apropriado de diferentes maneiras pela cidade, sem que isto seja apresentado como um fato deplorável. Para o autor, já eram sambas os tangos de Ernesto Nazareth, assim como, por medo de se dizer o vocábulo, foram chamados de polca, lundu e maxixe todos os sambas do tempo do Imperador. Nazareth e Anacleto de Medeiros aparecem como precursores dessa música carioca e Sinhô como figura maior entre os sambistas já falecidos, mas sem o destaque que recebeu na narrativa de Vagalume. Segundo o autor, a música popular tomou incremento com os Oito Batutas, mas são citados inúmeros sambistas famosos do período, diluindo assim as glórias pela afirmação do gênero: Pixinguinha, Donga, Catulo, Eduardo das Neves, Francisco Alves, Mário Reis, Noel Rosa, Carmen Miranda, entre outros compositores, cantores e instrumentistas. 0 autor não faz a crítica da comercialização do samba, ao contrário, afirma que o samba tem no rádio um grande servidor. Percebe-se assim uma acepção mais ampla do gênero e uma concepção que não vê obstáculos nas relações com o mercado.

Ficam assim delineadas duas vertentes interpretativas que seriam linhas mestras na historiografia do samba. Uma narrativa é a de que foi nas rodas dos morros cariocas que o samba, vindo da Bahia, tomou a forma que se popularizou na cidade e, a partir daí, no resto do país. 0 crescimento e estruturação do mercado cultural seria uma ameaça para o samba que, sendo apropriado por outras camadas sociais, estaria se descaracterizando e perdendo sua razão de ser. Daí a necessidade de se defender e preservar o samba tradicional, autêntico. A outra interpretação vê o samba, ainda que tendo surgido no morro, como produto da cidade do Rio de Janeiro, da confluência de múltiplas informações culturais, uma síntese. 0 trânsito do samba por diversas camadas socioculturais, longe de constituir um problema, teria contribuído para a consagração do gênero. Apesar desta diferenciação e algumas outras nuanças, estas narrativas possuem uma grande concordância fundamental: fazem o enaltecimento, a apologia, a exaltação do samba, elegendo-o como a grande música popular brasileira.

Estes e outros textos de pessoas ligadas direta ou indiretamente ao meio musical popular - jornalistas, colecionadores, músicos e amadores - iniciaram uma literatura e uma reflexão sobre a música popular no Brasil, num momento em que os 
círculos mais eruditos estavam voltados para o projeto modernista, os estudos do folclore e a criação de uma música nacional artística e desinteressada, expressão utilizada por Mário de Andrade. Conforme afirma José Geraldo Vinci de Moraes, "a prática iniciada na geração de Vagalume permaneceu viva (com Jota Efegê, Almirante, Lúcio Rangel, entre outros), solidificou-se e desenvolveu-se nas décadas seguintes, formando destacado conjunto de acervos e análises da musica popular". 0 autor afirma que "sem eles, provavelmente a reconstrução de parte da cultura do país pela música seria muito mais complicada ou quase impossível, ainda que a maior parte dessa produção tenha sido assinalada pelo tom biográfico, impressionista e apologético, fundado em paradigma historiográfico tradicional". ${ }^{18}$ Vinci de Moraes chama de "primeira geração de historiadores da música popular urbana" esse grupo de pesquisadores nascidos entre o final do século XIX e as primeiras décadas do XX. Para ele, "esse conjunto de autores organizou um discurso histórico integral ao manipular todo o processo de operação historiográfica", no sentido que Michael de Certeau dá a essa expressão. Segundo Vinci de Moraes, eles definiram um lugar social, organizaram uma prática de análise e pesquisa e construíram uma narrativa, organizando assim um autêntico discurso historiográfico sobre a música popular no Brasil. ${ }^{19}$ A existência desta corrente historiográfica tem sido identificada por diversos autores, que a denominam de distintas maneiras. Enor Paiano ${ }^{20}$ e Clara Wasserman ${ }^{21}$, por exemplo, preferem chamá-los de folcloristas urbanos. Paulo Cesar Araujo ${ }^{22}$, de divulgadores da música popular.

Existem muitos pontos de contato entre este grupo e a escola do nacionalismo musical, como observa Enor Paiano. Segundo ele, ambos têm o mesmo espírito: a paixão pelas "coisas brasileiras", uma metodologia similar (recolher, organizar, compilar, mantendo a fidelidade à expressão original) e um nacionalismo de caráter protetor, visando impedir a deturpação da expressão nacional, seja pela

\footnotetext{
18 MORAES, José Geraldo Vinci de. História e historiadores da música popular urbana no Brasil. Comunicação apresentada no VI Congresso da IASPM-AL. Buenos Aires, 2005, p. 5.

19 Ibidem, p. 5-8

20 PAIANO, Enor. Berimbau e o som universal: lutas culturais e indústria fonográfica nos anos 60. Dissertação de mestrado em Comunicação. São Paulo: ECA-USP, 1994.

21 WASSERMAN, Maria Clara. Abre a cortina do passado: a Revista de Música Popular e o pensamento folclorista (Rio de Janeiro: 1954-1956). Dissertação de mestrado em História. Curitiba: UFPR, 2002.

22 ARAUJO, Paulo César de. Eu não sou cachorro não: memória da canção popular "cafona" (1968-1978). Dissertação de mestrado em Memória Social e Documento. Rio de Janeiro: UNIRIO, 1999.
} 
comercialização, seja pelas influências estrangeiras. A diferença principal, ainda segundo Paiano, é que esse grupo, que ele chama de folcloristas urbanos, não endossa o discurso modernista da superioridade artística da expressão erudita e, ao contrário do nacionalismo musical, que se aparelhou nos órgãos estatais e veículos dirigidos à intelectualidade, este grupo preferiu os meios de comunicação de massa para a veiculação de suas ideias e produções, fazendo com que estas tivessem divulgação mais ampla. ${ }^{23}$ A diferenciação entre estas correntes também é discutida por Napolitano e Wasserman. Para eles, "os autores preocupados com a questão da autenticidade do samba, não encontraram no pensamento musical de Mário de Andrade um apoio para estabelecer uma tradição reconhecível e legítima para a música urbana" na qual o samba fosse "o eixo central". Teria sido "esta lacuna no pensamento folclorista de Mário de Andrade que perturbou um conjunto de criadores musicais, radialistas e jornalistas cariocas", que, a partir do final dos anos 1940, "tomaram para si a tarefa de consolidar um pensamento historiográfico sistematizado em torno da música urbana" popular. ${ }^{24}$

Entre estes memorialistas, tem certo destaque a figura de Almirante (Henrique Foréis Domingues). Cantor e compositor, fundou em 1929 o Bando de Tangarás junto com Braguinha (João de Barro), Alvinho, Henrique Brito e Noel Rosa, cuja atividade musical acompanhou até o falecimento. Radialista, trabalhou em diversas emissoras a partir de 1935, produzindo programas sobre assuntos quase sempre ligados à música popular. Almirante reuniu contribuições que pedia aos ouvintes em seus programas e materiais que recolhia com apurado senso de organização, para constituir um arquivo pessoal respeitável. Após a morte de Noel Rosa, dedicou-se à construção da sua memória, realizando programas de rádio, artigos em periódicos e palestras sobre o compositor de Vila Isabel. Em 1963, publicou No tempo de Noel Rosa ${ }^{25}$, livro que sintetiza suas crônicas da vida de Noel, texto decisivo na invenção do mito que se formou em torno dele como herói máximo do panteão de gênios da música brasileira popular. Almirante costura uma ligação entre a música urbana, o samba, e o elemento folclórico, rural e sertanejo, entendido aqui não no sentido que o termo adquiriu nos nossos dias, mas como referência ao sertão nordestino. Destaca a figura do violonista

\footnotetext{
23 PAIANO, Enor. Op. cit., pp.68-69.

24 NAPOLITANO, Marcos; WASSERMAN, Maria Clara. Desde que o samba é samba: a questão das origens no debate historiográfico sobre a música popular brasileira. Revista Brasileira de História: São Paulo, v.20, no 39, 2000 , p.172.

25 ALMIRANTE (Henrique Foréis Domingues). No tempo de Noel Rosa. São Paulo: Francisco Alves, 1963.
} 
João Teixeira Guimarães, o João Pernambuco, e sua influência no interesse que as canções folclóricas nordestinas despertaram no Rio de Janeiro na primeira década do século XX. Essas canções também teriam entrado no caldo de cultura de informações rítmicas e melódicas que concorreram na gênese do samba. Constrói assim uma narrativa que vê o samba como uma música surgida na cidade do encontro de múltiplas sonoridades e influências culturais, canalizando elementos de tradição e autenticidade.

Em 1954, o jornalista Lúcio Rangel funda, juntamente com Pérsio de Moraes, a Revista da Música Popular, publicação periódica que circulou no Rio de Janeiro, entre agosto de 1954 e setembro de 1956, com 14 edições. ${ }^{26}$ A revista contou com a colaboração de nomes como Almirante, Ary Barroso, Fernando Lobo, Jorge Guinle, Mariza Lira, Nestor de Holanda, Sérgio Porto e Silvio Túlio Cardoso. Publicou ainda, postumamente, artigos e discursos de Mário de Andrade. A influência da revista excedeu sua curta existência, provavelmente determinada pela intransigência e o purismo de sua linha editorial e administrativa. Maria Clara Wasserman realizou um estudo do papel da revista como articuladora de um debate musical voltado para a divulgação massiva dos músicos populares que, para seus editores e colaboradores, representavam a tradição da música urbana brasileira. A autora cita os livros de Lúcio Rangel e de Almirante, Sambistas \& Chorões $^{27}$ e No tempo de Noel Rosa, respectivamente, como uma compilação do pensamento que norteou o periódico entre os anos de 1954 e 1956. E inclui Ary Vasconcelos, embora ele não tenha sido um membro da revista, mas um colaborador esporádico, como um dos herdeiros do pensamento crítico-musical da Revista de Música Popular. ${ }^{28}$

Na década de 1960, além dos citados No tempo de Noel Rosa, de Almirante e Sambista \& Chorões, de Lúcio Rangel, são publicados outros textos influentes e representativos desta linha de pensamento como as crônicas de Jota Efegê e o Panorama da Música Popular Brasileira ${ }^{29}$, de Ary Vasconcelos, além dos primeiros trabalhos de José Ramos Tinhorão.

\footnotetext{
26 REVISTA DA MÚSICA POPULAR. Coleção completa em fac-símile: setembro de 1954-setembro de 1956 . Rio de Janeiro: Bem-te-vi Produções Literárias/FUNARTE, 2006.

27 LÚCIO, Rangel. Sambistas \& chorões: aspectos e figuras da música popular brasileira. São Paulo: Francisco Alves, 1962.

28 WASSERMAN, Maria Clara. Abre a cortina do passado: a Revista de Música Popular e o pensamento folclorista (Rio de Janeiro: 1954-1956). Dissertação de mestrado em História. Universidade Federal do Paraná, Curitiba, 2002, pp. 9 e 117.

29 VASCONCELOS, Ary. Panorama da música popular brasileira. São Paulo: Martins, 1964.
} 
Personagem importante desta geração, o jornalista carioca João Gomes Ferreira, conhecido pelo acrônimo de Jota Efegê, teve seus artigos publicados em diversos jornais e revistas do Rio de Janeiro, a partir de 1940, reunidos pela FUNARTE em dois volumes intitulados Figuras e coisas da música popular brasileira ${ }^{30}$. A FUNARTE editou ainda mais um conjunto de crônicas de Jota Efegê reunidas no livro Meninos, eu $v i^{31}$, mas, nesse caso, o tema é a vida da cidade do Rio de Janeiro e seus personagens de uma forma mais ampla, onde a música, naturalmente, também está presente. Seus dois prefaciadores nesses livros, Ary Vasconcelos e Carlos Drummond de Andrade, ressaltam seu apuro de pesquisador diligente, sua honestidade e esmero na coleta de informações. Porém, como se tratam de crônicas escritas originariamente para jornais e revistas, elas estão marcadas pelo tom jornalístico, a narrativa está geralmente apoiada em memórias - do autor e de suas fontes - e o texto é apologético e laudatório em relação ao samba e seus heróis.

No Panorama da Música Popular Brasileira de Ary Vasconcelos encontra-se a periodização que se tornou clássica e muitas vezes citada em estudos sobre música popular. Inicialmente Ary Vasconcelos delimita as épocas de acordo com momentos da história política do país, o que reflete uma concepção antiga da historiografia da música no Brasil. Assim, para ele, existe uma música popular brasileira da Colônia, do Império e da República. Nessa obra o autor se atém ao período da República, que ele subdivide da seguinte maneira: 1) de 1889 a 1927, fase antiga, primitiva ou heróica; 2) de 1927 a 1946, fase de ouro; 3) de 1946 a 1958, fase moderna; 4) de 1958 em diante, fase contemporânea. Em Ary Vasconcelos já se encontra mais delineada a atuação de historiador em relação aos trabalhos anteriores desta corrente de pesquisadores. Em obras posteriores ele se propôs a dar conta das raízes da música popular no Brasil desde os primórdios, sem perder o foco central de suas pesquisas, que era a música urbana carioca, erigida à condição de música nacional. Ele preocupou-se com a preservação da memória nas suas discografias, biografias dos personagens, mas também encontramos mais atenção na citação das fontes de suas afirmações.

\footnotetext{
30 EFEGÊ, Jota. (João Gomes Ferreira). Figuras e coisas da música popular brasileira. Rio de Janeiro, FUNARTE, v.1, 1978; v.2, 1980. O primeiro volume, de 1978, reuniu crônicas publicadas entre 1940 e 1968 (e uma de 1975), e o segundo volume, lançado em 1980, reuniu textos de 1970 a 1978.

31 EFEGÊ, Jota. (João Gomes Ferreira). Meninos, eu vi. Rio de Janeiro: FUNARTE, 1985.
} 
Mas o principal personagem desta corrente historiográfica é José Ramos Tinhorão, que dá um passo além em relação aos pesquisadores que o antecederam na consolidação de uma narrativa para a história da música popular no Brasil, ao incorporar, além da pesquisa exaustiva e da constante citação de suas fontes, uma metodologia histórico-sociológica que orienta o seu trabalho desde os primeiros textos. Seus livros foram e ainda são influentes no debate sobre música popular e incluem-se entre aqueles trabalhos que foram seminais para as pesquisa acadêmicas.

\subsection{TINHORÃO: DE JORNALISTA POLÊMICO A HISTORIADOR DA MÚSICA POPULAR}

Os primeiros livros da vasta obra de Tinhorão, se já continham o programa que norteia seu pensamento explicitamente definido, tinham também um tom panfletário e de polêmica aberta, um caráter nitidamente militante e de intervenção, ao sabor de sua atividade de crítico musical na imprensa. ${ }^{32}$ Tratavam-se de textos escritos no calor da hora, num momento em que estava em curso a modernização da música popular brasileira, contra as expectativas e propostas do autor. É o caso de Música popular: um tema em debate 33 , lançado em 1966, livro que reuniu artigos polêmicos publicados em jornais e revistas entre 1961 e 1965. O artigo Os pais da bossa nova, por exemplo, classifica a bossa nova34 como "filha de aventuras secretas de apartamento com a música norte-americana", que seria sua mãe, sendo que não se sabe quem seria o pai, da mesma forma que ocorria com muitas crianças de Copacabana, bairro onde surgiu. Nesse texto Tinhorão lista os músicos e compositores que eram mencionados pela imprensa como precursores da bossa nova apresentando-os em termos depreciativos: Johnny Alf como mulato americanizado que disfarça seu nome verdadeiro João Alfredo; Tom Jobim como “compositor repetidamente acusado de apropriar-se de músicas norte-americanas", também com apelido americanizado; Baden Powell como acusado de ter se apropriado de temas folclóricos que divulga com o seu nome, derivado da

\footnotetext{
32 A atividade de Tinhorão como crítico musical do Jornal do Brasil em dois momentos distintos - a coluna semanal Primeiras lições de samba (1961-1962) e Música Popular (1974-1982) foi discutida em: LAMARÃO, Luisa Quarti. As muitas histórias da MPB: as idéias de José Ramos Tinhorão. Dissertação de mestrado em História. Niterói: UFF, 2008. 33 TINHORÃO, José Ramos. Música popular: um tema em debate. Rio de Janeiro: Editora Saga, 1966.

34 Este trabalho segue a nova ortografia da língua portuguesa, adotada a partir do acordo ortográfico assinado em 1990, e aprovado no Brasil em 1995. Entretanto, para os títulos e citações de obras, manteve-se as grafias originais. A única exceção foi "bossa nova", que na nova ortografia se escreveria hifenizado, "bossa-nova". Optei, neste caso, pela grafia antiga, por se tratar da uma denominação consagrada. Vamos ver como o tempo resolve esta questão.
} 
“admiração alienada do pai pelo general imperialista inglês criador do escotismo". E segue nessa linha. ${ }^{35}$

Em O samba agora vai: a farsa da música popular no exterior ${ }^{36}$, a polêmica já está no título. Tinhorão desenvolve uma linha de pensamento segundo a qual, a partir da conquista do mercado internacional pelo capital norte-americano após a Segunda Guerra, "todos os países foram progressivamente levados a sufocar" suas músicas populares fundadas nas tradições de seus povos, para moldar-se ao novo estilo da música comercial norte-americana. No caso do Brasil, esse "mecanismo de dominação cultural" teria gerado "uma intervenção contínua no processo evolutivo da música urbana, tornando-se mais forte à medida que a classe média foi apropriando-se dos gêneros criados pelas camadas populares", que se nutriam do material folclórico advindo do mundo rural. Passaram a existir então vários gêneros de música popular produzida nas cidades, para atender à diversidade de gostos das distintas camadas sociais urbanas. Para o autor, "como a camada capaz de importar ou de exportar música é sempre a classe média urbana", "foi sempre a música urbana produzida ao nível das camadas alfabetizadas que se procurou fazer representar no exterior como a 'verdadeira música popular brasileira'”. É a história dessa "farsa” que o autor se propõe a contar nesse livro, desde a ida de Domingos Caldas Barbosa a Portugal no século XVIII até o show da bossa nova no Carnegie Hall e seus desdobramentos, passando pelas incursões dos Oito Batutas e de Carmen Miranda, entre outros eventos. ${ }^{37}$ Nesta narrativa, todos, mesmo que com eventuais boas intenções, acabaram por apresentar nossa música descaracterizada para adaptar-se a padrões internacionais. Apesar de sermos informados na introdução que será historiado um conjunto de fatos com profusão de documentos, não é isso que se nota ao longo do texto, mais voltado para a defesa das posições do autor do que para a investigação histórica. ${ }^{38}$

Nestes dois livros já se encontravam esboçadas as idéias que Tinhorão desenvolveria ao longo de sua obra, mas tratam-se de textos polêmicos, de luta sem

\footnotetext{
35 TINHORÃO, José Ramos. Op. cit., pp. 25-26.

36 TINHORÃO, José Ramos. O samba agora vai. Rio de Janeiro: JCM Editores, 1969.

37 TINHORÃO, José Ramos. Op. Cit., pp.7-10.

38 Por exemplo, Tinhorão afirma que o relato mais fiel da apresentação da bossa nova no Carnegie Hall foi seguramente seu artigo publicado na revista O Cruzeiro, de 8 de dezembro de 1962, com o título Bossa Nova desafinou nos EUA, escrito com base em informações colhidas no local e enviadas em carta manuscrita pelo correspondente Orlando Suero. Op. cit., p. 106.
} 
quartel com intenção de incidir no rumo dos acontecimentos. A posição que estes textos reverberava foi derrotada no debate travado nos anos 1960 sobre os rumos que deveria tomar a música popular brasileira, na medida em que, ainda que com mediações, a atualização da música popular no Brasil e a incorporação de novas informações técnico-estéticas de fato se efetivou. ${ }^{39}$

Mas Tinhorão não se deu por vencido. Nunca reviu suas posições no debate dos anos 1960 e, ao longo de toda suas obra, buscou sustentá-las com uma argumentação fundamentada na sua pesquisa histórica, um amplo estudo da formação da música popular urbana no Brasil. Com a publicação de seu terceiro livro dedicado ao objeto, Música Popular: de índios, negros e mestiços ${ }^{40}$, o autor inicia uma pesquisa histórica bem estruturada, com projeto bem definido e diligente levantamento de dados e busca de novas fontes. Desde então, ampliou significativamente os temas de seu interesse, mergulhando em questões da longa duração, observando seu objeto sob distintos aspectos e abrindo novas frentes de pesquisa. Construiu, a partir deste texto, uma vasta obra historiográfica, de grande relevância para os estudos da música no Brasil. Tinhorão abordou temas como as relações da música popular com o teatro e o cinema, com os meios tecnológicos de produção e reprodução. Estudou a presença da música popular no romance brasileiro, a forma como os autores situaram em suas histórias tipos ou episódios ligados à música popular urbana. Discutiu também a música informal e anônima feita nas ruas, a trajetória dos sons dos negros no Brasil, o fado como música originalmente brasileira, entre outros temas. Em 1999, defendeu dissertação de mestrado em História Social na FFLCH-USP. Tornou-se, com o tempo, um importante historiador da música brasileira popular construindo uma obra de grande fôlego.

Ao longo do tempo, Tinhorão aprimorou sua metodologia de trabalho, mas manteve-se sempre fiel ao programa apresentado no prefácio de Música Popular: um tema em debate. Sua obra representa uma importante vertente na historiografia da música popular no Brasil e se tornaria uma referência para uma história da música no Brasil, especialmente para aquelas visões que se fundamentam numa leitura ortodoxa

\footnotetext{
39 Na introdução à 3a edição de Música popular: um tema em debate, de 1997, Tinhorão admite que "suas interpretações sócio-culturais vieram a cair no esquecimento desde a segunda edição do livro às vésperas de 1970". Afirma a seguir, bem ao seu estilo, que as conclusões do livro foram "sancionadas pela história dos fatos recentes da cultura de massas no Brasil, o que consagra de maneira definitiva a vitória de seu modelo de estudo pioneiro". (pp. 9-10)

40 TINHORÃO, José Ramos. Música popular: de índio, negros e mestiços. Petrópolis: Vozes, 1972.
} 
do materialismo histórico. 0 autor tem o mérito inegável de expor suas concepções com toda a clareza. Conforme sua linha de inspiração marxista, segundo a qual a base determina a superestrutura, para Tinhorão, numa sociedade de classes toda a cultura é uma cultura de classes. Existiria assim uma cultura das classes dominantes, geralmente chamadas de "elites", e uma cultura popular, entendida como cultura das camadas mais baixas da pirâmide social. As classes médias, dentro desta lógica, não conseguiriam jamais um caráter próprio dada a sua posição nas relações de produção. De fato, segundo as leituras mais ortodoxas do marxismo, a classe média não tem projeto político-econômico próprio: ou apoia a burguesia e o sistema capitalista ou coloca-se sob a liderança do proletariado em sua luta por uma sociedade sem classes. Com um determinismo histórico-sociológico claramente assumido, que considera a cultura como reflexo da estrutura da sociedade determinada pelo modo de produção, sua narrativa fica inteiramente direcionada por estes pressupostos.

No prefácio de Música Popular: um tema em debate, José Ramos Tinhorão faz, com a clareza e objetividade que caracterizam o seu texto, uma apresentação de seu programa de estudos. Vejamos, em suas palavras, a definição de seu projeto:

Pelos trabalhos deste livro, vai-se notar que o autor assume reacionariamente a defesa da cultura que melhor representa o estágio de semi-analfabetismo das camadas mais baixas da população, contra a pretendida "evolução" que alguns supõem resultar do encontro dessa cultura com a semi-erudita, ou mesmo erudita, atualmente ao alcance da classe média.

Coerente com o método de abordagem sociológica adotado na interpretação dos temas aqui em estudo, o autor explica sua posição intelectual com o fato de, no presente instante do desenvolvimento brasileiro, a cultura das camadas mais baixas representar valores permanentes e históricos (o latifúndio ainda não foi abolido), enquanto a cultura da classe média reflete valores transitórios e alienados (o desenvolvimento industrial ainda se submete a implicações do Capital estrangeiro).

Isso quer dizer que, enquanto o que se chama de "evolução", no campo da cultura, não representar uma alteração da estrutura sócio-econômica das camadas populares, o autor continuará a considerar autênticas as formas mais atrasadas (os sambas quadrados de Nelson Cavaquinho, por exemplo), e não autênticas as formas mais "adiantadas" (as requintadas harmonizações dos sambas bossa-nova, por exemplo). ${ }^{41}$

Na introdução de Cultura Popular: temas e questões ${ }^{42}$, Tinhorão reafirma as ideias que norteiam a construção de suas interpretações histórico-sociológicas. Para o autor, a divisão da sociedade em classes, decorrente do modo de produção capitalista preservado pelas instituições do estado moderno, faz com que os homens não

\footnotetext{
41 TINHORÃO, José Ramos. Música popular: um tema em debate. 3a ed. São Paulo: Editora 34, 1997, pp. 13-14.
}

42 TINHORÃO, José Ramos. Cultura popular: temas e questões. São Paulo: Editora 34, 2001. 
participem da sociedade como indivíduos, mas como membros de uma classe. Consequentemente, assumem as ideias e valores considerados próprios e bons para essa classe, o que constituiria uma ideologia, no sentido marxista do termo. Este princípio, transportado para o campo das criações alheias à produção material, como as manifestações artísticas, faz com que, no entender de Tinhorão, também esta produção projete uma ideologia. Como o modo de produção capitalista determina a divisão da sociedade em classes, toda a cultura seria então uma cultura de classes, raciocínio que encontra-se também na introdução da História social da música popular brasileira.

\footnotetext{
Como os fatos historiados no livro demonstram, essa diversidade cultural é normalmente simplificada através da divisão da cultura em apenas dois planos: o da cultura das elites detentoras do poder político-econômico e das diretrizes para os meios de comunicação - que é a cultura do dominador - e a cultura das camadas mais baixas do povo urbano e das áreas rurais, sem poder de decisão política - que é a cultura do dominado.

Acontece que nas nações em que a capacidade de decisão econômica não pertence inteiramente aos detentores políticos do Poder, como é o caso de países de economia capitalista dependente - e entre eles o Brasil em estudo -, a própria cultura dominante revela-se uma cultura dominada. ${ }^{43}$
}

Note-se que a cultura das camadas pobres teria ainda que enfrentar, além da concorrência da cultura da elite, também a da classe média, que, consumidora dos produtos da indústria cultural e ligada a modelos estéticos importados, nas palavras de Tinhorão, identifica-se mais com as elites do que com o povo. Nesta linha de raciocínio, a cultura das camadas mais baixas fica submetida a uma dupla dominação: em relação à cultura das elites dirigentes do país e em relação à matriz estrangeira que domina essa cultura. Em outras palavras, a cultura das elites dominantes do país é, por sua vez, dominada por uma cultura alienígena. Em última instância, o problema da cultura seria um problema político e a única alternativa para se escapar desta agressão cultural seria a luta insurrecional contra a dominação das elites e de libertação nacional para enfrentar a reação estrangeira que tal mudança estrutural acarretaria. ${ }^{44}$

Apoiado neste instrumental teórico, Tinhorão chegou a conclusões bastante desfavoráveis em relação a toda produção musical que não fosse aquela que se desenvolvesse como expressão das camadas mais baixas da população e que estivesse

\footnotetext{
43 TINHORÃO, José Ramos. História social da música popular brasileira. São Paulo: Editora 34, 1998, p.10.

44 Ibidem, pp. 9-13.
} 
supostamente isenta de interferências da cultura dos países economicamente mais desenvolvidos.

Tinhorão foi se tornando cada vez mais respeitado na medida em que seus estudos foram ficando mais analíticos e mais consistentes em relação a dados. A polêmica sempre acompanhou a sua obra, mas num tom diferente daquele dos primeiros anos. No próximo capítulo, dedicado ao ensaísmo acadêmico dos anos 1970 e 1980, veremos o contraponto aos escritos de Tinhorão nos anos 1960, representado fundamentalmente pelo livro $O$ balanço da bossa. ${ }^{45}$ De toda forma, a partir dos anos 1970 os textos de Tinhorão irão se constituir em parte fundamental deste esforço de pensar a história da música popular no Brasil e sua obra, ao lado dos trabalhos de José Miguel Wisnik e Arnaldo Contier, em perspectivas distintas, foi um dos fundamentos para a historiografia acadêmica da música popular que iria se desenvolver a partir da década de 1980.

Pode-se discordar das proposições de José Ramos Tinhorão, mas sua obra continua sendo referência nos estudos sobre a música popular e tem de ser considerada no debate, quaisquer que sejam as opiniões que se possa ter sobre seus pressupostos estético-ideológicos. Registre-se também que o autor possui um estilo literário refinado, o que torna sua leitura bastante agradável. Ainda que seus textos não sejam acadêmicos stricto sensu, ou seja, não são parte da produção da Universidade, são acadêmicos no sentido lato, na forma e no conteúdo.

\subsection{A DEFESA DA TRADIÇÃO NA MÚSICA POPULAR BRASILEIRA}

Os discursos destes memorialistas, jornalistas e primeiros historiadores da música popular no Brasil, abordados neste capítulo, tiveram importância decisiva na construção de um pensamento sobre a canção popular brasileira fortemente ancorado na ideia de um momento áureo da nossa música, quando teria se expressado de maneira autêntica a alma de amplas camadas da base da pirâmide social e construído um patrimônio cultural a ser preservado das influências estrangeiras, dos interesses do mercado e dos modismos alienados da classe média. De um modo geral, estes discursos

45 CAMPOS, Augusto de. Balanço da bossa. São Paulo: Perspectiva, 1968. 
se relacionam com as discussões em torno do nacional e do popular, tão presentes no Brasil entre as décadas de 1920 e 1960, com reverberações até nossos dias. A invenção de uma tradição na música popular se insere em toda uma operação de invenção de uma identidade nacional que está fora do escopo deste trabalho analisar.

Em torno de uma linhagem da música popular no Brasil que tem como eixo central o samba carioca, articulou-se um conjunto de produtores musicais, um público, divulgadores, jornalistas, relações com a indústria e o mercado e um pensamento histórico-sociológico, que podemos pensar como um sistema que envolvia autores, obras, público, intérpretes, mercado e divulgadores, utilizando aqui, de maneira flexibilizada, a terminologia de Antonio Candido. ${ }^{46}$

Para desgosto dos puristas radicais para os quais qualquer transformação no samba cristalizado no tempo e no espaço (o Rio de Janeiro da década de 1930) constitui um crime de lesa-cultura nacional, a partir da institucionalização da MPB no final dos anos 1960, constituiu uma linha formativa que articula três gêneros - samba, bossa nova e MPB - que passaram genericamente a se incluir sob o guarda-chuva da sigla MPB, como a tradição da música popular brasileira "de qualidade". Este processo formativo está estudado no trabalho de diversos autores, entre os quais Marcos Napolitano e Sean Struod. ${ }^{47}$ A ideia desta linhagem como articuladora da tradição da música popular brasileira foi dominante no pensamento sobre esta música até por volta dos anos 1980 e, mesmo que perdendo força, até hoje constituí um dos parâmetros para o debate sobre a produção e recepção da música no Brasil. Um conjunto de mediadores culturais - entre intelectuais, produtores musicais, músicos, jornalistas e aficionados - foi determinante para a construção desta noção de MPB à

\footnotetext{
46 Em seu estudo sobre a formação da literatura brasileira, Antonio Candido distingue "manifestações literárias" de literatura propriamente dita, entendendo esta como "um sistema de obras ligadas por denominadores comuns, que permitem reconhecer as notas dominantes duma fase. Estes denominadores são, além das características internas (língua, temas, imagens), certos elementos de natureza social e psíquica, embora, literariamente organizados, que se manifestam historicamente e que fazem da literatura aspecto orgânico da civilização". Entre estes elementos Antonio Candido distingue: a existência de um conjunto de produtores literários, um conjunto de receptores e um mecanismo transmissor que liga uns aos outros. 0 conjunto destes elementos dá lugar a um tipo de comunicação que se constitui como sistema simbólico. 0 processo formativo seria aquele no qual a atividade dos escritores se integra em tal sistema articulado. Nesta tese os termos sistema e formação aparecem dentro desta perspectiva, utilizados de maneira flexível tendo em vista as características específicas do objeto em questão. CANDIDO, Antonio. Formação da literatura brasileira: momentos decisivos 1750-1880. 12ª ed. São Paulo/Rio de Janeiro: FAPESP/Ouro sobre azul, 2009. Primeira publicação em 1957.

47 NAPOLITANO, Marcos. A Síncope das idéias: a questão da tradição na música popular brasileira. São Paulo: Editora Fundação Perseu Abramo, 2007; STROUD, Sean. Disco é Cultura: MPB and the defence of tradition in Brazilian popular music. Tese de PhD. University of London, 2005. Publicada como: The defense of tradition in Brazilian popular music: politics, culture and the creation of Música Popular Brasileira. Hampshire: Ashgate Publ., 2007.
} 
qual se agrega a defesa de uma tradição musical que deve ser preservada como símbolo da brasilidade. Stroud demonstra a atuação destes mediadores, entre os quais inclui o Estado através da atuação da FUNARTE. No caso deste estudo bibliográfico, é importante atentarmos para o papel das publicações da FUNARTE na construção de uma memória e da história da música no Brasil.

A Fundação Nacional da Arte (FUNARTE) foi criada em 1975 como parte de um conjunto de iniciativas do governo Geisel (1974-1979) em direção à promoção da cultura nacional, numa iniciativa política voltada para uma tentativa de aproximação com artistas, intelectuais e setores da classe média insatisfeitos com o regime militar. Uma vez criado esse espaço institucional, sua atuação no terreno da música popular esteve diretamente influenciada pelas proposições apresentadas pela corrente de jornalistas e pesquisadores da música popular abordados neste capítulo. Estes estudiosos tinham inclusive recém se organizado na Associação de Pesquisadores da Música Popular Brasileira (APMPB) ${ }^{48}$, entidade fundada em 1975, que contou com nomes como Tinhorão, Ary Vasconcellos, Sérgio Cabral, Roberto Moura, Ruy Castro, Zuza Homem de Mello entre outros.

Durante as décadas de 1970 e 1980 a Fundação Nacional de Arte (FUNARTE) relançou os livros clássicos de Francisco Guimarães (Vagalume) ${ }^{49}$, Orestes Barbosa ${ }^{50}$ e Alexandre Gonçalves Pinto (Animal) ${ }^{51}$, publicou as crônicas de Jota Efegê52 e diversas biografias de músicos ou personagens ligados à música popular, como Chiquinha Gonzaga ${ }^{53}$, Pixinguinha ${ }^{54}$, Ary Barroso ${ }^{55}$, Geraldo Pereira ${ }^{56}$, João Pernambuco57,

\footnotetext{
48 A Associação de Pesquisadores da Música Popular Brasileira (APMPB) foi fundada no primeiro Encontro de Pesquisadores da Música Popular Brasileira realizado em Curitiba em 1975. Seu 2o Encontro foi realizado no ano seguinte no Rio de Janeiro, com o apoio da FUNARTE e do MEC. Outros encontros aconteceram em 1982, 1985 e o último deles em 2001. Segundo Sean Stroud, a APMPB, através de seus encontros e dos escritos de seus associados, atuou como um grupo de pressão, alertando o governo contra o que eles entendiam serem ameaças à brasilidade na música popular. Sua influência, através da atuação de seus associados, também pode ser identificada em alguns projetos governamentais, como a Política Nacional de Cultura de 1975, o Projeto Pixinguinha e as edições da FUNARTE recém comentadas. Entretanto, sua atuação foi bastante irregular e esporádica enquanto entidade organizada, ainda que seus encontros tenha oferecido algumas das raras oportunidades de reunir escritores, acadêmicos, jornalistas, pesquisadores e músicos para discutir questões relacionadas ao campo da musica popular. (STROUD. Op. cit.,pp.54-59)

49 GUIMARÃES, Francisco (Vagalume). Na roda de samba. Rio de Janeiro: FUNARTE, 1978.

50 BARBOSA, Orestes. Samba: sua história, seus poetas, seus músicos e seus cantores. Rio de Janeiro: FUNARTE, 1978.

51 PINTO, Alexandre Gonçalves (Animal). 0 choro: reminiscências dos chorões antigos. Fac-símile da edição de 1936. Rio de Janeiro: FUNARTE, 1978.

52 EFEGÊ, Jota. (João Gomes Ferreira). Figuras e coisas da música popular brasileira. Rio de Janeiro, FUNARTE, v.1 1978, v.2 1980.

53 LIRA, Mariza. Chiquinha Gonzaga: grande compositora brasileira. 2ª ed. Rio de Janeiro: FUNARTE, 1978.

54 CABRAL, Sérgio. Pixinguinha: vida e obra. Rio de Janeiro: FUNARTE, 1978; SILVA, Marília T. Barbosa da; OLIVEIRA FILHO, Arthur L. de. Pixinguinha: filho de ogum bexiguento. Rio de Janeiro, FUNARTE, 1979.
} 
Custódio Mesquita ${ }^{58}$, Tia Ciata ${ }^{59}$, entre outros. Também foram publicados diversos estudos do folclore e cultura brasileira, entre os quais se destacam textos de Edison Carneiro $^{60}$, Luís da Câmara Cascudo ${ }^{61}$ e Renato Almeida ${ }^{62}$, além de partituras de músicas de concerto esteticamente afiliadas ao nacionalismo musical. Em 1977 a FUNARTE dá início ao Projeto Pixinguinha idealizado por Hermínio Bello de Carvalho, que, em sucessivas edições de concertos a preços populares, alcançou grandes públicos por todo o Brasil, oferecendo uma música identificada com uma certa linhagem da música popular brasileira tida como "música de qualidade". Todas estas iniciativas estavam vinculadas à ideia da preservação e divulgação das "coisas brasileiras". 63

\footnotetext{
55 MORAES, Mario. Recordações de Ary Barroso. Rio de Janeiro: FUNARTE, 1979.

56 CAMPOS. Alice Duarte Silva de. Um certo Geraldo Pereira. Rio de Janeiro: FUNARTE, 1983.

57 LEAL, José de Souza. João Pernambuco: a arte de um povo. Rio de Janeiro: FUNARTE, 1982.

58 GOMES, Bruno. Custódio Mesquita: prazer em conhecê-lo. Rio de Janeiro: FUNARTE, 1986.

59 MOURA, Roberto. Tia Ciata e a pequena África no Rio de Janeiro. Rio de Janeiro: FUNARTE, 1983.

60 CARNEIRO, Edison. Capoeira. Rio de Janeiro: FUNARTE, 1975.

${ }^{61}$ CASCUDO, Luís da Câmara. Mitos brasileiros. Rio de Janeiro: FUNARTE, 1976.

62 ALMEIDA, Renato. Folclore. Rio de Janeiro: FUNARTE, 1976.

63 STROUD, Sean. The defense of tradition in Brazilian popular music: politics, culture and the creation of Música

Popular Brasileira. Hampshire: Ashgate Publishing Group, 2007.
} 


\title{
CAPÍTULO 2 \\ O ENSAIO ACADÊMICO: MOMENTO FORMATIVO DE UM CAMPO DE ESTUDOS. FUNDAMENTOS PARA A HISTORIOGRAFIA
}

\begin{abstract}
A julgar pelos artigos histéricos reunidos em livro pelo senhor José Ramos Tinhorão - infelizmente o único a colocar o assunto música popular brasileira em discussão - somente a preservação do analfabetismo asseguraria a possibilidade de se fazer música no Brasil. Embora assim não esteja explícito em palavras no livro, a atuação dos artistas da classe média é (se levarmos até o fim esse raciocínio) apenas um acidente nefasto: não houvesse ocorrido isso e o futuro nos asseguraria pobres autênticos cantando sambas autênticos, enquanto classe-médias estudiosos, como o senhor Tinhorão, aprenderiam os nomes das notas. Restando apenas saber para que aprendê-los. ${ }^{64}$
\end{abstract}

O texto acima é a frase de abertura de um artigo de Caetano Veloso, de polêmica com o livro Música popular: um tema em debate. 0 autor ressalta que a polêmica com o livro de Tinhorão estava motivada não apenas por ser ele o único livro, até aquele momento, a colocar o tema em debate; partia também da certeza de que ele representava a sistematização de uma tendência equivocada da inteligência brasileira com relação à música popular. Caetano critica, ao longo do texto, o que considerava um discurso antimoderno em defesa da autenticidade. Argumenta que, se acompanharmos a evolução do samba até onde nos agrada ou interessa e o cristalizarmos num momento que nos pareça definitivo, podemos, por exemplo, nos ater ao samba de roda da Bahia e renegar até o mais primitivo partido-alto carioca. ${ }^{65}$ Nas discussões que se desenvolveram nas décadas seguintes, e que ainda reverberam, esta seria uma linha de argumentação fundamental contra os discursos em defesa das ideias de "autenticidade" e de "raiz" cristalizadas no samba carioca da década de 1930.

Se este artigo apareceu num veículo de circulação restrita, teve maior repercussão a participação de Caetano no debate promovido e publicado pela Revista de Civilização Brasileira em 1966, intitulado Que caminhos seguir na música popular

\footnotetext{
64 VELOSO, Caetano. Primeira feira de balanço. In: SALOMÃO, Waly (org.). Alegria, alegria. Rio de Janeiro: Pedra \& Ronca, 1977. Texto publicado originalmente na revista Ângulos, da Faculdade de Direito da UFBA, 1966, p.1.

65 Idem., p.3 . Em entrevista a Luis Antônio Giron na revista Época (GIRON, 2005), Caetano comenta a respeito desse texto: "Eu já tinha um lance pop tropicalista no próprio título, inspirado no anúncio de uma grande loja de departamentos em Salvador que liquidava para balanço. Foi uma utilização ready-made. Eu estudava na Faculdade de Filosofia quando alguém me pediu um artigo para a revista Ângulos, da Faculdade de Direito. A esquerda estava entusiasmada com o Tinhorão, que apoiava a xenofobia. Embora eu falasse naquele tempo mal do rock e da Jovem Guarda, o gérmen tropicalista estava ali."
} 
brasileira? ${ }^{66} \mathrm{Na}$ sua intervenção Caetano Veloso apresenta a ideia da linha evolutiva, que já estava esboçada em Primeira feira de balanço, como uma alternativa para se resistir ao tradicionalismo no estilo de Tinhorão sem cair em "uma modernidade de ideia ou de forma imposta como melhoramento qualitativo". ${ }^{67}$ A proposta da "retomada da linha evolutiva" era a de, partindo da compreensão do que foi a música popular brasileira até aquele momento, estabelecer "uma possibilidade seletiva como base de criação". Nesse entendimento, para se fazer algo novo dentro da tradição, dar um passo à frente, era necessário conhecê-la e senti-la. Assim, a proposta não era de ruptura com a tradição, mas de continuidade evolutiva: e como João Gilberto era, nesse entendimento, quem melhor tinha utilizado a informação da modernidade na recriação e na renovação musical, a retomada da linha evolutiva deveria se dar a partir de sua obra. Esta ideia de linha evolutiva da música popular brasileira tornou-se tanto uma proposta de atuação artística com desdobramentos práticos imediatos na tropicália, como uma leitura do que tinha sido até então a corrente principal da música popular urbana no Brasil. Esta proposição tem de ser entendida no contexto das discussões estéticas em curso, e como tal, um argumento a favor da modernização e incorporação de novas informações na música brasileira popular como uma continuidade da tradição. Naturalmente implica numa visão evolutiva e numa certa seleção do repertório, numa certa linhagem da tradição, que deve ser submetida à crítica, especialmente se esta proposição for tomada como referência para se pensar a história da música popular. Ou seja, ainda que tenha servido de argumentação para se contrapor às correntes mais conservadoras que refutavam qualquer alteração na linguagem, a proposição da linha evolutiva caminha no sentido da construção de uma certa linhagem oriunda do samba como sendo a música popular brasileira, questão que estará em foco em diversos momentos deste trabalho. ${ }^{68}$

\footnotetext{
66 REVISTA DE CIVILIZAÇÃo BRASILEIRA. Que caminho seguir na música popular brasileira? Ano I, no 7, maio de 1966. Curiosamente, o debate é anunciado da seguinte maneira: "Em virtude da crise atual da música popular brasileira, a Revista de Civilização Brasileira, reuniu músicos, compositores, intelectuais e estudiosos da música popular para um debate sobre os caminhos da música popular brasileira [...]".

67 Ibidem, p.378.

${ }^{68}$ A proposição da linha evolutiva motivou debates no plano das ideias, com manifestações no próprio campo de produção. Em As Aventuras de Raul Seixas na cidade de Thor, do LP Gita, 1974, Raul Seixas coloca-se, de maneira bem humorada, fora da linha evolutiva: / Acredite que eu não tenho nada a ver com a linha evolutiva da música popular brasileira / A única linha que eu conheço é a linha de empinar uma bandeira /.
} 
O mais influente dos textos em defesa da incorporação de novas informações em nossa música popular e contra as ideias nacionalistas de autenticidade foi o livro $O$ Balanço da Bossa, organizado por Augusto de Campos. Lançado em 1968, o volume reunia artigos do musicólogo Brasil Rocha Brito (o mais antigo, publicado em 1960 no jornal Correio Paulistano), do maestro Júlio Medaglia e do compositor Gilberto Mendes além dos textos do próprio Augusto de Campos. Todos estes autores pertencentes ao campo de produção erudito, mas entusiastas da música popular, "interessados numa visão evolutiva da música popular, especialmente voltados para os caminhos imprevisíveis da invenção"69, como podemos ler na introdução. Augusto de Campos, seu irmão Haroldo de Campos e Décio Pignatari formavam o grupo de poetas concretistas, que, juntamente com intelectuais de outras áreas, especialmente músicos como Rogério Duprat, Júlio Medaglia e Gilberto Mendes, tinham a perspectiva de uma produção artística de vanguarda cujo alcance rompesse o círculo restrito da arte no Brasil. Estavam sintonizados com a produção da vanguarda internacional na música e na literatura, bem como pensavam as novas questões colocadas pelo desenvolvimento da comunicação massiva. A interação de jovens músicos paulistas interessados nas linguagens da vanguarda musical - que conheceram diretamente nos festivais de Darmstadt - com as proposições dos poetas concretistas esteve nas origens das concepções estéticas e da poética musical do grupo Música Nova, um dos marcos da renovação da linguagem musical no Brasil. ${ }^{70}$

Por volta de 1968, quando o Balanço da Bossa foi publicado, os irmãos Campos já tinham reconhecimento internacional, haviam publicado poemas, escritos teóricos e traduções de Ezra Pound e Vladimir Maiakovski, além do Panorama do Finnegans Wake $^{71}$, tradução de 16 fragmentos do livro de James Joyce e estudos sobre a obra considerada um marco da literatura moderna, um trabalho muito útil para uma

\footnotetext{
${ }^{69}$ CAMPOS, Augusto de. Balanço da bossa. 5a ed., 1 a reimpressão. São Paulo: Perspectiva, 2003, p.14.

70 O grupo Música Nova constituiu-se em 1961 após a VI Bienal de Arte de São Paulo, quando os compositores Gilberto Mendes, Willy Corrêa de Oliveira, Rogério Duprat e Damiano Cozzela tiveram suas obras executadas no mesmo concerto. 0 grupo formaliza sua existência com um manifesto publicado em 1963, assinado pelos quatro compositores citados mais Régis Duprat, Júlio Medaglia, Sandino Hohagen e Alexandre Pascoal. O Música Nova foi um importante marco na renovação da linguagem musical no Brasil, até então hegemonizada pela estética do nacionalismo. As proposições dos poetas concretistas influenciaram diretamente a formação do tropicalismo, no qual Rogério Duprat e Júlio Medaglia tiveram importante participação como arranjadores. Sobre o grupo Música Nova ver NEVES, José Maria. Música Contemporânea Brasileira. São Paulo: Ricordi Brasiliera, 1981, e ZERON, Carlos Alberto de Moura Ribeiro. Fundamentos histórico-políticos da música nova e da música engajada no Brasil a partir de 1962: o salto do tigre de papel. Tese de doutorado. FFLCH-USP, 1991.

${ }^{71}$ CAMPOS, Augusto de; CAMPOS, Haroldo de. Panorama do Finnegans Wake. 4⿳ạ ed. São Paulo: Perspectiva, 2001.
} 
primeira abordagem de um livro extremamente difícil de ser lido e compreendido. Um exemplo desta sintonia com as questões teóricas colocadas pela arte de vanguarda é o fato de Haroldo de Campos ter antecipado, num artigo de 1958, questões que seriam estudadas por Umberto Eco em seu aclamado livro Obra Aberta. Escreveu Eco na introdução à edição brasileira:

É mesmo curioso que, alguns anos antes de eu escrever Obra Aberta, Haroldo de Campos, num pequeno artigo, lhe antecipasse os temas de modo assombroso, como se ele tivesse resenhado o livro que eu ainda não tinha escrito, e que iria escrever sem ter lido seu artigo. Mas isso significa que certos problemas se manifestam de maneira imperiosa num dado momento histórico, deduzem-se quase que automaticamente do estado das pesquisas em curso. ${ }^{72}$

Também as questões da relação com o mercado eram enfrentadas pelos poetas concretistas. Décio Pignatari cunhou a expressão produssumo para designar uma arte ao mesmo tempo de produção e de consumo. Os concretistas procuraram infiltrar sua produção no mundo da comunicação de massa através de processos visuais, ligados às técnicas contemporâneas de publicidade, das manchetes de jornal às histórias em quadrinhos. A incursão destes autores no universo da moderna música urbana não apenas emprestava legitimidade ao objeto, ao inserir no debate um grupo de artistas eruditos, mas colocava a discussão sobre a música popular num patamar mais elevado do que aquele por ela até então ocupado. Entretanto, assim como os livros de Tinhorão, o Balanço da Bossa era assumidamente uma peça de intervenção.

Estou consciente de que o resultado é um livro parcial, de partido, polêmico. Contra. Definitivamente contra a Tradicional Família Musical. Contra o nacionalismo-nacionalóide em música. 0 nacionalismo em escala regional ou hemisférica, sempre alienante. Por uma música nacional universal.

Não contra a Velha Guarda. Noel Rosa e Mário Reis estão mais próximos de João Gilberto do que supõe a TFM. Contra os velhaguardiões de túmulos e tabus, idólatras dos tempos idos.73

\footnotetext{
72 ECO, Umberto. Obra Aberta. 9ạ ed. São Paulo: Perspectiva, 2007, p. 17.

73 CAMPOS, Augusto de. Opus. cit., p.14-15. Aqui há um jogo de palavras com a sigla TFP, da Sociedade Brasileira de Defesa da Tradição, Família e Propriedade. Esta instituição representava um setor conservador e de direita da ortodoxia católica, tinha sido atuante em campanhas contra as reformas de base do governo João Goulart e se incluía entre os apoiadores do golpe militar de 1964. Existente até hoje, perdeu a visibilidade social conquistada nos anos 1960 pelo seu radicalismo após divisões motivadas por diferenças acerca de como se reposicionar perante as mudanças de orientação da Igreja Católica a partir do pontificado de João Paulo II.
} 
O artigo de Brasil Rocha Brito, o primeiro dos "balanços da bossa nova”, escrito em 1960, em pleno curso dos acontecimentos, apresenta, num pequeno ensaio, muitas pistas para uma abordagem musicológica da música popular. Após breve menção às influências e aos precursores, o autor faz uma análise da concepção musical da bossa nova na qual aborda a posição estética e as características gerais da estruturação do material musical e da interpretação. 0 autor ainda se ocupa das inovações no texto literário. 0 resultado é um trabalho de análise muito clarividente para um fenômeno ainda em curso, mais equilibrado do que análises impressionistas posteriores que enfatizam a "complexidade harmônica". Também os artigos de Júlio Medaglia e de Gilberto Mendes oferecem contribuições à análise musicológica, como as transcrições das inovações rítmicas. Mendes transcreve para a notação musical a "batida" de violão de João Gilberto e apresenta variações correntes, ressaltando a preponderância de dimensões ternárias contra a divisão binária em frases de dois compassos com dezesseis pulsos ou de um compasso com oito pulsos. Interessante a observação de que muitos confundiam esse tratamento rítmico com rumba, que caminha na direção da existência de uma matriz comum para a música popular surgida nas Américas. É possível fazer um paralelo entre estas transcrições e os time-lines da música africana que seriam utilizados para se pensar a rítmica na música brasileira nas pesquisas de Kazadi Wa Mukuna ${ }^{74}$ e Carlos Sandroni75, entre outros. As pistas para estudos musicológicos da música popular, oferecidas nestes textos, não tiveram continuidade, e a área de Música só iria abraçar o objeto a partir dos anos 1990.

Os textos de Augusto de Campos assumem a defesa da produção tropicalista e a ideia da retomada da linha evolutiva proposta por Caetano Veloso. No artigo mais teórico e analítico da obra, Informação e redundância na música popular, o autor traça um panorama das inovações musicais desde a bossa nova até o momento da redação. Segundo Campos, o be-bop e a bossa nova foram revoluções musicais que, pela própria natureza de suas inovações, só sensibilizaram um auditório restrito: foram os Beatles que conseguiram um salto qualitativo na questão da informação nova em música

\footnotetext{
${ }^{74}$ MUKUNA, Kazadi Wa. O contato musical transatlântico: contribuição Bantu na música popular brasileira. Tese de doutorado em Sociologia, FFLCH-USP, 1977.

75 SANDRONI, Carlos. Feitiço decente: transformações no samba no Rio de Janeiro (1917-1933). Rio de Janeiro: Zahar, 2001.
} 
popular em estreita relação com o consumo. No Brasil, na visão de Campos, teria havido um momento de desorientação após o sucesso da bossa nova, agravado pela situação política pós 1964, com uma onda de protesto e de Nordeste nas canções. Este teria sido um período de estagnação do ponto de vista da sintaxe musical, mas de enriquecimento semântico, na medida em que a temática amor-dor-flor do primeiro momento bossanovista estava esgotada. 0 advento da jovem guarda desloca temporariamente o debate entre velha guarda e bossa nova para outro debate, entre jovem guarda e música popular brasileira. Os nacionalóides, no dizer de Campos, perdida a primeira batalha, encontraram nos adeptos do então chamado iê-iê-iê "um prato mais suculento", pois se tratava de adversário desvinculado da tradição da música brasileira. E Chico Buarque, "na sua indecisão entre Noel e João Gilberto", pagou o seu "tributo à redundância", comemorado precipitadamente pelo que ele chamava ironicamente de TFM. Esse seria, no olhar de Augusto de Campos, o cenário do momento em que se daria "a retomada da linha evolutiva" da música popular brasileira a partir de João Gilberto. Caetano Veloso, Gilberto Gil e o grupo baiano estariam travando uma batalha por "uma 'abertura' na música popular brasileira", pondo "em xeque e em confronto, criticamente, o legado da bossa nova" e a "contribuição renovadora dos Beatles", operando "uma revolução nas leis da redundância" vigentes na música popular. ${ }^{76}$

Os autores dos artigos presentes no Balanço da Bossa apresentam nuanças na interpretação dos eventos em curso, por exemplo, em relação ao papel da jovem guarda. Os textos de Augusto de Campos têm uma visão mais positiva do iê-iê-iê à brasileira do que os de Gilberto Mendes e Júlio Medaglia, talvez ainda influenciados pelos parâmetros de sua formação musical erudita. Medaglia chega a afirmar que a sensibilidade popular europeia é pesada e que "lá só triunfam as manifestações musicais que se baseiam no estardalhaço, no grito, nas letras, nas melodias, nas harmonias, nos ritmos mais primitivos", bem como "os ídolos da juventude, que têm nos Beatles sua expressão máxima, atiram-se no chão com guitarras e microfones, emitem os mais incríveis ruídos, deixam crescer os cabelos e promovem outros e semelhantes escândalos para se fazerem perceber pela massa". ${ }^{77}$ Mas Medaglia foi mais condescendente com a versão brasileira mais bem comportada do iê-iê-iê e, assim

\footnotetext{
${ }^{76}$ CAMPOS, Augusto de. Opus. cit., pp. 179-188.

77 Ibidem, p.105.
} 
como Augusto de Campos no ensaio Da Jovem Guarda a João Gilberto, afirma que as interpretações de Roberto Carlos aproximavam-se mais de João Gilberto "do que os gorjeios dos que se pretendem sucessores do 'bossanovismo'”. ${ }^{78}$

O artigo de Medaglia intitulado Balanço da Bossa Nova é o mais abrangente e eclético de todos como afirma Campos na Introdução. 0 autor principia com uma tipologia da música popular que em linhas gerais, poderia ser dividida em três tipos preponderantes: a folclórica e a urbana subdividida em dois tipos: aquela que tem raízes na imaginação popular e é aproveitada e divulgada pelos meios de comunicação e aquela que já surge na indústria. 0 autor trabalhava com uma concepção de música popular como manifestação musical não erudita, daí a inclusão da música folclórica em sua tipologia, definindo-a da seguinte maneira: "liga-se mais diretamente a determinadas situações sociológicas, históricas e geográficas, congregando em sua estrutura uma série de elementos básicos que a tornam característica de uma época, uma região e até mesmo de uma maneira de viver". ${ }^{79}$ Está claro o que o autor quis dizer, mas, curiosamente, depois de anos de pesquisas nos quais muitos eventos musicais e socioculturais se sucederam, os pesquisadores da música popular urbana estão chegando a um entendimento acerca das características de seu objeto no qual se poderia tranquilamente incluir estes elementos utilizados por Medaglia para a definição de música folclórica. Por outro lado, sabemos também ser problemática essa divisão feita entre as músicas urbanas que nascem de raízes populares e as que nascem na indústria, embora certamente esta tese tenha ainda muitos apoiadores. De toda forma, esta tipologia é ilustrativa de um momento de formatação de um objeto de estudo.

Apesar destas nuanças, estes textos, além de estarem afinados por uma perspectiva evolutiva e de invenção na música popular, têm, em geral, as mesmas referências teóricas. De uma maneira geral, todos trabalham com as elaborações da Teoria da Informação, então em voga. Campos cita, como referência, uma análise de Abraham Moles acerca da contribuição das máquinas eletrônicas e eletroacústicas à sensibilidade musical, estudo da relação entre informação e redundância na mensagem artística. Outra referência importante são os trabalhos de Umberto Eco, especialmente

\footnotetext{
78 CAMPOS, Augusto de. Op. cit.., 120.

${ }^{79}$ Ibidem, p. 67.
} 
o livro Obra Aberta, já mencionado. Também são citados Marshall McLuhan e Ezra Pound. Deste último, tem destaque a famosa classificação dos poetas e escritores em seis categorias, muitas vezes utilizada para a classificação dos artistas em geral: inventores, mestres, diluidores, bons escritores sem maiores qualidades, beletristas e lançadores de moda. ${ }^{80}$ Para a discussão em questão, são utilizadas apenas as categorias de inventores e mestres. Observe-se que estes autores estão entre os principais referenciais das primeiras pesquisas acadêmicas, especialmente aquelas que buscavam alternativas a Adorno, que sequer é mencionado no Balanço. Podemos especular que alguns destes primeiros pesquisadores teriam sido remetidos para esses referenciais pela leitura do Balanço da Bossa.

Os primeiros livros de Tinhorão e o Balanço da Bossa, textos de polêmica e de intervenção escritos no curso dos acontecimentos, já apresentavam em linhas gerais as duas principais vertentes de pensamento que se desenvolveriam nas primeiras pesquisas acadêmicas sobre música popular no Brasil: observar o fenômeno partindo de uma análise marxista ortodoxa da sociedade ou buscar referências no instrumental teórico que vinha se desenvolvendo para o estudo dos novos fenômenos culturais massivos do século XX. Também alguns temas e posturas estéticas começaram a ficar delineados, como o estudo do samba, a defesa da autenticidade e a valorização da tradição da música popular brasileira, por um lado, e a perspectiva da modernização, da incorporação de novas tendências estéticas sem preocupações xenófobas nacionalistas, por outro.

Estes textos sintetizam a polarização das posições estéticas em jogo, mas durante a segunda metade da década de 1960, especialmente entre 1967 e 1968, diversas manifestações na grande imprensa e outros canais de comunicação colocaram intelectuais e produtores musicais no debate, com artigos publicados em veículos como

\footnotetext{
80 Em $A B C$ da Literatura, Ezra Pound classificou os escritores em seis categorias assim sumariadas por Augusto de Campos: "1. Inventores. Homens que descobriram um novo processo, ou cuja obra nos dá o primeiro exemplo conhecido de um processo; 2. Mestres. Homens que combinaram um certo número de tais processos e que os usaram tão bem ou melhor que os inventores; 3. Diluidores. Homens que vieram depois das duas primeiras espécies de escritor e não foram capazes de realizar tão bem o trabalho; 4. Bons escritores sem qualidades salientes (a classe que produz a maior parte do que se escreve) Homens que fazem mais ou menos boa obra em mais ou menos bom estilo do período (...) 5. Belles Lettres. Os que realmente não inventam nada, mas se especializam numa parte particular da arte de escrever; 6. Lançadores de modas. Aqueles cuja onda se mantém por alguns séculos ou algumas décadas e de repente entra em recesso, deixando as coisas como estavam." Esta formulação de Pound foi muitas vezes estendida para os artistas em geral. CAMPOS, Augusto. As Antenas de Ezra Pound. In: POUND, Ezra. ABC da Literatura. 11 $1^{\mathrm{a}}$ ed. São Paulo: Cultrix, 2006, p.10-11.
} 
o Suplemento Literário do jornal O Estado de S. Paulo ${ }^{81}$, Caderno B do Jornal do Brasil, a Revista Civilização Brasileira ${ }^{82}$, jornais Correio da Manhã, O Pasquim, entre outros. ${ }^{83} \mathrm{Um}$ dos textos de maior repercussão neste período, também com caráter de intervenção no curso dos eventos, foi o artigo de Walnice Nogueira Galvão, MMPB: uma análise ideológica ${ }^{84}$, no qual ela critica a ideia do "dia em que virá” presente nas letras de canções da Moderna Música Popular Brasileira (MMPB), e propõe um discurso no sentido de atuação concreta para a transformação da realidade, como ocorreria, por exemplo, em Pra não dizer que não falei das flores, de Geraldo Vandré. Neste artigo, Galvão apresenta a percepção de que estava se conformando um subgênero dentro da música popular, que viria a ser identificado pela sigla MPB, caracterizado por uma intencionalidade informativa e participante, com um compromisso no plano literário de interpretação da realidade social brasileira, identificada como música de qualidade e dentro da tradição da música popular brasileira, direcionada para uma faixa de público universitário e intelectualizada.

Com o endurecimento da ditadura militar a partir da edição do AI-5 no final de 1968, o recrudescimento da repressão política e cultural e a ida dos principais personagens da cena musical para o exterior, ocorreu um arrefecimento das tensões no campo da música popular. A nova conjuntura política estabelecida a partir de dezembro de 1968 mudou a agenda política da esquerda e de todos os setores que se opunham ao regime militar. Como resultado das lutas estético-políticas dos anos 1960 - que iniciam no final de 1958 com o surgimento da bossa nova e arrefecem em 1969 com a mudança da conjuntura política - a MPB consolidaria sua posição no cenário cultural brasileiro. Mais do que uma abreviatura para a expressão música popular

\footnotetext{
81 O Suplemento Literário do jornal O Estado de São Paulo circulou aos sábados entre 1956 a 1974 a partir de projeto elaborado por Antonio Candido, que indicou para seu editor Décio de Almeida Prado. Escreveram em suas páginas grandes nomes da intelectualidade brasileira, e a publicação tem relevância na história da imprensa no Brasil. Na recente reforma editorial do jornal, implantada em 14 de março de 2010, o novo caderno Sabático tenta recuperar de maneira atualizada o perfil do antigo Suplemento Literário, que de certa forma tinha se diluído no caderno Cultura.

82 A Revista Civilização Brasileira, editada pela Editora Civilização Brasileira, circulou de 1965 a 1968, quando foi fechada com a promulgação do AI-5, veículo no qual escreveram intelectuais de renome nacional e internacional.

83 Entre artigos publicados em 1968, podemos mencionar: Tropicalismo! Tropicalismo! Abre a as asas sobre nós!, de Affonso Romano de Sant'Anna; o ensaio de Roberto Schwarz, Notas sobre vanguarda e conformismo, de 1967, estudo crítico sobre a tropicália, republicado em $O$ pai de família e outros estudos, no qual constava também o ensaio Cultura e política, 1964-1969; Nem toda loucura é burra, nem toda lucidez é velha, de Chico Buarque de Hollanda; O universalismo e a $M P B$, de Sidney Miller; O trópico entrópico da tropicália, de Mário Chamie; O contexto tropicalista, de O. C. Louzada Filho, entre outros.

84 GALVÃO, Walnice Nogueira. MMPB, uma análise ideológica. In Saco de gatos: ensaios críticos. São Paulo, Livraria Duas Cidades, 1976, pp. 93-119. Publicado originalmente em 1968. Publicado originalmente na revista Aparte, nํ2, maio-junho, 1968.
} 
brasileira, a MPB tinha incorporado uma carga estética e ideológica em seu perfil e se transformaria numa "instituição sociocultural", conforme a expressão de Marcos Napolitano. ${ }^{85}$ A música popular conquistou, neste processo, um status social de produto artístico, de parte da cultura brasileira a ser valorizada e de objeto passível de estudos sérios.

\subsection{ANOS 70: ENSAIOS MENOS POLÊMICOS E MAIS ANALÍTICOS. A FORMATAÇÃO DE UM OBJETO DE ESTUDO.}

Os textos produzidos na década de 1970, tantos os ensaios como as primeiras dissertações na pós-graduação, já não estavam tão diretamente voltados para a polêmica, ainda que possamos localizar ecos das lutas dos anos 1960. De um modo geral, o ensaísmo da década de 1970 e início dos anos 1980 teve caráter mais analítico, direcionado para a formatação de um objeto de estudo e a construção de uma metodologia para abordá-lo. Da mesma forma que nos anos 1960, foi marcante, nesta literatura, a presença do pensamento político de esquerda. Mas, neste caso, como reflexão acerca dos processos político-sociais, seja sobre os acontecimentos recentes ou sobre a história político-cultural do país.

A mudança da conjuntura política no final da década de 1960, com a supressão das liberdades democráticas e dos direitos civis que ainda vigoravam após o golpe de estado de 1964, levou uma parcela da esquerda organizada a partir para o enfrentamento direto da ditadura através da luta armada. Mas a enorme desproporção de poderio militar entre as forças armadas e as organizações de esquerda, somado ao apoio que o regime tinha conquistado entre a população com o chamado "milagre econômico" e ao controle dos meios de comunicação, permitiu ao governo uma vitória esmagadora sobre as investidas guerrilheiras no Brasil. Uma vez descartada a via do enfrentamento direto ao governo militar através da luta armada e com os duros golpes que uma esquerda dividida sofreu com a brutal repressão do regime, o caminho que se apresentou foi o de uma resistência política. Os setores identificados com o pensamento de esquerda, organizados em algum agrupamento político ou não,

85 NAPOLITANO, Marcos. O “conceito” de MPB nos anos 60. In: História: questões \& debates. Curitiba, PR: Editora da UFPR, ano 16, n. 1, 1999, pág. 13 a 30. 
buscaram ganhar a luta ideológica na sociedade e tomaram parte em iniciativas pela redemocratização do país, ao mesmo tempo em que se organizavam e acumulavam forças para os movimentos de massa que tiveram um grande impulso nas manifestações estudantis de 1977, que seriam seguidas por grandes greves de trabalhadores na virada dos anos 1980. Assim, o momento político marcado pelo regime militar e a reorganização do movimento estudantil em torno da luta por liberdades democráticas favoreciam o discurso político de esquerda no ambiente universitário e, de certa forma, para a questão em estudo nesta tese, uma leitura da história da música popular de um ponto de vista de resistência cultural de setores explorados e oprimidos, ou diretamente de luta de classes.

O ensaísmo acadêmico dos anos 1970 e parte dos anos 1980 e sua inflexão analítica e reflexiva em relação aos textos da década anterior precisam ser contextualizado tanto nesta conjuntura política, quanto como decorrência de um período de efervescência cultural que colocou a canção popular brasileira como objeto estético num patamar superior. Com a expressão ensaísmo acadêmico refiro-me tanto aos ensaios propriamente ditos (realizados por autores acadêmicos ou não, mas com refinamento metodológico e de pesquisa) como às primeiras dissertações e teses realizadas na pós-graduação, que serão abordadas no próximo item. De um modo geral, esta produção intelectual desenvolveu-se inicialmente nas áreas de estudos literários e sociologia, em grande parte ancorada na análise do discurso das letras da canções. Como exemplo deste ensaísmo sobre música popular nos anos 1970, irei discutir a seguir quatro textos fundamentais do período: o livro Música Popular e Moderna Poesia Brasileira $^{86}$, de Affonso Romano de Sant'Anna, que estuda as relações entre música popular e poesia literária; Música popular: de olho na fresta ${ }^{87}$, de Gilberto Vasconcellos, estudo sociológico da linguagem da MPB no contexto da censura do regime militar; Samba, o dono do corpo $^{88}$, de Muniz Sodré, que apresenta a idéia do samba como resistência cultural negra; e o artigo de José de Souza Martins, Música sertaneja: a dissimulação na linguagem dos humilhados ${ }^{89}$, estudo sociológico da música sertaneja de

86 SANT'ANNA, Affonso Romano de. Música Popular e Moderna Poesia Brasileira. 4aa ed. São Paulo: Editora Landmark, 2004. 1a ed. Petrópolis: Vozes, 1977.

87 VASCONCELLOS, Gilberto. Música popular: de olho na fresta. Rio de Janeiro, Graal, 1977.

88 SODRÉ, Muniz. Samba: o dono do corpo. 2ª ed.. Rio de Janeiro: Mauad, 1998.

89 MARTINS, José de Souza. Capitalismo e tradicionalismo: estudo sobre as contradições da sociedade agrária no Brasil. São Paulo: Pioneira, 1975, pp. 103-161. 
então como manifestação cultural urbana decorrente da dinâmica da luta de classes. Estes textos encontram-se entre as principais referências para as primeiras pesquisas, são representativos das linhas de pensamento que vinham se desenvolvendo, e contribuíram para a legitimação da música popular como objeto digno de estudos no campo acadêmico. Os textos de José Miguel Wisnik e Arnaldo Contier, pela importância que têm como fundamentos para a historiografia, serão discutidos em item à parte.

Em meados da segunda metade dos anos 1970 é editado Música popular e moderna poesia brasileira ${ }^{90}$, livro de autoria de Affonso Romano de Sant'Anna, reunindo artigos e ensaios publicados ou apresentados em seminários a partir de 1968. Os textos de Sant'Anna foram contemporâneos dos primeiros estudos realizados na pós-graduação no Rio de Janeiro abordando relações entre texto literário e música popular, uma linha de pesquisa que então se iniciava ${ }^{91}$, mas, dentro dessa linha, foi o texto mais influente e profícuo em elementos para a pesquisa. 0 autor afirma na introdução que o objetivo do livro é fornecer, tanto a alunos e professores quanto a compositores e letristas, uma introdução à poesia moderna brasileira e suas relações com a música popular, uma introdução pedagógica ao assunto. Ou seja, Sant'Anna tinha claramente a intenção de incentivar e incidir sobre uma pesquisa que recém se iniciava. Em inúmeras passagens do livro encontramos sugestões de temas de pesquisa e considerações sobre caminhos que essa pesquisa teria de percorrer. E, nesse intento, foi muito bem sucedido. Na Nova Introdução à 4⿳亠丷a edição, o autor reconhece que nestes quase trinta anos "o livro teve várias edições, foi adotado, serviu de base para pesquisas". 92

Sant'Anna alerta ainda que não se trata de um livro de história no sentido convencional e faz algumas ressalvas, entre elas a de que muitos nomes deixaram de ser citados em função das intenções específicas do trabalho. Mas, de toda a forma, mesmo considerando-se todas essas ressalvas, não deixa de se constituir também num livro de história, que constrói uma narrativa, senão da história da música popular no

\footnotetext{
${ }^{90} \mathrm{Na}$ folha de rosto da $1^{\text {a }}$ edição consta 1978; na ficha catalográfica, 1977; a data da Introdução é 1976, que é a data que Sant'Anna toma como referência na Nova Introdução na 4⿳a edição.

910 primeiro deles a dissertação de mestrado de Anazildo Vasconcelos da Silva, A Expressão subjetiva como fundamento da significação na poesia de Chico Buarque, defendida em 1973, na PUC-Rio, sob a orientação de Afrânio Coutinho.

92 SANT'ANNA, Affonso Romano de. Música popular e moderna poesia brasileira. 4⿳亠丷a ed. São Paulo: Editora Landmark, 2004, pp. 7-8. 1aㅡ ed. Petrópolis: Vozes, 1977.
} 
Brasil, ao menos dos autores e canções que ofereceram mais elementos para uma análise comparativa com a poesia literária. Apontou diálogos entre poesia e letra de música e situou uma vertente da música popular dentro de uma história do modernismo no Brasil, concorrendo assim para a fixação de uma visão do passado, especialmente num momento em que a qualidade do texto literário das canções era um dos elementos de sua valorização como produto artístico. Esta questão da seleção do material estará presente na maioria dos trabalhos que, tendo por metodologia a análise da letra das canções, discutem suas relações com o contexto social. Por outro lado, a questão do texto musical e sua interação com o texto literário não é abordada. É uma análise "sem som", a letra das canções tomada como poesia. Entretanto, é preciso lembrar que este e outros trabalhos contemporâneos eram estudos pioneiros. A Musicologia demoraria muito mais que a área de Letras para se dar conta de que estava aí um objeto de estudo pertinente, que oferecia muitos elementos para pesquisa, que poderia e deveria ser estudado sem que isso desmerecesse o pesquisador.

O texto Tropicalismo! Tropicalismo! Abre as asas sobre nós, escrito em 1968, aborda o tropicalismo como um movimento artístico mais amplo, dentro do qual as manifestações musicais seriam apenas uma parte e assim não dá destaque especial a esta produção. Sant'Anna considerava o tropicalismo confuso, mas autêntico e jovem. Parece que o autor via o movimento com uma organicidade e perspectivas que ele não tinha, em ascensão e arregimentando jovens. E, ressaltando muitas vezes o aspecto de deboche das diversas produções tropicalistas e do Manifesto Antropófago de Oswald de Andrade, o artigo também adquire um tom de deboche não disfarçado. É um texto mais de comentários do que de análise propriamente dita, e hoje, com o distanciamento temporal, podemos ver que não foi perspicaz em captar o que o tropicalismo tinha de essencialmente positivo. De toda forma, deve-se ter em conta que este também foi um texto escrito no calor da hora: foi escrito em 1968, e ainda se inseria no espírito mais polêmico que analítico que caracterizava os escritos do momento. Mas, de uma maneira geral, ao longo de todo o livro, pode-se perceber um esforço de isenção do autor na narrativa de eventos e polêmicas, algumas das quais - entre as correntes poéticas - ele era participante. Entretanto, em algumas passagens, as concepções do autor acabam 
"vazando" na sua narrativa histórica, especialmente na adjetivação ao falar dos concretistas.

Sant'Anna apresentou cinco proposições em forma de teses nas quais expôs sua visão das relações entre poesia e música popular desde o momento do modernismo em 1922 até a constituição da letra da música popular num objeto de interesse para estudos literários na década de 1970. Estas proposições constituem uma narrativa histórica, que apresentarei de maneira resumida no parágrafo seguinte, articulando algumas frases fundamentais de seu discurso:

O modernismo de 1922 "não chegou a se interessar pela música popular" e "a atividade de Noel Rosa, por exemplo, aparece nos estudos da época "desvinculada dos acontecimentos dentro da série literária". Embora se possam estabelecer paralelos e relações cronológicas entre distintos momentos da série literária e da música popular, "somente com a criação da Revista da Música Popular", "com a passagem de Vinícius de Moraes para a série musical e o surgimento da bossa nova é que se observaria uma ligação mais sistemática entre música popular e poesia 'literária'”. Este momento encerraria "um período de equivalências entre música e poesia, para iniciar-se a fase das identidades". A bossa nova "seria a elaboração de um produto mais sofisticado" musical e literariamente, apresentando um depuramento formal "que a aproxima das correntes de vanguarda iniciadas em 1956 na série literária”. Na década de 1960 teria ocorrido uma convergência de linguagens entre cinema, teatro, artes plásticas, literatura e música. "Com o tropicalismo e a canção de protesto fixam-se entre outros nomes, Caetano Veloso e Chico Buarque". O tropicalismo "procura um elo entre os modernistas de 1922, passando pelas vanguardas de 1956". "A partir de 1968 no Brasil e no mundo, os movimentos estudantis de protesto chegam ao auge e entram em decadência por motivos históricos". "A uma música tropical e solar sobrevêm uma música e uma literatura underground, mais mórbida, esotérica, penumbrista e decadentista em que não faltam os orientalismos hippies". "Toda essa evolução marca, no entanto, uma crescente transformação da música popular brasileira num fenômeno não apenas sonoro, mas num produto escrito", transformando aquilo "que era inicialmente apenas voz". "Críticos e professores universitários começam a se interessar pela letra da música popular, surgindo daí uma ensaística a ela dedicada”. 
"Com isto, estende-se não apenas o conceito de música popular, mas o de literatura e, consequentemente, o de interpretação do texto". ${ }^{93}$

Para Sant'Anna, a música popular capitalizou a perplexidade do povo brasileiro ante o momento político pós-64 e passou a cumprir um papel que a poesia literária não poderia desempenhar, atraindo a atenção e a participação dos poetas de diversas maneiras. Nesse momento as escolas e universidades descobrem o texto da música popular como um produto a ser esteticamente analisado:

Os textos de música popular brasileira passaram a ser estudados rotineira-
mente nos cursos de literatura de nossas Faculdades de Letras. Isto se deve a
uma expansão da área de interesse dos professores e alunos, e a uma
confluência entre música e poesia que cada vez mais se acentua desde que
poetas como Vinícius de Moraes voltaram-se com força total para a música
popular e que autores como Caetano e Chico se impregnaram de literatura. ${ }^{94}$

As primeiras dissertações de mestrado sobre música popular são mais ou menos contemporâneas de Música Popular e Moderna Poesia Brasileira. Mas, nesse momento, as letras das canções populares já eram utilizadas nas escolas secundárias e nos cursos superiores de Letras, sendo esta a porta de entrada da música popular na Universidade brasileira. Podemos mesmo imaginar que as primeiras pesquisas na pósgraduação na área de Letras nesta linha de pesquisa que toma a letra das canções como um texto para estudos literários foram realizadas por estudantes que tiveram essa abertura para o estudo desse objeto nas aulas de graduação. O livro de Affonso Romano de Sant'Anna sistematizou e deu um fundamento histórico e teórico para uma ideia que estava no ar naquele período, manifesta em artigos de jornais, entrevistas e debates, que se expressava na frase "a música popular é a poesia cantada", $n$ vezes repetida e que até hoje faz parte de um certo senso comum intelectualizado. Não apenas influenciou na formatação de um objeto de estudo e de um caminho metodológico para abordá-lo, mas contribuiu também no processo de legitimação desse objeto dentro do campo científico, apresentando argumentos que valorizavam a música popular como objeto de pesquisa. Entretanto, já continha também o germe de problemas que iriam se apresentar nos estudos literários da música popular, como parte do processo de

\footnotetext{
93 SANT'ANNA, Affonso Romano de. Música popular e moderna poesia brasileira. Petrópolis: Vozes, 1977, pp.119-120.

${ }^{94}$ Ibidem, p.99.
} 
construção de metodologias para a abordagem do objeto: o texto literário é estudado desvinculado do texto musical e a narrativa histórica privilegia os autores e canções que apresentam mais elementos para a análise literária.

Também em 1977, foi publicado o livro de Gilberto Vasconcellos, Música popular: de olho na fresta ${ }^{95}$, coletânea de ensaios do autor publicados entre 1975 e 1977, que incluem também um artigo conjunto com Matinas Suzuki Jr., A musa popular brasileira (da bossa-nova à cantiga de roda) e o texto de introdução Fazendo perguntas com o martelo, de Silviano Santiago. 0 ensaio Tropicalismo: a propósito da geléia geral, insere-se no modelo de pesquisas que estava sendo desenvolvido na área de Letras, baseado no texto das canções, neste caso com uma reflexão sociológica sobre a cultura brasileira e também com um pouco mais de atenção para os aspectos sonoros. Já o ensaio De olho na fresta e o livro todo, de um modo geral, consagraram a expressão linguagem da fresta, que seria utilizada muitas vezes para se referir ao discurso subliminar presente em muitas das canções do campo da MPB, que, com o objetivo de driblar a censura, disfarçava a crítica ao regime militar com figuras de linguagem que deveriam ser decodificadas pelo ouvinte. A apresentação do livro começa assim:

Estes ensaios estão cifrados numa linguagem oblíqua, que se tornou
obrigatória hoje em dia na imprensa crítica: a linguagem da fresta, a única
talvez que consegue driblar a censura. Esses artigos mantêm afinidade afetiva
e eletiva com o seu objeto: a canção popular, a qual se viu obrigada a se valer
(como toda produção cultural brasileira) da mesma linguagem.
Tal ardil, é claro, tem um preço: elipses constrangidas, psius que passam
despercebidos, forçados eufemismos e uma manhosa sinonímia que às vezes
deixa o recado truncado; em suma, o risco da fresta não ser descodificada -
pelo leitor. Mas à mudez, voluntária ou involuntária, é preferível o verbo
engasgado; à cegueira, a esperança (mínima que seja) de um favinho de luz. De
olho na fresta. Resolvi assim deixar intacta a redação original. Um documento
a mais da aborrecida época que estamos vivendo. ${ }^{96}$

Em sua abordagem da música popular nos anos 1970, em $O$ minuto e o milênio, escrevendo no curso dos acontecimentos, José Miguel Wisnik tem, no livro de Gilberto Vasconcelos, uma de suas referências. A partir da proposição de uma tradição na música popular de contrapor à ordem repressiva um "contradiscurso", mesmo que

\footnotetext{
95 VASCONCELLOS, Gilberto. Música popular: de olho na fresta. Rio de Janeiro, Graal, 1977.

96 Ibidem, p. V.
} 
cifrado, Wisnik vai se inspirar no conto $O$ recado do morro, de Guimarães Rosa, para cunhar a expressão rede de recados.

A música popular é uma rede de recados, onde o conceitual é apenas um dos seus movimentos: o da subida à superfície. A base é uma só, e está enraizada na cultura popular: a simpatia anímica, a adesão profunda às pulsações telúricas, corporais , sociais que vão se tornando linguagem.

Na conjuntura de repressão dos anos 70 , a música popular desses poetas portadores do recado compreendeu talvez mais do que nunca a especificidade da sua força, e ela vem do prazer, diz a Festa imodesta, de Caetano, e da força indomável, diz O que será (A flor da pele/À flor da terra), de Chico Buarque. ${ }^{97}$

Esta proposição da rede de recados complementa a de linguagem da fresta e se tornaram categorias centrais para analisar a relação entre música, poesia e política nos anos 1970, ainda que a formulação de Wisnik não se atenha exclusivamente à mensagem inscrita na letra da canção, como se depreende da citação acima, na qual está incorporada a concepção de que a música apela ao corpo e às emoções fisicamente manifestas.

Uma das vertentes temáticas da época estava em entender os eventos recentes, como os textos recém-citados (os trabalhos de Wisnik serão discutidos em item à parte); outra vertente era voltada para o estudo do samba, sua origem e aspectos socioculturais. Ambas vertentes tinham um forte apelo político e podem ser pensadas como uma forma de se posicionar ideologicamente no contexto do regime militar, ou refletir sobre a história do país desde uma perspectiva de luta social, num momento em que a sociedade brasileira estava num acúmulo de forças e fazia os primeiros ensaios das manifestações pela redemocratização do país.

Já no final da década de 1970, quando algumas pesquisas em torno de objetos relacionados ao samba haviam sido realizadas no Rio de Janeiro, é publicado o livro de Muniz Sodré, Samba, o dono do corpo $^{98}$, que inspirou trabalhos posteriores oferecendo argumentos em defesa da ideia do samba como resistência cultural negra. Sodré procura indicar "como um aspecto da cultura negra encontrou em seu próprio sistema

\footnotetext{
97 WISNIK, José Miguel. O minuto ou o milênio ou por favor professor, uma década de cada vez. 0 texto foi escrito originalmente para o volume Música (em colaboração com Ana Maria Bahiana e Margarida Autran) da coleção Anos 70, publicada pela editora Europa, 1979. Encontra-se em Dança dramática (poesia / música brasileira). Tese de doutorado em Letras. São Paulo: FFLCH-USP, 1979 e Sem receita: ensaios e canções. São Paulo: Publifolha, 2004.

98 SODRÉ, Muniz. Samba: o dono do corpo. 2ª ed.. Rio de Janeiro: Mauad, 1998. Primeira edição: Codecri, 1979. Conforme Sodré afirma no prefácio à $2^{\text {a }}$ edição, as entrevistas que constituem o apêndice (Donga, Pixinguinha, Heitor dos Prazeres, Ismael Silva e Almirante) haviam sido publicadas na revista Manchete, dez anos antes da $1^{\underline{a}}$ edição.
} 
recursos de afirmação"99 dessa identidade étnica. E se propõe a dar conta dessa tarefa evitando o que ele chama de "reduções acadêmicas, procurando antes localizar na própria cultura negra as fontes geradoras de significação para o samba".100 Aqui encontramos explicitado o paradoxo que estaria presente em muitos dos primeiros trabalhos acadêmicos sobre a música popular, que é o discurso que questiona a objetividade das Ciências Humanas. Nessa linha de pensamento a música popular não poderia ser estudada dentro dos padrões de cientificidade estabelecidos. Vejamos como isso aparece em Muniz Sodré:

As abordagens acadêmicas para os fenômenos culturais originários das classes subalternas se apóiam sempre em uma dessas posições que, como todo empreendimento científico, se esforçam para aperfeiçoar a sua racionalidade positiva, separando cada vez mais sujeito e objeto do conhecimento.

A sociedade ocidental parece não se fatigar de produzir círculos viciosos: primeiro abole o sentido de totalidade dos vínculos sociais e depois se põe a inventar ciências humanas que expliquem as faltas, os espaços em branco, o "inconsciente" do sistema. O modelo - científico - de explicação termina sendo mesmo uma das garantias da morte do objeto explicado. 101

Este discurso, e suas muitas variações contra a sociedade ocidental e de questionamento à metodologia da ciência, é tanto mais curioso por ser manifestado por setores da própria comunidade científica. Naturalmente não cabe aqui entrarmos nesta questão complexa. Registre-se apenas que, quando alguém se propõe a escrever uma tese acadêmica, atividade que se enquadra na tradição da ciência moderna, fica implícito que deve estar de acordo com a ideia de objetividade científica, que parece que o autor procurou desqualificar chamando de "racionalidade positiva", e, se essa tese for de alguma das Ciências Humanas, que essa disciplina faça sentido em existir e não contribua para a "morte de seus objetos". ${ }^{102}$

\footnotetext{
${ }^{99}$ SODRÉ, Muniz. Samba: o dono do corpo. 2ª ed.. Rio de Janeiro: Mauad, 1998, p. 10.

100 Ibidem, p. 9. Para Sodré a palavra "significação" pode aventar o emprego da "semiologia", mas ele faz questão de deixar claro que não entende semiologia "como essa pesquisa maníaca de estruturas formais que tanto parece fascinar os amanuenses culturais dessa colônia e d'além mar". pp. 9-10.

101 Ibidem, p. 9.

102 Karl Popper define da seguinte maneira a questão da objetividade científica: "O que pode ser descrito como objetividade científica é baseado unicamente sobre uma tradição crítica que, a despeito da resistência, frequentemente torna possível criticar um dogma dominante. A fim de colocá-lo sob outro prisma, a objetividade da ciência não é uma matéria dos cientistas individuais, porém, mais propriamente, o resultado social de sua crítica recíproca, da divisão hostil-amistosa de trabalho entre cientistas, ou sua cooperação e também sua competição. Por esta razão depende, em parte, de um número de circunstâncias sociais e políticas que fazem possível a crítica." POPPER, Karl. Lógica das Ciências Sociais. 2a ed.. Rio de Janeiro: Tempo Brasileiro, 1999, p.23.
} 
Ao procurar localizar na cultura negra as fontes geradoras de significação do samba, o autor parte da premissa, apresentada de maneira um tanto axiomática, de que o samba é tática de resistência cultural, categoria que se tornou importante nos estudos da música popular no período que estamos analisando. "Quanto ao aspecto de resistência, não há lugar para dúvidas, basta saber 'ler' ou escutar a história da música negra", afirma Sodré. ${ }^{103}$ Essa é uma das linhas de pensamento no debate acerca da questão das origens do samba que remonta aos anos 1930, conforme dito anteriormente. Ao partir deste pressuposto de que o samba é resistência cultural negra e não produto de um encontro de culturas, o autor vai buscar exclusivamente na cultura negra as fontes geradoras de significação para o samba.

Em Samba: o dono do corpo, a ideia do samba como resistência negra está ancorada na concepção de que a síncope seria uma forma de manutenção da matriz rítmica africana nas músicas da diáspora negra, uma forma de resistência cultural. 0 escravo teria infiltrado sua concepção rítmica nas formas musicais brancas. Essa seria uma tática de falsa submissão: "o negro acatava o sistema tonal europeu, mas ao mesmo tempo o desestabilizava, ritmicamente, através da síncopa - uma solução de compromisso". ${ }^{104}$ Em uma passagem bastante citada em pesquisas acadêmicas Sodré afirma que a síncope ${ }^{105}$ incita o ouvinte a preencher o tempo vazio com a marcação corporal. "E o corpo exigido do samba é aquele mesmo que a escravatura procurava violentar e reprimir culturalmente na História brasileira: o corpo do negro".106 A passagem é interessante como licença poética, foi inúmeras vezes reproduzida, mas não tem nenhuma sustentação musicológica. Síncope é um conceito surgido na música ocidental, dentro da lógica de sua estruturação rítmica que, assim como o sistema tonal, são eventos recentes na história da humanidade - se consolidaram há não mais do que quatro séculos. A ideia de síncope é indissociável da ideia de compasso como organização de pulsações com acentuações recorrentes. Assim como o sistema tonal107, os conceitos de compasso e de síncope fazem parte da música da tradição européia, não

\footnotetext{
103 SODRÉ, Muniz. Samba: o dono do corpo. 2ª ed.. Rio de Janeiro: Mauad, 1998, p. 56.

104 Ibidem p. 25.

105 Prefiro a grafia síncope mas mantive síncopa na citação de Sodré. As duas formas existem em português. 106 Ibidem, p. 11.

107 No sistema tonal, a formação de escalas e acordes é determinada pela eleição de uma nota fundamental como centro, em torno do qual as demais ficam relacionadas hierarquicamente; as melodias e progressões harmônicas, em uma dada tonalidade, tendem a se orientar em direção a esse centro.
} 
têm validade universal e não expressam fenômenos da natureza; são construções culturais ocorridas num determinado lugar e momento histórico. A aplicação destes conceitos a outros sistemas musicais, como o africano, que têm outra lógica de organização das divisões do tempo, constitui uma impropriedade. É uma contradição com suas premissas o fato de que Sodré se apoie num conceito da música ocidental para sustentar sua tese. Por outro lado, a admissão da aceitação do sistema tonal por parte dos negros deveria acender uma luz de alerta, provocar uma reflexão crítica, pois o fato de que o samba "aceite o sistema tonal" não é um pequeno detalhe irrelevante e isso sugere no mínimo uma reflexão no caminho do encontro de culturas. Aceitar o sistema tonal implica que essa música também faz parte daquilo que se entende por música ocidental, ou seja, todas as músicas que, em maior ou menos grau, derivam da tradição musical europeia.

A discussão sobre a síncope no samba e, por extensão, na música brasileira e das Américas em geral, já tinha muitos antecedentes que remontam a intervenções de musicólogos, folcloristas e cultuadores do samba. Aliás, desde a discussão proposta por Mário de Andrade no Ensaio sobre a música brasileira ${ }^{108}$ essa questão tem pautado (ou assombrado, dependendo do ponto de vista) os estudos da música popular no Brasil. Em Feitiço Decente, transformações no samba no Rio de Janeiro (1917-1933) ${ }^{109}$ Carlos Sandroni aponta essa questão da utilização geral e indiscriminada do conceito de síncope. Segundo Sandroni, tornou-se um lugar-comum "considerar-se as síncopes como índice de uma certa 'especificidade musical' brasileira", valendo isso para estudiosos de nossa música, para compositores acadêmicos e ainda para praticantes e apreciadores da música popular, "que, sem jamais ter aberto um livro de teoria musical, usam e abusam de expressões como 'samba sincopado'”. ${ }^{110} \mathrm{O}$ autor faz um arrazoado bastante esclarecedor sobre essa questão da síncope que não cabe ser reproduzido aqui, mas cujos argumentos eu compartilho.

Outra elaboração de Sodré que foi profícua para muitas pesquisas é a ideia dos "biombos culturais". Analisando o que chama de "economia semiótica" da casa da Tia Ciata, o autor faz uma leitura de sua disposição musical: bailes (polcas, lundus, etc.) na

\footnotetext{
108 ANDRADE, Mário de. Ensaio sobre a música brasileira. São Paulo: Livraria Martins, 1972, pp.29-39. 109 SANDRONI, Carlos. Feitiço decente: transformações no samba no Rio de Janeiro (1917-1933). Rio de Janeiro: Zahar, 2001.

110 Ibidem, p.20.
} 
sala de visitas; samba de partido-alto na parte dos fundos; e batucada no terreiro. Considera esta disposição "metáfora viva das posições de resistência adotadas pela comunidade negra". Os sambas "da elite negra da ginga e do sapateado" e a batucada dos negros mais velhos onde se fazia presente o elemento religioso, eram realizados nos fundos da casa, protegidos pelos biombos culturais da sala de visitas, onde se executavam "músicas e danças mais conhecidas, mais 'respeitáveis"”.111 José Miguel Wisnik considerou que essa elaboração de Sodré não apenas dava "forma a um movimento de afirmação de contingentes negros no espaço social do Rio de Janeiro", mas também captava e configurava “em suas próprias 'disposições e táticas de funcionamento' o modo de articulação mais geral das mensagens culturais da sociedade" brasileira. ${ }^{112}$ Nessa linha de pensamento, o autor desdobra a ideia dos "biombos" numa perspectiva mais ampla da sociedade, incluindo aí os saraus e as salas de concerto, as gravações e o rádio, numa elaboração que reforçou a imagem dos "biombos culturais" entre os pesquisadores da música popular. ${ }^{113}$

O livro de Muniz Sodré foi fértil em apresentar elementos que foram referência para muitas pesquisas, mas também apresentava alguns problemas que iriam se manifestar em muitos trabalhos: uma narrativa centrada numa visão dualista da questão étnica no Brasil, a utilização do jargão marxista como um senso-comum acadêmico e uma visão ideologizada da relação da música com o mercado. Em Samba, o dono do corpo encontramos as expressões pequena-burguesia, forças produtivas, modo de produção, valor de uso e valor de troca, conceitos que fazem parte do pensamento econômico marxista, utilizados com a naturalidade com que se lida com algo universalmente aceito. 0 texto de Sodré também apresenta a ideia da expropriação branca do samba negro, concepção que também está presente nos textos de Tinhorão. Para o autor, a classe média branca, tornando-se produtora sistemática de sambas e fazendo passar através deles novas significações culturais, estaria expropriando um instrumento expressivo dos negros pobres. Temos aqui a visão de um Brasil dividido

\footnotetext{
111 SODRÉ, Muniz. Samba: o dono do corpo. 2ª ed.. Rio de Janeiro: Mauad, 1998, p. 15.

112 WISNIK, José Miguel. Getúlio da paixão cearense (Villa-Lobos e o Estado Novo). In: Música: o nacional e o popular na cultura brasileira. São Paulo: Brasiliense, 1982, pp. 158-159.

113 A casa da Tia Ciata também é detalhada por Roberto Moura, que reproduz inclusive uma planta da casa conforme depoimentos de parentes que lá conviveram, para melhor compreensão da distribuição dos cômodos. Moura não se utiliza da expressão "biombos culturais" e define a casa de Ciata como a capital da Pequena África no Rio de Janeiro. MOURA, Roberto. Tia Ciata e a pequena África no Rio de Janeiro. Rio de Janeiro: FUNARTE, 1983.
} 
entre negros e brancos, uma visão racialista que infelizmente vem recrudescendo no Brasil nos últimos anos em função de interesses de agendas políticas. É verdade que Sodré ameniza sua afirmação, dizendo que essa "expropriação" (já entre aspas) "não deve ser vista, paranoicamente, como um roubo deliberado" dos valores de uma classe por outra, mas como decorrência do processo produtivo. ${ }^{114}$ Nesse sentido, sua elaboração sociológica é mais refinada do que a de Tinhorão, mas a visão dual persiste mesmo com esta ressalva.

Em livro dedicado à sociologia do mundo rural no país, José de Souza Martins incluiu um artigo sobre a música intitulado Música Sertaneja: a dissimulação na linguagem dos humilhados, primeiro texto acadêmico sobre o gênero sertanejo, que se tornou referência e inspirou pesquisas posteriores. A partir de um olhar sociológico, para Martins, "o discernimento das condições sociais de produção e emprego da música é o ponto central para desvendar-se o seu sentido". O autor faz uma distinção entre uma sociologia da música que teria por objeto "a música em si mesma" e "uma sociologia das relações sociais que tem a música como instrumento de mediação ou como resultado", opção na qual enquadra o seu ensaio. Segundo Martins, neste caso se trataria da música em sentido mais amplo, "abrangendo a letra que nela se suporta, o universo que verbaliza cantando e o universo que a utiliza como ponto de apoio em determinadas relações sociais". ${ }^{115}$ Segundo o autor, a primeira orientação seria aquela utilizada para a chamada grande música e dá como exemplo as obras de Adorno. No caso do seu ensaio, ele tem por objeto modalidades de música que teriam, seja nos ritos ou na letra, uma importância sociológica que não poderia ser apreendida na dimensão estritamente musical. Fica claro nesta sucinta definição do objeto que ele estava se referindo à canção popular, conceito naquele momento ainda não plenamente elaborado do ponto de vista das relações texto literário e texto musical. Entretanto, a distinção apresentada entre abordagens sociológicas em torno da música pode ter um alcance mais amplo, ou seja, ambas possibilidades poderiam ser aplicadas para distintos repertórios e gêneros musicais.

114 SODRÉ, Muniz. Samba: o dono do corpo. 2ª ed.. Rio de Janeiro: Mauad, 1998, p. 50.

115 MARTINS, José de Souza. Capitalismo e tradicionalismo: estudo sobre as contradições da sociedade agrária no Brasil. São Paulo: Pioneira, 1975, p. 103. 
Martins faz uma distinção entre música caipira e música sertaneja. Constata a existência de elementos comuns entre essas duas denominações, como a proliferação da música sertaneja na mesma região geográfica da cultura caipira e a transplantação de certos elementos formais da musicalidade caipira para a sertaneja. Mas enfatiza a existência de "diferenças significativas" que incidiram menos sobre os elementos de estruturação da música e mais sobre os componentes nos quais se insere a atividade musical. Observemos que o texto, escrito entre 1974 e 1975, refere-se ao que então se chamava de música sertaneja, duplas como Tonico e Tinoco, Leo Canhoto e Robertinho, Raul Torres e Florêncio, Alvarenga e Ranchinho, bem distantes em sua estética e poética daquilo que hoje se conhece como música sertaneja. A música caipira estaria sempre ligada a sociabilidades do mundo rural, como acompanhamento de rituais religiosos, de trabalho ou de lazer. Já a música sertaneja possuiria um fundamento de classe, e o autor procura ao longo do texto verificar de que modo ela exprimiria as condições concretas de existência das classes subalternas, com suas tensões e contradições, sua oposição histórica a outras classes e sua alienação. José de Souza Martins afirma rejeitar as concepções simplistas de que a música sertaneja seria ou reflexo direto das condições de existência das classes subalternas ou degeneração da cultura das classes dominantes. Mas seu ensaio está de toda maneira fortemente direcionado pela concepção da determinação da cultura pelas circunstâncias e dinâmica da luta de classes. Este trabalho teve eco imediato na dissertação de mestrado de Waldenyr Caldas, Acorde na aurora. ${ }^{116}$

Embora de menor repercussão que os trabalhos de Sant'Anna, Vasconcellos, Sodré e Martins, um livro de Sociologia da Comunicação tendo a música popular como objeto de estudo foi publicado em 1973: Música popular e comunicação ${ }^{117}$, de Carlos Alberto de Medina, que também privilegiava o estudo do discurso literário das canções. Ficavam assim delineadas nestes ensaios as disciplinas que iriam, num primeiro momento, tomar a música popular como objeto de estudo na pós-graduação: as áreas de Letras, Comunicação e Sociologia.

Nesta breve revisão destes textos fundamentais, podemos localizar alguns

\footnotetext{
116 CALDAS, Waldenyr. Acorde na aurora: música sertaneja e indústria cultural. Dissertação de mestrado em Sociologia. São Paulo: FFLCH-USP, 1976. Publicado com título homônimo, Editora Nacional, 1977.

117 MEDINA, Carlos Alberto de. Música popular e comunicação. Petrópolis, Vozes, 1973.
} 
conceitos e categorias que se tornaram recorrentes na literatura e que parecem pautar o surgimento do campo de estudos da música popular no Brasil: linha evolutiva, linguagem da fresta, rede de recados, biombos culturais, poesia cantada ou o universo que verbaliza cantando, resistência cultural e expropriação cultural. Some-se a isso algumas formulações em torno a questões centrais como a ideia do dia que virá, das concepções de autenticidade, raiz e tradição, além da eterna discussão da síncope. Estes conceitos e questões estão sendo abordados neste trabalho desde uma perspectiva crítica. Mas a formação de um corpo conceitual para se pensar a música popular no Brasil, ainda que a princípio vinculado a certas ideologias e concepções estéticas, demonstra originalidade na formação do campo em relação à agenda de estudos do mundo anglo-americano. É possível também identificar um diálogo, direto ou indireto, em concordância ou não, entre autores e obras, a exemplo das elaborações feitas por Wisnik em torno das proposições de linguagem da fresta e biombos culturais. Isto indica a existência, neste ensaísmo dos anos 1970 e 1980, especialmente nas publicações em livros, sejam seus autores intelectuais acadêmicos ou não, de um processo de formação de um campo de estudos e de um sistema no qual as elaborações se comunicam. Na verdade, este processo representa para a música popular, de uma maneira mais ampla, algo similar ao que tinha ocorrido com o samba carioca até por volta do início da década de 1960, em torno do qual vinha se formando um conjunto de autores e obras, conforme discutido no capítulo anterior.

Antes do próximo item, dedicado às primeiras pesquisas realizadas na pósgraduação brasileira sobre música popular urbana, é necessária uma breve menção à tese de doutorado em Antropologia de José Baptista Borges Pereira, Côr, mobilidade e profissão: o negro e o rádio de São Paulo, defendida na USP em 1966 e publicada em 1967 com o mesmo título. ${ }^{118}$ Este não é um trabalho dedicado à música popular: tratase de um estudo da interação social dos negros na sociedade brasileira a partir da análise da sua integração nas empresas radiofônicas na cidade de São Paulo e da sua participação sociocultural decorrente desta integração. Ao analisar os fatores sociais e culturais que contribuíram para que o rádio se tornasse um espaço na estrutura

118 PEREIRA, João Baptista Borges. Côr, profissão e mobilidade: o negro e o rádio de São Paulo. São Paulo: Pioneira Editora / Editora da USP, 1967. Publicação da tese de doutorado homônima, defendida na área de Antropologia, FFLCH-USP, em 1966. 
ocupacional brasileira para a integração do negro, Borges Pereira dedica todo um capítulo à música identificada com a cultura negra. Para os objetivos da sua pesquisa, o autor definiu como música negra aquela que "é considerada tanto pelos brancos como pelos próprios pretos, como manifestação cultural do grupo de cor", independente do que "haja nela de autêntico ou de espúrio em termos de origem africana", com a ressalva que esta conclusão nem sempre seria legítima do ponto de vista técnico. ${ }^{119}$ Nesse sentido, Borges Pereira não se interessou em traçar um perfil da formação étnico-histórica da música brasileira popular. Interessou-se, entretanto, pelo processo através do qual a "música negra", clandestina e mal vista no começo do século, é aceita pela sociedade urbana e passa a ser identificada como "a música popular brasileira", apresentando, desta forma, um tema que seria objeto de muitas pesquisas posteriores. Elencou também tópicos que colocam perguntas pertinentes e profícuas à pesquisa sobre música popular: o processo de seleção pelo rádio de um tipo de música dentre as diferentes manifestações populares que a cultura brasileira exibia no momento e os fatores responsáveis por tal seleção; o processo através do qual essa música ao ganhar status na cultura nacional, propiciou aos elementos humanos a ela associados a conquista de novas posições profissionais. $\mathrm{O}$ autor vai concluir que a revalorização dessa música e de todo o complexo cultural a ela ligado, decorrência de sua exploração comercial, trouxe consigo a valorização do elemento humano historicamente identificado a tal expressão de cultura, adequando-o às exigências do contexto de atividades remuneradas que então se configuravam pela primeira vez em nossa estrutura ocupacional. ${ }^{120}$

Talvez tenha sido esta a primeira pesquisa acadêmica a tomar a música popular urbana como elemento para estudos sociais mais amplos, num momento em que o pensamento sobre a música popular estava direcionado para as polêmicas e embates estético-políticos em curso. Foi um trabalho bastante citado nas pesquisas pioneiras, especialmente os depoimentos de velhos sambistas cariocas colhidos pelo autor. Em um deles já encontramos a descrição das festas na casa da Tia Ciata: "A festa era assim: baile na sala de visitas, samba de partido alto nos fundos da casa e batucada

\footnotetext{
119 PEREIRA, João Baptista Borges. Côr, profissão e mobilidade: o negro e o rádio de São Paulo. São Paulo: Pioneira Editora/Editora da USP, 1967, p. 24-25 e 194.

120 Ibidem, p. 234-235.
} 
no terreiro. A festa era de preto, mas branco também ia lá se divertir. No samba só entrava os bons no sapateado, só a 'elite'”.121 Enfim, já em 1966 Borges Pereira apontou muitos elementos para a pesquisa que iria se desenvolver a partir dos anos 1970.

\subsection{AS PRIMEIRAS PESQUISAS ACADÊMICAS}

Até 1981, foram realizadas cerca de vinte pesquisas na pós-graduação nos Estados de São Paulo e Rio de Janeiro que podemos considerar fundadoras de um campo de estudos acadêmicos. Estas pesquisas estavam concentradas nas áreas de Sociologia, em São Paulo, e Letras e Comunicação, no Rio de Janeiro. Nesse período temos também em São Paulo dois trabalhos na área de Letras, um em Filosofia e um em História. No Rio de Janeiro, foi realizado também um trabalho em Filosofia e outro em Antropologia, área na qual se produziram também estudos das sociabilidades em torno do samba. Ou seja, o estudo da música popular já se configurava como multidisciplinar, abrangendo as Ciências Sociais e Humanidades de uma maneira ampla. Pode-se dizer que, em São Paulo, as pesquisas estiveram em sua maioria motivadas por acontecimentos recentes: a presença e o impacto da indústria e dos meios de comunicação na produção e consumo musical, e o advento da bossa nova, da MPB e da tropicália. No Rio de Janeiro, foram predominantes os temas relacionados ao samba carioca: origens, questões étnicas, ascensão social do sambista, padrão de música nacional e malandragem. De uma maneira geral, três questões estiveram mais presentes, como problemas para as pesquisas do período, explícitos ou de forma latente: a) as questões envolvendo a letra das canções, suas relações com a poesia literária e suas interações com o texto musical; b) as relações da produção musical com a indústria e o mercado; c) as relações entre a música popular e a questão étnica no Brasil.

Especialmente no Rio de Janeiro e na área de Letras, mas também em São Paulo e em outras áreas, desenvolveu-se uma linha de pesquisa baseada na análise do discurso do texto literário das canções, estudos que focalizavam apenas o plano discursivo das letras das canções. Estas pesquisas tiveram um grande impulso nos

121 PEREIRA, João Baptista Borges. Côr, profissão e mobilidade: o negro e o rádio de São Paulo. São Paulo: Pioneira Editora/Editora da USP, 1967, p.225. 
eventos dos anos 1960 que consolidaram o status da canção popular como produto artístico com espaço privilegiado na cultura nacional. Foram constituintes do campo de estudos propriamente acadêmico, ao lado das pesquisas antropológicas acerca das sociabilidades em torno do samba. Conforme discutido anteriormente, as letras das canções passaram a ser valorizadas como texto literário. Foi um lugar-comum na época considerar-se a música popular como a poesia cantada. Por esta via também a música popular encontrava legitimação enquanto objeto válido no campo científico. Se o texto musical era ainda visto como pobre e indigno de estudos sérios na área de Música, na área de Letras o texto literário das canções era admitido como uma peça de análise perfeitamente justificável e utilizado como material de estudo nos cursos secundários e de graduação. Contribuiu neste processo o enriquecimento semântico das letras das canções e a aproximação com a poesia literária e a cultura erudita a partir dos anos 1960. Mas também contribuiu o fato de que intelectuais ligados ao estudo e à produção literária tenham se ocupado da música popular, seja como ensaístas ou orientadores de trabalhos acadêmicos, entre os quais Affonso Romano de Sant'Anna, Afrânio Coutinho, Antônio Risério, Augusto de Campos, Antonio Candido, Heloisa Buarque de Hollanda, Haroldo de Campos, Luiz Costa Lima, Silviano Santiago e Walnice Nogueira Galvão.

De uma maneira geral os pesquisadores eram conscientes de que algo na formação do sentido na canção estava se perdendo nesta linha de abordagem, mas, naquele estágio do desenvolvimento das pesquisas, não encontravam outro caminho. Praticamente todas as pesquisas continham algum comentário explicativo ou justificativo para esta opção de se trabalhar apenas com o texto literário, mesmo que isso se limitasse a apenas um parágrafo. Ou seja, a questão da interação texto e melodia nas canções era um problema que estava no ar. Alguns trabalhos inclusive apresentam elaborações a esse respeito, como veremos mais adiante. Esta questão era de fato importante na medida em que estes trabalhos não se propunham apenas a análises literárias do texto linguístico das canções, mas também a derivar elaborações históricas e sociológicas a partir da análise do discurso. As pesquisas produzidas nesta linha formam o conjunto mais homogêneo de trabalhos do período, tendo marcado fortemente os estudos sobre música popular. 
A questão das relações entre texto literário e melodia era um desafio teórico metodológico para o campo em formação. Além das elaborações mais superficiais que podemos encontrar em diversos trabalhos do período, alguns pesquisadores enfrentaram de maneira mais direta esta questão, que estava no ar, como um "espírito do tempo". Um exemplo é Fonemas e vocábulos musicais no comportamento psicosocial $^{122}$, um dos primeiros trabalhos realizados sobre música popular no Brasil, o segundo realizado em São Paulo. Nesse trabalho, Sebastião Jorge Chammé desenvolve um raciocínio a partir da percepção das relações da música, em especial da canção popular, com a linguagem falada. 0 autor procura aproximar informações musicais com a linguística e a semiótica de Saussure, mas não logra apresentar um sistema articulado e convincente. Podemos considerar o trabalho como um exemplo do momento de formatação do objeto e busca de metodologias para analisá-lo. Embora o objeto seja a música popular, isso não é assumido claramente. Inclui umas poucas partituras, mas a maioria das citações musicais são letras de canções. Enfim, trata-se de um caso à parte, que não teve continuidade, não apresenta nenhuma formulação a ser recuperada, mas é indicativo de que se fazia necessária uma elaboração sobre essa relação texto-melodia.

Uma outra investida nessa direção foi a dissertação de mestrado de Marilena Esberard de Lauro Montanari, 0 poema-canto gerado na dialética: música $x$ texto literário ${ }^{123}$, trabalho que teve a orientação de Haroldo de Campos. A autora define o campo de sua pesquisa como sendo a Música Popular Brasileira Contemporânea (com maiúsculas) e, dentro dela, a faixa dos inventores. ${ }^{124}$ Afirma procurar uma nova forma de atitude estética, o poema-canto, a letra vinculada à melodia. Entende que não se deve abordar de maneira isolada da poesia contida nas canções então contemporâneas e procura realçar a indissolubilidade dos processos do fazer poético e o do fazer musical na canção. A autora vê o canto-poema como uma nova expressão estética brasileira que oscila entre canto e poesia:

Toda e qualquer canção popular, desde que cantada, é um signo composto de letra + melodia. A novidade que buscamos é a canção que faça da união letramelodia um laço indissolúvel e que procure transcender à pura

\footnotetext{
122 CHAMMÉ, Sebastião Jorge. Fonemas e vocábulos musicais no comportamento psico-social. Dissertação de mestrado em Sociologia. São Paulo: Escola de Sociologia e Política, 1973.

123 MONTANARI, Marilena Esberard de Lauro. O poema canto gerado na dialética: musica popular x texto literário. Dissertação de mestrado em Comunicação. PUC/SP, 1980.

124 Inventores aqui se refere à classificação dos escritores feita por Ezra Pound em ABC da Literatura. Ver nota 77.
} 
referencialidade da mensagem. 0 engendramento da letra com a melodia se traduz dialeticamente. A letra para a melodia e a melodia servindo à letra. Poema cantado. Música trançada poeticamente. ${ }^{125}$

Embora caminhando na direção da percepção da relação texto-melodia como um conjunto semiótico, a elaboração fica comprometida na medida em que parte do pressuposto de um status diferenciado para uma parcela da produção que ela identificou como a faixa dos inventores - bossa-MPB-tropicália -, e apenas para este segmento seriam válidas suas formulações. Além da proposição não ter validade universal, o trabalho não faz a prometida análise texto-melodia como unidade indissociável. Enfim, também não apresentou uma formulação consistente para a questão da interação texto-melodia.

Durante os anos 1980, as pesquisas semióticas de Luiz Tatit ofereceram um novo quadro teórico para se abordar as relações entre texto literário e melodia nas canções brasileiras. Suas elaborações constituem a mais original contribuição metodológica aos estudos sobre a canção popular desenvolvida no Brasil. A originalidade e relevância dos estudos de Tatit reside na construção de um modelo teórico para compreender a compatibilização entre texto melódico e texto literário na formação do sentido nas canções, que se apresenta como importante ferramenta para análise do objeto. Na construção de seu modelo para uma semiótica da canção brasileira, Tatit tem como referência a semiótica francesa da Escola de Paris, partindo de alguns princípios fundadores de Saussure e Hjelmslev e das revisões críticas do modelo de Greimas realizadas por Claude Zilberberg. Entretanto, este modelo teórico se tornaria uma das principais referências nos estudos da canção popular apenas a partir dos anos 1990, quando o autor publica $O$ Cancionsita, e outros textos, nos quais apresenta seu modelo de uma maneira acessível para não iniciados em semiótica, oferecendo um marco teórico para se pensar a questão da análise do discurso literário no contexto do conjunto semiótico a que se chama canção.

De um modo geral, o estilo dos trabalhos era ensaístico, num momento de construção de metodologias para o estudo de um objeto novo para o qual estas pesquisas estavam abrindo o caminho no campo científico, tanto mais que as pesquisas

125 MONTANARI, Marilena Esberard de Lauro. O poema canto gerado na dialética: musica popular x texto literário. Dissertação de mestrado em Comunicação. PUC/SP, 1980, p. 106. 
se desenvolviam sem contato com a musicologia, em sua maioria por pesquisadores sem treinamento técnico em música. Por vezes, essa ausência de um quadro teóricometodológico estabelecido era contornada com a proposta de se evitar a utilização de metodologias rígidas para não engessar o objeto, para “deixar falar o objeto".

Do ponto de vista do trabalho com as fontes, encontramos duas situações: para aquelas pesquisas que abordavam eventos recentes ou contemporâneos, como os primeiros trabalhos realizados em São Paulo, as fontes não eram um problema, os dados estavam em geral, disponíveis; já os trabalhos com uma perspectiva temporal mais ampla, como os realizados no Rio, as fontes eram as gravações, as letras das canções, o trabalho de memorialistas, a historiografia não acadêmica e depoimentos disponíveis dos personagens. ${ }^{126}$ Aqui já aparecem as dificuldades de acesso às fontes, a ausência de acervos, bem como as primeiras citações de fontes que se tornaram canônicas. Embora no período apenas um trabalho tenha sido realizado na área de História, podemos localizar neste momento o surgimento de uma historiografia acadêmica da música popular, uma vez que muitos destes trabalhos construíram narrativas históricas acerca da música popular no Brasil ou de eventos socioculturais a ela relacionados.

Inicialmente, seria importante reafirmar que a produção realizada nas áreas de Letras, Comunicação e Sociologia, durante os anos 1970 e início dos 1980, contribuiu, além da formatação de um objeto de estudos acadêmicos, para a construção de uma visão da história da música popular no Brasil, constituindo-se assim, num ponto de partida, um "marco zero" da historiografia acadêmica. Dois dos trabalhos mais emblemáticos realizados na área de Letras são $O$ malandro no samba: uma linguagem de fronteira ${ }^{127}$, de Cláudia Neiva Matos, e Desenho Mágico: poesia e política em Chico Buarque, de Adélia Bezerra de Menezes $^{128}$. Estas pesquisas, ambas publicadas num momento em que ainda não existia o atual boom editorial sobre música popular,

\footnotetext{
126 Sobre este aspecto ver: STROUD, Sean. The defense of tradition in Brazilian popular music: politics, culture and the creation of Música Popular Brasileira. Hampshire: Ashgate Publ., 2007.

127 MATOS, Cláudia Neiva de. $O$ malandro no samba: uma linguagem de fronteira. Dissertação de mestrado em Letras, PUC-Rio, 1981. Esta dissertação teve a orientação de Silviano Santiago e foi publicada em 1982 com o título de Acertei no Milhar: samba e malandragem no tempo de Getúlio. Rio de Janeiro: Paz e Terra.

128 MENESES, Adélia Bezerra de. Desenho Mágico: estudo quase acadêmico sobre Francisco Buarque de Hollanda, dito Chico. Tese de doutorado em Letras, FFLCH-USP, 1980. Esta tese teve a orientação de Antonio Candido e também foi publicada em 1982, com o título de Desenho mágico: poesia e política em Chico Buarque. São Paulo: Hucitec.
} 
contribuíram para apresentar um modelo de pesquisa para a área de Letras, também incorporado por outras áreas. Mais do que isso, apresentaram duas visões, em certo sentido complementares, sobre dois momentos importantes da música popular no Brasil: a visão da malandragem no samba como uma resistência popular à dominação e a valorização da MPB, e mais particularmente da produção de Chico Buarque, como resistência possível e necessária ao regime militar. As autoras, e os pesquisadores do período de um modo geral, eram conscientes que, através da metodologia de análise do discurso do texto literário das canções, estavam também discutindo a história da música popular e a própria história do Brasil. Este duplo aspecto destas pesquisas está explicitado com clareza e concisão por Silviano Santiago na apresentação de Acertei no milhar, na orelha do livro:

O estudioso das Letras possui hoje um arsenal de análise de discurso que o torna privilegiado no presente estágio dos estudos históricos. Este arsenal constituído e aperfeiçoado nos estudos das chamadas "belles lettres" - tem sido dirigido para outras formas discursivas, que não tiveram a nobreza artística da literatura na sociedade ocidental. Nomeá-las e estudá-las passou a ser a maneira como as Letras colaboram com as Ciências Sociais, seguindo de perto as diretrizes mais instigantes das modernas correntes da historiografia européia.

Também Adélia Bezerra de Menezes escreve na introdução de Desenho Mágico: "A proposta do estudo dessa obra, circunscrita a duas décadas de produção de Chico Buarque, é a de estabelecer um paralelo com a História recente do Brasil, dos anos marcados pela Ditadura Militar: mais especificamente, de 1964 a 1980".129

Outra vertente, nestas primeiras pesquisas, era a sociologia da comunicação, estudos voltados para as questões da produção, recepção e consumo da música popular, vertente esta que teria uma certa descontinuidade até ser retomada mais recentemente num momento em que os estudos sobre música popular já se encontravam consolidados no campo acadêmico. Nesta linha se situam as duas primeiras dissertações de mestrado realizadas em São Paulo que tiveram como tema central de estudo a música popular: Canção popular e indústria cultural ${ }^{130}$, de Othon

\footnotetext{
129 MENESES, Adélia Bezerra de. Desenho mágico: poesia e política em Chico Buarque. 2ª ed.. São Paulo. Ateliê Editorial, 2000, p.17.

130 JAMBEIRO, Othon. Canção popular e indústria cultural. Dissertação de mestrado em Sociologia, FFLCH-USP, 1971.
} 
Jambeiro e Acorde na Aurora: música sertaneja e indústria cultural ${ }^{131}$, de Waldenyr Caldas, ambas publicadas nos anos 1970.132 O livro de Waldenyr Caldas, sobre um gênero ainda hoje relativamente marginalizado nos estudos sobre a música popular, teve grande repercussão. Observe-se, entretanto, que este estudo, que faz uma distinção entre música caipira, ligada ao folclore rural, e música sertaneja, como produto da urbanização da música caipira em estreita ligação com o mercado, apresenta uma perspectiva muito crítica à música sertaneja, entendida como produto de uma indústria cultural.

Estes primeiros estudos da sociologia da comunicação, com o foco na produção e consumo da canção urbana, estavam sintonizados com um processo em curso, de transformações no mercado musical, nas tecnologias de produção e reprodução sonora e suas repercussões na música popular. ${ }^{133}$ Tinham, entretanto, uma visão bastante pessimista e crítica em relação ao mercado. Nos trabalhos de Jambeiro e Caldas, e na maior parte das pesquisas dos anos 1970 e 1980, é forte a influência das ideias de Adorno, especialmente o conceito de indústria cultural. ${ }^{134}$ Em Acorde na Aurora, o conceito de indústria cultural é utilizado no sentido forte, radical, explicitando a ideia do consumidor passivo, vítima indefesa dos interesses comerciais da indústria que lhe determinariam o gosto estético:

Hoje, entretanto, com a Indústria Cultural agindo no gosto estético das massas e determinando o que elas devem consumir, esse problema [de discutir as implicações que determinam o gosto estético] ganha maior complexidade na

131 CALDAS, Waldenyr. Acorde na aurora: música sertaneja e indústria cultural. Dissertação de mestrado em Sociologia, FFLCH-USP, 1976.

132 JAMBEIRO, Othon. Canção de massa: as condições da produção. São Paulo: Pioneira, 1975; CALDAS, Waldenyr. Acorde na Aurora: música sertaneja e indústria cultural. São Paulo: Editora Nacional, 1977.

133 Se todos estes estudos têm que ser analisados em relação ao momento de sua produção, isso se torna ainda mais relevante para as discussões acerca das questões do mercado e das novas tecnologias. Talvez a melhor forma de ressaltar isso para leitores que não viveram os anos 1970 seja através da passagem de Othon Jambeiro sobre a mixagem. Ao discorrer sobre as então modernas técnicas de gravação o autor afirma que elas podem levar a um aperfeiçoamento, quando usadas "honestamente", considerando a mixagem, em geral, um engodo. Aqui tem que se pensar que ele estava falando de um fenômeno muito novo e ainda "acontecendo". 0 autor menciona que em outros países já se gravava em até 24 canais, enquanto no Brasil o equipamento existente permitia apenas a divisão em seis pistas independentes. JAMBEIRO, Othon. Canção popular e indústria cultural. Dissertação de mestrado em Sociologia, FFLCH-USP, 1971, p. 46. Atualmente, qualquer pessoa que possua um computador pode gravar no seu quarto, rodando um programa bastante amigável, uma infinidade de canais, tendo como único limite o tamanho da memória e a capacidade de processamento do seu hardware.

134 Os textos de Adorno em debate eram principalmente aqueles que haviam sido traduzidos até então: os constantes de Os Pensadores, volume XLVIII, da Editora Abril, cuja 1a edição foi publicada em 1975; Indústria cultural: o Iluminismo como Mistificação das Massas, com Horkheimer, em Teoria da Cultura de Massas, 1969; e Indústria Cultura in: Comunicação e Indústria Cultural, organizado por Gabriel Cohn, 1971. Em 1986 o no 54 da coleção Grandes Cientistas Sociais (organizada por Gabriel Cohn), oferece outros textos em português, entre eles Sobre música popular. 
medida em que o consumidor, independentemente da classe social a qual pertence, já não possui autonomia suficiente para determinar seu gosto estético. Ao contrário, essa função individual ou de classe, desaparece com o advento da Indústria Cultural. Esta sim, é que determina o gosto estético do consumo. ${ }^{135}$

No caso específico do Brasil dos anos 1970, é necessário considerar que esta leitura do papel da chamada indústria cultural ficava facilitada num contexto de apoio de importantes veículos de comunicação de massa ao regime militar, como a TV Globo e o jornal Folha de S. Paulo. A repressão da ditadura não era apenas política, mas também cultural e comportamental. Acrescente-se a isso o controle da indústria fonográfica no Brasil por companhias multinacionais e a política dos Estados Unidos de apoio aos regimes autoritários no Brasil e na América Latina. A posição que estes trabalhos expressam acerca do mercado de bens culturais é representativa de uma postura de hostilidade à industria do entretenimento, que era compartilhada por todos os setores da sociedade permeáveis às ideias de esquerda e por grande parte de setores mais amplos insatisfeitos com a conjuntura política.

De fato, é grande a presença do marxismo na maioria dos trabalhos do período, refletindo o ambiente da universidade brasileira naquele momento. Uma hipótese que se poderia levantar é que o marxismo nestes estudos entrava pela via da Escola de Frankfurt. Mas parece que não. Talvez a tendência fosse inversa: a assimilação das elaborações adornianas, tais como o conceito de indústria cultural, eram uma decorrência da força do pensamento marxista. A grande profusão com que é utilizado o jargão marxista - luta de classes, proletariado, pequena-burguesia, burguesia, lumpemproletariado, valor de uso, valor de troca, mais valia, modo de produção, forças produtivas, alienação - indica mais que esses conceitos estavam presentes no ambiente da universidade brasileira, como um senso comum acadêmico. Estes conceitos eram utilizados com naturalidade, sem que a pessoa abraçasse necessariamente todo o ideário marxista, de maneira consciente, como referencial teórico claramente definido. Era um marxismo de fundo, um background marxista que nem sempre vinha para o primeiro plano. Estes e outros conceitos serão observados mais de perto no Capítulo 4.

135 CALDAS, Waldenyr. Acorde na aurora: música sertaneja e indústria cultural. Dissertação de mestrado em Sociologia, FFLCH-USP, 1976, p. 30. 
Os estudos literários e de sociologia da comunicação, constituíram a vertente principal das pesquisas pioneiras, e a análise do discurso do texto literário das canções, a metodologia privilegiada. Não há, no período, nenhuma outra linha de pesquisa tão nitidamente delineada como esta. Alguns casos são bastante específicos, a exemplo de Contato musical transatlântico: contribuição Bantu à música popular brasileira ${ }^{136}$, de Kazadi Wa Mukuna. O autor investiga as heranças africanas na música popular brasileira a partir de um instrumental teórico etnomusicológico, agregando as elaborações do antropólogo e musicólogo austríaco Gerhard Kubik acerca da música africana, com pesquisa de campo e levantamento histórico-cultural dos Bantu do Zaire na busca dos elementos musicais de prováveis origens tribais em nossa música urbana, analisando também seu processo de mutação e persistência. Esta era uma linha de pesquisa bastante profícua que não teve continuidade imediata em outras pesquisas. Embora algumas citações a este trabalho fossem feitas, só recentemente algumas pesquisas dialogaram com suas elaborações.

Ainda no final da década de 1970, Celso Favaretto defendeu sua tese de doutorado, Tropicália: alegoria, alegria. Estudo clássico sobre a tropicália, um dos textos do período a seguir as pistas deixadas pelo Balanço da Bossa, apresenta uma posição mais arejada das relações da música popular com o mercado, em comparação a outras pesquisas contemporâneas, ainda muito direcionadas pela crítica implacável da chamada indústria cultural. Favaretto vai procurar entender o tropicalismo a partir da sua gestação nos embates político-sociais dos anos 1960. Para o autor, o tropicalismo constituiu "uma forma sui generis de inserção histórica no processo de revisão cultural, que se desenvolvia desde o início dos anos 1960", momento de "engajamento de grande parte dos intelectuais e artistas brasileiros na causa" das transformações sociais. Segundo Favaretto, os grupos engajados não estavam interessados na pesquisa estética e no experimentalismo e sim no objetivo de "falar do país" com uma linguagem adequada à conscientização do público. Para o autor, estes grupos mantiveram "durante toda a década uma polêmica de grande alcance cultural, em torno da oposição entre arte alienada e arte participante", com "agressividade, quando não desprezo,

136 MUKUNA, Kazadi Wa. O contato musical transatlântico: contribuição Bantu na música popular brasileira. Tese de doutorado em sociologia, FFLCH-USP, 1977. 
contra as tendências experimentalistas, assim como uma recusa da importação de formas, ritmos e estilos". 137 Segundo Favaretto,

\begin{abstract}
O tropicalismo nasceu dessas discussões, que já se exauriam, inclusive por força da repressão. Propunha outro tipo de discussão, substancialmente distinta das anteriores como tática cultural, como proposta ideológica e relacionamento com o público. Era uma posição definidamente artística, musical. Rearticulando uma linha de tradição abandonada desde o início da década, retomando pesquisas do modernismo, principalmente a antropofagia oswaldiana, rompeu com o discurso explicitamente político, para concentrar-se numa atitude "primitiva" que, pondo de lado a "realidade nacional", visse o Brasil com olhos novos. Confundindo o nível em que se situavam as discussões culturais, o tropicalismo deu uma resposta desconcertante à questão das relações entre arte e política. ${ }^{138}$
\end{abstract}

No estudo de Celso Favaretto encontramos a proposição de que a elevação do status da canção popular como arte se deu com o tropicalismo, que teria elaborado "uma nova linguagem da canção" que exigia "que se reformulassem os critérios de sua apreciação, até então determinados pelo enfoque da crítica literária". 0 tropicalismo teria assim realizado "a autonomia da canção, estabelecendo-a como um objeto enfim reconhecível como verdadeiramente artístico".139 Dentro desta concepção, o autor também analisa as letras das canções, mas o faz a partir das imagens alegóricas e intertextuais que elas veiculam, dando um passo adiante em relação às análises das metáforas poéticas em torno da subjetividade do artista e suas conexões com o seu contexto que caracterizavam outros estudos. Tinha, portanto, a percepção refinada da mudança do lugar social da canção no Brasil, apresentando essa proposição e situando esse reposicionamento na hierarquia de bens culturais a partir do tropicalismo. Autores posteriormente iriam rediscutir essa questão, apresentando novas contribuições para se compreender essa elevação do status social e cultural da canção. O trabalho de Celso Favaretto é ilustrativo do estágio em que se encontrava a pesquisa acadêmica sobre música popular no final dos anos 1970. 0 texto tem em certas passagens um tom um tanto apologético, que indica que o autor era também, naquele momento, um fã-acadêmico.

\footnotetext{
137 FAVARETTO, Celso Fernando. Tropicália: alegoria, alegria. Tese de doutorado em Filosofia. São Paulo: FFLCHUSP, 1978, p.10-12.

138 Ibidem, p.12.

139 Ibidem, p.15-16.
} 
Tomado de conjunto, o ensaísmo sobre música popular dos anos 1970 e 1980 seja nas pesquisas da pós-graduação ou em publicações voltadas para um público mais amplo - abriu caminho no campo acadêmico para um objeto até então desprezado, desconhecido e considerado indigno de estudos sérios. Estes trabalhos formataram um objeto de estudo e iniciaram a construção de um instrumental teórico para abordá-lo, em grande parte apoiados na teoria literária, na sociologia e nas semióticas em processo de elaboração. Embora possam se destacar trabalhos no período que se tornaram referência por suas elaborações e por apontarem caminhos para a pesquisa, no conjuntos esta produção pode ser considerada como um momento formativo de um campo de estudos.

Quanto aos referenciais teóricos, o principal corte em que os trabalhos podem ser divididos é entre aqueles que ecoavam posições adornianas, especialmente o conceito de indústria cultural e a visão da música popular como mercadoria estandardizada, e aqueles que buscavam outros referenciais, ainda que esta polêmica não tenha sido travada abertamente. Os outros referenciais em questão eram principalmente Umberto Eco (Apocalípticos e Integrados e Obra Aberta) ${ }^{140}$, Edgard Morin (Não se conhece a canção e Cultura de massas no Século XX) ${ }^{141}$, Walter Benjamin ( A Obra de arte na época de sua reprodutibilidade técnica $)^{142}$ e os textos constantes no livro Teoria da Cultura de Massa ${ }^{143}$, organizado por Luiz Costa Lima, que incluía autores como Abraham Moles, Marshall McLuhan, Julia Kristeva, Roland Barthes e Erwin Panofsky.

\subsection{TINHORÃO, WISNIK E CONTIER: LINHAS MESTRAS PARA A HISTORIOGRAFIA}

Para a historiografia acadêmica da música popular, e da música brasileira de um modo geral, que se constituiu a partir da década de 1980, a obra de três autores merece destaque. Os trabalhos de José Ramos Tinhorão, José Miguel Wisnik e Arnaldo

\footnotetext{
140 ECO, Umberto. Apocalípticos e Integrados. São Paulo: Perspectiva, 1970; Obra Aberta. Perspectiva, 1968.

141 MORIN, Edgar. MORIN, Edgar. Não se conhece a canção. In: Linguagem da Cultura de Massas: televisão e canção. Coleção Novas Perspectivas em Comunicação no 6, Vozes, 1973; Cultura de Massas no Século XX. Rio de Janeiro: Editora Forense Universitária, 1967.

142 BENJAMIN, Walter. A obra de arte na época de suas técnicas de reprodução. In: LIMA, Luiz Costa. Teoria da Cultura de Massa. Rio de Janeiro: Editora Saga, 1969.

143 LIMA, Luiz Costa. Teoria da Cultura de Massa. Rio de Janeiro: Editora Saga, 1969.
} 
Daraya Contier, pela originalidade de suas pesquisas, pelas distintas e conflitantes abordagens metodológicas empregadas e por suas diferentes visões da história da música no Brasil, transformaram-se em referências fundamentais para esta historiografia.

O trabalho de José Ramos Tinhorão já foi abordado no capítulo anterior, dedicado à tradição historiográfica não acadêmica, caracterizada por concepções nacionalistas e de defesa da autenticidade e das raízes populares da música brasileira, entendida com um certa linhagem articulada em torno da música popular do Rio de Janeiro. Tinhorão é o principal herdeiro desta tradição, mas vai além, apresenta um amplo leque de questões como programa de estudo, com pesquisa de fontes e seu trabalho é norteado por uma metodologia definida, o que o aproxima da tradição da pesquisa científica. Tornou-se uma referência fundamental para os pesquisadores acadêmicos, mais pelos dados, fontes e temas para reflexão que apresenta do que propriamente pela sua narrativa da história, reducionista, pautada por uma visão determinista, linearidade na sucessão de gêneros musicais e submissão do sentido cultural e político da música às ligações de classe de seus agentes criadores. Seus livros podem ser considerados emblemáticos de um paradigma historiográfico que tem repercussão na historiografia da música, o materialismo histórico, no caso de Tinhorão, numa leitura rígida e um tanto estreita. Existem posições mais arejadas a partir da perspectiva marxista, o que será discutido no capítulo 4, mas, para uma visão que privilegia a luta de classes como motor da história, para a qual toda a cultura é uma cultura de classes e que acredita na determinação da superestrutura pela base, a obra de Tinhorão apresenta-se como uma linha mestra de pensamento da história da música no Brasil.

A seguir, serão discutidas outra duas vertentes importantes na historiografia, os trabalhos de José Miguel Wisnik e Arnaldo Contier, autores diretamente vinculados à Universidade e que trabalharam originalmente com o campo de produção erudito. Segundo Marcos Napolitano, Wisnik e Contier apresentaram inovações no pensamento sobre a história da música brasileira para além da dicotomia erudito/popular:

Os trabalhos de ambos, sobre a vanguarda musical dos anos 1920/1930, apontavam para uma conexão inovadora entre estética e ideologia e, ressalvadas as diferenças de objeto e abordagens, o que se pode dizer é que, do ponto de vista metodológico, ambos exploravam as tensões e contradições entre projeto autoral, fatura estética e circulação sócio-cultural. 0 problema da identidade nacional se colocava de maneira dialética, sem os vícios 
nacionalistas da historiografia tradicional (Renato Almeida, Vasco Mariz, Oneyda Alvarenga). ${ }^{144}$

\subsubsection{Wisnik: uma leitura da formação da música brasileira}

José Miguel Wisnik teve formação de pianista erudito, cursou a faculdade de Letras e fez mestrado e doutorado em Teoria Literária. Seguiu paralelamente a atividade de ensaísta e cancionista e também, com o tempo, de intérprete de suas próprias canções. Originário do campo de produção erudita, tanto na música como na atividade acadêmica, aproximou-se da música popular na sua atividade de ensaísta e também de músico, sem perder contato ou romper com sua formação original. Constituiu-se assim, em suas próprias palavras, numa espécie de "Pestana às avessas". ${ }^{145}$ Pela sua própria trajetória, Wisnik esteve numa posição privilegiada para a reflexão que viria a desenvolver em seus ensaios sobre a dicotomia entre o erudito e o popular na música brasileira.

Em sua dissertação de mestrado, publicada no livro $O$ Coro dos Contrários: a música em torno da Semana de 22, ${ }^{146}$ Wisnik inicia o estudo das relações da música com a literatura no Brasil tendo por objeto privilegiado um momento específico e emblemático, a Semana de Arte Moderna de 1922, em estudo que se tornou clássico sobre o tema. Aqui o foco do autor ainda estava no estudo do campo de produção erudito. Já na sua tese de doutorado, Dança Dramática (poesia/música brasileira), ${ }^{147}$ Wisnik vai fazer um cruzamento de sua pesquisa sobre o Modernismo, que então se desdobrava no estudo das relações entre o pensamento musical e a poética de Mário de Andrade, com a atenção para a música popular que dedicava na sua atividade de crítico musical no jornal Última Hora. 0 estudo parte da intuição da existência de correntes subterrâneas que conectavam estes lugares aparentemente distantes, em suas palavras, "um túnel que passava necessariamente por zonas acidentadas e obscuras, e por

\footnotetext{
144 NAPOLITANO, Marcos. A Síncope das idéias: a questão da tradição na música popular brasileira. São Paulo: Editora Fundação Perseu Abramo, 2007, p.

1450 Pestana aqui mencionado é o personagem do conto clássico de Machado de Assis, Um Homem Célebre. Wisnik comenta suas atividades de professor, ensaísta e músico em entrevista a Luís Tatit, Arthur Nestrovsky e João Camillo Penna, publicada em Sem receita: ensaios e canções. São Paulo: Publifolha, 2004, p. 435-533.

146 WISNIK, José Miguel. A música em torno da Semana de Arte Moderna. Dissertação de mestrado em Letras, FFLCHUSP, 1974. Publicada como $O$ coro dos contrários: a música em torno da semana de 22. São Paulo: Duas Cidades, 1977. 147 WISNIK. José Miguel. Dança dramática (poesia / música brasileira). Tese de doutorado em Letras. FFLCH-USP, 1979.
} 
dimensões da vida cultural nem sempre explicitadas, embora subjacentes a grande parte das discussões envolvendo arte e sociedade".148 A proposta do autor é a “desobstrução" desse túnel, abrindo passagem entre estes diferentes domínios. 0 trabalho inaugura, desta forma, um olhar para a história da música no Brasil, para além da tradicional dicotomia entre o erudito e o popular.

Alguns anos antes, Affonso Romano de Sant'Anna já havia discutido as conexões entre poesia literária e música popular, aproximando assim os campos de produção erudito e popular, no que diz respeito ao texto literário. Mas o trabalho de Wisnik buscava um olhar para as conexões entre música e literatura de uma maneira mais ampla, na medida em que Mário de Andrade é um personagem central na história erudita brasileira e que o repertório musical popular que Wisnik abordou em sua tese, ainda que muito centrado na linhagem da MPB, comportou também outras vertentes. Entretanto, o autor estava em sua tese apenas iniciando seu projeto de "desobstrução do túnel”, para usar a sua própria metáfora, que poderia conectar esses distintos campos de produção. Nesse texto, o autor ainda não tinha atingido a articulação entre esses dois domínios que iria alcançar em estudos posteriores, como se pode depreender da própria apresentação do trabalho em dois capítulos bastante distintos. $O$ último texto da tese $O$ minuto e o milênio, ou, por favor professor, uma década de cada vez, traz uma concepção sobre a música brasileira que foi inovadora para o momento da pesquisa acadêmica ao propor em novos termos a questão do erudito e do popular na música brasileira, rompendo com a costumeira hierarquização. 0 autor afirma que a música erudita no Brasil "nunca chegou a formar um sistema onde autores, obras e público entrassem numa relação de certa correspondência e reciprocidade", ao passo em que vê na tradição da música popular no país inserção social, vitalidade, riqueza artesanal e "habilidade em captar as transformações da vida urbano-industrial" (expressão em voga na época). ${ }^{149}$ Comentando acontecimentos contemporâneos - a música na década de 1970 - Wisnik tem um olhar simpático para a produção de

\footnotetext{
148 WISNIK. José Miguel. Dança dramática (poesia / música brasileira). Tese de doutorado em Letras. FFLCH-USP, 1979 , p. II.

149 Ibdem, pp. 202-203. 0 artigo $O$ minuto e o milênio, ou, por favor professor, uma década de cada vez, foi escrito originalmente para o volume Música (em colaboração com Ana Maria Bahiana e Margarida Autran) da coleção Anos 70, dirigida por Adauto Novaes e publicada pela editora Europa em 1979. Está reproduzido no livro Sem receita: ensaios e canções (2004) com um breve balanço do autor que o situa no momento de sua redação.
} 
Roberto Carlos, o que destoava da crítica de então. ${ }^{150}$ Wisnik considerava a censura e a indústria cultural como temas centrais da década de 1970, escrevendo no curso dos acontecimentos. Dialoga com as elaborações de Theodor Adorno, identifica sua má vontade para com a música popular e indica que essas elaborações não poderiam ser transpostas para se pensar a música no Brasil, devido às suas especificidades, ainda que sem refutar de maneira mais incisiva o discurso adorniano.

Dança Dramática é um texto no estilo literário ensaístico que seria desenvolvido pelo autor, no sentido de que reúne e articula inúmeras erudições, desde as de aspecto literário, passando por conceitos antropológicos, psicanalíticos, sociológicos, musicológicos e análise de filmes. Mas o fio condutor de seu pensamento, que já se encontra esboçado nesse texto, parece ser uma adaptação para a música popular da metodologia desenvolvida por Antonio Candido no estudo da literatura brasileira. São indicações neste sentido a aplicação do conceito de formação de sistema, a utilização da ideia da existência de uma "dialética entre ordem e desordem" na cultura nacional e a utilização da sociologia e das ciências humanas numa análise integrada do objeto artístico nos seus aspectos internos e externos, que remetem ao método candidiano de análise literária. Vale lembrar que Antonio Candido foi orientador dos trabalhos de mestrado e doutorado de Wisnik. Ao comentar sua metodologia no livro Sem Receita, Wisnik reconhece a influência do mestre Antonio Candido em sua formação, acrescenta também seus professores no curso de Letras, David Arrigucci Jr. e Alfredo Bosi, e menciona formulações de Roberto Schwarz como referências relevantes.

Este olhar para a formação da música brasileira para além da dicotomia erudito/popular está elaborado de maneira mais articulada no ensaio Getúlio da Paixão Cearense (Villa-Lobos e o Estado Novo) ${ }^{151}$, leitura crítica do nacionalismo musical nos anos 1930 e 1940, centrada nas figuras de Mário de Andrade e de Villa-Lobos, sua produção e suas relações com o contexto sócio-político-cultural da época. Em sua

\footnotetext{
150 Segundo Wisnik a crítica não estava preparada para Roberto Carlos e se esquecia de pensar o óbvio: "que tipo de força o sustenta no ar por tanto tempo? Por que ele?" (1979, p.211). Curiosamente, uma variação dessa pergunta me foi formulada recentemente numa aula de História da Música Brasileira na UFU, cerca de 30 anos depois... A pergunta de Wisnik era óbvia, mas vale aqui lembrar Nelson Rodrigues e o "óbvio ululante", que clamando por reconhecimento, é ignorado olimpicamente.

151 WISNIK, José Miguel. Getúlio da paixão cearense (Villa-Lobos e o Estado Novo). In: SQUEFF; WISNIK. Música: o nacional e o popular na cultura brasileira. São Paulo: Brasiliense, 1982, p.129-191. O livro contém também o ensaio de Enio Squeff, Reflexões sobre um mesmo tema.
} 
análise do projeto do nacionalismo musical andradeano, Wisnik localiza a resistência à música popular urbana, vista como vulgar, desqualificada e comercial. Aponta como o uso de temas e motivações do folclore rural como fonte para a criação de uma linguagem musical artística nacional colocava esse projeto a salvo do efeito desestabilizador da música popular urbana, mais permeável às modernas linguagens musicais ${ }^{152}$. Vai mostrar assim, no curso de sua análise, como fica constituída o que ele chama de cadeia típica da discussão brasileira: "a conjunção entre o nacional e o popular na arte visa à criação de um espaço estratégico onde o projeto de autonomia nacional contém uma posição defensiva contra o avanço da modernidade capitalista, representada pelos sinais de ruptura lançados pela vanguarda estética e pelo mercado cultural". Segundo o autor, essa concepção na qual "nacional-popular tende a brigar com vanguarda-mercado", já era incisiva, nos anos 1930 e 1940 e estará no centro das tensões na área musical nos anos 1960.153 Encontra-se nesse ensaio também sua já mencionada e muitas vezes citada reelaboração da ideia dos biombos culturais proposta por Muniz Sodré. Wisnik acrescenta o sarau e a sala de concerto à proposição de Sodré, apresentando uma hierarquia social dos espaços musicais: terreiro de candomblé quintal de samba - salão de baile - sarau - sala de concerto. Inclui também uma ramificação mercadológica - rádio - gramofone - quintal de samba, que para o autor "deu inesperada margem de penetração alternativa à música popular, correndo por fora do sistema de difusão da arte" ${ }^{154} 0$ autor articula uma análise social desta cadeia na qual os biombos culturais seriam espaços a serem ocupados numa estratégia dos grupos dominados de reação à exclusão e afirmação de sua identidade.

Em Getúlio da Paixão Cearense, Wisnik ofereceu elaborações hoje plenamente assimiladas nas linhas atualizadas de leitura da história da música no Brasil, mas que foram inovadoras para o momento. Ao longo do texto, o autor apresenta uma leitura das questões do nacional e o do popular na música brasileira que apontou caminhos para a superação das narrativas tradicionais para a história da música no Brasil. Do ponto de vista de uma reflexão sobre o processo de construção do pensamento sobre a música no Brasil, é interessante observar, como, apesar de apresentar novos olhares,

\footnotetext{
152 Esta questão já havia sido apontada por Gilberto Mendes em ensaio de 1975, citado por Wisnik: MENDES, Gilberto. A música. In: ÁVILA, Affonso (org.). O modernismo. São Paulo, Perspectiva, 1975. p. 130.

153 WISNIK, José Miguel. Opus cit., p. 134.

154 Ibidem, p. 159.
} 
este texto ainda reverberava algumas concepções então em voga, como a suposta polarização entre sambas de exaltação à malandragem, que seriam parte de uma rica tradição na música popular carioca, e sambas que faziam a apologia da moral do trabalho.

José Miguel Wisnik foi refinando suas análises em ensaios posteriores ${ }^{155}$ ao longo do tempo e apresentou em Machado Maxixe: o caso Pestana ${ }^{156}$ uma ampla interpretação dos cruzamentos entre o erudito e o popular na formação da música brasileira. Wisnik considera que foi Machado de Assis "quem primeiro percebeu a dimensão abarcante que assumiria a música popular no Brasil, como instância a figurar e a exprimir, como nenhuma, a vida brasileira como um todo"157. Em torno da análise do conto clássico de Machado de Assis, Um homem célebre, ${ }^{158}$ Wisnik articula uma leitura de outros textos machadianos para, através da fina percepção do escritor, alinhavar sua interpretação das tensões entre o erudito e o popular na música brasileira, na qual tem destaque a originalidade da cultura mestiça no Brasil. Segundo Wisnik, Machado de Assis já se deparava, por volta do início do último quartel do século XIX, "com a identificação de uma fratura, operante no meio cultural brasileiro, entre o repertório de música erudita, que está longe de fazer parte de um sistema integrado de autores, obras, público e intérpretes, e a emergência de um fenômeno novo, a música popular urbana". ${ }^{159}$ A polca, entendida como a dança europeia em processo de transformação para "aquela outra coisa que se chamará maxixe”, já teria então se incorporado a um sistema deste tipo, despontando para a repercussão das massas, a identificação com a demanda do público e se realimentando de sua própria vendabilidade e familiaridade. ${ }^{160}$

Ao longo do ensaio, e dos textos de Wisnik de um modo geral, é possível identificar a ideia implícita de uma certa brasilidade que existiria como uma "corrente

\footnotetext{
155Por exemplo, os ensaios Algumas questões de música e política no Brasil (1987); A Gaia ciência: literatura e música popular no Brasil (1995); Cajuína transcendental (1996) entre outros, reunidos com breves comentários do autor, que os situam em seu contexto, no livro: Sem receita: ensaios e canções. São Paulo: Publifolha, 2004.

156 Escrito originalmente para TERESA: revista de literatura brasileira (São Paulo: USP/Editora 34, no 4 e 5, 2004), o ensaio Machado Maxixe: o caso Pestana também encontra-se em Sem receita: ensaios e canções e foi publicado em livro homônimo pela Editora Publifolha em 2008.

157 WISNIK, José Miguel. Machado Maxixe: o caso Pestana. Sem receita: ensaios e canções. São Paulo: Publifolha, 2004 , p. 79.

158 ASSIS, Machado de. Um homem célebre. Publicado originalmente na Gazeta de Notícias em 1888. Disponível em: <http://machado.mec.gov.br/arquivos/html/contos/macn005.htm>.

159 WISNIK, José Miguel. Op. cit.., p. 24.

160 Ibidem, pp. 32-34.
} 
subterrânea", sempre prestes a aflorar naturalmente e que viria a conectar os diversos domínios da vida cultural brasileira. Esta noção de uma certa brasilidade, um elemento indefinido de caráter nacional, já se encontrava em Dança Dramática, na metáfora da existência de um túnel (correntes subterrâneas) que ligaria distintas "dimensões da vida cultural" brasileira e que seria o caminho pelo qual passava "grande parte das discussões envolvendo arte e sociedade" no Brasil. ${ }^{161}$ Esta visão, no entanto, merece uma reflexão crítica, na medida em que a existência de uma brasilidade latente, em certo sentido, dilui as tensões e contradições do processo histórico de formação da cultura brasileira. 0 conjunto da obra ensaística de Wisnik constitui uma teoria sóciohistórica sobre a música e a cultura brasileira no qual tem destaque a canção popular.

O nome de Wisnik muitas vezes aparece associado ao de Luiz Tatit, uma vez que ambos, músicos e pesquisadores, estudam a canção popular em linhas de pesquisa que consideram o texto literário em suas relações intrínsecas com o texto musical, em trabalhos que, ainda que com distintas abordagens e enfoques teórico-metodológicos, podem ser considerados complementares. Luiz Tatit, após sua graduação em Música pela ECA, desenvolveu paralelamente as carreiras de cancionista (termo que ele mesmo cunhou) e de pesquisador acadêmico na área de Linguística, cujo foco dos estudos esteve na construção de uma teoria semiótica da formação do sentido na canção popular. Apesar da ampla repercussão de seus trabalhos, referência para pesquisas em diversas áreas e textos fundamentais para se entender o que vem a ser a canção popular, seus estudos têm um foco textual que não considera necessária a abordagem dos elementos externos (contexto), razão pela qual não teve maior impacto na historiografia, ao menos dentro da periodização deste estudo. 0 autor apresentou uma leitura da história da canção brasileira a partir de sua perspectiva semiótica no livro $O$ Século da Canção. ${ }^{162}$ Wisnik, comentando este paralelo entre seus trabalhos e os de Tatit, enquanto músicos, compositores e pensadores da canção brasileira, considera que ambos formam um "espelhamento machadiano", uma afinidade enorme que se faz através de uma oposição simétrica, na trajetória de ambos e na maneira de trabalhar. ${ }^{163}$ De fato, enquanto Wisnik tem uma forma muito particular de elaboração de seu

\footnotetext{
161 WISNIK. José Miguel. Dança dramática. Tese de doutorado em Letras. FFLCH-USP, 1979, p. II. 162 TATIT,Luiz. O século da canção. Cotia: Ateliê Editorial, 2004.

163 WISNIK, José Miguel. Sem receita: ensaios e canções. São Paulo: Publifolha, 2004, p. 455.
} 
pensamento e desenvolvimento de seus trabalhos, Tatit caminhou, desde suas primeiras pesquisas, na direção da construção de um modelo teórico para abordagem de seu objeto, que vem sendo aplicado por uma corrente de semioticistas afinados com sua linha de pesquisa. Recentemente ambos lançaram livros que incluem ensaios, canções e entrevista. Talvez não por acaso o livro de Wisnik se chame Sem receita e o de Tatit, Todos entoam. ${ }^{164}$

\subsubsection{Contier: nova relação entre história e música}

Entre os três autores aqui indicados como referências fundamentais para as primeiras pesquisas historiográficas sobre música popular, Arnaldo Contier é o único historiador de ofício ligado ao meio acadêmico. Teve formação musical na linha da tradição artística européia, que é o que se ensinava nos conservatórios na época de sua formação, ainda que seu instrumento, o acordeom, tenha presença significativa na música popular no Brasil. Ampliou seu horizonte de informações musicais através de seus próprios estudos, incorporando a produção das vanguardas musicais do século XX, que pouca ou nenhuma atenção tinha nos cursos tradicionais, e vai iniciar em sua atividade docente suas reflexões sobre a história da música no Brasil. ${ }^{165}$

A importância de Contier na pesquisa sobre música na área de História reside tanto na afirmação do objeto dentro da disciplina num momento em que temas como arte e questões culturais ainda não estavam contemplados na pesquisa histórica, como também no seu papel de formador de diversos pesquisadores do campo. Em um momento em que os fóruns para o debate sobre música popular na universidade eram escassos e o objeto ainda não estava consolidado no campo acadêmico, Contier promoveu seminários sobre o tema que muito contribuíram para a formação de pesquisadores que hoje são referência no assunto e orientou diversas pesquisas sobre música na área de História. Segundo Vinci de Moraes, ele foi por muito tempo uma espécie de solista na formação de pesquisadores e na evolução deste novo campo de pesquisa. ${ }^{166}$

164 TATIT, Luiz. Todos entoam: ensaios, conversas e canções. São Paulo: Publifolha, 2007.

165 Uma breve explanação sobre sua formação musical e trajetória de pesquisador encontra-se em entrevista publicada em: REVISTA DE HISTÓRIA. Departamento de História da FFLCH-USP. São Paulo: Humanitas/FFLCH-USP, no 157,2 o semestre de 2007, p. 173-192.

166 REVISTA DE HISTÓRIA. Departamento de História da FFLCH-USP. São Paulo: Humanitas/FFLCH-USP, no 157, $2^{\circ}$ semestre de 2007, p.9. 
Suas primeiras reflexões ainda estavam centradas no campo de produção erudito, do qual o autor é oriundo. Publicou em 1980 o livro Música e ideologia no Brasil,167 onde analisa a música erudita brasileira entre 1922 e 1965 e a construção do mito do nacionalismo musical no Brasil. Mas é na sua tese de livre docência Brasil Novo: música, nação e modernidade. Os anos 20 e 30, que Contier irá apresentar de maneira consistente e num patamar superior, sua leitura crítica do nacionalismo musical brasileiro, seus estudos das relações entre música e política e apontar "as fortes marcas ideológicas que permearam toda a produção musical brasileira nos anos 1920 e 1930". ${ }^{168}$ Trabalho de fôlego, empreendido por um pesquisador já experiente quando da sua realização, embora trate das relações entre música e política no Brasil de um modo geral e com o foco principal na música erudita, aborda também aspectos ligados à música popular urbana no Rio de Janeiro, particularmente o choro. Este trabalho tornou-se uma referência para pesquisas envolvendo as relações entre música e política a partir da análise do material formal.

Contier analisa o surgimento do nacionalismo musical, projeto que, aliando a temática nacionalista à estética européia "preconizava, de um lado, a pesquisa das canções folclóricas, caracterizadas como as falas do povo e, de outro, a atualização do código, da linguagem, conforme pressupostos estéticos internacionais". Considerando o que tinha sido a música brasileira até o limiar do século $\mathrm{XX}$, esse projeto "apresentava uma certa renovação linguística, sem, contudo, defender quaisquer tipos de radicalismos, vistos como algo exterior à realidade histórica brasileira".169 0 autor mostra como, num primeiro momento, os "intelectuais envolvidos com a estética nacionalista negavam possíveis relações entre a música e a política”.170 0 projeto, entretanto, chocava-se com "contradições socioculturais daquele momento" histórico, tendo sido "combatido por empresários e setores do público", 171 uma vez que era alto o consumo de cultura estrangeira por parte setores das elites da sociedade da época, dentro da perspectiva de inserir o país no concerto das nações "civilizadas". Segundo Contier, "durante a década de 1920, o sonho da concretização dos ideais dos músicos nacionalistas esbarrava no gosto da elite dominante, acostumada à música universal, de

167 CONTIER, Arnaldo Daraya. Música e ideologia no Brasil. 2ª ed. revista e ampliada. São Paulo: Novas Metas, 1985. Primeira edição lançada em 1980.

168 CONTIER, Arnaldo Daraya. Brasil Novo: música, nação e modernidade. Os anos 20 e 30. Tese de livre docência. FFLCH-USP, 1988. P. IX.

169 Ibidem, p. 5-6.

170 Ibidem, p. I.

171 Ibidem, p. II. 
tendência cosmopolita e apegada ao romantismo musical". Por essa razão, os intelectuais do nacionalismo musical "começaram a criticar o governo liberal da Velha República, passando a eleger o Estado como o único agente capaz de apoiar um projeto nacionalista de grande envergadura no campo da música". Até então, "o nacionalismo musical, no Brasil, nunca havia revelado uma coloração política muito definida". Mas, dentro deste contexto, "a Revolução de 1930 foi saudada pelos compositores e intelectuais - excetuando-se Mário de Andrade - com vivas de entusiasmo e esperança". ${ }^{172}$

Contier mostra como "o projeto nacionalista no campo musical, em sua essência, objetivava homogeneizar o social, o cultural, como exercício de poder de um grupo que se julgava o único agente capaz de interpretar a História da Cultura no Brasil. Em sua interpretação, "a construção do discurso nacionalista na música, refletiu, intrinsecamente, o sufocamento de outras falas, no campo da música, ligadas ao proletariado urbano, a movimentos anarquistas, à música carnavalesca como símbolo de outra ordem ou, ainda, à própria música internacional". ${ }^{173}$ "Os compositores e intelectuais ligados ao projeto nacionalista mitificaram o Estado como o sujeito da história". 174 "No entanto, esse Estado nacional-populista terminou por não se interessar pelo projeto modernista em sua totalidade". O Estado Novo acabou endossando somente os projetos de fácil execução e que exigiam pequenas verbas, como o programa de canto orfeônico apresentado por Villa-Lobos. ${ }^{175}$

Arnaldo Contier mostra como, "dentro desse quadro, A Hora do Brasil foi saudada com entusiasmo pelos músicos, pois representava um programa oficial em defesa da música erudita que vinha perdendo o seu prestígio com a democratização do rádio durante os anos 1930". "A censura era vista com bons olhos pelos autores eruditos, pois esses artistas sentiam certa repulsa em face da música vulgar. Somente Pixinguinha, Noel Rosa, Nazareth e mais uns dois ou três compositores populares foram aceitos pelos artistas eruditos; os demais foram completamente ignorados pelos historiadores da música brasileira". ${ }^{176}$ Mas “o Estado Novo não elaborou um projeto cultural hegemônico capaz de controlar ou de perseguir artistas que apresentassem propostas estéticas diametralmente opostas, como fizeram outros regimes totalitários".

\footnotetext{
172 Ibidem, pp. 217-221.

173 Ibidem, p. 201.

174 Ibidem, p. 233.

175 Ibidem, p. 234.

176 Ibidem, p. 322-325.
} 
“O estado, através do DIP, somente censurou letras de músicas populares consideradas ofensivas à moral e aos bons costumes ou que pudessem incutir, nos jovens, ideias ligadas à malandragem, incompatíveis com a ideologia estadonovista". ${ }^{177} 0$ autor conclui desta análise que "a questão nacional no campo da música não foi o resultado de um projeto estruturado de cima para baixo, isto é, não se tratou de uma estratégia de dominação do estado, mas, do produto de uma ampla polêmica iniciada nos fins do século XIX, a qual reuniu" intelectuais e compositores interessados na incorporação de temas populares na música erudita e também representantes do campo de produção popular. ${ }^{178}$

Marcos Napolitano aponta princípios metodológicos propostos por Contier que influenciaram a sua tese de doutorado:

a. 0 princípio da descontinuidade histórica e a crítica das origens.

b. Tensão entre a memória canônica e a história crítica, frequentemente cotejadas no mesmo trabalho historiográfico.

c. Valorização da experiência da escuta como método de análise da canção. A escuta de quem escreveu sobre a história da música; a escuta do pesquisador que busca romper com o legado historiográfico; a escuta do próprio performer da canção.

d. A valorização de uma tensão básica, a qual deveria ser explorada criticamente, a saber: a história da música como organização dos sons com base em princípios estéticos, confrontada com a história do pensamento sobre a música, com base no conceito de "escuta ideológica".179

Contier publicou também diversos artigos e comunicações com questões relevantes para os estudos históricos da música. Entre estes textos, tiveram grande repercussão os artigos Música e História180 e Música no Brasil: História e interdisciplinaridade. Algumas interpretações (1926-1980)181, que apresentaram um estado do conhecimento das relações ente história e música por volta do momento de sua publicação e apontaram questões metodológicas para futuras pesquisas.

\footnotetext{
177 Ibidem, p. 338. Em nota, Contier remete o leitor, para discussão destas ideias, a: TOTA, Antonio Pedro. Samba da legitimidade. Dissertação de mestrado em História. São Paulo: FFLCH-USP, 1980; MATOS, Claudia Neiva. Acertei no milhar: samba e malandragem no tempo de Getúlio. Rio de Janeiro: Paz e Terra, 1982; WISNIK, José Miguel. Getúlio da paixão cearense (Villa-Lobos e o Estado Novo). In: SQUEFF; WISNIK. Música: o nacional e o popular na cultura brasileira. São Paulo: Brasiliense, 1982.

178 Ibidem, p. 297-298.

179 NAPOLITANO, Marcos. História e música popular: um mapa de leituras e questões. In: REVISTA DE HISTÓRIA. Departamento de História da FFLCH-USP. São Paulo: Humanitas/FFLCH-USP, no 157, 2007, p. 161.

180 CONTIER, Arnaldo Daraya. História e música. Revista de História. São Paulo: FFLCH/USP, no 119 (nova série), p. 69-89, 1988.

181 CONTIER, Arnaldo Daraya. Música no Brasil: História e interdisciplinaridade. Algumas interpretações (19261980). In: Revista História em Debate. Anais do XVI Simpósio da ANPUH, 1991, pp. 151-189.
} 
Na revisão da bibliografia até aqui apresentada, procurei traçar, em linhas gerais, o estado da arte do pensamento sobre a música popular urbana no Brasil no momento em que se iniciam os estudos na área de História. A narrativa histórica de longa duração mais organizada e consistente era aquela oferecida pelos memorialistas e historiadores não acadêmicos. Os textos que melhor expressam esta visão são os livros de José Ramos Tinhorão, Pequena História da música popular brasileira182, lançado inicialmente em 1974 com posteriores atualizações, e, anos depois, História social da música popular brasileira ${ }^{183}$. Uma outra vertente, era a produção que se desenvolvia nos cursos de Letras e Comunicação e também Sociologia. Esta produção, embora construísse também narrativas históricas, este não era o foco principal das pesquisas, além do que tratava-se de estudos pioneiros e o conhecimento histórico nestas linhas estava bastante fragmentado. A Musicologia, dominada pela corrente do nacionalismo musical até a década de 1960, em que pese a quebra da hegemonia desta corrente com a ação das vanguardas, até os anos 1980 ainda não havia tomado a moderna música popular urbana como um objeto de estudo. Isto iria ocorrer somente com a renovação da(s) musicologia(s) em suas distintas vertentes a partir dos anos 1980, questão que será abordada mais detalhadamente no Capítulo 6.

Desta forma, pode-se afirmar que não existia um quadro geral, uma visão panorâmica amplamente aceita nos meios acadêmicos, que fosse uma referência para pesquisas que iriam estudar aspectos mais específicos. Ou melhor, existia uma concepção da história da música popular no Brasil, aquela construída pela corrente historiográfica não acadêmica, a ser submetida à avaliação crítica, questionada nos paradigmas historiográficos em que se fundamentava, e confrontada com a busca de novas fontes, novos olhares para o objeto e a utilização de outros referenciais teóricometodológicos dentro de linhas de pesquisa e abordagens mais atualizadas.

182 TINHORÃO, José Ramos. Pequena história da música popular brasileira. Petrópolis: Vozes, 1974.

183 TINHORÃO, José Ramos. História social da música popular brasileira. São Paulo: Editora 34, 1998. Primeira edição portuguesa: Lisboa, Editorial Caminho, 1990. 


\section{CAPÍTULO 3}

\section{MAPA DA PRODUÇÃO NA ÁREA DE HISTÓRIA}

0 primeiro estudo acadêmico realizado na pós-graduação na área de História sobre música popular urbana no Brasil foi defendido em 1980. Teriam que passar mais seis anos para que a área produzisse outro trabalho de pós-graduação com tema relacionado à música popular. No período que vai de 1980 a 1999 foram encontrados 35 trabalhos, sendo 27 dissertações de mestrado, 6 teses de doutorado e 2 de livre docência (conforme fichas no Anexo), realizados na área de História em São Paulo e no Rio de Janeiro, que são fundadores de uma historiografia acadêmica desenvolvida em programas de pós-graduação em História. Entretanto, assim como ocorrera no período anterior, diversos estudos realizados em outras áreas tangenciaram questões pertinentes à história da música popular no Brasil e alguns destes apresentaram inclusive narrativas históricas estruturadas. 0 foco deste estudo está na produção realizada na área de História e as fontes primordiais são as 35 dissertações e teses relacionadas. Mas, na análise desta produção, irei observar também trabalhos de perfil historiográfico realizados em outras áreas, especialmente aqueles que tiveram maior repercussão no campo dos estudos da música popular. As dissertações e teses de outras áreas mencionadas neste estudo estão listadas nas referências desta pesquisa.

Ao contrário do que ocorreu no período anterior, uma concentração dos temas nos eventos então recentes (o advento da bossa nova, da MPB e da tropicália e as transformações na indústria e no mercado), por um lado, e temas relacionados ao samba carioca, por outro, nos trabalhos da área de História nas décadas de 1980 e 1990 existe uma maior diversidade de objetos e abordagens. Encontramos aqui pesquisas sobre o surgimento de uma música urbana popular no Rio de Janeiro e em São Paulo, sobre o personagem do malandro e seu papel social, estudos envolvendo música e política, geralmente com a periodização na Era Vargas ou nos anos 1960, pesquisas em torno de gêneros de música popular, envolvendo samba, bossa nova, MPB, jovem guarda, tropicália, vanguarda paulista, música sertaneja e rock. Existem também trabalhos estruturados em torno da trajetória artística de compositores como Luiz Gonzaga, Chico Buarque, Custódio Mesquita, Chiquinha Gonzaga, Raul Seixas, Jorge 
Goulart e Nora Ney. Temos ainda pesquisas sobre o rádio nas cidades do Rio de Janeiro e de São Paulo, que, em maior ou menor grau, tangenciam a história da música popular. Naturalmente, cada trabalho apresenta um leque de questões relacionadas ao seu objeto e tem um caráter único que torna difícil e imprecisa qualquer classificação.

Entretanto, para facilitar um olhar panorâmico para a produção, faremos a seguir uma breve apresentação da produção, agrupando os trabalhos naquelas que parecem ser as principais linhas temáticas de pesquisa, destacando seus temas e conclusões em linhas gerais. ${ }^{184}$ Por estar organizada em torno da temática dos trabalhos, esta apresentação não seguirá a cronologia da produção.

\subsection{A PESQUISA SOBRE AS “ORIGENS”: MOMENTO FORMATIVO DA MÚSICA POPULAR NO BRASIL}

Alguns trabalhos situam sua periodização no final do século XIX e começo do século XX, momento de formação e consolidação dos primeiros gêneros de música popular urbana no Brasil. Em Os tangos brasileiros. Rio de Janeiro: 1870-1920, Paulo Roberto Peloso Augusto aborda o surgimento de novos gêneros musicais na cidade do Rio de Janeiro, no período determinado, com enfoque nos tangos brasileiros - que ele utiliza no plural, "pela pluralidade de interpretações válidas" a partir dos diversos elementos rítmicos e sociais que entraram em sua composição - e suas conexões com o maxixe e a habanera. Segundo o autor, os tangos brasileiros não somente encobriam "os ritmos proibidos do maxixe", interpretação que se tornou um certo senso comum sobre o gênero, mas também representaram "outras vertentes formais, como a havanera, com células rítmicas sincopadas, próprias da música brasileira", tendo o nome tango brasileiro sido "dado ainda, indistintamente, a novos gêneros formais que surgiram no início do século XX". Peloso Augusto reúne informações documentais sobre as origens do tango e da habanera. Em sua narrativa, esta última, popularizada em Havana, logo difundiu-se pela Espanha. Seu ritmo característico no

\footnotetext{
184 Nesta apresentação dos trabalhos procurei localizar nos próprios textos passagens em que os autores explicitam as teses centrais de suas pesquisas, e, sempre que possível, articular no meu texto estes trechos nos quais os próprios autores expõe suas ideias, com o objetivo de ser o mais fiel possível a elas, o que resultou em muitas citações. Uma vez que todos os trabalhos estão explicitamente mencionados, e é deles que se está falando, as referências foram agrupadas ao final dos parágrafos, para não poluir demais o texto e dificultar a leitura.
} 
acompanhamento era o mesmo do tango, este na origem uma dança mexicana, que se diferenciava basicamente da habanera apenas pela variação no andamento. Em fins da década de 1920, "a larga divulgação do tango argentino" no Rio de Janeiro "contribuiu para que o tango brasileiro, pouco a pouco desaparecesse, dada a ambiguidade do nome com aquela dança". Por volta desse período, "o surgimento do samba despertou a preferência entre as camadas subalternas". ${ }^{185}$

Este é o único trabalho na área de História, no período que estamos analisando, a ter o foco central neste momento criativo da música popular no Rio de Janeiro. Não por acaso, a tese de Peloso Augusto tem uma abordagem que tende para a Musicologia. O tema do surgimento dos gêneros de música popular carioca no final do século XIX sempre despertou mais o interesse dos músicos, no meio dos quais é forte a tendência a discutir a origem destes primeiros gêneros de música popular brasileira e buscar denominações e definições precisas de elementos estruturais que os diferenciem, tarefa difícil e nem sempre viável. Conforme já observado, a Musicologia sempre incorporou estes primeiros gêneros de música brasileira como seu objeto de estudo, ainda que a incorporação dos gêneros que os sucederam e se constituíram em estreita ligação com o mercado seja um fenômeno mais recente. Assim, a pesquisa de Peloso Augusto veio soma-se a outros esforços empreendidos até então com o objetivo de compreender estes primeiros gêneros de música urbana popular no Brasil até então realizados na área de Música, a exemplo de A influência da habanera nos tangos de Ernesto Nazareth ${ }^{186}$, ou mesmo em outras áreas, como Choro: a construção de um estilo musical $^{187}$. Em Feitiço Decente ${ }^{188}$, Carlos Sandroni apresenta uma elaboração que se constituiu numa importante contribuição sobre a questão. 0 autor considera que os ritmos da habanera e do tango, assim como dos gêneros musicais brasileiros no final do século XIX, são variações surgidas nas Américas de uma estrutura fundamental derivada das concepções rítmicas da música africana. Assim, para o autor, "lundu,

185 AUGUSTO, Paulo Roberto Peloso. Os tangos brasileiros: Rio de Janeiro: 1870-1920. Tese de doutorado em História, FFLCH-USP, 1996, pp. 142-144. Obs: o autor prefere grafar com "v": havanera. O aportuguesamento da palavra também pode ser "havaneira". As três formas - habanera, havanera e havaneira - encontram-se dicionarizadas.

186 NASCIMENTO, Antonio Adriano. A influência da habanera nos tangos de Ernesto Nazareth. Dissertação de mestrado em Artes. São Paulo: ECA-USP, 1990.

187 PUTERMAN, Paulo Marcos. Choro: a construção de um estilo musical. Dissertação de mestrado em Sociologia. FFLCH-USP, 1985.

188 SANDRONI, Carlos. Feitiço decente: transformações do samba no Rio de Janeiro (1917-1933). Rio de Janeiro: Zahar/UFRJ, 2001. Versão resumida e modificada da tese de doutorado defendida em 1997 na Universidade François Rebelais de Tours, França. 
polca-lundu, cateretê, fado, chula, tango, habanera, maxixe e todas as combinações destes nomes, embora em outros contextos possam ter determinações próprias, quando estampados nas capas das partituras brasileiras do século XIX, nos informavam basicamente que se tratava de música 'sincopada', 'tipicamente brasileira'”. ${ }^{189}$

A historiografia tradicional da música no Brasil havia, até então, observado este período formativo da música popular urbana no Brasil com o foco na vida musical da cidade do Rio de Janeiro. Em As sonoridades paulistanas: a música popular na cidade de São Paulo. Final do século XIX ao início do XX'190, José Geraldo Vinci de Moraes coloca o foco na cidade de São Paulo. A pesquisa teve por objetivo estudar o processo de construção e constituição da música popular urbana paulistana, entre o final do século XIX e o final da década de 1920. Com atenção para as "singularidades geradas" nas tramas histórico-sociais, Vinci de Moraes procura perceber, "de um lado as contribuições que esse processo possa ter dado à instituição da música popular brasileira, e, de outro, como os ritmos e sons da música popular brasileira, já consolidados, influíram na produção da música urbana em São Paulo”.191 Por sua temática, abordagem na perspectiva da história cultural e pesquisa de fontes primárias, este trabalho inovou em relação àquilo que vinha sendo feito de um modo geral em termos de narrativa histórica da música popular no Brasil, especialmente por não centrar a pesquisa na formação e desdobramentos da música carioca como música brasileira. Vinci daria continuidade a este estudo em sua tese de doutorado Metrópole em Sinfonia: história, cultura e música popular em São Paulo nos anos 30. Neste estudo, o autor mostra como, num momento de grandes transformações numa cidade que passou da condição de provinciana à de metrópole moderna, três fatores incidiram na formação de uma poética musical paulistana diversificada e eclética: "o ritmo intenso e contínuo de mudanças da cidade, a nostalgia dos imigrantes e desenraizados de todos os tipos e as tradições sertanejas". ${ }^{192}$ Estes elementos contribuíram no desenvolvimento de uma música paulistana que a historiografia tendia a não considerar relevante na constituição do que se chama genericamente de música

\footnotetext{
189 Ibidem, p. 31.

190 MORAES, José Geraldo Vinci de. As sonoridades paulistanas: a música popular na cidade de São Paulo. Final do século XIX ao início do XX . Dissertação de mestrado em História. São Paulo. PUC-SP, 1989.

191 Ibidem, p. vi.

192 MORAES, José Geraldo Vinci de. Metrópole em Sinfonia: história, cultura e música popular em São Paulo nos anos 30. Tese de doutorado em História. São Paulo: FFLCH-USP. 1997, p. 251.
} 
popular brasileira. Vinci analisa como o samba paulistano não conseguiu se afirmar no meio urbano, restringiu-se a comunidades e seu espaço social foi sendo ocupado por uma música mais aproximada ao padrão do samba carioca. Estuda também o papel do rádio, como polo principal dos circuitos de produção e difusão cultural, na formação das sonoridades que compuseram a polifonia da cidade.

Precederam as pesquisas de Vinci de Moraes duas pesquisas realizadas em outras áreas sobre a música na cidade de São Paulo entre 1900 e 1930. 0 primeiro deles, Samba na cidade de São Paulo (1900-1930): contribuição ao estudo da resistência e da repressão cultural, de Iêda Marques Britto Hori. Este trabalho, embora realizado na área de Ciências Sociais, tem perfil historiográfico: um recorte temporal, um problema histórico e uma narrativa como resposta. Segundo a autora, o trabalho "tem como finalidade maior contribuir para o estudo da resistência e da repressão cultural, ocupando-se de manifestações culturais desenvolvidas e mantidas por segmentos populacionais negros e mulatos ocorridas na cidade de São Paulo no período 19001930." Como esse objetivo, buscou a reconstituição "de algumas destas manifestações, procurando delimitar os grupos sociais envolvidos, sua distribuição espacial, e, sobretudo, as circunstâncias em que tais processos se realizaram", importando-se igualmente em "conhecer as reações surgidas ante tais manifestações, não só da população considerada como um todo, mas também e principalmente, por parte das camadas dirigentes". ${ }^{193}$ A outra pesquisa a abordar a cidade de São Paulo no início do século XX foi Música na Cidade em Tempo de Transformação: São Paulo, 1900-1930, de Alberto Ikeda. Este trabalho também apresenta perfil historiográfico, na medida em que se propõe "responder a indagações decorrentes da constatação das pouquíssimas citações à cidade de São Paulo na historiografia da música popular no Brasil". A partir da percepção de que a capital paulista atravessou neste período grandes modificações urbanas, Ikeda investiga "qual teria sido a 'vida' artístico-musical na cidade nesse período", a ausência de destaque a artistas populares paulistas nos estudos de história da música popular e a própria ausência da música nos estudos sobre a história de São Paulo. ${ }^{194}$ Trata-se de uma pesquisa historiográfica feita por um músico, sem muitas

\footnotetext{
193 HORI, Iêda Marques Britto. Samba na cidade de São Paulo (1900-1930): contribuição ao estudo da resistência e da repressão cultural. Dissertação de mestrado em Ciências Sociais. São Paulo: FFLCH-USP, 1981, p. 3-4.

194 IKEDA, Alberto Tsuyoshi. Música na Cidade em Tempo de Transformação: São Paulo, 1900-1930. Dissertação de mestrado em Artes. São Paulo: ECA-USP, 1988, p. 1-2.
} 
referências diretas ao instrumental teórico próprio da História, mas com perspectiva crítica no trato com as fontes e documentos. ${ }^{195}$

Um aspecto mais especifico deste momento formativo é o do desenvolvimento da prática instrumental e a possível formação de escolas técnico-estéticas em determinados instrumentos, tema interessante e pouco estudado, ao menos numa perspectiva historiográfica. 0 trabalho de Sérgio Estephan, $O$ violão instrumental brasileiro: 1884-1924, aborda um período de afirmação do violão, instrumento fundamental na música brasileira, tanto naquela chamada de concerto quanto na música popular, e dá destaque para violonistas que seriam fundadores de uma "escola" do violão popular brasileiro: Quincas Laranjeiras, João Pernambuco, Américo Jacomino (Canhoto) e também Heitor Villa-Lobos. Para Estephan, o contato de Villa-Lobos "com os músicos populares do Rio de Janeiro, com a música brasileira do caboclo, do sertanejo, com a musicalidade das selvas brasileiras, enriqueceu o universo técnico e composicional do violão brasileiro, com contribuições ainda não plenamente incorporadas pelo violão contemporâneo".196 Apesar de focado no violão, o trabalho também destaca compositores e instrumentistas como Ernesto Nazaré, Chiquinha Gonzaga e Anacleto de Medeiros, com o objetivo de melhor caracterizar "aspectos da musicalidade do período". ${ }^{197}$

\subsection{HISTORIOGRAFIA DO SAMBA}

A historiografia do samba constitui um caso à parte. Foi fundamentalmente em torno do gênero - o samba carioca elevado à condição de música nacional - que se estruturou toda uma corrente de memorialistas, jornalistas, colecionadores, pesquisadores e historiadores, em estreita relação com o campo de produção, conforme

\footnotetext{
195 Em 1995 Ikeda defendeu sua tese de doutorado em Comunicação, também na ECA-USP: Música política: imanência do social. Com o tempo, Alberto Ikeda desenvolveria estudos de abordagem etnomusicológica e se tornaria uma dos mais respeitados pesquisadores do campo no país.

196 ESTEPHAN, Sérgio. O violão instrumental brasileiro: 1884-1924. Dissertação de mestrado em História. São Paulo: PUC-SP, 1999, p. 4.

197 Em 2007, Estephan defendeu a tese de doutorado Viola, minha viola: a obra violonística de Américo Jacomino, o Canhoto (1889-1928), na cidade de São Paulo, PUC-SP. A obra de Canhoto também foi estudada em ANTUNES, Gilson Uehara. Américo Jacomino "Canhoto" e o desenvolvimento da arte solística do violão na cidade de São Paulo. Dissertação de mestrado em Artes, ECA-USP, 2003. Ainda sobre a história do violão ver, BARTOLONI, Giácomo. $O$ Violão na cidade de São Paulo no período de 1900 a 1950. Dissertação de mestrado em Artes. IA-UNESP, 1995 e História, violão: a imagem que fez escola. Tese de doutorado em História. UNESP, 2000.
} 
discutido no Capítulo 1. Da mesma forma, parcela significativa do ensaísmo acadêmico dos anos 1970 estava voltada para o gênero, sua constituição, relações político-sociais, seu desenvolvimento ulterior e impasses do momento. Ou seja, é em torno do samba que se pode identificar de maneira mais delineada um sistema integrado de autores, obras, público e intérpretes. Wisnik apontou que, já por volta do final do século XIX, estruturava-se um sistema deste tipo em torno da polca em processo de transformação para o objeto sincrético que seriam os primeiros gêneros de música popular no Brasil. ${ }^{198}$ Ou seja, a música popular no país foi se constituindo como sistema desde seus primórdios. Mas em torno do samba fica mais evidente este processo de formação de um sistema simbólico que, a partir da década de 1930, inter-relacionou os compositores, suas canções, o público, intérpretes, crítica, memorialistas, produtores e historiadores do gênero.

Assim, as pesquisas em torno deste objeto já partiram de um conhecimento acumulado, de uma bibliografia básica quase obrigatória e de narrativas instituídas com as quais tinham que dialogar, incluindo as pesquisas acadêmicas que vinham se desenvolvendo na área de Letras. Da mesma forma, se o samba dispunha de referências, fontes e um acervo mais acessível e organizado, produto da atividade de seus estudiosos desde a década de 1930, por outro lado, se impunha uma leitura crítica desse material e a necessidade de um cruzamento com outras fontes a serem levantadas no curso das pesquisas.

Entre os trabalhos do período que sob algum aspecto podem ser enquadrados como historiografia do samba, duas questões estiveram em foco: as relações da canção popular com o governo Vargas e o tema da malandragem. 0 imaginário popular, e também o erudito e acadêmico, em torno da malandragem, com presença marcante na cultura brasileira, coloca o tema como objeto de estudo para as ciências humanas de um modo geral. É natural que tenha certo destaque na historiografia do samba, uma vez que a figura do malandro carioca está intrínseca e historicamente relacionada ao mundo do samba. Já os trabalhos voltados para o estudo das relações entre samba e política no Estado Novo, além de serem parte da historiografia do samba, também se situam numa linha de pesquisa sobre música e política, que será abordada adiante.

198 WISNIK, José Miguel. Machado maxixe: o caso Pestana. In: TERESA. São Paulo: Editora 34, no 4 e 5, 2003, p. 27. 
Este é o caso de Samba da Legitimidade, de Antonio Pedro Tota, trabalho que inaugura a pesquisa sobre música popular na pós-graduação na área de História, no qual os dois temas acima mencionados já se encontram presentes. Segundo o autor, o trabalho "tem por fim demonstrar que o Estado autoritário instituído pelo golpe de 1937 por Getúlio Vargas, se utilizou da canção popular, mais precisamente de alguns gêneros dela, para veicular a ideologia do trabalhismo, necessária para que se processasse sua legitimação". Discute como se deu essa utilização analisando duas hipóteses: a cooptação indireta dos compositores, através da ideologia trabalhista, sem necessidade de mediação direta dos organismos do estado; ou a hipótese da cooptação direta através de "recomendações", proposição que o autor localizou na obra de Tinhorão. Nesta segunda hipótese, o Departamento de Imprensa e Propaganda (DIP) agiria diretamente sobre os compositores, incentivando a produção de canções com valoração positiva sobre o trabalho e recomendando o abandono da apologia da malandragem. ${ }^{199}$ Na sua pesquisa, Antonio Pedro concluiu que não havia necessidade de mediação direta dos organismos do Estado Novo para que os compositores populares produzissem canções ideologicamente afinadas com o trabalhismo, ou seja, tratava-se de uma cooptação indireta. Antonio Pedro se utiliza das proposições de José de Souza Martins acerca da canção - o universo que verbaliza cantando ${ }^{200}$ - e apóia-se também nas formulações de Antonio Gramsci acerca do popular para elaborar uma definição de canção popular como aquela produzida no meio urbano, de autor conhecido, difundida pelos mais variados veículos, que de uma forma ou de outra tenha por objetivo um determinado mercado. ${ }^{201} 0$ trabalho está localizado num momento de formatação de um objeto de estudo e a definição de canção popular se fazia necessária. 0 estudo, entretanto, ainda se apoia em grande parte na análise do discurso das letras das canções, metodologia então em voga, até mesmo pelos objetivos da pesquisa. Um conceito central em Samba da Legitimidade é o de ideologia, que o autor entendia

199 TOTA, Antonio. Pedro. Samba da Legitimidade. Dissertação de mestrado em História. São Paulo: FFLCH-USP, 1980, p. 8-9. A citação de Tinhorão feita por Antonio Pedro é: TINHORÃO, José Ramos. Música popular: um tema em debate. JCM Editores. RJ, s/d, p. 149. Essa edição, a primeira, financiada pelo autor, é hoje difícil de se encontrar. Na 3a edição, Editora 34, 1997, a passagem está na p.173: “(...) (O Bonde de São Januário, de Wilson Batista e Ataulfo Alves) hoje reconhecido como um clássico do carnaval, revela em sua letra a preocupação doutrinária do Estado Novo, cujas autoridades recomendavam aos compositores que abandonassem o tema da malandragem, estimulando o povo ao trabalho (...)".

200 MARTINS, José de Souza. Música Sertaneja: a dissimulação na linguagem dos humilhados. In: Capitalismo e tradicionalismo. São Paulo: Livraria Pioneira Ed., 1975, p.103.

201 TOTA, Antonio Pedro. Op. cit., pp. 9-10 e 75. 
"como uma concepção de mundo das classes dirigentes a difundir-se para os outros setores da sociedade". 202 A noção de luta de classes, presente no texto, já se esboça nesta definição de ideologia. Para pensar o papel dos intelectuais, o autor tem como referência as formulações de Gramsci, especialmente o conceito de intelectual orgânico. ${ }^{203}$

Este trabalho pioneiro foi bastante citado e certamente serviu de inspiração para outras pesquisas. Embora ele pudesse ser melhor caracterizado como um estudo das relações entre música e política, incluí-o neste item dedicado à historiografia do samba com o intuito de exemplificar como estes primeiros estudos sobre o samba e a canção popular tenderam a focar as relações entre música e política. 0 tema deste trabalho foi retomado em estudos posteriores, que discutiremos no tópico "música e política".204

Ainda que o tema da malandragem apareça, mesmo que de maneira secundária, em todos os trabalhos que abordam a canção popular com periodização entre 1920 e 1950, dois trabalhos colocaram o personagem malandro no centro da pesquisa. Capoeiras e malandros: pedaços de uma sonora tradição popular (1890-1950), de Maria Angela Borges Salvadori, analisa as "experiências urbanas de capoeiras e malandros na cidade do Rio de Janeiro" após o fim da escravidão, utilizando-se da música popular como "eixo documental" principal. Para a autora, os capoeiras do final do século XIX e início do XX e os malandros dos anos 1930 e 1940 "mantiveram uma tradição de luta pela liberdade aprendida desde os tempos da escravidão", preservando assim, "uma margem de autonomia e deliberação sobre suas próprias vidas". Entretanto, "num contexto de valorização moral do trabalho e de exaltação da figura do trabalhador, foram rotulados como sinônimos de vadiagem e violência urbana". Salvadori procura ressaltar, ao longo do texto, "uma prática de vida em que a liberdade pretendia ser preservada",205 alinhavando entre os capoeiras do fim do regime de

\footnotetext{
202 TOTA, Antonio Pedro. Op. cit., p. 12.

203 GRAMSCI, Antonio. Os intelectuais e a organização da cultura. 2 ed. Rio de Janeiro: Civilização Brasileira, 1978; Literatura e vida nacional. 2ª ed. Rio de Janeiro: Civilização Brasileira. 1978.

RJ: Civilização Brasileira, 1968.

204 Em sua pesquisa de doutorado em História, A locomotiva no ar: rádio na cidade de São Paulo (1924/1934), FFLCH-USP, 1987, Antonio Pedro faz uma análise da gênese do rádio inserido nas transformações urbanas de São Paulo e empreende um estudo do grupo urbano paulistano face às alterações apresentadas pela comunicação massiva, tema que apenas tangencia o estudo da música popular.

205 SALVADORI, Maria Angela Borges. Capoeiras e malandros: pedaços de uma sonora tradição popular (1890-1950).

Dissertação de mestrado em História. Campinas: IFCH-UNICAMP, 1990, p. 6-7.
} 
trabalho escravo e os malandros nas primeiras décadas do século XX no Rio de Janeiro, uma tradição que teria ido até por volta de 1950, quando a malandragem começa a ser substituída pela bandidagem.

O tema da malandragem seria retomado por Tiago de Melo Gomes em Lenço no pescoço: o malandro no teatro de revista e na música popular. "Nacional", "popular" e cultura de massas nos anos 1920. Este texto se contrapõe a uma visão do malandro que vinha se cristalizando nos meios acadêmicos, expressa não apenas na dissertação de Salvadori, mas também em pesquisas realizadas na área de Letras, das quais o texto de maior repercussão foi Acertei no Milhar ${ }^{206}$, de Claudia Matos, e outros textos que o autor menciona na revisão da bibliografia. 0 trabalho parte da proposta de descartar tanto "a caracterização do malandro como opositor a projetos de dominação", como "a utilização de letras de música como explicitação de intenções nesse sentido”, prática até então muito utilizada. 0 malandro, para o autor, antes de oposição à ordem constituída, "estaria relacionado a intensas discussões sobre a nacionalidade operadas nos anos 1920". Teria surgido, assim como outros personagens tais como a mulata, o caipira e o português, no teatro de revista, divertimento popular da época, num contexto marcado por duas questões centrais: "as releituras do 'nacional' e do 'popular' e o surgimento e institucionalização da moderna cultura de massas no Brasil". Os sambas de apologia da malandragem teriam aparecido por volta de 1927 em "relação profunda com os personagens análogos" do teatro de revista, em um momento em que o samba foi elevado à condição de símbolo nacional em meio a inúmeros outros gêneros existentes, alguns deles até mais cristalizados na preferência popular, como o maxixe e os gêneros sertanejos. A hipótese do autor é a de que, "em conjunto com questões relacionadas ao desenvolvimento da cultura de massas, como a gravação elétrica, a elevação do samba ao status de símbolo nacional foi fruto de uma valorização dos morros e subúrbios ocorrida no final da década, e a figura do malandro era considerada representativa destes espaços no imaginário daquele período". ${ }^{207}$

Em 1983, é publicado Tia Ciata e a pequena África no Rio de Janeiro ${ }^{208}$, de Roberto Moura, vencedor do concurso de monografias sobre a Tia Ciata realizado pela

\footnotetext{
206 MATOS, Claudia Neiva. Acertei no milhar: samba e malandragem no tempo de Getúlio. Rio de Janeiro: Paz e Terra, 1982.

207 GOMES, Tiago de Melo. Lenço no pescoço: o malandro no teatro de revista e na música popular. "Nacional", "popular" e cultura de massas nos anos 1920. Dissertação de mestrado em História. Campinas: IFCH-UNICAMP, 1998, pp. 5-8.

208 MOURA, Roberto. Tia Ciata e a pequena África no Rio de Janeiro. Rio de Janeiro: FUNARTE, 1983.
} 
FUNARTE. O livro não foi desenvolvido num programa de pós-graduação, mas seu autor é acadêmico, docente e pesquisador da história do cinema brasileiro, com atenção para as representações do Rio de Janeiro no cinema. Este texto, que em torno da figura da baiana Ciata articula uma narrativa para a história do samba carioca, foi um desdobramento destas pesquisas fílmicas sobre o Rio de Janeiro da virada do século. O livro influenciou e contribuiu para a fixação de uma narrativa sobre a história do samba, na qual papel de destaque é atribuído às tias baianas, especialmente Ciata cuja disposiç̧ão e utilização dos cômodos da casa já fora analisada como modelo para se pensar complexas relações socioculturais - e alguns personagens heróicos como Hilário Jovino.

\subsection{MÚSICA E POLÍTICA}

O estudo das relações entre música e política dentro de uma linha de pesquisa da história política foi uma vertente importante dos estudos historiográficos sobre a música popular no período em foco neste estudo. A dissertação de Antonio Pedro Samba da Legitimidade, apresentada como parte da historiografia do samba, é também um estudo de história política, conforme afirmado anteriormente. Mas esta linha de estudos teve um grande impulso com as pesquisas e a atuação docente de Arnaldo Contier, discutida no capítulo anterior.

Nesta linha de pesquisa, as relações entre a canção popular, especialmente o samba, e o primeiro governo de Getúlio Vargas, constituiu-se num objeto privilegiado. Esta incidência de pesquisas neste objeto pode ser atribuída ao cruzamento de diversas séries entre por volta de 1930 e 1945, que inspiraram estudos nesta linha: a elevação do status social do samba carioca, erigido à condição de música nacional; os debates em torno da identidade cultural brasileira; a modernização e industrialização do país; a ampliação do mercado de bens culturais, com destaque para o papel do rádio; o momento da história política do país; e a utilização da música - popular e erudita como instrumento de propaganda política do regime. Ainda que o cruzamento destas séries possa ser localizado nos anos da chamada Era Vargas, especialmente no que diz respeito à conexão dos eventos socioculturais com as políticas da ditadura varguista, 
alguns destes eventos remontam à década de 1920, como podemos deduzir dos estudos de Arnaldo Contier e Tiago de Melo Gomes. Um certo imaginário que se construiu acerca do primeiro governo Vargas, bem de acordo com os interesses políticos do trabalhismo e seus herdeiros, como o momento de construção de um "Brasil Novo", moderno e industrializado, e ponto de afirmação da nacionalidade e de uma identidade cultural, foi decerto um elemento que inspirou os pesquisadores a confrontar essa versão com a pesquisa histórica.

O outro período, em que se concentram os trabalhos que estudam as relações entre música e política, está compreendido entre os anos que vão de 1959, com o surgimento da bossa nova, até 1978, com o fim da censura que se implantou após a radicalização da ditadura militar a partir da edição do AI-5 em dezembro de 1968. Naturalmente, os estudos estão distribuídos em distintas periodizações, dependendo do objeto específico de cada pesquisa. Generalizando, podemos dizer que as periodizações estariam entre 1959 e 1969, se pensamos num momento de importantes transformações no campo de produção musical e nas suas relações com o mercado cultural, ou entre 1968 e 1978, se o objeto principal da análise for a censura do regime militar e as manifestações na canção popular face a essa realidade.

Com sua periodização definida no primeiro governo de Getúlio Vargas, temos $O$ combate ao samba e o samba de combate: música, guerra e política (1930-1945),209 de João Ernani Furtado Filho. O objetivo do autor nesta pesquisa é articular as críticas ao samba e aos demais gêneros de música popular correlatos em torno das questões políticas do período, bem como discutir a utilização desta mesma música popular anteriormente criticada como parte da propaganda governamental em torno da participação do país na $2^{\text {a }}$ Guerra Mundial. Discutindo a posição dos compositores frente a estas questões, vai também abordar temas como a malandragem, o elogio ao trabalho e a censura no Estado Novo. 210

A censura será o tema central de Sinal Fechado: a música popular brasileira sob censura (1937-1945 / 1969-1978), de autoria de Alberto Moby. O trabalho se propõe a

\footnotetext{
${ }^{209}$ FURTADO FILHO, João Ernani. O combate ao samba e o samba de combate: música, guerra e política (1930-1945). Dissertação de mestrado em História. São Paulo: PUC-SP, 1998.

2100 autor deu continuidade a esta pesquisa em sua tese de doutorado em História, FURTADO FILHO, João Ernani. Um Brasil brasileiro: música, política, brasilidade (1930-1945), FFLCH-USP, 2004, já fora da periodização deste estudo.
} 
fazer uma análise comparada do papel da censura no Estado Novo e no regime militar, procurando identificar qual foi a política destes regimes autoritários para a cultura em geral e a música em particular, quais seus objetivos e quais foram as posições dos compositores frente ao regime e à censura. 0 autor procura demonstrar que "Estado Novo e regime militar, embora apresentem propostas semelhantes de Estado-nação baseadas em pressupostos autoritários e antiliberais", "cada um, ao menos no que diz respeito às artes - e à música popular, em particular - tem propostas e práticas bastante distintas”. Assim, para o autor, querer aproximá-las para além de uma generalização enquanto autoritarismos, seria "atropelar as especificidades históricas de cada um dos dois regimes", uma vez que se tratam de "dois 'autoritarismos"' distintos para os quais não se poderia utilizar "os mesmos parâmetros, baseados numa conceituação meramente abstrata de 'autoritarismo' ou de 'ditadura'”. O trabalho de Moby concentra-se na produção da tradição do samba carioca e na MPB, sigla que o autor procura situar dentro de uma perspectiva mais restrita, ao contrário de outros trabalhos precedentes e contemporâneos que usavam a sigla MPB como sinônimo de música popular brasileira, o que não é preciso, como veremos adiante. ${ }^{211}$

A tese de doutorado de Marcos Napolitano, Seguindo a canção: engajamento político e indústria cultural na trajetória da música popular brasileira (1959-1969), também um estudo da história política do período, mas com o foco claramente colocado na música popular, aborda "as diversas formas de engajamento político e crítica cultural assumidas pela canção" popular brasileira "entre o surgimento da bossa nova e a diluição do tropicalismo". O autor apresenta a tese de que a MPB "traduziu projetos e contradições dos artistas e intelectuais envolvidos de alguma forma com o paradigma 'nacional-popular'", entendido "como uma cultura política", ao mesmo tempo em que "esteve no epicentro da reorganização da indústria cultural brasileira, tornando-se um dos seus produtos mais rentáveis".212 Argumenta que, neste processo, a MPB transformou-se numa instituição sociocultural com lugar e espaço social bem

\footnotetext{
211 MOBY, Alberto. Sinal Fechado: a música popular brasileira sob censura (1937-1945/1969-1978), Dissertação de mestrado em História. Niterói: UFF, 1993. Citações retiradas do livro homônimo, 2ª ed. Rio de Janeiro, Apicuri, 2008, pp. 165 e 170.

212 NAPOLITANO, Marcos. Seguindo a canção: engajamento político e indústria cultural na trajetória da música popular brasileira (1959-1969). Tese de doutorado em História. São Paulo: FFLCH-USP, 1999, Resumo.
} 
definido. Este trabalho, assim como outras produções do autor, tornou-se referência importante nos estudos do campo.

Sobre a MPB, temos ainda $A M P B$ em movimento: música, festivais e censura, dissertação de mestrado de Ramon Casas Vilarino. 0 objetivo desta pesquisa foi analisar os primeiros anos da ditadura implantada no Brasil com o golpe militar de 1964. Segundo o autor, a música "tornou-se o fio condutor da análise" por apresentarse "como uma fonte abundante, atrativa e reveladora". 0 autor afirma ter procurado "demonstrar como numa sociedade de classes, cindida entre exploradores e explorados, há uma disputa por posições, lugares e situações, onde o que está em jogo, em última instância, é, de um lado, a permanência ou até o aumento dessa exploração e, de outro, a diminuição ou o fim dessa condição". Assim, o trabalho tem uma perspectiva claramente comprometida com uma posição política de esquerda, que pode ser localizada, por exemplo, na afirmação de que "a MPB é um movimento no interior da música popular brasileira, que travou o bom e necessário combate". ${ }^{213} 0$ trabalho tem uma sequência cronológica de eventos bem organizada, que pode ser útil nesse sentido, mas toda a reflexão sobre eles está centrada na ideia da MPB como resistência à ditadura e à exploração capitalista.

Entre os trabalhos orientados por Arnaldo Contier, encontra-se a tese de doutoramento de Carlos Alberto de Moura Ribeiro Zeron, Fundamentos históricopolíticos da música nova e da música engajada no Brasil a partir de 1962: o salto do tigre de papel, ${ }^{214}$ estudo que também tem o foco nas conexões entre estética musical e projetos políticos e ideológicos, mas num outro momento histórico. Olhando para o campo de produção erudito, a pesquisa investiga as noções de história e política que sustentaram os projetos de política cultural dos músicos da vanguarda dos anos 1960, reunidos em torno do grupo Música Nova, até o seu desdobramento em direção a uma música politicamente engajada. Em função das características do estudo, a música popular vai aparecer de maneira muito secundária na tese, que, entretanto, oferece muitos elementos para se entender as polêmicas estético-políticas das esquerdas nos

213 VILARINO, Ramon Casas. A MPB em movimento: música, festivais e censura. Dissertação de mestrado em História,. São Paulo: PUC-SP, 1998. As citações foram retiradas do prefácio da 5ª edição da publicação do livro homônimo: São Paulo: Olho d'Água, 2006, p. 6-7.

214 ZERON, Carlos Alberto de Moura Ribeiro. Fundamentos histórico-políticos da música nova e da música engajada no Brasil a partir de 1962: o salto do tigre de papel. Dissertação de mestrado em História. São Paulo: FFLCH-USP, 1991. 
anos 1960, que tiveram influência marcante na música popular, e é representativa de um momento da pesquisa sobre música na universidade brasileira.

O foco numa certa linhagem da música popular urbana brasileira articulada em torno do samba e expressa na sigla MPB seria criticado por Paulo Cesar Araújo em Eu não sou cachorro, não: música popular cafona e ditadura militar, dissertação de mestrado defendida na UNIRIO em 1999. O objetivo dessa pesquisa foi analisar a produção musical chamada de "brega" ou "cafona", e discutir suas implicações com o regime militar e a censura. Com a palavra "cafona", o autor se refere "àquela vertente da música popular brasileira consumida pelo público de baixa renda, pouca escolaridade e habitante dos cortiços urbanos, dos barracos de morro e das casas simples dos subúrbios de capitais e cidades do interior"; utiliza a palavra entre aspas porque ela "contém um juízo de valor impregnado de preconceitos" com os quais ele não compartilha. Araújo considera que artistas populares como Paulo Sérgio, Odair José, Benito di Paula e até mesmo a dupla Dom \& Ravel, que ficou fortemente estigmatizada como porta-vozes musicais do regime militar, teriam desempenhado um papel de resistência do ponto de vista político e social, nunca ressaltado, ou simplesmente ignorado pelos analistas, críticos, pesquisadores e historiadores da nossa música, que seriam pródigos em assinalar a "ação de combate e protesto empreendida por diversos compositores da MPB", entendida num sentido mais restrito. Como objetivo não declarado, o autor faz uma revisão da narrativa hegemônica sobre o período. Afirma que "através da análise da construção social da memória é possível identificar de que maneira ficou cristalizada em nosso país uma memória da história musical que privilegia a obra de um grupo de cantores/compositores preferido das elites, em detrimento da obra de artistas mais populares". ${ }^{215}$ Numa linha de argumentação que tem o caráter de polêmica aberta com a hegemonia da linhagem samba-bossa-MPB, Paulo Cesar de Araújo faz uma contundente crítica à seleção do repertório da música popular na pesquisa acadêmica, trazendo outros discursos musicais para a reflexão da história política e social. Esta discussão proposta por Araújo será abordada em outro momento no curso desta dissertação. Uma versão do

\footnotetext{
215 ARAÚJO, Paulo Cesar. Eu não sou cachorro, não: memória da canção popular "cafona" (1968-1978). Dissertação de mestrado em História. Rio de Janeiro: UNIRIO, 1999. Citações retiradas da publicação da dissertação: Eu não sou cachorro, não: música popular cafona e ditadura militar. 4⿳ạ ed. Rio de Janeiro: Editora Record, 2003, pp. 17-21.
} 
trabalho foi publicada no ano 2000 pela Editora Record e transformou-se num dos maiores sucessos editoriais da produção acadêmica do campo. ${ }^{216}$

A primeira pesquisa de pós-graduação realizada na área de História no Rio de Janeiro sobre música popular foi defendida na UFRJ em 1989, Uma estratégia de controle: a relação do poder do estado com as Escolas de Samba do Rio de Janeiro no período de 1930 a 1985, dissertação de mestrado de José Luiz de Oliveira. O objeto da pesquisa localiza-se "nas várias formas de intervenção direta ou indireta do Estado" nas escolas de samba cariocas, visando "demonstrar o caráter político-ideológico das relações mantidas entre o poder do Estado e as manifestações populares", com especial atenção para os desfiles que se realizaram durante o regime militar, período que o autor chama da "República Autoritária". Oliveira considera que "as relações entre o poder estatal no seu sentido mais amplo e as escolas de samba traduzem as pressões exercidas pelo Estado e as resistências dos setores populares num perfil que reflete, também, as mudanças políticas e ideológicas ocorridas na sociedade brasileira ao longo do período". Para o autor, ao longo de "uma mudança gradual da relação entre sambistas", a princípio perseguidos e marginalizados, e aparelho repressivo do Estado, as escolas internalizaram progressivamente uma "condição de colaboradoras voluntárias das elites dirigentes", que se materializava nos enredos "nacionais" e sem críticas à ordem política, social e econômica, num acordo tácito que envolvia as subvenções estatais. "A ascensão do desfile das escolas de samba ao lugar de principal manifestação carnavalesca fez-se acompanhar de todo um processo de elitização" do evento, cujo "caráter cada vez mais luxuoso e ostentatório" tornou elevadíssimos os custos financeiros, decorrendo daí uma aproximação progressiva entre "algumas das principais escolas e o mundo da contravenção". Com as transformações político-sociais ocorridas a partir de 1945 e especialmente após o golpe de 1964, desenvolveu-se paulatinamente a ambiguidade do sentido dos enredos dos desfiles. Como exemplos mais extremos, o autor aponta a postura "chapa branca" da Beija Flor de Nilópolis, de exaltação à ordem constituída nos carnavais de 1973, 1974 e 1975 e, por outro lado, os

\footnotetext{
216 Em 2006 Paulo Cesar Araújo publicou o livro Roberto Carlos em Detalhes pela Editora Planeta do Brasil, biografia não autorizada, que motivou uma batalha judicial com o cantor que resultou na proibição da distribuição da publicação, em episódio amplamente divulgado e discutido na impressa diária.
} 
enredos de contestação política da Caprichosos de Pilares nos anos 1980.217 O trabalho traz para a área de História uma questão que já havia sido abordada em pesquisas de outras áreas, especialmente Antropologia. ${ }^{218}$

\subsection{HISTORIOGRAFIA DOS MOVIMENTOS E GÊNEROS MUSICAIS}

Neste subitem, faremos um agrupamento das pesquisas que construíram seus objetos em torno de gêneros específicos de música popular, colocando o foco do estudo nas questões culturais e comportamentais de uma parcela da juventude ou da sociedade como um todo, e não nas conexões entre produção cultural e momento político. Algumas pesquisas se referem a certas vertentes musicais populares como "movimentos". A ideia de movimento não é muito precisa e não se encontra nenhuma definição para ela nessas pesquisas, mas em geral entende-se por movimento musical, artístico ou cultural uma certa corrente estética ou de pensamento que caracteriza um conjunto de autores, geralmente sem muita organicidade e com uma duração temporal delimitada. Por exemplo, são mencionados como movimentos musicais a bossa nova, a jovem guarda e a tropicália. Num período posterior, poder-se-ia incluir o rock nacional dos anos 1980 e o mangue beat, por exemplo.

Naturalmente estes agrupamentos dos trabalhos que estamos apresentando são esquemáticos e visam apenas facilitar um olhar panorâmico para a produção, uma vez que as questões estão entrelaçadas. Não estamos sugerindo que as pesquisas que listaremos a seguir tenham um olhar estanque e atomizado para apenas um dos aspectos sob os quais um gênero musical possa ser observado. Mas é interessante notar como os trabalhos que tomam por objeto a MPB ou o samba nos anos 1930 e 1940 têm uma tendência a estudar as conexões entre música e política. Já os que tomaram por objeto gêneros não tão claramente identificados com uma cultura política tendem a observar mais as questões culturais e comportamentais. Neste caso, temos estudos

\footnotetext{
217 OLIVEIRA, José Luiz de. Uma estratégia de controle: a relação do poder do estado com as Escolas de Samba do Rio de Janeiro no período de 1930 a 1985. Dissertação de mestrado. Rio de Janeiro: UFRJ, 1989, Resumo e pp. 120-123. 218 GOLDWASSER, Maria Julia. O Palácio do samba: estudo antropológico da Escola de Samba Estação Primeira de Mangueira. Dissertação de mestrado em Antropologia. Rio de Janeiro: UFRJ, 1975; LEOPOLDI, José Sávio. Escola de samba, ritual e sociedade, Dissertação de mestrado em Antropologia. Rio de Janeiro: UFRJ, 1975; RIBEIRO, Ana Maria Rodrigues. Samba negro, espoliação branca: um estudo das Escolas de Sambas do Rio de Janeiro. Dissertação de mestrado em Ciências Sociais. São Paulo: FFLCH-USP, 1981.
} 
sobre o momento do surgimento da bossa nova e as transformações na vida urbana carioca, a jovem guarda e o surgimento de um rock nacional, por exemplo. No estudo destes objetos tem destaque a questão do surgimento da juventude como ator social.

Bossa Nova é sal, é sol, é sul: música e experiências urbanas (Rio de Janeiro, 19541964), de Simone Luci Pereira, tem por objetivo analisar a bossa nova do ponto de vista da vida urbana e mostrar através da canção a dinâmica de uma cidade em mutação. Segundo a autora, o Rio de Janeiro transformava-se "tanto nas maneiras de se ver a cidade", como "na ocupação sistemática de novos espaços, como a praia, Copacabana e Ipanema, enfim, em novas formas de relação no âmbito público como no privado". Luci Pereira considera que a bossa nova "trazia em si pistas para se entender uma mudança comportamental em conformação com as mudanças do meio urbano" no qual se originou. Analisa "os projetos, símbolos e modelos comportamentais da bossa nova, no que eles dizem respeito à cidade na sua dinâmica histórica, em suas mudanças nas relações entre novo e arcaico, público e privado, feminino e masculino", bem como pretende olhar para a bossa nova "como um novo estilo de vida, para além de um novo estilo musical" na tentativa de trabalhá-la em seu aspecto comportamental. 219

Em sua dissertação de mestrado Jovens tardes de guitarras, sonhos e emoções: fragmentos do movimento musical-cultural Jovem Guarda, Ana Barbara Pederiva aborda um gênero até então pouco focalizado nas pesquisas e se propõe "questionar o conhecimento histórico sobre tal movimento, criando instrumentos para avaliação crítica, procurando rastrear as formas de viver e pensar desses jovens", "captando os sons e as experiências" de um "acontecimento de massa ou para a massa, de grande destaque na década de 1960". A partir de uma visão da jovem guarda como uma "manifestação específica do rock and roll no Brasil", a autora vai analisar a relação entre rock e juventude e refletir sobre os perfis de comportamento dessa parcela da juventude associada à jovem guarda, considerando as categorias juventude e gênero (enquanto expressão da sexualidade). Assim, procurara "desvendar como culturalmente as representações de juventude, no masculino e no feminino, foram construídas durante o movimento, detectando a constituição desses sujeitos históricos

219 PEREIRA, Simone Luci. Bossa Nova é sal, é sol, é sul: música e experiências urbanas (Rio de Janeiro, 1954-1964). Dissertação de mestrado em História. São Paulo: PUC/SP, 1998, p. 4 . 
sexuados" e o fluxo "das relações entre gerações e gêneros". ${ }^{220}$ Este é o único trabalho dentro do recorte desta pesquisa que aborda diretamente a questão do gênero associada à juventude, tema muito presente na agenda de estudos da música popular realizados no mundo anglo-americano. Esta aproximação faz sentido, na medida em que esta agenda está naturalmente muito pautada no rock, em suas várias vertentes e derivações, com as quais os movimentos de juventude estiveram intimamente associados desde sua explosão internacional no final dos anos $1950 .{ }^{221}$ Talvez em virtude do caráter pioneiro da pesquisa nas questões de juventude e gênero, e mesmo em relação ao rock no Brasil, a autora recorreu fartamente à bibliografia não acadêmica sobre o rock, tal como aconteceu em relação ao samba nas primeiras pesquisas da área de Letras na década de 1970. Entretanto, a autora poderia ter se utilizado do referencial teórico que vinha sendo desenvolvido em língua inglesa para a abordagem destas questões, bibliografia esta ausente na maioria dos trabalhos até o final da década de 1990.

Outra pesquisa que tem a jovem guarda por objeto é $A$ Jovem Guarda e os anos 60: uma festa de arromba ${ }^{222}$, dissertação de mestrado de Elizete Mello da Silva. ${ }^{223} \mathrm{Da}$ mesma forma, a autora considera que "o movimento jovem guarda surge na esteira da explosão do rock and roll internacional, no início da década de 1960", e procura contextualizar a poética musical do movimento no processo político e cultural vigente naquele momento histórico. Argumenta que, nessa época, a "indústria cultural" expandia-se plenamente no país, possibilitando o aparecimento de um movimento ligado à juventude. Demonstra que, entretanto, como fruto da postura tida como "alienada" dos seus integrantes, "a esquerda universitária procurou ignorar o movimento e classificá-lo como fruto da invasão cultural imperialista". Segundo a autora, "as leituras e interpretações das canções da jovem guarda tornam-se relevantes para detectar alguns signos importantes na compreensão do momento histórico", bem

\footnotetext{
220 PEDERIVA, Ana Barbara Aparecida. Jovens tardes de guitarras, sonhos e emoções: fragmentos do movimento musical Jovem Guarda. Dissertação de mestrado em História. São Paulo: PUC/SP, 1998, pp. 12-13.

${ }^{221} \mathrm{Em} 2004$ Pederiva defendeu tese de doutorado em Antropologia, na qual deu continuidade à sua pesquisa: Anos dourados ou rebeldes: juventude, territórios, movimentos e canções nos anos 60. São Paulo: PUC/SP.

222 SILVA, Elizete Mello da. A jovem guarda e os anos 60: uma festa de arromba. Dissertação de mestrado em História. Assis: FCL-UNESP, 1996, pp. 5 e 139-141

${ }^{223}$ Este trabalho tem como epígrafe uma frase de José Miguel Wisnik que também se encontra na abertura do livro de Vilarino, A MPB em movimento: 'Não é possível detectar aspectos de determinadas épocas no nível do seu 'sentir', senão pela arte e mais precisamente pela música. Não há vestígio histórico mais envolvente do que a música de determinados períodos..."
} 
como para entender as contribuições deixadas pelo movimento no panorama musical e cultural brasileiro. Para a autora, "toda atitude ou valores ligados com a satisfação das necessidades humanas podem corresponder às práticas culturais inseridas na sociedade, mesmo com objetivos de consumo". Elizete Silva deu continuidade à sua pesquisa no doutorado com a tese Indústria Cultural e Música Popular Brasileira nos anos 70,224 defendida em 2001, portanto fora do escopo deste estudo.

Banho de Lua: o rock nacional de Celly Campello a Caetano Veloso, de Christina Osward, tem o objetivo de analisar a inserção e a difusão do rock no Brasil. A autora apresenta um breve histórico do surgimento do rock and roll nos Estados Unidos e do rock inglês, numa narrativa muito centrada nos cânones do gênero, particularmente os Beatles e os Rolling Stones, e faz uma distinção entre as denominações, que ela chama de conceitos, de rock and roll, rock e o iê-iê-iê. Após uma breve narrativa sobre o surgimento da bossa nova, em função de sua coincidência histórica com o nascimento do rock and roll, a autora se ocupa da ascensão da jovem guarda e discute "os motivos pelos quais a classe média brasileira identificou-se com um tipo de música extremamente bem-comportada" em comparação com as matrizes internacionais do gênero. A autora considera Caetano e Gil como responsáveis pela introdução e disseminação de um novo tipo de rock no país. Osward destaca compositores e grupos que se dedicaram a fazer rock no início dos anos 1970, e aponta que, a partir do movimento tropicalista, "o rock adota um formato mais universalista e eventualmente transgressor". 225

Se este trabalho tangencia a questão do tropicalismo, outras duas pesquisas estariam diretamente focadas no tema. Tropicália ou Panis et Circencis no país do Rei da Vela, de Carmela Roseli Palmieri Parente Fialho, como o título sugere, estuda o tropicalismo como um movimento que englobou diversas linguagens artísticas, em suas manifestações no cinema, no teatro, nas artes plásticas e na música popular, que desempenha papel fundamental no movimento. A autora analisa como obras conceituais do tropicalismo nessas linguagens o filme Terra em Transe, de Glauber Rocha, a peça $O$ Rei da Vela, de Oswald de Andrade, encenada pelo grupo Oficina, a

\footnotetext{
224 SILVA, Elizete Mello da. Indústria Cultural e Música Popular Brasileira nos anos 70. Tese de doutorado em História. Assis: FCL-UNESP, 2001.

225 OSWARD, Christina. Banho de lua: o rock nacional de Celly Campello a Caetano Veloso. Dissertação de mestrado em História. Rio de Janeiro: PUC-Rio, 1998, Resumo e p. 2.
} 
obra-ambiental Tropicália, de Hélio Oiticica, além do LP Tropicália ou Panis et Circencis e os primeiros discos de Caetano Veloso e Gilberto Gil. A autora situa o tropicalismo no âmbito da constituição dos movimentos de juventude da década de 1960. Segundo Fialho, inspirados nas proposições antropofágicas de Oswald de Andrade, os tropicalistas "buscaram a elaboração de uma visão própria do que era o Brasil, captando o gosto das massas e transformando-o em um movimento capaz de encarnar o espírito da cultura criada nos trópicos". A autora aponta que, enquanto Oiticica e José Celso Martinez Corrêa "discordavam da entrada do tropicalismo na mídia, afirmando que esta banalizava e esvaziava o sentido revolucionário da antropofagia", os músicos trouxeram uma "interpretação mais abrangente", "devorando tudo, inclusive o consumo desenfreado" de sua produção através dos meios de comunicação. ${ }^{226}$

José Edson Schümann Lima em Brutalidade e jardim: as imagens da nação da tropicália, parte da visão da música popular no Brasil como "um dos principais elementos de construção da nacionalidade", emergindo, em função de sua popularidade, "enquanto campo privilegiado e lugar estratégico para a compreensão" da formação da identidade nacional no país. O estudo de Schümann Lima visa reconstituir as ideias e imagens de nação da tropicália a partir das discussões em torno da música popular na década de 1960, levando "em conta outras noções sobre o Brasil" em voga na época e também noções presentes "no plano mais longo da ideologia da cultura brasileira". Para situar as diversas visões sobre a tropicália, o autor faz uma revisão crítica da bibliografia, incluindo tanto ensaios contemporâneos aos eventos, entre os quais os de Mário Chamie, Roberto Schwarz, Tinhorão, Augusto de Campos, Júlio Medaglia e Gilberto Mendes, como textos do ensaísmo acadêmico que se desenvolveu a partir dos anos 1970, com destaque para os estudos de Gilberto Vasconcellos, Celso Favaretto, Heloisa Buarque de Hollanda e Santuza Cambraia Naves. Dos textos da década de 1960 Schümann Lima assume a proposição em voga na época, e bastante discutível, de que existia "uma crise na música popular no Brasil", crise esta que estaria entre as origens do tropicalismo. 0 autor vai localizar nos textos dos protagonistas do movimento tropicalista sua visão de nação, e compará-la com outras visões, particularmente aquelas presentes na canção de protesto e na ideologia do

226 FIALHO, Carmela Roseli Palmieri Parente. Tropicália ou Panis et Circencis: no país do Rei da Vela. Dissertação de mestrado em História. Rio de Janeiro: UFRJ, 1994, pp. 91-92. 
regime militar, assim como em visões do Brasil que influenciaram o tropicalismo, como as idéias de Oswald de Andrade e Gilberto Freyre. Segundo Lima, o tropicalismo dividiu “opiniões no campo da música expandindo a discussão para o campo da identidade nacional". Incorporando o "pensamento antropofágico de Oswald de Andrade", os tropicalistas enfatizavam "a mistura de culturas existente no país, partindo de uma ótica local para construir uma identidade nacional que fizesse frente a hegemonia cultural europeia e americana". Segundo o autor, a tropicália apontou para "uma ótica anti-dogmática, livre e construtiva", na qual "residiria a característica de uma identidade nacional, um estado de permanente crítica e construção cultural não redutível a nenhum sistema cultural, e ao mesmo tempo dentro e fora de todos eles". ${ }^{227}$

O protesto dos inconscientes: Raul Seixas e micropolítica, dissertação de mestrado de Juliana Abonizio, se propõe reconstituir "a trajetória de Raul Seixas visando compreender a construção do mito que se tornou, problematizando sua inserção no cenário musical, seu diálogo com outros movimentos artísticos e as temáticas" de suas canções ao longo das décadas de 1970 e 1980. Analisa também a formação de um "raulseixismo", que sobreviveu à sua morte, procurando entender "os fundamentos de sua filosofia e a apropriação do seu discurso por seus fãs" e seguidores. A autora analisa "a proposta raulseixista enquanto uma recusa à sociedade estabelecida, criando uma utopia nascida em um determinado contexto e estendendose a ele", como ela localiza no comportamento de seus fãs. Segundo Abonizio, embora Raul Seixas seja um artista surgido dentro da mídia, "ele transmite uma ideologia que contraria o sistema defendido pela própria mídia", que vincularia uma subjetividade que ela classifica como "capitalística". Para a autora, "diferentemente da rebeldia dos movimentos estudantis da geração anterior que preconizavam a revolução comunista, o raulseixismo e seus partidários aproximava-se mais da visão contracultural que desejava subverter as lógicas racionalizantes de direita e de esquerda". Os raulseixistas formariam um grupo pequeno que engendraria outras subjetividades, num processo "micropolítico", sem referir-se à totalidade e às mudanças estruturais. ${ }^{228} 0$ trabalho, que poderia também estar relacionado no item seguinte, dedicado às trajetórias

227 LIMA, José Edson Schümann. Brutalidade e jardim: as imagens da nação da tropicália. Dissertação de mestrado em História. UFRJ, 1998, pp. 2-3 e 146-147.

228 ABINIZIO, Juliana. O protesto dos inconscientes: Raul Seixas e micropolítica. Dissertação de mestrado em História. Assis: FCL-UNESP, 1999, pp. 8, 15 e 433-435. 
individuais, tem um tom de enaltecimento do personagem retratado. A autora seguiu estudando o tema na tese de doutorado em Sociologia, A chave da Sociedade Alternativa. ${ }^{229}$

A temática da música rural é retomada por Wolney Honório Filho, que discute as representações do sertão apresentadas pela música rural em sua dissertação de mestrado O Sertão no embalos da música rural (1929-1950). 0 autor considera que a "discussão sobre a modernidade na historiografia brasileira" tende a se orientar essencialmente "por problemas circunscritos ao espaço urbano" ou ao "processo de migração campo-cidade". Argumenta que seu texto tenta percorrer o caminho inverso, interessando-se pelo que "determinados grupos citadinos, que passaram pela experiência de vida no campo e na cidade", pensaram e cantaram sobre o sertão. Sua análise está centrada na "visão que se faz do campo". Procura desvendar quais "significações rurais estavam em jogo quando da inauguração dos discos caipiras e que imagens rurais passam a predominar no seu interior". Assim, o objetivo é "analisar as transformações na música sertaneja durante o período que vai do lançamento do gênero sertanejo em disco em 1929, até o final dos anos 1950", procurando ressaltar, sobretudo, "as representações que emergiram sobre o campo, quando são os parâmetros da modernidade, voltando seu olhar para a cidade, que passam a predominar". Segundo o autor, "a prática da gravação em disco do conteúdo musical rural interfere na tradição de música do campo, fazendo ver novos modelos sonoros, assim como novas visões sobre o sertão". ${ }^{230}$

Existe um outro trabalho sobre a música caipira presente na Grande São Paulo a partir dos anos 1960, Ponteio na cidade: música caipira e identidade social, ${ }^{231}$ de autoria de Nelson Martins Sanches Júnior, que infelizmente encontra-se extraviado, segundo informação da biblioteca da Faculdade de Ciências e Letras da UNESP, campus de Assis, não existindo nenhuma cópia disponível em outra biblioteca. No período, ainda sobre a questão da música sertaneja, mas fora do recorte desta pesquisa, existe a tese de PhD desenvolvida na área de musicologia na Cornell University, Estados Unidos,

229 ABONIZIO, Juliana. A chave da Sociedade Alternativa. Tese de doutorado em Sociologia. Araraquara: FCL-UNESP, 2005.

230 HONÓRIO FILHO. Wolney. O sertão nos embalos da música rural (1929-1950). Dissertação de mestrado em História. São Paulo: PUC/SP, 1992, pp. 7-8 e 29-30.

231 SANCHES JUNIOR, Nelson Martins. Ponteio da cidade: música caipira e identidade social. Dissertação de mestrado em História. Assis: FCL-UNESP, 1997. 
de autoria de Martha Tupinambá de Ulhôa, Música popular in Montes Claros, Minas Gerais, Brazil: a study of middle-class popular music aesthetics in the 1980 s. $^{232}$ Neste trabalho, a autora olha para um período mais recente com uma visão mais favorável do gênero do que aquela apresentada por Waldenyr Caldas nos anos 1970. Uma outra pesquisa, orientada por Waldenyr Caldas na área de Comunicação, “...isto é 'brega'”: Isto é brega,233 de autoria de Carmen Lucia José, tinha por projeto original revisar as proposições defendidas em Acorde na Aurora. Entretanto a autora constatou, no curso da pesquisa, que o gênero sertanejo já dividia espaço com outra modalidade musical, denominada de "brega", razão pela qual o projeto ficou reorientado para a discussão do fenômeno dito "brega".

\subsection{HISTORIOGRAFIA E TRAJETÓRIAS INDIVIDUAIS}

Algumas pesquisas têm seu objeto construído em torno da obra de compositores ou intérpretes, adquirindo, assim, um certo aspecto biográfico. De um modo geral, estes trabalhos de corte biográfico procuram articular em torno da vida de personagens marcantes da música popular leituras histórico-sociológicas do período de sua atuação ou questões culturais e comportamentais a ela relacionadas. No período que vai de 1971 a 1999, além do trabalho sobre Raul Seixas mencionado no item anterior, foram foco de pesquisas de pós-graduação na área de História em São Paulo e no Rio de Janeiro, Luiz Gonzaga, Chico Buarque, Custódio Mesquita e Chiquinha Gonzaga, com dois trabalhos.

Na tese de doutorado Luiz Gonzaga: o migrante nordestino na música popular brasileira $^{234}$ Antonio Gomes da Silva procura explicar como Luiz Gonzaga, com a colaboração de Humberto Teixeira, conseguiu, por volta da metade da década de 1940, fazer com que o baião ocupasse espaço junto ao mercado musical da época. 0 autor considera que Luiz Gonzaga constituiu-se "no primeiro 'fenômeno' de música relacionado diretamente à indústria fonográfica no Brasil” e procura explicar como isso

\footnotetext{
232 ULHÔA, Martha Tupinambá de. Música popular in Montes Claros, Minas Gerais, Brazil: a study of middle-class popular music aesthetics in the 1980s. Tese de PhD Musicologia. Cornell University, C.U., Estados Unidos, 1991.

233 JOSÉ, Carmen Lucia. “...isto é 'brega"': Isto é brega. Dissertação de mestrado em Comunicação. São Paulo: ECA-USP, 1991.

234 SILVA, Antonio Gomes da. Luiz Gonzaga: o migrante nordestino na música popular brasileira. Tese de doutorado em História. São Paulo: FFLCH-USP, 1986.
} 
teria ocorrido. Discute também como na metade da década de 1950 ele já não ocupava mais o mesmo espaço, ausentando-se do cenário nacional, e como se deu sua volta aos grandes palcos, ao rádio e à mídia em geral na década de 1970. 0 trabalho segue como metodologia a história de vida e tem o materialismo histórico como visão da história e uma concepção da sociedade e da arte apoiada numa leitura stalinista do marxismo. Considerando a música como um reflexo da sociedade, o autor trabalha com uma ideia de "povo" ou "massas populares" como as classes e grupos sociais que, num dado contexto histórico, resolvem as tarefas de desenvolvimento progressista da sociedade. O trabalho apresenta um tom apologético sobre Luiz Gonzaga e o autor desenvolve um raciocínio no sentido de colocá-lo como representante das classes populares.

Orlando de Barros em Custódio Mesquita, um compositor romântico: o entretenimento, a canção sentimental e a política no tempo de Vargas (1930-1945), toma como personagem central o compositor popular e artista atuante em distintas atividades, especialmente no rádio e no teatro, Custódio Mesquita, cuja carreira artística apresenta uma completa coincidência cronológica com o primeiro governo de Getúlio Vargas. Este trabalho, embora articulado em torno da figura de Custódio Mesquita, é também um estudo de história política e discute o contexto sociocultural da época. Muito reconhecido em seu tempo, quando era tão popular quanto Noel Rosa e Ari Barroso, o nome de Custódio não ocupa lugar destacado na historiografia da música popular, sendo este esmaecimento de sua memória uma das questões que o autor se propõe a enfrentar. Através da análise da trajetória de Custódio Mesquita, Orlando de Barros faz um estudo de diversos aspectos da cultura massiva durante a Era Vargas, abordando o estabelecimento do entretenimento público no Brasil e enfatizando particularmente a canção popular urbana. "Época de mudanças, de desenvolvimento industrial e crescimento urbano", o período caracteriza-se, segundo o ator, "também por um notável incremento dos meios de comunicação social" - cinema, teatro, imprensa e, especialmente, o rádio. Barros destaca a utilização por parte do governo Vargas desses meios "para promover a integração de um país ainda formado por regiões mal integradas", observando também como estes meios se aproveitaram das circunstâncias e "desenvolveram-se a partir de um sistema de entretenimento que havia florescido sobretudo no Rio de Janeiro", estabelecendo "fortes laços com o 
sistema econômico em geral, espelhando aspectos importantes do capitalismo emergente". O autor demonstra como o rádio reuniu "experiências do teatro, da literatura popular, do registro fonográfico, do jornal ou revista, e principalmente, da canção" popular, criando uma "base de entretenimento popular capaz de prender a atenção do ouvinte", condição necessária para a locução publicitária e para sua utilização política através da "presença do governo nos programas obrigatórios". Ao longo do texto, o autor vai dissertar sobre diversos aspectos do meio artístico e da vida cultural da época, alinhavados em torno da figura de Custódio Mesquita, com destaque para a canção popular. ${ }^{235}$

Dimensões da vida urbana sob o olhar de Chico Buarque, de Míriam Porto Noronha, tem como objetivo explorar as experiências sociais urbana e seus significados, utilizando-se das canções de Chico Buarque de Hollanda, numa análise focada no discurso literário. A autora entende que nessas canções se encontram "construções de dimensões da realidade", o que possibilita sua utilização como documento histórico. Ao longo do trabalho a autora procurou "recuperar os cenários em que as personagens criadas por Chico vivenciaram suas experiências", identificar "quais as personagens marcantes em sua obra musical, qual o significado do feminino em suas canções e as possíveis razões da forte identificação do público com a música de Chico Buarque". 236

Chiquinha Gonzaga foi objeto de duas dissertações de mestrado no período, ambas realizadas no Rio de Janeiro, contrastando com sua presença por vezes minimizada em algumas narrativas da história da música no Brasil. A primeira delas, Chiquinha Gonzaga no Rio de Janeiro da "Belle Époque": um ensaio de memória, de Cleusa de Souza Millan, traça a trajetória da compositora, desde o Segundo Reinado até as três primeiras décadas da República, com ênfase no Rio de Janeiro da 'Belle Époque'”. A autora situa sua importância na história da música popular do país, "por representar a fase de transição, em que se iniciou a fixação de uma temática brasileira na nossa música em meio ao predomínio de uma cultura 'europeizante'”. Considera

235 BARROS, Orlando de. Custódio Mesquita, um compositor romântico: o entretenimento, a canção sentimental e a política no tempo de Vargas (1930-1945). Tese de doutorado em História. São Paulo: FFLCH-USP, 1995, pp. 317318.

236 NORONHA, Miriam Porto. Dimensões da vida urbana sob o olhar de Chico Buarque. Dissertação de mestrado em História. São Paulo: PUC-SP, 1994, p.: Resumo. 
que, "apesar da ressonância de sua obra", a memória social da compositora situa-se "num aparente dualismo": conhecida pela elite cultural, é desconhecida do povo. A partir de uma percepção intuitiva desta dicotomia, a autora se propõe equacionar e analisar as causas deste desconhecimento e consequente esquecimento por parte do "povo brasileiro". Millan formula um conjunto de hipóteses e conclui que nenhuma delas, isoladamente pode explicar esse fato. Como conclusão, afirmando a necessidade de "situar adequadamente sua memória da compositora na memória coletiva do povo brasileiro", apresenta um conjunto de possíveis iniciativas nesse sentido. ${ }^{237}$

A dama da boêmia: imagens de Chiquinha Gonzaga, de Lícia Gomes Mascarenhas, Universidade Federal Fluminense, 1998, “aborda as diversas imagens da compositora Chiquinha Gonzaga construídas em dois momentos: ao longo de sua carreira e após a sua morte". Através da análise de artigos de jornal, publicados nos dois períodos, e três biografias da musicista, a autora observa "dois eixos principais em torno dos quais estas imagens foram produzidas: a transgressão dos limites impostos à condição feminina e a criação de uma música tipicamente brasileira". ${ }^{238}$

Um outro exemplo de pesquisa articulada em torno de trajetória individual é $O$ "it" verde e amarelo de Carmen Miranda (1930-1946), tese de Tânia da Costa Garcia, fora da periodização deste estudo. Nesse trabalho a autora analisa a trajetória artística da cantora e atriz Carmen Miranda, situando "a intérprete da canção popular na discussão que se estabelecia na década de 1930 sobre música e identidade nacional". Procura ainda "desvendar de que maneira a baiana estilizada criada por Carmen dentro da atmosfera nacionalista desse período, ao imigrar para os Estados Unidos, tornou-se em Hollywood um símbolo da identidade nacional e latino-americana". 239

A tese de livre docência de Alcir Lenharo, No fim da estrada: a trajetória artística de Nora Ney e Jorge Goulart no tempo dos cantores do rádio ${ }^{240}$, poderia ser incluído neste subitem dedicado à historiografia organizada em torno de estudos

\footnotetext{
237 MILlAN, Cleusa de Souza. Chiquinha Gonzaga no Rio de Janeiro da "Belle Époque": um ensaio da memória. Dissertação de mestrado em Memória Social e Documento. Rio de Janeiro: UNIRIO, 1996, p. 6.

238 MASCARENHAS, Lícia Gomes. A dama da boêmia: imagens de Chiquinha Gonzaga. Dissertação de mestrado. Niterói: UFF, 1999, p.: Resumo.

239 GARCIA, Tânia da Costa. O "it" verde amarelo de Carmem Miranda. Tese de doutorado em História. São Paulo: FFLCH-USP, 2000. Publicada com título homônimo pela Annablume/FAPESP, 2004, p. 13.

240 LENHARO, Alcir. No fim da estrada: a trajetória artística de Nora Ney e Jorge Goulart no tempo dos cantores do rádio. Tese de livre docência. UNICAMP, 1992. Publicada como Cantores do rádio: a trajetória de Nora Ney e Jorge Goulart e o meio artístico do seu tempo. Campinas: Editora da UNICAMP, 1995.
} 
biográficos, na medida em que, através da trajetória de Jorge Goulart e Nora Ney, Lenharo estuda a música e o contexto cultural dos anos 1950, o rádio, seus artistas e as transformações nos circuitos de produção e consumo que levaram ao esquecimento dos cantores do rádio. Mas vamos incluí-lo no subitem seguinte para colocá-lo junto a outros trabalhos dedicados à chamada Era do Rádio.

\subsection{HISTÓRIA, MÚSICA E CIRCUITOS DE PRODUÇÃO E CONSUMO}

Lenharo discute a questão da "produção social da memória" através da biografia de Nora Ney e Jorge Goulart, personagens que ele considerou emblemáticos do esquecimento geral destinado aos artistas que foram sucesso de público nos anos 50. Na sua visão, os estudos da música popular estavam seguindo uma tendência similar à do público em geral, de desconsiderar a produção dos chamados "Anos Dourados". O autor aponta a biografia de Noel Rosa, escrita por Carlos Didier e João Máximo 241 , como texto que valoriza a produção musical dos anos 1930, e o livro de Ruy Castro sobre a bossa nova ${ }^{242}$ como exemplo de uma posição que coloca o gênero como marco de um salto qualitativo no campo da música popular. E se pergunta "o que sobrou para o período intermediário", do qual pouco se fala e em geral se ressalta apenas "a euforia das 'macacas de auditório' e os escândalos" e rivalidades entre os cantores, não se atribuindo "importância musical a essa época". 0 autor se propôs olhar para o período em sua singularidade, questionando as narrativas tradicionais através da pesquisa em vasto corpo documental cruzada com depoimentos dos biografados e outros.

0 texto de Lenharo insere-se na perspectiva de uma História Cultural da música popular. $\mathrm{O}$ autor afirma claramente ter a intenção de fazer do seu texto "um recurso metodológico" através do qual procura "inovar em termos de recuperação do passado e de construção do conhecimento histórico". Em suas palavras, não foi "a grande política, nem os grandes acontecimentos" que o atraíram "para a captura do espírito do tempo e o desvendamento cultural de uma época", mas os cantores do rádio, "personagens incrivelmente afinados com seu tempo, com sua cultura, com suas

241 DIDIER, Carlos; MÁXIMO, João. Noel Rosa: uma biografia. Linhas Gráficas Editora/ Editora da UNB, 1990. 
transformações, com seus sonhos e realizações". Seu trabalho tronou-se uma referência fundamental nos estudos sobre rádio e sobre um tempo em geral um tanto renegado pela historiografia e pelos estudos da música popular no Brasil de um modo geral. ${ }^{243}$

Alcir Lenharo foi o orientador da dissertação de mestrado de Maria Marta Picarelli Avancini, Nas Tramas da Fama: as estrelas do rádio em sua época áurea, Brasil anos 40 e 50.244 Esta pesquisa acompanha o surgimento das estrelas do rádio a partir do final da década de 1940. Considera que "os artistas ligados ao rádio são elevados à condição de estrelas por meio de mecanismos característicos da cultura e da comunicação de massa", num processo que marca "a consolidação e a intensificação" de seus "procedimentos e modos de funcionamento" no Brasil. Avancini discute dois tipos de abordagens que considera clássicas no debate sobre a radiofonia brasileira. De um lado, “a priorização da dependência do rádio às estruturas do poder econômico e político", com consequente ênfase no sentido de dominação; de outro, "a possibilidade do rádio funcionar como autêntico canal de expressão popular, embora a determinação econômica não seja completamente descartada". A autora cita como emblemáticos destas posturas os trabalhos de Maria Elvira Federico e José Ramos Tinhorão, ${ }^{245}$ que retraduziriam "abordagens consagradas da cultura de massas, compreendendo-a, respectivamente, pela esfera da produção e do consumo". Dialoga com as elaborações de Adorno, Eco e Morin, e também com o trabalho clássico de Miriam Goldfeder, ${ }^{246}$ para quem a dominação não se daria "de forma unívoca, mas num movimento que qualifica como pendular: ora a cultura de massa funciona rigorosamente dentro do projeto de dominação que a orienta, ora responde às necessidades mais genuínas do público". Rejeitando análises que considera generalizantes, Avancini procura identificar a singularidade dos processos de constituição e funcionamento do circuito cultural, de práticas, sociabilidades e estéticas potencializadas em torno das estrelas do rádio nos anos 1940 e 1950. Procura demonstrar como, por meio de mecanismos de exposição

\footnotetext{
243 LENHARO, Alcir. Cantores do rádio. Campinas: Editora da UNICAMP, 1995. pp. 8-11.

244 AVANCINI, Maria Marta Picarelli. Nas tramas da fama: as estrelas do rádio em sua época áurea, Brasil, anos 40 e 50. Dissertação de mestrado em História. Campinas: IFCH/UNICAMP, 1996, pp. 6, 14 e 35.

245 FEDERICO, Maria Elvira Bonavita. História da Comunicação: rádio e TV no Brasil. Petrópolis: Vozes, 1982; TINHORÃO, José Ramos, Música popular: do gramofone ao rádio e TV. São Paulo, Ática, 1981. Apud AVANCINI, op.cit., p.2-7.

246 GOLDFEDER, Miriam. Por trás das ondas da Rádio Nacional. Rio de Janeiro, Paz e Terra, 1980. Publicação da dissertação de mestrado em Ciência Política Manipulação e participação: a Rádio Nacional em debate. Campinas: IFCH/UNICAMP, 1977.
} 
dos artistas e, em especial, cantoras, criam-se determinadas figuras cujos perfis combinam elementos ligados à vida privada delas, às músicas que cantam e a fatos que acontecem com elas. Segundo a autora, num processo "em que se cruzaram séries discursivas e sígnicas diversas, criam-se territórios que definem modos de ser, comportamentos e sociabilidade que demarcam a chamada cultura do rádio" nos anos 1940 e 1950, delineando-se "uma estética historicamente demarcada".

Quando canta o Brasil: a Rádio Nacional e a construção de uma identidade popular 1936-1945, de Claudia Maria Silva de Oliveira, aborda o período anterior ao da dissertação de Avancini. Tem a proposta de pesquisar a construção de um modelo de radiodifusão e de uma linguagem radiofônica variada e eclética no período, a partir das atuações dos artistas da Rádio Nacional. Para demonstrar o que considera criações individuais "improvisacionais" de uma "nova linguagem radiofônica", a autora analisou quatro modalidades artísticas da Rádio Nacional, através das figuras de Orlando Silva, Radamés Gnattali, Almirante e da dupla Jararaca e Ratinho. Discute também os dois modelos de radiofonia que se delinearam nos anos 1930, que denomina de "modelo erudito-educativo, difundido pela Rádio do Ministério da Educação" e "modelo popularcomercial”. A autora toma Mikhail Bakhtin como referencial para a reconstrução do perfil do artista popular, situando-o como personagem do universo cômico, e Roberto da Matta, para a reconstrução do universo do cantor e do profissional de rádio em geral. Oliveira cita também o trabalho de Miriam Goldfeder e textos de Sérgio Cabral e Ruy Castro, entre outras biografias. Compara o que considera a "linguagem inovadora da Rádio Nacional" e a "linguagem conservadora da radiodifusão oficial" e conclui que a nova linguagem emergiu, cresceu e se impôs "porque era a síntese de todas as vozes que compunham o universo social do Brasil". Para a autora, "a Rádio Nacional foi o espaço de criação das várias heterogeneidades que compunham a cultura brasileira e também o espaço para difusão nacional desta cultura". 247

A dissertação de mestrado de Raimundo Dalvo da Costa Silva, Cotidiano, memórias e tensões: a trajetória artística das cantoras do rádio de Salvador de 1950 a 1964, tem por objetivo "recuperar a história das cantoras do rádio de Salvador", "mostrando sua trajetória artística e cultural" na cidade. "Procura compreender sua

247 OLIVEIRA, Cláudia Maria Silva de. Quando canta o Brasil: a Rádio Nacional e a construção de uma identidade popular (1936-1945). Dissertação de mestrado em História. Rio de Janeiro: PUC-Rio, 1996, pp. Resumo, 6-7, 44 
história de vida até se formarem como cantoras do rádio e como vivenciaram e apropriaram-se dos ambientes artísticos" de Salvador. A pesquisa foi construída "a partir, basicamente, das memórias das cantoras e de outras pessoas que vivenciaram a cidade e os tempos áureos do rádio", procurando mostrar "as experiências vividas pelas cantoras como também o cenário social de Salvador", dos anos 1950, "quando o rádio atingiu o seu ápice, e conclui na década de 1960, momento em que o rádio passou por um processo de mudança e extinção dos seus programas de auditório em razão do golpe militar de 1964." Trata-se de um trabalho de memória social, na linha da história oral, no qual a questão musical propriamente dita não está no primeiro plano. ${ }^{248}$

Sobre a vida musical de Salvador, no mesmo momento histórico, mas com o foco numa prática instrumental, existe a dissertação de mestrado Violão, violonistas $e$ memória social nas décadas de 50 e 60 em Salvador, do excelente guitarrista e violonista Carlos Edmundo Chenaud Drehmer (Carlito), estudo sobre "a memória do violão, as tradições musicais e a experiência dos violonistas em Salvador, nas décadas de 1950 e 1960". Com base em depoimentos orais de violonistas que atuaram naquele período e em pesquisas na imprensa de época, o autor reflete sobre "a memória social, a cultura violonística e a experiência social desses personagens que viviam e atuavam em Salvador, acentuando um recorte dos territórios, em um trajeto intermediado entre a cidade, os músicos, o trabalho, e os meios de difusão". Músico de formação e atuação profissional, professor da Universidade Católica de Salvador, Carlos Drehmer estuda, sem valorações ou hierarquias, as práticas violonísticas das tradições musicais que denomina de "formal-erudita" e de "informal-popular". Formal e informal dizem respeito aos modos de aprender e tocar, e o autor aponta conexões e circularidades entre estas práticas. Uma referência importante para o trabalho foi Cantores do Rádio, de Alcir Lenharo, enquanto forma de se olhar a história social da cultura e a questão da memória e do esquecimento. Esquecimento que, para o autor, "é maior no caso dos músicos instrumentistas, violonistas, que não tiveram o papel de destaque dos cantores e/ou solistas". Drehmer aponta que a historiografia da música raramente se refere à instrumentistas acompanhantes ou mesmo solistas "que ficaram distantes do eixos nacionais de difusão. 0 autor mostra que na "prática de esquecimento em relação à

248 SILVA, Raimundo Dalvo da Costa. Cotidiano, memória e tensões: a trajetória artística das cantoras do rádio de Salvador de 1950 a 1964. Dissertação de mestrado em História. PUC-SP, 1999, pp. 7, 16 e 110. 
musica instrumental", especialmente àquela da tradição informal-popular, muito elementos se perderam "tais como técnicas, arranjos e composições" daqueles que não tiveram oportunidade de gravar suas performances. Entretanto, acredita que parte dessas tradições sobreviva incorporada nas formas de tocar dos violonistas que os sucederam. 0 trabalho coloca ênfase nas práticas musicais, nos modos de aprender e tocar o instrumento, de sobreviver como músico e de atuação num momento em que estas práticas estavam em transformação. ${ }^{249}$

\subsection{HISTORIOGRAFIA, LINGUAGEM E TEMAS POÉTICOS.}

No ar: amores amáveis. Um estudo sobre a produção do amor na música brasileira (1951-1958), tese de doutorado de Wolney Honório Filho, analisa "movimentos de promoção do amor, como um modo específico e singular de sentir emoção, no interior dos circuitos culturais da época, privilegiando os periódicos especializados sobre o mundo da música". O autor aponta que "o conteúdo amoroso não era uma novidade temática nas letras dos anos 1950" e nem mesmo o era em períodos anteriores, “como no tempo de Noel Rosa". Porém, investiga a hipótese de que, "para o final dos anos 1940 até a segunda metade dos anos 1950, é a presença do rádio, bem como de indústrias de discos e de um mercado editorial com publicações de letras de lançamentos musicais, histórias de vida de cantores, locutores de rádio e outras personalidades do mundo artístico, fomentam novas configurações amorosas na sociedade brasileira". Na pesquisa, tem destaque os "relatos amorosos imersos tanto nas canções interpretadas principalmente por Ângela Maria, gravadas em disco de 78 rpm, quanto nas formas de constituição da cantora como intérprete de sucesso no cenário musical do Brasil dos anos 1950". 250

Trilha sonora: topografia semiótica paulistana nas canções independentes das décadas de setenta e oitenta, de Fátima Amaral Dias de Oliveira, trabalho que teve a orientação de Alcir Lenharo, pretende discorrer "sobre as percepções do cotidiano na cidade de São Paulo" por "uma aproximação musical”. o trabalho oscila entre um

\footnotetext{
249 DREHMER, Carlos Edmundo Chenaud. Violão, violonistas e memória social nas décadas de 50 e 60 em Salvador. Dissertação de mestrado em História. PUC-SP, 1999, pp. 14-16 e 19-20.

${ }^{250}$ HONÓRIO FILHO, Wolney. No ar: amores amáveis. Um estudo sobre a produção do amor na música brasileira 1951-1958. Tese de doutorado em História. PUC/SP, 1998, pp. 7 e 24.
} 
aspecto cultural da cidade de São Paulo, com sua "trilha sonora", suas sonoridades características, as canções independentes do grupo de músicos que se convencionou chamar de Vanguarda Paulista e a produção musical não plenamente absorvida pelo mercado de um modo mais geral. ${ }^{251}$

\subsection{A PESQUISA ACADÊMICA E SEUS DOMÍNIOS HISTORIOGRÁFICOS}

Está além dos objetivos deste trabalho mapear as linhas de pesquisas da História, não claramente demarcadas e objeto de diferentes interpretações mesmo para especialistas no assunto. Podemos pensar, de um modo genérico, dentro do universo de pesquisas do nosso tema, as seguintes linhas principais: História Social, História Cultural e História Política. Estas linhas de pesquisas estão presentes, por vezes com outras denominações, nos programas de pós-graduação em História nos locais onde encontramos pesquisas sobre música popular. A estas linhas, podemos acrescentar, no caso do nosso objeto, trabalhos de corte biográfico que articulam estudos sobre a vida e a obra de determinados personagens com análises dos eventos sócio-político-culturais contemporâneos. Estas linhas de pesquisa são por vezes englobadas na denominação genérica de "história social".

A expressão "história social" comporta múltiplas interpretações. Num sentido amplo, a expressão é frequentemente utilizada para designar uma postura historiográfica que se constituiu em contraposição à historiografia política tradicional, centrada nos acontecimentos e na atuação dos grandes homens, que teve um marco no movimento dos Annales. Conforme Hebe Castro, "a revista e o movimento fundados por Bloch e Febvre, na França, em 1929, tornaram-se a manifestação mais efetiva e duradoura" contra a historiografia política tradicional. "Propunham uma históriaproblema" e a "abertura da disciplina às temáticas e métodos das demais ciências humanas, num constante processo de alargamento de objetos e aperfeiçoamento metodológico. A interdisciplinaridade serviria como base para a formulação de novos problemas, métodos e abordagens da pesquisa histórica, que estaria inscrita na vaguidão oportuna da palavra 'social'”. A fixação da expressão neste sentido amplo

251 OLIVEIRA. Fátima Amaral Dias de. Trilha sonora: topografia semiótica das canções independentes das décadas de setenta e oitenta. Dissertação de mestrado em História. Campinas: IFCH-UNICAMP, 1990, p. 3. 
teria também a função de reafirmação do princípio de que, em história, "todos os níveis de abordagem estão inscritos no social e se interligam". ${ }^{252}$

Ainda que, com o quase desaparecimento das abordagens tradicionais e a ocupação do campo historiográfico pelas novas posturas, esta concepção ampla de história social tenha perdido em grande parte sua razão de ser, ela ainda é frequentemente empregada como forma de demarcação do espaço frente às abordagens da história política tradicional. Esta utilização, por exemplo, encontra-se na apresentação do programa de pós-graduação em História Social da Universidade de São Paulo:

O programa continua expressando, na sua denominação, a filiação à "História Social" porque é ela que articula as várias particularidades internas do Programa, é ela que lhe confere identidade e é por meio dela que se expressam as preocupações com a compreensão dos fenômenos históricos. Assim sendo, entendemos que mesmo quando nos debruçamos prioritariamente sobre aspectos políticos, institucionais ou culturais do processo histórico, o fundo comum de nossas preocupações é sempre a história social - seja a de caráter mais sociológico; seja a história social renovada, nos moldes da historiografia inglesa da segunda metade do século $\mathrm{XX}$. Sob essa ótica, articulam-se nossas diferentes linhas de pesquisa, no interior das quais os pesquisadores podem, então, dedicar-se às especificidades e especialidades. ${ }^{253}$

Nesta concepção ampla de história social, toda a historiografia da música popular realizada nos programas de pós-graduação em História, e mesmo em outras áreas, pode ser entendida como história social da música. Arnaldo Contier, na introdução de Brasil Novo: música, nação e modernidade apresenta alguns parâmetros para uma história social da música, entendida nesta acepção genérica:

A História Social da Música visa a questionar possíveis elos que se poderia estabelecer entre a música e as estruturas econômicas, políticas e culturais de uma formação social, num momento histórico cronologicamente determinado. Tais estudos históricos devem privilegiar as conexões entre a produção artística e a sua decodificação por um público específico. Além disso, devem discutir os possíveis obstáculos para a concretização de um determinado projeto estético (...). Em síntese, a História Social da Música deve ter em mira

\footnotetext{
252 CASTRO, Hebe. História Social. In: CARDOSO; VAINFAS (orgs.).Domínios da História: ensaios de teoria e metodologia. Rio de Janeiro: Campus, 1997, pp. 76-77.

253 FFLCH-USP. Programa de Pós-Graduação em História Social. Apresentação do programa. Disponível em: $<$ www.fflch.usp.br/dh/pos/hs/index.php?option=com_content\&view=article\&id=1\&Itemid=18>. Acesso em: 11 out. 2010. O Departamento de História da USP tem dois programas de pós-graduação: História Econômica e História Social. Também a Universidade Federal do Rio de Janeiro tem dois programas, sendo um deles com a denominação de História Social como área de concentração (o outro é História Comparada) e estrutura-se em três linhas de pesquisa: sociedade e cultura, sociedade e política e sociedade e economia.
} 
não somente o estudo da criação artística em relação à sociedade, mas, também da vida de um grupo social e da relação deste com a arte.254

Mas existe também uma acepção mais restrita para história social, enquanto um campo ou área temática específica da disciplina histórica, surgida como abordagem que buscava formular problemas históricos específicos quanto ao comportamento e às relações entre os diversos grupos sociais. ${ }^{255}$ Em Domínios da História, obra coletiva organizada por Ciro Flamarion Cardoso e Ronaldo Vainfas, o campo historiográfico é apresentados na Parte 1 (Territórios do Historiador: Áreas, Fronteiras, Dilemas) em 5 capítulos assim distribuídos: 1. História Econômica; 2. História Social; 4. História e Poder; 4. História das Ideias; 5. História das Mentalidades e História Cultural.256 Analisando a historiografia brasileira recente, desde uma perspectiva crítica que visava observar o lugar da história das idéias nesta historiografia, Francisco Falcom observou que as "áreas temáticas" são geralmente definidas "em termos de história econômica, política, social, regional e cultural”. ${ }^{257}$ Com algumas variações e especificidades, são estas linhas que podemos encontrar nos programas de pós-graduação em História. Naturalmente, a produção desenvolvida sob estas "etiquetas" não tem necessariamente um caráter harmônico e homogêneo do ponto de vista teóricometodológico, uma vez que em geral são articuladas diversas tendências e referências, incluindo instrumentais teóricos de outras áreas, como a Sociologia, a Antropologia, a Linguística, a Semiótica e, mais raramente, a Musicologia. Além disso, em alguns trabalhos é possível encontrar um certo ecletismo teórico, do ponto de vista da filiação às correntes historiográficas mais delineadas. Um enfoque possível é observar a música da perspectiva de uma história da cultura brasileira. Teríamos então uma abordagem dentro da linha denominada História Cultural, que vem ocupando internacionalmente espaço relevante na historiografia a partir de inúmeros trabalhos seminais realizados a partir da década de 1970. Ou, numa abordagem mais híbrida, entendendo a história da cultura como uma linha da história social no seu sentido restrito, teríamos uma história social da cultura. Por outro lado, a música popular urbana no Brasil também oferece

\footnotetext{
254 CONTIER, Arnaldo Daraya. Brasil Novo: música, nação e modernidade. Os anos 20 e 30. Tese de livre docência. FFLCH-USP, 1988, pp. XV-XVI.

255 CASTRO, Hebe. Op. cit., p. 81.

${ }^{256}$ CARDOSO, Ciro Flamarion; VAINFAS, Ronaldo (orgs.). Domínios da História: ensaios de teoria e metodologia. Rio de Janeiro: Campus, 1997.

257 FALCON, Francisco. História e poder. CARDOSO; VAINFAS (orgs.). Domínios da História: ensaios de teoria e metodologia. Rio de Janeiro: Campus, 1997, p. 180.
} 
muitos elementos para ser analisada do ponto de vista de uma história política, em geral entendida dentro dos programas de pós-graduação em História como uma linha da História Social.

Ainda que naturalmente existam cruzamentos nestas linhas de pesquisa, para exemplificar, correndo o risco de um certo arbítrio, poderíamos agrupar alguns trabalhos da seguinte maneira:

História Política: Samba da Legitimidade, de Antonio Pedro; Brasil Novo: música, nação e modernidade. Os anos 20 e 30, de Arnaldo Daraya Contier; Uma estratégia de controle: a relação do poder do estado com as Escolas de Samba do Rio de Janeiro no período de 1930 a 1985, de José Luiz de Oliveira; Sinal Fechado: a música popular brasileira sob censura (1935-45 / 1969-1978), de Alberto Moby; Seguindo a canção: engajamento político e indústria cultural na trajetória da música popular brasileira, de Marcos Napolitano.

História Cultural: As sonoridades paulistanas: a música popular na cidade de São Paulo e Metrópole em Sinfonia: história, cultura e música popular na São Paulo dos anos 30, de José Geraldo Vinci de Moraes; Cantores do rádio: a trajetória de Nora Ney e Jorge Goulart e o meio artístico do seu tempo, de Alcir Lenharo; Nas tramas da fama: as estrelas do rádio na sua época áurea. Brasil, anos 40 e 50, de Maria Marta Picarelli Avancini; Jovens tardes de guitarras, sonhos e emoções: fragmentos do movimento musical-cultural Jovem Guarda, de Ana Barbara Aparecida Pederiva; Bossa Nova é sal, é sol, é sul: música e experiências urbanas (Rio de Janeiro, 1954-1964), de Simone Luci Pereira; Brutalidade e jardim: as imagens da nação da tropicália, de José Edson Schümann Lima.

História Social: Capoeiras e malandros: pedaços de uma sonora tradição popular (18901950), Maria Angela Borges Salvadori; Lenço no pescoço: o malandro no teatro de revista e na música popular. "Nacional", "popular" e cultura de massas nos anos 1920, de Tiago de Melo Gomes; Eu não sou cachorro, não: música popular cafona e ditadura militar, de Paulo Cesar de Araújo.

Estudos biográficos: Como observado anteriormente, alguns trabalhos enveredam por uma investigação mais biográfica, que, a partir do estudo de personagens da música popular, procuram articular em torno dos eventos sociais, políticos e culturais de sua 
época uma leitura sócio-histórica de sua produção, ou mesmo, a partir das relações de sua produção com seu momento histórico, tentam entender o contexto no qual ela foi realizada. Naturalmente isto é bem diferente dos trabalhos em torno de autores e obras tão presentes na antiga historiografia da música. Podemos citar nessa linha Custódio Mesquita, um compositor romântico: o entretenimento, a canção sentimental e a política no tempo de Vargas (1930-1945), de Orlando de Barros; Chiquinha Gonzaga no Rio de Janeiro da "Belle Époque": um ensaio de memória, de Cleusa Souza Millan; A dama da boêmia: imagens de Chiquinha Gonzaga, de Lícia Gomes Mascarenhas; Luiz Gonzaga: o migrante nordestino na música popular brasileira, de Antonio Gomes da Silva. E também Cantores do rádio, de Alcir Lenharo, já relacionado com História Cultural.

\subsection{VERTENTES HISTORIOGRÁFICAS EM OUTRAS DISCIPLINAS}

Embora o corpo documental central deste estudo seja a produção historiográfica realizada nos programas de pós-graduação em História, o conceito de historiografia comporta uma concepção mais ampla. Ao mapear a produção historiográfica recente no Brasil na linha da história das ideias, Francisco Falcon apoia-se em Iglésias para priorizar "obras de história" e "estudos sobre obras históricas", deixando em plano secundário a questão do "sujeito historiador". Segundo o autor, essa opção significaria que no lugar da "formação historiadora" seria enfatizada "a intenção de se escrever um trabalho de história e o seu reconhecimento como tal pela comunidade intelectual em geral, e pela historiadora em particular"258. No caso do nosso objeto, também existe uma produção que pode ser considerada historiográfica fora da área de História propriamente dita, a exemplo dos trabalhos de José Miguel Wisnik discutidos no capítulo anterior. A seguir serão mencionados alguns destes trabalhos, como contraponto à produção dos programas de pós-graduação em História, que se acrescentam àqueles que já foram citados durante a exposição da produção historiográfica.

Voz macia: o samba como padrão de música popular brasileira (1917-1939), dissertação de mestrado em Sociologia de Jorge Caldeira, apresenta uma narrativa

258 FALCON, Francisco. História e poder. CARDOSO, Ciro Flamarion; VAINFAS, Ronaldo (orgs.). Domínios da História: ensaios de teoria e metodologia. Rio de Janeiro: Campus, 1997, p. 179. 
histórica sobre um tema polêmico, a afirmação do samba como música nacional. Sua periodização está determinada por duas gravações do samba Pelo Telefone, seu lançamento em 1917 e regravação em 1939, que marcariam "dois momentos de um processo: o surgimento, ainda que de forma imprecisa, de um gênero, e a adaptação dessa criação ao padrão de reconhecimento deste gênero que foi desenvolvido nesse intervalo". 0 autor se propõe a analisar a evolução do samba neste período, tentando entender o caminho que o levou "de uma forma imprecisa a uma fórmula precisa e reconhecida socialmente como manifestação autêntica do povo brasileiro". Caldeira aponta o discurso então recorrente de explicar o samba a partir da ideia que haveria nele "uma verdade social que colocaria criadores autênticos em oposição a um processo que aconteceria no mundo do disco ou da sociedade mais ampla que gira em torno desse universo". Segundo o autor, "a ideia de que o passado das manifestações populares é melhor que o presente é tão antiga como essas manifestações", percepção arguta que permanece válida nos dias atuais. Caldeira discute a ideia da relação do chamado "samba autêntico com o mercado como tradução de um choque entre grupos sociais diversos". ${ }^{259}$ Como apontaram Napolitano e Wasserman, para Jorge Caldeira, é na trajetória da roda do samba para o disco, "pensada a partir de tensões e descontinuidades, que deve ser situada a questão da 'origem' da canção urbana brasileira, baseada no samba como gênero-matriz" . Esta posição afastaria as elaborações de Caldeira "das tendências que buscam enfatizar uma identidade constituída de uma vez por todas, como marca de uma origem, e que vai se perdendo na 'ida ao mercado'”. ${ }^{260}$ Apesar desta visão mais arejada das relações da música com o mercado, Caldeira desenvolve um longo diálogo com as formulações de Adorno, aceitando algumas de suas proposições, como a ideia da estandardização.

Um trabalho de grande influência nesta questão foi a pesquisa de Hermano Vianna, realizada na área de Antropologia, A descoberta do samba: música popular $e$ identidade nacional. Este estudo faz uma análise da transformação do samba em música nacional, como parte de um processo mais amplo de criação da identidade brasileira em torno do debate sobre a miscigenação "racial" e cultural e da valorização da cultura

\footnotetext{
${ }^{259}$ CALDEIRA NETO, Jorge dos Santos. Voz macia: o samba como padrão de música popular brasileira - 1917/1939. Dissertação de mestrado em Sociologia. FFLCH-USP, 1989, pp. 16 e 71-72.

260 NAPOLITANO, Marcos; WASSERMAN, Maria Clara. Desde que o samba é samba: a questão das origens no debate historiográfico sobre a música popular brasileira. Revista Brasileira de História: São Paulo, v.20, no 39, 2000 , p. 184.
} 
popular que ocorreu no Brasil nas primeiras décadas do século XX. O autor procura situar o que ele considera uma invenção da tradição nacional, como um exemplo de uma característica mais geral das "sociedades complexas, nas quais projetos homogeneizadores existem simultaneamente a projetos heterogeneizadores, ano estando necessariamente em oposição entre si”. Entende a nacionalização do samba carioca como uma solução original para esse conflito, privilegiando "mediações transculturais". ${ }^{261}$ Este trabalho foi publicado em livro como O Mistério do Samba e alcançou grande repercussão, sendo muito citado em pesquisas posteriores. Texto polêmico, que se encontra entre os trabalhos que inauguram uma outra vertente na leitura acadêmica acerca do papel do samba na cultura nacional, contrapondo-se à narrativa da autenticidade e resistência, foi criticado, entre outros motivos, pela utilização das elaborações de Gilberto Freyre como instrumental teórico privilegiado para o estudo da questão. ${ }^{262}$

Ainda que não seja o centro da narrativa, esta questão também está presente em Do fundo do quintal á vanguarda: contribuição para uma história social da música popular brasileira, tese de doutorado em Sociologia de José Roberto Zan. 0 trabalho pretende cobrir deste a entrada da indústria fonográfica no Brasil no início do século XX até o tropicalismo, no final dos anos 1960, que, para o autor, encerra um período no qual se "definiram padrões de linguagem da canção em meio à formação de uma indústria cultural e de uma cultura de massas no país". Nesse período, ao desvincularse de suas "raízes folclóricas", a música popular teria passado por um "refinamento" formal e se intelectualizado. 0 autor considera que a música popular, nas décadas de 1930 e 1940, teria mediado "as relações conflituosas entre diversos segmentos sociais e entre o Estado e as massas urbanas”. Já nos anos 1960, “os conflitos entre os diversos

261 VIANNA, Hermano. A descoberta do samba: música popular e identidade nacional. Tese de doutorado em Antropologia, UFRJ, 1994. Citação extraída da publicação da tese: O mistério do samba. Rio de Janeiro: Zahar, 1995, pp. 155.

262 A depreciação de Gilberto Freyre e de sua obra por aqueles que a interpretam como abrandamento de uma estrutura social racista e preconceituosa, que seria sintetizada, para seus detratores, na expressão "democracia racial”, merece reflexão. A crítica das suas posições, levada a cabo por Florestan Fernandes e outros pensadores nos anos 1960, inspirou muitos intelectuais nas décadas seguintes, ainda que desde então tenham sofrido diversas revisões. A partir do final dos anos 1970, a organização e entrada em cena do movimento negro contra a discriminação vai oferecer um espaço político para que setores do movimento apresentem um discurso militante radicalizado sobre a questão. Em que pese a posição de correntes das Ciências Humanas em direção a uma visão mais equilibrada da questão étnica no Brasil, discursos racialistas ainda encontram muito espaço, geralmente vinculados à agendas políticas. Tome-se como exemplo a polêmica em torno das "cotas raciais" nas universidades. Para um histórico do conceito de "democracia racial" e das posições no debate ver GUIMARÃES, Antonio Sérgio Alfredo. Democracia Racial, 2003. Para um histórico do pensamento racial ver: MAGNOLI, Demétrio. Uma gota de sangue: história do pensamento racial. São Paulo: Contexto, 2010. 
segmentos musicais no âmbito do mercado ganharam o caráter de lutas simbólicas entre seus representantes em busca de consagração e de conquista de posições dominantes no interior desse espaço". Para o autor, um setor representado pela bossa nova e pela MPB "tendeu a funcionar nesses anos como referencial para a definição de uma hierarquia de legitimidades no interior do campo. Nesse momento, o tropicalismo, representando o ápice da intelectualização da música popular brasileira" naquele momento, "ao expandir os fluxos entre a produção erudita e a canção de massa, desestabiliza a hierarquia em formação". Zan considera que, "ao fazer a autocrítica da música popular brasileira, libertando seus meios artísticos das amarras ideológicas e estilísticas", o tropicalismo abriu "um amplo espaço para as mais diversas misturas" que iriam se realizar nas décadas seguintes. ${ }^{263}$ Este é o trabalho de mais longo recorte cronológico entre as pesquisas do nosso corpo documental e se propõe apresentar uma narrativa histórico-sociológica para a música popular no Brasil. De um modo geral, existem muito poucas incursões de autores acadêmicos em narrativas de longa duração para a história da música popular, o que faz com que historiadores não acadêmicos como Tinhorão, Ary Vasconcelos e Jairo Severiano ainda se apresentem como alternativas disponíveis para quem procura uma visão panorâmica.

A questão da ascensão social da música e dos músicos populares, ou do setor do campo de produção identificado com a MPB, já havia sido elaborada em $O$ berimbau e o som universal: lutas culturais e indústria fonográfica nos anos 60, dissertação de mestrado em Comunicação de autoria de Enor Paiano. Nesse texto, o autor estuda as relações entre as "lutas simbólicas" e o desenvolvimento, na área da música popular, da indústria de bens culturais nos anos 1960. Sua pergunta inicial é "como a música popular conseguiu passar de uma situação extremamente subalterna" no começo do século XX, para uma situação “onde um certo grupo - em geral identificado com a 'MPB' - conseguiu estatuto de artistas eruditos". A periodização e o foco do trabalho está nos anos 1960. Mas para discutir o período, o autor faz um histórico da posição da música popular na hierarquia de legitimações desde o início dos anos 1930. Paiano considera que "os músicos populares estiveram longamente envolvidos com um processo de 'legitimação' da sua atividade, que, no entanto, só se concretizou nos anos 1960", a

263 ZAN, José Roberto. Do fundo de quintal à vanguarda: contribuição para uma história social da música popular brasileira. Tese de doutorado em Sociologia. IFCH/UNICAMP, 1996, p. 235. 
partir da abordagem dada a duas questões fundamentais:" o compromisso político da arte e do artista, e a relação com o elemento estrangeiro". O autor identifica também a “lógica mercadológica que está por trás de muitas tomadas de posição dos artistas e intelectuais envolvidos com a música popular" e suas relações com a indústria fonográfica em expansão na época, “cuja dinâmica própria facilitou o processo de legitimação de um segmento da música popular". ${ }^{264} 0$ trabalho apresentou elaborações que inspiraram outras pesquisas e foi bastante citado em estudos imediatamente posteriores, a exemplo das teses de Zan e Napolitano. Entretanto, como não foi publicado e o autor não deu continuidade à carreira acadêmica, talvez tenha ficado um pouco esquecido, embora continue sendo um dos textos fundamentais para se discutir a música popular nos anos 1960 e pensar o processo de ascensão social da música e dos músicos populares no Brasil.

Em texto publicado em 1990, Novas bossas e velhos argumentos, ${ }^{265}$ Adalberto Paranhos faz uma ampla análise da bossa nova, que se tornou um importante referencial para a discussão do gênero. 0 autor principia por identificar a vertente defensora da tradição, que ele localiza não apenas nos textos de Tinhorão, mas também em discursos advindos do campo de produção, a exemplo de Elomar, para a seguir historicizar e analisar as principais posições nas interpretações da bossa nova durante os anos 1960. Nesse artigo de fôlego, Paranhos analisou a bossa nova sob múltiplos aspectos: em seus elementos constitutivos, nas informações musicais e de modernidade que ela articulava, nas nuanças de sua performance interpretativa, nas temáticas abordadas no plano narrativo bem como seu sentido coloquial, incorporando também aspectos sonoros e reflexões a partir de uma escuta que não se restringiu ao repertório canônico do gênero. 0 texto analisa também sua recepção nos circuitos de produção e consumo, repercussão internacional, bem como as tendências musicais derivadas da bossa nova ao longo das disputas estético-políticas dos anos 1960. 0 autor concluiu esse panorama da bossa nova, em torno da qual observou também outras

\footnotetext{
264 PAIANO, Enor. Berimbau e o som universal: lutas culturais e indústria fonográfica nos anos 60. Dissertação de mestrado em Comunicação.São Paulo: ECA-USP, 1994, p. 2.

265 PARANHOS, Adalberto. Novas bossas e velhos argumentos: tradição e contemporaneidade na MPB. História \& Perspectivas, no 3. Uberlândia: UFU, 1990, pp. 5-111. Em 2005, Paranhos defendeu sua tese de doutorado em História: Os desafinados: sambas e bambas no "Estado Novo". São Paulo: PUC-SP.
} 
vertentes musicais, com um olhar para a produção então contemporânea, apresentando uma escuta atualizada.

Seria possível ainda elencar, no período, além das pesquisas já mencionadas ao longo deste capítulo como contraponto à produção da área de História, outros trabalhos muito mencionados nos estudos do campo, como: $O$ encontro entre Bandeira \& Sinhô, de André Luís Gardel Barbosa, dissertação de mestrado em Letras, defendida em 1995 e publicada com o mesmo título em 1996;266 O violão azul: modernismo e música popular, tese de doutorado em Sociologia, de Santuza Cambraia Naves, realizada no Instituto Universitário de Pesquisas do Rio de Janeiro, em 1997, e publicada no ano seguinte com o mesmo título; 267 Bim Bom: a contradição sem conflitos de João Gilberto, dissertação de mestrado em Letras, de Walter Garcia, publicada com título homônimo em 1999,268 entre outros.

\subsection{PRINCIPAIS LINHAS TEMÁTICAS NAS PESQUISAS}

Apesar das limitações inerentes a essas classificações, para um olhar panorâmico sobre os temas das pesquisas poderíamos agrupá-las em algumas linhas temáticas gerais. No período que vai até 1999, tiveram especial destaque os estudos envolvendo as relações entre música e política, que pode ser considerada a principal linha de pesquisa, podendo ser mencionados nesta linha os trabalhos de Antonio Pedro, Arnaldo Contier, José Luiz de Oliveira, Carlos Alberto Zeron, Alberto Moby, Marcos Napolitano, Ramon Vilarino e João Ernani Furtado Filho, sendo que outros trabalhos que poderiam ser melhor enquadrados em outras linhas de pesquisa também tangenciam a questão da relações entre música e política, a exemplo das pesquisas de Orlando de Barros e Paulo Cesar de Araújo. Estes estudos de história política estão fundamentalmente centrados em dois momentos cruciais da vida política do país no

\footnotetext{
266 BARBOSA, André Luís Gardel. O encontro entre Bandeira \& Sinhô. Dissertação de mestrado em Letras. UFRJ, 1995. Publicada com título homônimo 1996. Barbosa defendeu sua tese de doutorado em Letras, Aproximações e fugas: a letra do poema e a letra da canção popular brasileira, em 2002 na UFRJ.

267 NAVES, Santuza Cambraia. O violão azul, modernismo e música popular. Tese de doutorado em Sociologia. Instituto Universitário de Pesquisas do Rio de Janeiro, 1997. Publicada com título homônimo em 1998. Naves já havia realizado sua dissertação de mestrado em Antropologia, defendida em 1988 na UFRJ: Objeto não identificado: $a$ trajetória de Caetano Veloso.

268 GARCIA, Walter. Bim bom: a contradição sem conflitos de João Gilberto. Dissertação de mestrado em Letras. FFLCH-USP. Garcia concluiu sua tese de doutorado em Letras na USP, em 2005: Melancolias, mercadorias: Dorival Caymmi, Chico Buarque, o pregão de rua e a canção popular-comercial no Brasil.
} 
século XX: o primeiro governo de Getúlio Vargas e os anos 1960, com os antecedentes do golpe de 1964 e seus desdobramentos no regime militar. Estes foram períodos de efervescência no campo cultural de um modo geral, e musical em particular, que oferecem muitos elementos para se pensar o Brasil. Naturalmente os estudos sobre estes períodos precisam ser conectados com outros momentos que os antecederam e sucederam, como nos mostra a tese de Arnaldo Contier, na qual o estudo da posição dos músicos e intelectuais nacionalistas nos anos 1920 é fundamental para se compreender as posições que estes adoram frente ao governo Vargas.

O tema das "origens" propriamente dito, muito presente na historiografia não acadêmica e em trabalhos de outras áreas, não tem presença marcante nos trabalhos da área de História. Mas diversos trabalhos abordam a constituição de gêneros de música popular, como a tropicália, a jovem guarda e o rock no Brasil. Também os textos de Vinci de Moraes, Iêda Hori e Alberto Ikeda estudam a música popular em São Paulo, na sua constituição inicial e posterior influência da música popular carioca nacionalizada. A elevação do samba carioca à condição de música nacional também é tema de estudos, sendo o centro das pesquisas de Jorge Caldeira e Hermano Vianna.

A elevação do status social da canção e músicos populares é estudada em dois momentos fundamentais, em que é identificado um reposicionamento de setores da música popular na hierarquia de valores culturais: os anos 1930, com o samba sendo alçado à condição de um dos símbolos nacionais e a afirmação de uma visão mais positiva do sambista, e a década de 1960, ao final da qual a produção identificada com a sigla MPB começava a ser vista como produto artístico.

A malandragem é o tema central das pesquisas de Maria Ângela Salvadori e Thiago de Melo Gomes, encontrando-se também como tema secundário em outros estudos. 0 personagem malandro esteve presente também nos estudos pioneiros realizados nas área de Letras e Comunicação, a exemplo da pesquisa de Cláudia Matos. O malandro é um tema e uma questão também: sua caracterização e posicionamento do pesquisador e perante o personagem e seu papel na cultura e na sociedade brasileira.

Uma outra linha temática seriam as questões comportamentais, de juventude, da vida urbana, do cotidiano, de imagens e representações de posições sociais. Temos aqui, por exemplo, os trabalhos de Simone Luci Pereira, sobre a vida urbana no Rio de Janeiro da bossa nova, de Wolney Honório Filho sobre as representações do sertão nas canções caipiras, e os trabalhos sobre a jovem guarda e os primórdios do rock no Brasil. 
Estes são os únicos trabalhos em que a questão de gênero (masculino e feminino) e de juventude aparecem nestas pesquisas que estamos analisando. Estes assuntos são muito presentes na agenda de pesquisas sobre música popular no mundo angloamericano, constituindo uma das principais linhas de pesquisas, até pela característica e história do rock e do pop como manifestações de juventude. Esta agenda dos países de língua inglesa, especialmente Inglaterra e Estados Unidos, só recentemente vem sendo incorporada nos estudos da música popular no Brasil. Uma outra vertente seria o estudo de personagens e gêneros da música popular do ponto de vista de seu posicionamento na cultura nacional.

\subsection{QUESTÕES}

Entre as questões mais frequentemente colocadas, tem destaque a problemática do nacional e do popular na cultura brasileira, o que não é uma particularidade das pesquisas historiográficas no campo da música popular, mas um dos elementos centrais da história da música brasileira como um todo, conforme discutido no início do Capítulo 1.

Na verdade, as discussões acerca do nacional e do popular estão colocadas para a cultura brasileira de um modo geral, para além das polêmicas internas do campo musical. A questão da produção nacional e sua relação com as matrizes internacionais está no centro das discussão sobre a constituição das linguagens artísticas no Brasil, como podemos localizar na formação da literatura brasileira estudada por Antonio Candido ou na atuação dos modernistas, como o demonstram o Manifesto da Poesia Pau-Brasil e o Manifesto Antropófago, de Oswald de Andrade, ou as pinturas de Tarsila do Amaral. No caso da música, o projeto do nacionalismo musical de construção de uma música artística nacional em base ao aproveitamento do material popular - entendido como folclore rural e parcelas da música urbana ainda não deturpada pelas influências estrangeiras, do mercado e da modernidade - esboçou-se no final do século XIX, consolidou-se nos anos 1930 com os textos e atuação de Mário de Andrade, e foi hegemônico na música erudita até meados da década de 1960. Assim, todos os estudos sobre música com características de história social e política que tenham atenção para o campo erudito, a exemplo dos trabalhos de Contier, Zeron e Wisnik, tiveram que se debruçar sobre essa questão. No final do século XIX e começo do XX, o problema da 
identidade nacional ou de como situar o país no contexto internacional estava colocado para as parcelas intelectualizadas da sociedade brasileira. Arnaldo Contier mostra como mesmo aqueles setores das elites paulistanas e cariocas que consumiam música européia procuravam "inserir o Brasil, sob o ponto de vista musical, no interior do concerto das nações civilizadas", ou seja, essa postura, era, a seu modo, também "uma forma de afirmação da brasilidade". ${ }^{269}$ A trajetória de Carlos Gomes (1836-1896), ao fazer sucesso na Itália como compositor de óperas, encarnou essa aspiração, e ele foi adotado como herói nacional. Para Antonio Candido, nacionalismo artístico "é fruto de condições históricas, - quase uma imposição nos momentos em que o Estado se forma e adquire fisionomia nos povos antes desprovidos de autonomia ou unidade". ${ }^{270}$

No começo do século XX, também no campo da música popular se manifesta a questão da identidade nacional. Encontramos essa temática nas pesquisas acerca da malandragem carioca e também nas discussões sobre a afirmação do samba como música nacional e um dos símbolos da brasilidade, por exemplo, nos trabalhos de Jorge Caldeira, Hermano Vianna e Tiago de Melo Gomes. Uma linha de pensamento que se tornou uma referência importante para se abordar a questão do nacional e do popular na história da música no Brasil foi o texto de José Miguel Wisnik, Getúlio da Paixão Cearense, no qual o autor oferece uma visão da questão do erudito e popular na música brasileira mais complexa do que a tradicional oposição dicotômica, articulando essas questões com as da modernidade e do mercado.

Já a expressão nacional-popular remete não apenas à mera conjunção dessas questões, mas a uma determinada vertente do pensamento da esquerda nacionalista brasileira, influenciada pelas formulações de Antonio Gramsci, que reverberavam no Partido Comunista Brasileiro e em diversas das correntes oriundas de seus rachas e divisões. Embora o paradigma nacional-popular tivesse uma perspectiva bem definida dentro da estratégia dos agrupamentos de esquerda que incorporavam essa proposição (que não era o caso dos trotskistas, por exemplo), a expressão pode ter uma acepção mais ampla, como síntese de uma cultura política presente nos meios artísticos e intelectuais do país até os anos 1960, que foi diluindo-se a partir de então. É assim que a expressão nacional-popular aparece em alguns trabalhos na linha de história política,

\footnotetext{
269 CONTIER, Arnaldo Daraya. Brasil Novo: música, nação e modernidade. Os anos 20 e 30 . Tese de livre docência. São Paulo: FFLCH-USP, 1988., p. XLI.

270 CANDIDO, Antonio. Formação da literatura brasileira: momentos decisivos 1750-1880. 12a ed. São Paulo/Rio de Janeiro: FAPESP/Ouro sobre azul, 2009, p. 29.
} 
a exemplo da dissertação de Tiago de Melo Gomes, sem que o conceito esteja claramente explicitado. Marcos Napolitano apresenta em nota uma definição para sua utilização da expressão:

A questão do "nacional-popular", como baliza político-cultural para a esquerda, remete à contribuição teórica de Antonio Gramsci. Para Gramsci o "nacional-popular" estava situado num nível intermediário das expressões culturais de uma coletividade, entre o "provincial-dialetal-folclórico" e os elementos comuns à civilização à qual pertencia a formação social específica. Gramsci pressupunha um "contínuo intercâmbio" entre a "língua popular" e a das "classes cultas", ponto de apoio da cultura "nacional-popular" que visava, no limite, fundamentar a "contra-hegemonia". Conforme suas palavras: "Todo movimento intelectual se torna ou volta a se tornar nacional se se verificou uma 'ida ao povo', se ocorreu uma fase de 'reforma' e não apenas de 'renascimento' (cultural)". Se cotejarmos esta formulação com o processo em questão no Brasil, notamos que a 'ida ao povo' efetivamente norteou a postura dos artistas-intelectuais, sobretudo aqueles ligados à música popular, mas a presença intrínseca da indústria cultural neste processo marcou um movimento de forças contrário a possível afirmação de uma "contrahegemonia". Neste sentido, analisamos a MPB como uma linguagem artística fundada a partir do "nacional-popular", mas não restrita ao sentido político vislumbrado por Gramsci. De qualquer forma, a definição gramsciana é importante para entendermos o projeto inicial desenvolvido pelos artistas mais engajados. ${ }^{271}$

Alguns temas relacionados às leituras da questão do nacional e do popular, mas que tem relevância por si só são o tema da malandragem e a questão da afirmação do samba como padrão de música brasileira. 0 tema da malandragem, presente de maneira secundária em diversos trabalhos, está no centro das pesquisas de Cláudia Matos, Maria Ângela Salvadori e Tiago de Melo Gomes. Desde as primeiras pesquisas realizadas nos anos 1970, vinha se construindo uma imagem positiva do malandro, como contestador das estruturas de dominação presentes na sociedade brasileira, que será questionada na dissertação de Tiago de Melo Gomes, Lenço no pescoço, que propõe uma outra linha de interpretação sobre o malandro em relação à que vinha se desenvolvendo até o momento. Gomes resume, criticamente, da seguinte maneira o que considerou a narrativa então predominante sobre o malandro na música popular:

A história começaria na década de 1880 , quando um imenso contingente de
negros degenerados por anos de trabalho escravo ao se ver livre teria então a
oportunidade de abdicar do trabalho regular, identificado à escravidão.
Passando a viver entre os contingentes marginalizados de cidades como o Rio
de Janeiro, estes negros encontrariam seu meio de expressão no samba, ritmo

271 NAPOLITANO, Marcos. Seguindo a canção: engajamento político e indústria cultural na trajetória da música popular brasileira (1959-1969). Tese de doutorado em História. FFLCH-USP, 1999, p.12. 
oriundo de remotas tradições populares, portanto bastante adequado corno expressão da "voz do povo", nascendo neste momento o samba malandro. Este estilo musical, originado das contradições do pré-capitalismo brasileiro, seria perseguido no período Vargas, devido à seu caráter potencialmente desestabilizador da sociedade capitalista que então se buscava implantar. Para se contrapor ao samba malandro, a máquina ideológica do governo varguista teria produzido o samba exaltação, sempre apontando as grandezas do país e as vantagens de se trabalhar honestamente. Assim, através da censura e do "convencimento" o samba malandro seria afastado do meio musical nos anos do Estado Novo. Após 1945, o samba malandro se tornaria anacrônico, devido à instituição do capitalismo brasileiro, desaparecendo a partir de então. ${ }^{272}$

Gomes considera a publicação da dissertação de Cláudia Matos, o livro Acertei no milhar: samba e malandragem no tempo de Getúlio, um momento crucial na transformação do que ela chamou de "samba malandro" em discurso das camadas oprimidas da sociedade em oposição ao projeto das classes dominantes de implantação do capitalismo no Brasil. Gomes analisa também os textos de Antonio Pedro, Gilberto Vasconcellos e Matinas Suzuki Jr., e considera que, apesar de pequenas diferenças, todos apresentavam o mesmo objetivo:

demonstrar que o malandro foi uma voz incômoda e destoante em relação aos
projetos de dominação impostos pelo estado a partir de 1930 . A partir deste
ponto surge a periodização que busca dar conta de todo o contexto da música
popular existente neste momento: o samba malandro dominaria o cenário
musical até meados da década de 30 , quando a intensificação e o
aperfeiçoamento da máquina de propaganda estatal forçaria o surgimento e a
predominância dos sambas de exaltação ao país, ao governo e ao trabalho. ${ }^{273}$

Esta dicotomia entre samba malandro e samba-exaltação, como dois posicionamentos extremos dos músicos populares frente ao avanço do capitalismo no país e, mais especificamente, perante a ideologia do trabalhismo e a propaganda política do governo Vargas, de fato constituiu uma certa linha de pensamento sobre a música popular no período. Suas limitações foram sendo apontadas por outras pesquisas que se sucederam. Em seu estudo sobre Custódio Mesquita, Orlando de Barros, apesar de aceitar parcialmente essa versão então em voga, fala do foxtrot sem xenofobia, afirmando a influência do gênero no período: "tanto os fox quanto as valsas são tão requeridos nos anos 30 e 40, que alguns compositores, e nem menos Custódio

\footnotetext{
272 GOMES, Tiago de Melo. Lenço no pescoço: o malandro no teatro de revista e na música popular - "nacional", "popular" e cultura de massas nos anos 1920. Dissertação de mestrado em História. Campinas: IFCH-UNICAMP, 1998, p. 4.

${ }^{273}$ Ibidem, p. 14-15.
} 
Mesquita, estavam sempre compondo esses gêneros, ao mesmo tempo que faziam seus sambas e marchas."274 Para o autor, por volta de 1930, já havia pelo menos uma década de forte influência do jazz, em seus variados estilos, que se mesclaram ao maxixe e ao samba nascente.

A exaltação do discurso malandro no samba e da malandragem de um modo geral, por um lado, e a profusão de estudos acerca das lutas culturais dos anos 1960, por outro, tem que ser pensadas em relação ao contexto político no qual esta produção foi realizada. Derrotada política e militarmente na década de 1960, inicialmente com o golpe de estado de 1964 e depois com o a radicalização da ditadura a partir do final de 1968, restou à esquerda a opção de empreender a luta ideológica. Considerada nas suas mais variadas vertentes, a esquerda teve um revés político em 1964 e, depois, nos anos mais duros da ditadura militar, o setor que partiu para a guerrilha sofreu muitas baixas, com a perda de quadros importantes e total derrota militar, assim com os setores que propunham outras vias de enfrentamento ao regime foram vítimas de brutal repressão, com a prisão, tortura e o assassinato de muitos de seus militantes, desmonte de aparelhos e a desorganização de suas estruturas. Mas, ao longo do tempo, sua ideologia foi ganhando espaço na sociedade brasileira. Não importa aqui descrever as múltiplas divisões nem interessa mapear as concepções e os programas de suas distintas correntes. Mas, tomada de conjunto, a esquerda foi bem-sucedida na disputa de ideias. Derrotada militarmente, partiu para a luta política, seja através do chamado "trabalho de base", da militância sindical e estudantil, da organização de movimentos sociais rurais e urbanos ou da participação na política institucional. Constituiu uma máquina de propaganda respeitável e sua ideologia foi ganhando espaço na sociedade ao tempo em que ia ocupando posições institucionais. Um setor das esquerdas em aliança politicamente eclética com antigos adversários e com uma plataforma pragmática chegou ao poder com a eleição de Luís Inácio Lula da Silva, com apoio de parcela expressiva da intelectualidade brasileira.

Segundo Ronaldo Vainfras, "o fato de a universidade ter sido confinada" durante a ditadura militar “como uma espécie de 'gueto' de resistência ao regime”, ao menos no plano intelectual, "fê-la apegar-se aos diversos 'marxismos' disponíveis (do

274 BARRoS, Orlando de. Custódio Mesquita, um compositor romântico: o entretenimento, a canção sentimental e a política no tempo de Vargas (1930-1945). Tese de doutorado em História. São Paulo: FFLCH-USP, 1995, p. 129. 
mais vulgar ao mais sofisticado), sobretudo nos cursos de história". Assim, "as principais temáticas de pesquisa e publicação de fins da década de 1970 foram, grosso modo, as do 'movimento operário' e da 'revolução'”. 275 No caso dos estudos sobre a música popular, duas linhas principais exprimiram essa possibilidade: a) estudar a formação da música popular no Brasil partindo de uma tradição de resistência à dominação; b) estudar os eventos dos anos 1960 e a produção musical dos anos 1970 e seu papel de resistência ao regime militar. Uma parcela significativa das produções pioneiras sobre música popular pode ser olhada por esta perspectiva. Em De olho na fresta, texto de 1975, Gilberto Vasconcellos via um novo significado histórico na "manha da malandragem": o compositor malandro seria aquele que sabe ludibriar o cerco do censor. $^{276}$ Estabelecia-se assim, uma continuidade numa tradição de resistência "malandra", continuidade esta que Maria Ângela Salvadori localizou também entre os capoeiras do final do século XIX e os malandros cariocas dos primeiros anos do século XX. Não por acaso, os dois trabalhos mais emblemáticos entre as primeiras pesquisas acadêmicas sobre música popular, realizados na área de Letras no final dos anos 1970, são Acertei no Milhar, de Cláudia Matos e Desenho Mágico, de Adélia Bezerra de Menezes, o samba como resistência cultural e a MPB como resistência ao regime militar, respectivamente.

Consideremos a expressão música popular brasileira e o acrônimo MPB em relação a esta cultura política nacional-popular. Atualmente é algo aceito e plenamente incorporado pelos pesquisadores da música popular que a sigla MPB não é apenas um abreviatura de música popular brasileira. Embora a sigla MPB seja composta de suas iniciais, ela evidentemente não identifica toda a música popular feita no Brasil, mas um subconjunto desta produção. Esta sigla surgiu num determinado momento histórico, os anos 1960, para designar um repertório que emergia no calor dos festivais e que foi se configurando como um ponto de convergência entre a bossa nova, as canções de protesto, os gêneros tradicionais de música popular no Brasil (samba, baião, marcha) e, num momento posterior, o tropicalismo. Estava em curso um processo de redefinição e atualização da música popular no Brasil iniciado com a bossa nova no final da década

\footnotetext{
275 VAINFAS, Ronaldo. História cultural e história das mentalidades. In: CARDOSO; VAINFAS (orgs.). Domínios da História: ensaios de teoria e metodologia. Rio de Janeiro: Campus, 1997, p. 232.

276 VASCONCELLOS, Gilberto. Música popular: de olho na fresta. Rio de Janeiro, Graal, 1977, p. 72.
} 
de 1950. Era também um momento de impasse da cultura política articulada em torno da ideia do nacional-popular e de reorganização da indústria fotográfica e dos meios de comunicação no país. Todos estes ingredientes entraram na composição estéticoideológica daquilo que veio a ser rotulado de MPB. Vale lembrar também que o acrônimo MPB soava com uma certa similaridade com sigla política, e guardava semelhança com MDB (Movimento Democrático Brasileiro), o partido de oposição consentida no bipartidarismo imposto pelo regime militar, que tinha naturalmente uma característica de frente política. Com o tempo, a sigla foi se institucionalizando e foram se articulando em torno dela novas músicas que surgiam e também parte do repertório anterior aos anos 1960. Assim, por mais que seja uma sigla confortável, é difícil dissociá-la deste caráter instituído.

Se a sigla MPB denomina um setor da música popular feita no Brasil, a expressão música popular brasileira já era utilizada antes da afirmação de seu acrônimo. A expressão tinha, e tem ainda hoje, um sentido agregado que se relaciona a um certo repertório, ainda que mais amplo que a posterior sigla MPB. Ou seja, falar música popular brasileira não é exatamente igual a "música popular feita no Brasil" ou "música brasileira popular": a expressão também está carregada de sentido para além do seu sentido literal. Ecoam na expressão música popular brasileira as concepções sobre o nacional e o popular, tão fortes no Brasil até os anos 1970, bem como uma visão em torno de uma certa linhagem que partiu da música popular carioca - samba-bossa-MPB - que se constituiu num processo que pode ser pensado como de invenção de tradição. ${ }^{277}$ Em muitos trabalhos dos anos 1970 e 1980, podemos encontrar a sigla MPB designando genericamente a música popular feita no Brasil, mesmo aquela realizada antes dos anos 1960, até mesmo o anacronismo de classificar Mário de Andrade de pesquisador da MPB. ${ }^{278}$ Muitos autores não utilizaram a sigla MPB, mas escreveram Música Popular Brasileira, com maiúsculas, durante todo o texto, ou grande parte dele ${ }^{279}$. Em geral, utilizam-se maiúsculas para instituições. Escrever Música

\footnotetext{
277 Por esta razão, temos por vezes evitado utilizar essa expressão neste texto, recorrendo a variações dela, embora isso nem sempre seja possível, pois a expressão é direta e objetiva. Aliás, só é possível essa transmissão de sentido quase subliminar porque a expressão funciona bem, do ponto de vista linguístico. Esse é o caso da expressão "indústria cultural", por exemplo, ou "cultura de massas".

278 CARVALHO. Luiz Fernando Medeiros de. A jura e o critério da platéia no samba de Ismael Silva. Dissertação de mestrado em Letras. PUC/RJ, 1978.

279 Alguns exemplos são: DA MATTA, Gildeta Mattos. Samba, marginalidade e ascensão. Dissertação de mestrado em Filosofia, UFRJ, 1981; SILVA, Antonio Gomes da. Luiz Gonzaga: o migrante nordestino na música popular brasileira.
} 
Popular Brasileira (por extenso e com maiúsculas) já apresentava também um aspecto institucional, que ficava ainda mais forte com a sigla MPB. Enfim, estas três formas de se referir à música popular feita no Brasil (música popular brasileira, Música Popular Brasileira e $M P B$ ) apresentam sentido agregado, embora em proporções distintas.

A percepção da formação da MPB como uma determinada vertente da música brasileira popular já se encontrava no texto clássico de Walnice Nogueira Galvão, MMPB: Uma análise ideológica, de 1968, escrito no momento em que o que viria a ser a MPB estava em gestação. O texto se inicia com a seguinte frase: "A Moderna Música Popular Brasileira apresenta uma proposta nova dentro da tradição". 280 No resto do artigo, a autora vai utilizar apenas a sigla MMPB. Durante os anos 1990, alguns pesquisadores, entre eles Martha Tupinambá de Ulhôa, Alberto Moby, Enor Paiano e Marcos Napolitano, apresentaram trabalhos em que a sigla MPB foi historicizada e analisada sociologicamente. Embora Alberto Moby reivindique a primazia da percepção da carga semântica do acrônimo $\mathrm{MPB}, 281$ e de fato o autor encontra-se entre os primeiros a apresentar uma definição mais restrita de MPB, é difícil precisar quando se definiu pela primeira vez o sentido da sigla, uma vez que sua compreensão foi sendo construída ao longo do tempo em diversas pesquisas. Em Música Popular in Montes Claros, ${ }^{282}$ Martha Ulhôa apresentou uma definição de MPB como um gênero dentro da música popular surgido nos anos 1960, na linhagem do samba carioca e com status social diferenciado, identificando também os principais nomes relacionados com a sigla. De toda forma, o trabalho que mais contribuiu para a fixação de uma concepção do que seja MPB foi Seguindo a canção, de Marcos Napolitano, uma vez que o estudo do gênero estava no centro de sua pesquisa de doutorado. Uma versão mais resumida e específica sobre o conceito encontra-se no artigo $O$ conceito de "MPB" nos anos 60.283

\footnotetext{
Tese de doutorado em História, FFLCH-USP, 1986; PEDERIVA, Ana Barbara Aparecida. Jovens tardes de guitarras, sonhos e emoções: fragmentos do movimento musical-cultural Jovem Guarda. Dissertação de mestrado em História, PUC-SP, 1999; PEREIRA, Simone Luci. Bossa Nova é sal, é sol, é sul: música e experiências urbanas (Rio de Janeiro, 1954-1964). Dissertação de mestrado em História, PUC-SP, 1998.

280 GALVÃO, Walnice Nogueira. MMPB, uma análise ideológica. In Saco de gatos: ensaios críticos. São Paulo, Livraria Duas Cidades, pp. 93-119, 1976, p. 93.

281 MOBY, Alberto. Sinal Fechado: a música popular brasileira sob censura (1937-1945 / 1969-1978). 2ª ed., 2008, p.18. Publicação da dissertação de mestrado em História: Sinal fechado: a música popular brasileira sob censura (1937-45/1969-78). Niterói: UFF, 1993.

282 ULHÔA, Martha Tupinambá de. Música popular in Montes Claros, Minas Gerais, Brazil: a study of middle-class popular music aesthetics in the 1980s. Tese de PhD. Nova York: Cornell University, 1991.

283 NAPOLITANO, Marcos. O conceito de "MPB" nos anos 60. In: História: questões \& debates. Curitiba, PR: Editora da UFPR, ano 16, n. 31, pág. 13 a 30, 1999.
} 
Esta precisão no sentido da expressão $M P B$ tem sua relevância na análise do discurso acadêmico sobre música popular no Brasil, na medida em que, dependendo da concepção que se tenha de MPB, essa generalização da sigla pode ser um indicativo da posição estético-ideológica do autor. Esta carga semântica agregada à expressão MPB não foi inventada em dado momento das pesquisas, caso no qual esta seria uma elaboração a ser refutada, o que até o momento não ocorreu. 0 que ocorreu foi a percepção de um processo histórico, através de uma análise da formação da MPB que deu sustentação teórica para uma coisa que o senso comum já conhecia: antes desta definição acadêmica do sentido de MPB, todo mundo sabia o que ia ouvir quando era convidado para ir a um bar onde tocava MPB. As pessoas tinham inclusive um indicativo do tipo de ambiente, de público e de conversa que iriam encontrar. ${ }^{284}$

Então, se estamos de acordo com uma definição de MPB enquanto uma "instituição sociocultural" com afinidade com uma certa cultura política e um determinado lugar social, como propõe Napolitano, podemos deduzir que sua utilização fora do contexto, anacrônica ou como sinônimo de música popular, tende a implicar uma concepção de música popular associada com aqueles elementos estéticoideológicos agregados à sigla MPB. Sabemos que, com o tempo, parcelas da produção musical brasileira anterior ao surgimento da MPB foram incorporadas a essa tradição ou linhagem de obras "de qualidade" e com "bons posicionamentos" no aspecto político-social. Mas, para um pesquisador, assumir essa incorporação de maneira acrítica indica que ele provavelmente esteja em sintonia com as concepções que a sustentavam. Na verdade, isto apenas reforça o que foi dito anteriormente sobre o peso da esquerda no campo das pesquisas sobre música popular naquele momento.

A questão da mudança da posição social da canção popular urbana no Brasil e de seus compositores e intérpretes, conforme exposto anteriormente, é localizada em dois momentos: a afirmação do samba como símbolo de música brasileira nos anos 1930, com o reposicionamento de seus agentes na hierarquia sociocultural, e a

\footnotetext{
${ }^{284}$ Este trabalho analisa pesquisas realizadas entre 1971 e 1999. Está fora do escopo desta tese discutir essa questão, mas acredito que venha ocorrendo com o tempo uma diluição desta carga semântica da sigla MPB, um alargamento de suas fronteiras estéticas com a incorporação de gêneros antes marginalizados e o esvanecimento de seu aspecto ideológico em função das grandes mudanças do contexto político-social do país. Talvez para o senso comum hoje seu sentido inicial esteja bem enfraquecido, embora ainda não se possa colocar um sinal de igual a "música popular feita no Brasil". Ainda há uma certa expectativa do que se vai ouvir quando se é informado que num determinado lugar "vai tocar MPB".
} 
elevação de um setor da música popular identificado com a MPB à condição de produto artístico no final da década de 1960. Para a discussão do problema histórico da ascensão social do samba e dos sambistas na hierarquia cultural brasileira, a pesquisa de Hermano Vianna, popularizada por sua publicação no livro $O$ mistério do samba, ${ }^{285}$ representou uma contribuição fundamental. Nesse texto, o autor recupera a discussão sobre a mestiçagem presente na obra de Gilberto Freyre, para propor uma interpretação do processo na linha de encontro de culturas, que se contrapunha às narrativas então em voga no meio acadêmico que enfatizavam aspectos da polarização étnica, algumas delas pendendo para um discurso racialista. 0 exemplo mais radical da posição que vinha ganhando força nesta questão é Samba negro, espoliação branca: um estudo das Escolas de Sambas do Rio de Janeiro, ${ }^{286}$ de Ana Maria Rodrigues, onde a espoliação da cultura negra empreendida pelo que a autora chama de "grupo branco" já está no título e o fenômeno da mestiçagem é visto quase como um estratagema desse grupo dominante. ${ }^{287}$

Também o momento e o processo de ascensão social da canção e dos músicos populares apresentam nuanças de interpretação, ainda que, de um modo geral exista acordo de que, por volta da passagem dos anos 1960 para os 1970, já estaria completado um processo de ascensão social de certos setores da canção popular brasileira, cuja produção foi alçada à condição de produto artístico, e seus compositores e intérpretes teriam atingido uma posição social qualitativamente diferente daquela ocupada pelos músicos populares até por volta do final da década de 1950. Entre os trabalhos que contribuíram para fixar esta ideia, já presente de forma ainda embrionária na tese de Celso Favaretto, Tropicália: alegoria, alegria, pode-se mencionar as pesquisas de Enor Paiano, Berimbau e o som universal, de José Roberto Zan, Do fundo do quintal à vanguarda, e de Marcos Napolitano, Seguindo a canção.

Uma polêmica presente em alguns trabalhos é o momento da consolidação do mercado de bens culturais no Brasil, que uns chamam de cultura de massas e outros de

\footnotetext{
285 VIANNA, Hermano. O mistério do samba. Rio de Janeiro: Zahar, 1999. 286 RIBEIRO, Ana Maria Rodrigues. Samba negro, espoliação branca: um estudo das escolas de samba do Rio de Janeiro. Dissertação de mestrado em Ciência Sociais, FFLCH-USP, 1981.

287 Outros trabalhos que abordaram a questão da ascensão social do samba, além dos já mencionados foram: DA MATTA, Gildeta Mattos. Samba: marginalidade e ascensão. Dissertação de mestrado em Filosofia, UFRJ, 1981; PEREIRA, Maria Helena Gisela Ferrari Gomes. Samba: do lazer aos mass media. Dissertação de mestrado em Comunicação, UFRJ, 1979.
} 
indústria cultural, termos sobre os quais nos deteremos no capítulo seguinte. Alguns autores preferem situar a implantação de um mercado cultural massivo no Brasil nos anos 1920 e 1930, com a chegada do rádio e o desenvolvimento das tecnologias de gravação e reprodução do material sonoro. Por exemplo, para Orlando de Barros, a cultura de massa já é um evento nos anos Vargas, considerando seu desenvolvimento paralelo ao crescimento industrial e ao aparelhamento produtivo da sociedade brasileira. Segundo Barros, nos quinze anos do primeiro governo de Getúlio Vargas, tendo o Rio de Janeiro como principal centro emissor, o rádio iria "se firmar, em pouco tempo, como integrante indissolúvel da modernidade que se instaurava no país", transformando-se "em primeiro veículo de massas verdadeiramente pan-nacional".288 Esta posição se contrapõe às elaborações de Renato Ortiz, que considera os anos 1940 e 1950 "como momentos de incipiência de uma sociedade de consumo" e situa a "consolidação de um mercado de bens culturais" no Brasil nas décadas de 1960 e 1970.289

Após esta apresentação panorâmica da produção historiográfica sobre música popular urbana, que teve por objetivo identificar as temáticas, enfoques e os conteúdos centrais das pesquisas, nos próximos capítulos serão observados os principais conceitos presentes nesses estudos e as teorias em que se fundamentam, a seleção e utilização do material sonoro como fonte de pesquisas e as questões metodológicas colocadas nas relações entre história e música.

\footnotetext{
288 BARRoS, Orlando de. Custódio Mesquita, um compositor romântico: o entretenimento, a canção sentimental e a política no tempo de Vargas (1930-1945). Tese de doutorado em História. São Paulo: FFLCH-USP, 1995, p .33.

289 ORTIZ, Renato. A moderna tradição brasileira: cultura brasileira e indústria cultural. São Paulo: Editora Brasiliense, 1988, p.113.
} 


\title{
CAPÍTULO 4 \\ CONCEITOS E TEORIAS: UM OLHAR PANORÂMICO
}

\begin{abstract}
Fazer história dos processos implica fazer história das categorias com que os analisamos e das palavras com que os nomeamos. Lenta mas irreversivelmente viemos aprendendo que o discurso não é um mero instrumento passivo na construção do sentido que tomam os processos sociais, as estruturas econômicas ou os conflitos políticos. E que há conceitos tão carregados de opacidade e ambigüidade que só a sua historicização pode permitir-nos saber de que estamos falando mais além do que supomos estar dizendo. ${ }^{290}$
\end{abstract}

Este capítulo está dedicado a um olhar panorâmico para os principais conceitos empregados na historiografia acadêmica da música popular dentro da periodização deste estudo, bem como as teorias em que se fundamentam. Entre os conceitos que mais frequentemente informaram e direcionaram o debate estão os de indústria cultural, hegemonia, intelectual orgânico, invenção da tradição, campo, representação, prática, apropriação, estratégia, tática e circularidade cultural. Estes conceitos podem ser considerados representativos e pertencentes a dois paradigmas dominantes na interpretação da história: o marxismo, em suas distintas vertentes, especialmente nas tendências que se convencionou chamar de marxismo ocidental, por um lado; e a Nova História, como continuidade da escola dos Annales, e os historiadores e cientistas sociais que pensaram a história da cultura e influenciaram ou dialogaram com suas posições, por outro. Também podem ser localizados conceitos oriundos do marxismo clássico, ou ortodoxo, como luta de classes, burguesia, pequenaburguesia, proletariado, mais valia, modo de produção, forças produtivas e alienação, cuja utilização, no sentido forte, em estudos da cultura, está associada à concepção da determinação da superestrutura pela base. Estes conceitos, que foram mais presentes no ensaísmo dos anos 1970 e 1980, aparecem também em algumas das primeiras pesquisas historiográficas, mas sua incidência tendeu a decrescer ao longo do tempo.

Antes de entrar no assunto propriamente dito, uma breve consideração geral. A circulação destes e outros conceitos, sem dúvida úteis e necessários para a discussão, na medida em que sintetizam numa única palavra ou expressão todo um conjunto de

290 MARTín-BARBERO, Jesús. Dos meios às mediações: comunicação, cultura e hegemonia. 4⿳亠丷a ed. Rio de Janeiro: Editora UFRJ, 2006, p.31. 
ideias complexas, apresenta um efeito colateral negativo, qual seja, a apropriação de certas palavras do léxico, cuja utilização fora de sua conceitualização poderia levar a interpretações ambíguas. Hegemonia é um destes casos. Outros exemplos poderiam ser indústria cultural e campo, para citar formulações de elaborações teóricas distintas. Se essas expressões são usadas no sentido fraco, sem o peso do conceito a elas incorporado, isso em certos contextos pode resultar num ruído na comunicação. Assim, por vezes somos obrigados a esclarecer em que sentido estamos utilizando certas palavras ou expressões ou correr o risco de interpretações dúbias. Por exemplo, todas as vezes que a palavra hegemonia aparece neste trabalho está utilizada no sentido literal, dicionarizado, não incorporando o conceito gramsciano. Hegemonia é uma palavra muito útil para ser sequestrada por uma acepção limitada, tanto mais que não contamos com outra palavra em português que tenha o mesmo significado (supremacia, preponderância, predominância, superioridade ou liderança tem outras conotações). A palavra campo, quando não indicado enquanto o conceito de Pierre Bourdieu, estou utilizando num sentido mais fraco do aquele adquirido na sua sociologia. Já a expressão indústria cultural parece mais difícil de desincorporar o sentido adorniano e ser utilizada de forma mais genérica, razão pela qual está sendo evitada neste texto, com preferência para a expressão mais longa mercado de bens culturais.

Segundo Vainfas, "a Nova História tardou muito a penetrar no âmbito da historiografia brasileira, só o fazendo, a rigor, a partir de meados da década de 1980". Para o autor, "as razões dessa demora não devem ser buscadas num suposto atraso de país de 'terceiro mundo', que só com grande defasagem absorve os 'modismos estrangeiros'”. Entre os elementos para se entender essa defasagem Vainfas arrola diversos fatores interligados, como o regime militar e a transformação da universidade "numa espécie de 'gueto' de resistência” com presença marcante dos diversos marxismos, o mercado editorial, que só a partir de meados dos anos 1980 vai publicar traduções de obras fundamentais, e a juventude dos cursos de pós-graduação em 
história, que com exceção da Universidade de São Paulo, estavam apenas começando no Brasil a partir dos anos 1970.291

De fato, é marcante a presença de posições marxistas, ou de "visões genericamente marxistas", conforme a expressão de Falcon, ${ }^{292}$ nos primeiros trabalhos de nosso corpo documental e também em outras pesquisas sobre música popular no período. Pode-se notar uma incidência maior de conceitos oriundos do marxismo nas pesquisas dos anos 1980 e inícios dos anos 1990, que vai decrescendo ao longo da década. Ainda que exista claramente esta tendência decrescente, ao menos no período que estamos analisando, a terminologia clássica do ideário marxista foi utilizada em larga escala. Até o final dos anos 1990, foram frequentemente empregados nas pesquisas sobre música popular conceitos como: luta de classes, burguesia, pequenaburguesia, proletariado, lumpemproletariado, valor de uso, valor de troca, mais valia, modo de produção, forças produtivas e alienação, além, é claro, do fetichismo na música conforme a expressão de Adorno derivada do fetichismo da mercadoria de Marx. Estes termos atualmente apresentam um certo sentido nostálgico, cerca de 150 anos depois de terem sido cunhados para a análise do capitalismo em ascensão, mas ainda estão em plena atividade. Nem sempre os trabalhos onde estes conceitos aparecem podem ser classificados como marxistas, no sentido forte. Talvez sua utilização reflita mais o "espírito do tempo", o peso do marxismo na intelectualidade brasileira no momento da realização dos trabalhos, uma vez que eram empregados com naturalidade, sem que a utilização deste jargão implicasse numa aceitação, ao menos de maneira global, do ideário marxista como referencial teórico claramente definido. Estes conceitos estavam presentes no ambiente da universidade brasileira, e na intelectualidade de um modo geral, como um senso comum acadêmico. Era um marxismo de fundo, um background marxista que nem sempre vinha para o primeiro plano.

Entre as pesquisas que trabalham com os conceitos de luta de classes, denominações de classes como burguesia, pequena-burguesia e proletariado, ou derivados (como ordem constitucional burguesa, padrão liberal burguês, gosto pequeno-burguês, léxico pequeno-burguês) podemos citar Samba da Legitimidade, Luiz

\footnotetext{
291 VAINFAS, Ronaldo. História cultural e história das mentalidades. In: CARDOSO; VAINFAS (orgs.). Domínios da História: ensaios de teoria e metodologia. Rio de Janeiro: Campus, 1997, p.231-232.

292 FALCON, Francisco. História e poder. In: CARDOSO; VAINFAS (orgs.). Domínios da História: ensaios de teoria e metodologia. Rio de Janeiro: Campus, 1997, p.127.
} 
Gonzaga, o migrante nordestino na música popular brasileira, Brasil Novo: música nação e modernidade, Capoeiras e malandros, Sinal fechado, Custódio Mesquita, um compositor romântico, A MPB em movimento, Uma estratégia de controle: a relação do poder de estado com as Escolas de Samba do Rio de Janeiro, Chiquinha Gonzaga na Bélle Époque. Entre estas, há aquelas que aplicam esta terminologia no sentido forte, e outras de uma maneira menos rígida, sem a carga semântica do marxismo ortodoxo.

Dos conceitos acima mencionados, apenas a palavra burguesia não é exclusiva da tradição marxista, designando originalmente os habitantes dos burgos, as pequenas cidades surgidas durante a Idade Média, dedicados ao comércio como atividade econômica e vistos com 1esprezo pela nobreza. Por extensão, pode designar as classes médias surgidas na Europa por volta do fim do período medieval. Mas, a partir de sua utilização por Marx e Engels, a palavra está carregada de sentido agregado e, atualmente, é muito difícil falar em burguesia de uma maneira desvinculada da ideia da classe detentora do poder econômico e dirigente na sociedade capitalista. Aqui, entretanto, já há uma adaptação, uma vez que, na concepção marxista original, burguesia era a classe detentora dos meios de produção e exploradora da força de trabalho do proletariado. Hoje não é mais necessário ser detentor de meios de produção e explorador de um "proletariado" cada vez mais reduzido, para ser classificado como pertencente à "burguesia".

Mas se burguesia já é um conceito ambíguo que talvez fosse melhor ser evitado, consideremos então o conceito de pequena burguesia. 0 pequeno-burguês seria um resquício de um momento anterior do desenvolvimento econômico da sociedade europeia, que, afrontado nos seus interesses pelas imensas e revolucionárias transformações socioeconômicas empreendidas pela burguesia, queria, como os demais estados médios da sociedade, fazer girar para trás a roda da história. ${ }^{293}$ Assim, esta categoria, a rigor, não seria adequada para as modernas classes médias urbanas do século XX, podendo, forçando um pouco, ser aplicada a certos setores delas, os comerciantes e pequenos produtores. Mas em geral esta expressão não aparece utilizada num sentido socioeconômico, mas numa perspectiva estético-cultural: gosto pequeno-burguês, sentimento pequeno-burguês, projeto de vida pequeno-burguês.

293 MARX, Karl; ENGELS, Friedrich. Manifesto do Partido Comunista. Disponível em: <www.dominiopublico.gov.br>. Acesso em 17 de outubro de 2010. 
Observe-se que, em certos setores da esquerda radical no Brasil, o termo adquiriu um forte sentido pejorativo: caracterizaria um ser mesquinho e provinciano, que remonta ao reacionário que queria girar para trás a roda da história. Nesse sentido, como xingamento, é pior que burguês: o burguês é odiado, o pequeno-burguês é desprezível.

A utilização constante desta terminologia no sentido forte aponta para uma visão da cultura como cultura de classes, reflexo da luta de classes, que seria o motor da história. Tinhorão apresentou com toda clareza esta concepção ideológica, conforme discutido no Capítulo 1, que vem inevitavelmente acompanhada de dogmáticas valorações estéticas. Esta visão da música como reflexo da sociedade está também formulada de maneira explícita por Antônio Gomes da Silva, em texto de 1986:

E uma vez reconhecida a condição de produto resultante da atuação cotidiana e de práticas históricas de determinados grupos ou classes sociais, torna-se fácil ainda depreender logicamente, mas não de forma meramente mecanicista, que tanto a música como aquele que a compõe refletem as condições materiais e não-materiais de existência; as atitudes; os valores; as crenças e as idéias dos grupos ou classes sociais dos quais são tidos como representantes e com os quais direta ou indiretamente se relacionam..$^{294}$

O autor trabalha com uma ideia de "povo" ou "massas populares" como as classes e grupos sociais que num dado contexto histórico resolvem as tarefas de desenvolvimento progressista da sociedade. Nesta concepção, a burguesia nacional, quando luta com os trabalhadores contra o colonialismo, deve ser incluída no povo, mas quando luta contra o seu próprio povo, perde o direito de se chamar povo. ${ }^{295}$ Silva considera que Luiz Gonzaga representa a expressão mais coerente possível do grupo ou classe social que lhe deu origem. Existe um descompasso nesta tese entre as premissas teórico-metodológicas e o desenvolvimento e conclusões do trabalho. 0 texto apresenta um discurso ideológico de esquerda, stalinista, situando a arte como expressão de uma classe social, para depois enveredar por um trabalho biográfico apologético sobre Luiz Gonzaga, no qual os esforços para colocá-lo como representante das classes populares resultam não convincentes. Parece existir certo esforço em compatibilizar um personagem distante do ideário de esquerda com as concepções do artista como representante do povo na sua luta pela emancipação. É uma contradição que a

\footnotetext{
294 SILVA, Antonio Gomes da. Luiz Gonzaga: o migrante nordestino na música popular brasileira. Tese de doutorado em História. FFLCH-USP, 1986.

295 Ibidem, pp.73-74.
} 
indústria de bens culturais seja sempre criticada ao longo do texto, mas Luiz Gonzaga, um artista cuja produção está intimamente ligada à indústria, seja reverenciado. Esta combinação de marxismo ortodoxo com a valorização das coisas nordestinas como sinônimo de povo que norteia o trabalho chega ao extremo de um elogio absurdo ao cangaceiro Virgulino Ferreira da Silva, o Lampião. Antonio Gomes da Silva considera que até Lênin o elogiaria como estrategista e saúda: "Saravá agora não só para Luiz Gonzaga de novo, mas também para Virgulino Ferreira, o grande guerrilheiro nordestino Lampião". 296

Antonio Pedro, em 1980, atuando no plano da análise do discurso do texto literário, via o compositor popular como um produtor de canções que veiculam uma ideologia, no sentido marxista do termo (entendida como concepção de mundo das classes dirigentes a difundir-se para outros setores da sociedade), não importando assim se o fazia consciente ou inconscientemente. 0 autor considerava, na época, que o conjunto das classes subalternas não possuem exatamente uma concepção de mundo elaborada ou organizada, o que, em última instância, daria subsídios para compreender a penetração de ideologias "estranhas". Cita como exemplo a canção É Negócio Casar, de Ataulfo Alves e Felisberto Martins, canção de 1941 que veicularia "uma ideologia necessária às classes dirigentes para legitimar ao nível da superestrutura o processo de acumulação do capital", nas palavras do autor. ${ }^{297}$

Num trabalho mais recente, de 1998, também numa linha determinista, guiada pela "teoria do reflexo", Vilarino, classificou a MPB como um movimento no interior da música popular brasileira que travou o bom e necessário combate. 0 autor afirma que procurou demonstrar em sua pesquisa como numa sociedade de classes, cindida entre exploradores e explorados, há uma disputa por posições, lugares e situações, onde o que está em jogo, em última instância, é, de um lado, a permanência ou até o aumento dessa exploração e, de outro, a diminuição ou o fim dessa condição. ${ }^{298}$

As expressões valor de uso, valor de troca, mais-valia, modo de produção e forças produtivas aparecem nas pesquisas de uma maneira residual (por exemplo, valor de uso e de troca, forças produtivas em Dança Dramática, modo de produção em Uma

\footnotetext{
296 Ibidem, p. 284.

297 TOTA, Antonio Pedro. Samba da legitimidade. Dissertação de mestrado em História, FFLCH-USP, 1980, p. 12.

298 VILARINO, Ramon Casas. A MPB em movimento: música, festivais e censura. São Paulo: Olho d’Água, 1999 , p. 6-7.
} 
estratégia de controle, mais-valia em Custódio Mesquita). Tratam-se de conceitos que dizem respeito à ciência econômica, vinculados à tradição marxista na disciplina. Que as coisas tenham valor de uso e valor de troca, por exemplo, não constitui em si nenhuma novidade, é algo que podemos aceitar com tranquilidade, difícil até de ser contestado. Mas tal como estão articulados em 0 Capital, como parte de um esforço de compreensão e explicação do funcionamento estrutural do sistema capitalista, adquirem um sentido agregado. Ou seja, utilizadas de passagem, com minúsculas, as expressões valor de uso e valor de troca, podem não ter um significado que extrapole o seu sentido literal. Mas dentro de um contexto de observação da música como mercadoria, por vezes com maiúsculas, somos inevitavelmente remetidos ao estudo que Marx fez da produção de mercadorias no capitalismo, como geradora de mais-valia apropriada pelos detentores dos meios de produção e exploradores da força de trabalho alheia.

A vertente do marxismo mais influente nos estudos historiográficos da música popular é aquela que se convencionou chamar de marxismo ocidental, ${ }^{299}$ representada, num primeiro momento, nos trabalhos produzidos por Gramsci, Lukács e pelos membros da chamada Escola de Frankfurt, Adorno, Benjamin, Horkheimer e Marcuse, e, posteriormente, em pensadores de distintas vertentes, como Sartre e Althusser, historiadores britânicos como Eric Hobsbawm, Perry Anderson, Edward P. Thompson e outros reunidos em torno da New Left Review, setores da historiografia francesa, além de intelectuais de outras áreas das ciências humanas, como Raymond Williams e Stuart Hall. ${ }^{300}$ A estes nomes podem se somar os de Benedict Anderson, Frederic Jameson e Terry Eagleton, entre outros. No Brasil, constituiu-se uma influente vertente de pensadores de esquerda, num sentido amplo do termo, entre os quais Florestan Fernandes, Fernando Henrique Cardoso e Antonio Candido. Todos estes nomes, citados em diversas das pesquisas que este trabalho procura analisar.

Dentro do amplo campo do que se pode chamar de marxismo ocidental, ou seja, de posições independentes da ortodoxia marxista, com conflitos e contradições e sem homogeneidade teórica, situam-se também os Cultural Studies anglo-americanos.

\footnotetext{
299 ANDERSON, Perry. Considerações sobre o marxismo ocidental. 2ª ed. São Paulo: Editora Brasiliense, 1989. 300 FALCON, Francisco. História e poder. In: CARDOSO; VAINFAS (orgs.). Domínios da História: ensaios de teoria e metodologia. Rio de Janeiro: Campus, 1997, p.112.
} 
Segundo Tânia Garcia, os autores identificados com esta vertente fazem uma revisão da teoria marxista, rompendo com o pressuposto de que a superestrutura é determinada pela base, ou seja, a cultura não seria simplesmente resultado de um modo de produção que moldaria a "sociedade impondo modelos de conduta e comportamentos". Na linha de pensamento dos Estudos Culturais Ingleses, haveria "uma interação dinâmica entre a estrutura e a superestrutura, descartando o domínio de uma sobre a outra. Partem da existência de uma experiência anterior, que reage de forma plural a tais estruturas, e cujos desdobramentos" não seriam possíveis de prever. ${ }^{301}$

Se observarmos o peso dos discursos adornianos nas pesquisas sobre música popular, somados à ampla utilização dos conceitos acima mencionados, e às muitas citações de autores marxistas mais contemporâneos e renovados, como Williams, Thompson, Bakhtin e Hobsbawm, dos Estudos Culturais Ingleses, além da influência da obra de José Ramos Tinhorão, podemos concluir que a incidência do marxismo é grande na historiografia acadêmica (e não-acadêmica) até o final dos anos 1990, e mesmo majoritária, se considerarmos o conjunto dos estudos sobre música popular realizados nas diversas áreas do conhecimento, considerando-se a forte presença destas ideias nos trabalhos realizados na área de Letras, Comunicação e Sociologia nos anos 1970 e 1980. De fato, de um modo geral, até hoje é marcante a presença das ideias de esquerda na universidade brasileira, especialmente na área das Ciências Sociais e Humanidades.

Feitas estas considerações de caráter mais geral, vamos observar mais de perto alguns dos conceitos desenvolvidos por pensadores do marxismo ocidental mais presentes nas pesquisas sobre música popular. No Capítulo 2, afirmei que, em relação aos referenciais teóricos, o principal corte em que os trabalhos realizados na década de 1970 e 1980 poderiam ser divididos, seria entre os que ecoavam concepções adornianas, particularmente o conceito de indústria cultural e a visão da música popular como mercadoria estandardizada, por um lado, e, por outro, aqueles que buscavam outros referenciais. Estes outros referenciais foram, num primeiro momento, principalmente Umberto Eco e Edgard Morin. Walter Benjamin, apesar de identificado

\footnotetext{
301 GARCIA, Tânia da Costa. Reconfigurações identitárias, meios de comunicação de massa e cultura jovem na América Latina na segunda metade do século XX. In: BARBOSA; GARCIA (orgs.). Cadernos de Seminários de Pesquisa: Cultura e Políticas nas Américas. Vol. 1. Assis: FCL/Assis-Unesp Publicações, 2009, p. 108.
} 
com a chamada Escola de Frankfurt, oferece outras possibilidades para a leitura da arte no século XX em relação às análises propostas por Theodor Adorno. Estes autores continuaram a ter grande influência e ser objeto de reflexão nas pesquisas até os anos 1990, e até hoje ainda reverberam suas posições, razão pela qual se justifica um olhar mais aproximado.

0 conceito mais polêmico entre aqueles mais frequentemente encontrados nos estudos sobre música popular foi (e talvez ainda seja) o de indústria cultural. 0 conceito aparece em distintas condições: adotado como referencial teórico, num sentido forte, adorniano; utilizado de uma maneira mais genérica e flexível, num sentido fraco; e contestado enquanto conceito válido. Trata-se de uma expressão flexível, compreensiva e abrangente, mas que ficou marcada pelo rigor normativo adorniano. Poderia ser utilizada sem polêmica se apenas designasse a produção em larga escala de bens culturais, desvinculada do sentido que adquiriu a partir das elaborações de Adorno e Horkheimer. Existe de fato uma indústria cultural, no sentido de um setor de produção em larga escala para o mercado de bens culturais. Faz parte da lógica do nosso sistema econômico que os bens culturais sejam vendidos no mercado e que empresas se organizem, como nos demais ramos de atividade econômica, para melhor explorá-los do ponto de vista comercial, gostemos ou não deste fato. Com a internacionalização do mercado, como em outros ramos da economia, empresas multinacionais passaram a controlar a comercialização de bens culturais em larga escala. Em todas as sociedades que nos precederam, a produção artística se desenvolveu em intrínseca relação com a forma de organização da vida material dessas sociedades. A ideia da autonomia total da arte, desvinculada das condições objetivas da vida material, constitui uma abstração teórica.

Assim, poder-se-ia falar de indústria cultural num sentido fraco, numa acepção mais descongestionada, para usar a expressão de Umberto Eco. ${ }^{302} \mathrm{O}$ termo foi utilizado por outros pensadores, como Edgar Morin em Cultura de Massas no Século XX: O Espírito de Tempo, ${ }^{303}$ por exemplo, no sentido de cultura industrial que em nada se relaciona com a concepção proposta por Adorno, que nem é citado. Mas a expressão está carregada de sentido agregado e é difícil falar de indústria cultural sem que nos

302 ECO, Umberto. Apocalípticos e Integrados. 6⿳a ed. São Paulo: Perspectiva, 2004, p. 7.

303 MORIN, Edgar. Cultura de Massas no Século XX. Rio de Janeiro: Editora Forense Universitária, 1997. 
remetamos às proposições formuladas por Adorno. Seria assim, um exemplo do que Umberto Eco em Apocalípticos e Integrados chamou de conceitos-fetiche. ${ }^{304}$ No texto de Eco, que se tornou uma referência para a sociologia da comunicação, a fórmula apocalípticos e integrados ironizava duas posições extremadas perante os novos fenômenos da comunicação massiva, viabilizada pelo desenvolvimento tecnológico. 0 apocalíptico é o inconformado diante da aberração e pessimista quanto ao caráter irremediável da decadência da cultura; o integrado é aquele que, despreocupado da questão da cultura vir de baixo ou imposta de cima para consumidores indefesos, opera, produz e emite suas mensagens cotidianamente em todos os níveis. Eco observa que foram os mesmos que ele denomina de apocalípticos ou integrados os responsáveis pela difusão de categorias genéricas que ele chamou de conceitos-fetiche, que teriam a particularidade de bloquear o discurso, enrijecendo o colóquio num ato de reação emotiva. Umberto Eco considerava a difusão das categorias-fetiche o obstáculo maior a uma pesquisa concreta sobre os fenômenos da produção e consumo da cultura.

Nos trabalhos do nosso corpo documental é possível identificar um enfraquecimento progressivo das ideias adornianas em relação ao ensaísmo dos anos 1970 e 1980. Por vezes a expressão indústria cultural é usada de uma forma mais genérica, como em Uma estratégia de controle, de José Luiz de Oliveira e Chiquinha Gonzaga no Rio de Janeiro da Bélle Époque, de Cleusa Millan, sem que o conceito tenha um papel central na análise. Mesmo num trabalho como Seguindo a canção: engajamento político e indústria cultural na trajetória da música brasileira, de Marcos Napolitano, onde o tema do mercado de bens culturais no Brasil dos anos 1960 é uma problemática que está no centro da pesquisa, o autor trabalha com mediações em relação às formulações de Adorno, direcionando o debate para as manifestações específicas da indústria no Brasil. Em Sinal Fechado, Alberto Moby se refere à "chamada indústria cultural". Orlando de Barros critica a Escola de Frankfurt por suas restrições em relação à cultura de massas. Já em Voz Macia: o samba como padrão de música brasileira, de Jorge Caldeira, as ideias adornianas têm um papel mais destacado: a pesquisa parte da "hipótese de que o gênero, ao ganhar forma num processo

\footnotetext{
${ }^{304}$ ECO, Umberto. Apocalípticos e Integrados. 6ª ed. São Paulo: Perspectiva, 2004, p.11-16.
} 
intermediado por uma indústria cultural, sofreu uma estandardização". ${ }^{305}$ Caldeira vai concluir que o samba foi estandardizado, num processo que guarda semelhanças e distinções com aquele descrito por Adorno. Um exemplo mais recente de encampação plena e defesa explícita dos conceitos adornianos, encontra-se em Os donos da voz: indústria fonográfica brasileira e mundialização da cultura $^{306}$, trabalho relativamente recente que teve ampla circulação. Tosta Dias inicia o primeiro capítulo com o item $A$ atualidade do conceito de indústria cultural. Anos antes, Paulo Puterman havia escrito uma tese de doutorado dedicada a questionar o conceito de indústria cultural, publicada com o título de Indústria Cultural: a agonia de um conceito. ${ }^{307}$ Entretanto, o autor não conseguiu dar o golpe de misericórdia, uma vez que o trabalho não dá conta de toda a complexidade do conceito e das exigências críticas em torno dele, tomando-o como mera noção valorativa e expressão dos preconceitos de Adorno, aspectos pertinentes, mas que não esgotam a questão.

Outras proposições de Adorno presentes em diversas pesquisas são aquelas apresentadas no texto $O$ fetichismo na música e a regressão da audição. ${ }^{308}$ A ideia do fetichismo na música, decorrente de sua condição de mercadoria, por exemplo, está incorporada na dissertação de mestrado de Carlos Alberto Zeron, que o apresenta da seguinte maneira:

\begin{abstract}
Entendemos aqui a noção de "fetichismo" na música como derivada do conceito de fetichismo da mercadoria em Karl Marx, definida no primeiro volume d'O Capital, qual seja, o de que a forma mercadoria devolve aos homens as características sociais realizadas no processo de trabalho como caracteres dos próprios produtos do trabalho, como propriedades naturais e sociais inerentes a esses produtos; em conseqüência, a forma mercadoria reflete também a relação social dos produtores com o processo de trabalho global como uma relação social de objetos existentes fora deles. Ver, sobre esse aspecto, o ensaio de Theodor W. Adorno "O fetichismo na música e a regressão da audição", de 1938, que desenvolve esses aspectos. ${ }^{309}$
\end{abstract}

\footnotetext{
305 CALDEIRA NETO, Jorge dos Santos. Voz macia: o samba como padrão de música popular brasileira (1917/1939). Dissertação de mestrado em Sociologia. FFLCH-USP, 1989, p. 17.

306 DIAS, Márcia Tosta. Os donos da voz: indústria fonográfica brasileira e mundialização da cultura. São Paulo: Boitempo Editorial, 2000. Publicação da dissertação de mestrado em Sociologia: Sobre mundialização da indústria fonográfica: Brasil. Anos 70-90. Campinas: IFCH/UNICAMP, 1997.

307 PUTERMAN, Paulo. Indústria cultural: a agonia de um conceito. São Paulo: Perspectiva, 1994. Publicação da tese de doutorado em Sociologia: Indústria cultural: indústria ou cultura? São Paulo: FFLCH-USP, 1993.

308 ADORNO, T. W. O fetichismo na música e a regressão da audição. In: Os Pensadores: Benjamin, Habermas, Horkheimer e Adorno. 2º ed. São Paulo: Abril, 1983, p.165-191.

309 ZERON, Carlos Alberto de Moura Ribeiro. Fundamentos histórico-políticos da música nova e da música engajada no Brasil a partir de 1962. Tese de doutorado. São Paulo: FFLCH-USP, 1991, p.4.
} 
A aceitação e aplicação desses conceitos estão diretamente vinculadas a uma visão marxista da sociedade, seja ela plenamente assumida e explicitamente formulada, como na passagem acima, ou como posições genericamente marxistas. Para Adorno, a música atual, na sua totalidade, à exceção da música das vanguardas que teriam se tornado independentes do consumo, seria dominada pela característica de mercadoria. No polo oposto do fetichismo da música decorrente de sua condição de mercadoria se operaria a regressão da audição.

A produção musical avançada se independentizou do consumo. 0 resto da música séria é submetido à lei do consumo, pelo preço de seu conteúdo. Ouvese tal música séria como se consome uma mercadoria adquirida no mercado. Carecem totalmente de significado real as distinções entre a audição da música "clássica" oficial e da música ligeira. Os dois tipos de música são manipulados exclusivamente à base das chances de venda; deve-se assegurar ao fã das músicas de sucesso que os seus ídolos não são excessivamente elevados para ele. ${ }^{310}$

Realmente a música de vanguarda adquiriu autonomia em relação ao consumo, mas às custas de uma espécie de mecenato contemporâneo. No Brasil, particularmente, é fato por todos reconhecidos que a quase totalidade dos compositores eruditos contemporâneos atua no ensino de composição e teoria musical nos departamentos de música das universidades públicas e não temos nenhuma razão para acreditar que isso seja diferente no plano internacional. Toda a produção musical que não estiver amparada por alguma forma de suporte institucional terá que se submeter às "leis do consumo". Não há realmente outra possibilidade e isto não constitui uma exclusividade da nossa época. ${ }^{311}$

Como apontou Sean Stroud, "considerando a grande demanda global para a

\footnotetext{
310 ADORNO, T. W. O fetichismo na música e a regressão da audição. In: Os Pensadores: Benjamin, Habermas, Horkheimer e Adorno. 2º ed. São Paulo: Abril, 1983, p.165-191.

311 James Lincoln Collier, polemizando com o artigo Who Cares If You Listen?, no qual Milton Babbitt sustentou a posição de que, assim como a filosofia moderna e a física moderna, a cadeira de composição musical tinha se tornado tão misteriosa que não há qualquer esperança de que mesmo um público razoavelmente culto possa entendê-la, afirma: "A posição de Babbitt é insustentável. Numa democracia permitimos qualquer um escrever o que bem entende e para quem bem quiser - ou para ninguém, se preferir. E é justamente o que muitos artistas, inclusive alguns nome famosos, preferiram fazer: criar para os especialistas no campo em que trabalham e esquecer se estão sendo aceitos ou não pelo público em geral. Disso resulta que a maioria dos romancistas, poetas, compositores, atores e pintores tidos como 'sérios' sobrevivam economicamente dos vínculos que mantêm com as escolas, universidades e outras instituições na qualidade de professores, artistas residentes, conferencistas, diretores, postos em departamentos de bolsas. Seus trabalhos são publicados em revistas de pequena circulação e apresentados nos teatros locais e nas salas de concerto das universidades. Suas platéias são principalmente formadas por estudantes universitários, professores da matéria em questão e de seus competidores. Sem o mundo acadêmico, o grosso da arte contemporânea teria desaparecido e seus criadores obrigados a procurar outra forma de trabalho." COLLIER, James Lincoln. Jazz: a autêntica música americana. Rio de Janeiro: Zahar, 1995, p. 159.
} 
música popular e o prazer indubitável que traz a incontáveis milhões de consumidores, é surpreendente que a indústria responsável pela sua produção e distribuição seja muitas vezes tratada com profunda suspeita, se não com hostilidade declarada" por aqueles que se opõem aos aspectos comerciais da produção musical. Segundo Stroud, "parte dessa reação pode ser atribuída à influência dos escritos de Theodor Adorno, que, por volta dos anos 1940, difundiu a concepção de que a música popular é o produto de uma indústria cultural que a toma como uma mercadoria como outra qualquer e a comercializa impiedosamente para um público de massa com pouca consideração para questões estéticas". Ainda conforme Stroud, "o ceticismo de Adorno foi baseado em suas observações dos efeitos das inovações tecnológicas nos meios de comunicação, tais como a introdução do fonógrafo, o rádio e o cinema falado, na Alemanha nazista (de onde fugiu em 1933) e posteriormente nos Estados Unidos, onde viveu". "Adorno concluiu que o uso da música popular como uma forma de entretenimento foi deliberadamente manipulado pela indústria da música e pelo Estado, para induzir passividade entre o público, a fim de promover a aceitação de autoritarismos e reduzir a oportunidade dos indivíduos pensarem".312

Assim, é bastante intrigante sua quase onipresença nas pesquisas sobre música popular até o final do século passado. Mesmo aqueles que dele discordavam tinham que se referir às suas formulações, mostrar que não iam por esse caminho. Era preciso acertar as contas com Adorno e, mesmo nas passagens mais críticas, fazer sempre alguma reverência. Isso não acontecia com outros pensadores de grande estatura que também abordaram temas relacionados à influência da modernidade na produção artística, como Eco, Morin, McLuhan, ou mesmo Benjamin. De fato, Adorno encontra-se entre os primeiros pensadores de peso a se ocupar da música popular como objeto de estudo. Esse é um mérito inegável. Mas ele o fez de uma perspectiva

\footnotetext{
312 STROUD, Sean. Disco é cultura: MPB and the defense of tradition in Brazilian popular music. PhD Thesis. University of London. 2005, p. 123-124. Tradução livre do autor: "Considering the vast global demand for popular music and the undoubted enjoyment that it brings to countless millions of consumers, it is striking that the industry responsible for its production and distribution is still often widely regarded with deep suspicion, if not downright hostility, by those opposed to the more manipulative and commercial aspects of the music business. Part of this reaction can be attributed to the abiding influence of the writings of Theodor Adorno, who contended in the 1940s that popular music was the product of a 'culture industry' which viewed it as a commercial product like any other, to be ruthlessly marketed to a mass audience with scant regard for aesthetic considerations. Adorno's scepticism was based on his observations of the effect of technological innovations in the media such as the introduction of the phonograph, radio, and 'talking' cinema, in Nazi Germany (from which he fled in 1933) and subsequently in the United States where he eventually settled. Adorno concluded that the use of popular music as a form of 'entertainment' was deliberately manipulated by the music industry and the state to induce passivity among the listening audience in order to promote acceptance of authoritarianism and to reduce the opportunity for individual or radical thought".
} 
muito crítica, com uma evidente má vontade e desprezo para com o objeto, e não deixa de ser um paradoxo que ele tenha sido tomado como referencial teórico privilegiado mesmo por pesquisadores que eram também aficionados da música popular.

Em relação a Walter Benjamin, seu clássico texto sobre a reprodução da obra de arte é também bastante citado, e, em alguns trabalhos, ocupa um lugar central, como em $O$ sertão nos embalos da música rural e Sinal Fechado, onde a expressão reprodutibilidade técnica encontra-se inclusive no título de um item: a música na época de sua reprodutibilidade técnica. ${ }^{313}$ o texto de Benjamin, publicado em 1936, representou uma reflexão importante acerca a produção artística das primeiras décadas do século XX e guardou atualidade por um certo período. Suas elaborações foram realizadas dentro de um determinado contexto histórico da produção artística e são pertinentes a esse momento, ainda que possam constituir-se em elementos instigantes para novas reflexões acerca da produção contemporânea, desde que pensadas a partir de uma perspectiva crítica. Como observou Rubén López Cano em artigo ironicamente intitulado El arte en la era de la reproducción mecánica de citas de Walter Benjamín, ${ }^{314}$ não vivemos na época da reprodução mecânica da arte, mas na época da produção digital da cultura, o que é muito distinto. A discussão da aura da obra de arte se colocou para um certo momento do desenvolvimento da tecnologia e sua reprodução acrítica, neste momento de tamanhas transformações tecnológicas, pode conter um forte componente de anacronismo. Sem descartar que este referencial possa contribuir para o estudo da música popular dos nossos dias, o diagnóstico de López Cano para a utilização das ideias de Benjamin na escrita acadêmica em espanhol é que, na maioria das vezes, assemelha-se mais a um tipo de ritualística que consistiria em repetir quase sempre as mesmas citações do filósofo. Além disto, merece consideração a crítica proposta por Nathalie Heinich à idéia da perda da "aura" da obra de arte ao mesmo tempo em que se dava a extensão de sua recepção para um amplo público e uma desritualização da relação com a obra. Para a autora, a argumentação proposta na reflexão criativa de Benjamin acerca dos efeitos das inovações técnicas na percepção da arte, corre o risco de ocultar que são justamente essas técnicas de reprodução a condição de existência dessa aura. Os originais ganhariam um status

\footnotetext{
313 MOBY, Alberto. Sinal Fechado. 2ª ed. Rio de Janeiro, Apicuri, 2008, p. 37.

314 LÓPEZ CANO, Rubén. El arte en la era de la reproducción mecánica de citas de Walter Benjamín. Observatorio de Prácticas Musicales Emergentes. Disponível em: <observatorio-musica.blogspot.com/2010/01/el-arte-en-la-era-dela-reproduccion.html> Acesso em: 26 jul. 2010.
} 
privilegiado através da circulação de suas imagens que a fotografia viabilizou. Para Heinich, "em vez de ressaltar o caráter socialmente construído do conceito de autenticidade, Benjamin o transformou numa característica substancial das obras". 315

Um conceito central que vai informar grande parte das elaborações das vertentes renovadas do marxismo é o de hegemonia, formulado por Antonio Gramsci. Esta elaboração parte da ideia de que a classe dominante sustentaria sua dominação alcançando um consenso junto à população, mediado por várias instituições da sociedade, com importante papel dos meios de comunicação de massa, processo no qual ficariam mistificadas e dissimuladas as relações de poder. Atuando no domínio da consciência e das representações, a hegemonia teria nas formas culturais populares importantes colaboradores na sua manutenção. ${ }^{316}$ Seria então necessário, nessa linha de raciocínio, se desenvolver uma contra-hegemonia, entendida como ação das classes trabalhadoras e intelectuais a ela ligados na construção de uma cultura em contraposição àquela das classes dominantes. 0 conceito de hegemonia foi retrabalhado e seu sentido ampliado por Raymond Williams em Marxismo $e$ Literatura. ${ }^{317}$

Um outro conceito gramsciano utilizado em diversas pesquisas é o de intelectual orgânico, em geral adaptado e flexibilizado para se pensar o papel de jornalistas, críticos, músicos, colecionadores, memorialistas e fãs que contribuíram para a afirmação de uma cultura musical nacional-popular que seria expressão de setores marginalizados da sociedade. Assim, por vezes, todo o sistema que se articulou em torno do samba no Rio de Janeiro foi pensado como a constituição de uma intelectualidade orgânica de setores populares. De fato existiu um fenômeno de organização de uma cultura em torno do samba, mas pensar isso a partir do conceito gramsciano parece um tanto distorcido.

Um dos conceitos mais frequentemente utilizados nas pesquisas sobre música popular no Brasil é o de invenção da tradição. A ideia de tradição inventada também está presente em inúmeros trabalhos da área de Artes e nos estudos sobre a cultura de um modo geral. ${ }^{318} 0$ conceito está definido por Eric Hobsbawm no artigo de introdução

\footnotetext{
315 HEINICH, Nathalie. A sociologia da arte. Bauru: UDUSC, 2008, p.35.

316 SHUKER, Roy. Vocabulário de música pop. São Paulo: Hedra, 1999.

317 WILLIANS, Raymond. Marxismo e literatura. Rio de Janeiro: Zahar, 1979.

318 Aqui mais um exemplo de ambiguidade terminológica. Ao escrever "estudos sobre a cultura" e não "estudos culturais", quis evitar passar a ideia de que me referia a uma determinada corrente, os Cultural Studies, uma vez que
} 
ao livro clássico A invenção das tradições, coletânea de artigos organizada em conjunto com Terence Ranger:

Por "tradição inventada" entende-se um conjunto de práticas, normalmente
reguladas por regras tácita ou abertamente aceitas; tais práticas, de natureza
ritual ou simbólica, visam inculcar certos valores e normas de comportamento
através da repetição, o que implica, automaticamente, uma continuidade em
relação ao passado. Aliás, sempre que possível, tenta-se estabelecer
continuidade com um passado histórico apropriado.319

Segundo Hobsbawm, o termo "é utilizado num sentido amplo", podendo incluir tanto tradições mais claramente inventadas, constituídas e institucionalizadas, como aquelas que surgem "de maneira mais difícil de localizar num período limitado e determinado de tempo - às vezes coisa de poucos anos apenas - estabelecendo-se "com enorme rapidez". ${ }^{320}$ Ora, num debate acerca de um objeto que tem pouco mais de um século de existência - a música popular urbana no Brasil - no qual a presença de "tradições" é uma constante, a utilidade desse instrumental teórico para se pensar a constituição dessas tradições, fica muito claramente colocada. Mais do que apenas as questões musicais, toda a operação de construção da identidade nacional empreendida nas décadas de 1920 e 1930, e a constituição de alguns símbolos, hoje identificados pelo senso comum como perenes e constituintes de um certo espírito nacional, pode ser analisada à luz deste conceito tão simples e objetivo, quanto criativo em sua elaboração e olhar refinado para processos históricos complexos.

Toda uma concepção do que vem a ser música popular brasileira pode ser olhada sob o prisma da ideia de tradição inventada. Uma linhagem que parte de um ramo da música popular carioca acabou se constituindo no imaginário popular como aquilo que melhor define a sonoridade do Brasil. Esta questão está analisada em $A$ síncope das idéias, de Marcos Napolitano, para quem a tradição da música popular brasileira "tem muito de 'tradição inventada', mas nem por isso está menos enraizada nos corações e mentes". Samba, bossa nova e MPB, constituiriam essa linha formativa de nossa tradição musical popular. Segundo Napolitano, "as convenções, os debates, as estéticas e as ideologias em torno desses três gêneros acabaram por legar uma tradição que, obviamente, não faz justiça à riqueza e à diversidade de todas as manifestações

nem todos os "estudos culturais" tem que seguir necessariamente as proposições teóricas dos Estudos Culturais ingleses.

319 HOBSBAWM, Eric; RANGER, T. A Invenção das tradições. Rio de Janeiro. Editora Paz e Terra, 1997, p.9.

320 Ibidem, p. 9. 
musicais do Brasil". ${ }^{321}$ Cada vez mais esta concepção vem sendo ampliada pelo campo de produção, na busca de outras informações e linguagens, bem como repensada em estudos acadêmicos sobre a história da música no Brasil. Também pode ser vista do prisma da invenção da tradição, a ideia que esteve em voga em pesquisas acadêmicas durante os anos 1970 e 1980, de que a música popular no Rio de Janeiro teria uma tradição malandra. Tiago de Melo Gomes apontou esta questão, indicando que, antes de 1927, inexistiam sambas apologéticos da malandragem. Os discursos em torno da "autenticidade", "tradição" e "raiz", frequentes atualmente em certas rodas de choro e de samba, também se inserem nesta construção. Neste aspecto, a historiografia se divide entre autores que discutem as "origens" como movimento histórico gerador dos desdobramentos posteriores e aqueles que as examinam como processo cultural descontinuo e indeterminado.

Os balanços da historiografia no século $\mathrm{XX}$, em geral, apontam que o movimento da história em direção ao social esteve marcado por dois paradigmas de explicação dominantes: o marxismo, por um lado e a escola dos Annales, por outro. ${ }^{322}$ Até o momento, o foco esteve na repercussão dos conceitos oriundos do marxismo, em distintas vertentes, nas pesquisas sobre música popular. A seguir, o foco será direcionado para formulações e conceitos apoiados na chamada Nova História, bem como no trabalho de historiadores e cientistas sociais que pensaram a história da cultura e influenciaram ou dialogaram com suas posições. Neste caso, não necessariamente como um paradigma explicativo da história ou um grupo mais restrito e coeso em termos teóricos, mas como um campo de referências fundamentais para se pensar a história da cultura, composto por nomes como Michel Foucault, Roger Chartier, Michael de Certeau, Carlo Ginzburg, na releitura dos trabalhos de Mikhail Bakhtin e na sociologia de Norbert Elias e Pierre Bourdieu. Acrescente-se que existem pontos de contato entre a Nova História Cultural francesa e os Estudos Culturais Ingleses, até mesmo pela influência que a historiografia francesa exerceu sobre os historiadores marxistas ingleses.

\footnotetext{
321 NAPOLITANO, Marcos. A síncope das idéias: a questão da tradição na música popular brasileira. São Paulo: Editora Fundação Perseu Abramo, 2007, pp.5-7.

322 HUNT, Lynn. A nova história cultural. São Paulo, Martins Fontes, 1992, p. 2.
} 
Conforme já apontado no início do capítulo, por um conjunto de razões, a Nova História tardou a adentrar na historiografia brasileira, o que só ocorreu a partir de meados da década de 1980. Assim, dentro do recorte cronológico deste estudo, podemos notar uma incidência maior destas referências mais para o final do período. Isto pode ser exemplificado no conjunto das pesquisas na área de História dentro de nossa periodização, com os estudos de José Geraldo Vinci de Moraes (Sonoridades Paulistas, 1989 e Metrópole em Sinfonia, 1997) e Wolney Honório Filho (O sertão no embalos da musica rural, 1992 e No ar amores amáveis, em 1998), que realizaram dissertação de mestrado e tese de doutorado sobre música popular no período, trabalhos que podem ser compreendidos numa linha de história da cultura. Além do natural amadurecimento e ampliação do universo de informações dos pesquisadores na continuidade de seus estudos, podemos observar nas teses de doutorado dos pesquisadores mencionados a incorporação de um referencial teórico que não estava disponível (ou era muito recente) no momento da realização de seus primeiros trabalhos. Em Metrópole em Sinfonia encontramos referências a Chartier, Certeau e Burke que não estão em Sonoridades Paulistanas, o que não seria de se esperar, por razões cronológicas. Em Sonoridades Paulistanas, uma referência importante entre historiadores é Michael Vovelle, além de referências a pensadores da cultura no Brasil, com destaque para Wisnik e a orientação de Elias Thomé Saliba. No caso de Honório Filho, observamos também na tese de doutorado a incorporação de lançamentos então recentes do mercado editorial brasileiro, bem como um trabalho mais apurado com títulos presentes na bibliografia de sua dissertação, que eram muito recentes quando da realização do trabalho. Arriscaria aqui dizer que, por vezes, certas elaborações teóricas precisam de um tempo para serem devidamente digeridas intelectualmente, não apenas no plano individual, mas especialmente no coletivo.

Creio que os trabalhos que mais claramente apontaram para uma vertente da história da cultura da música popular foram as pesquisas de Alcir Lenharo e Vinci de Moraes. Entretanto, estes autores, por questões estilísticas ou de concepção, não são pródigos em citações de referenciais teóricos, ainda que trabalhem com uma perspectiva teórica definida. Em Cantores do Rádio, ${ }^{323}$ praticamente não há citações de

323 LENHARO, Alcir. Cantores do rádio: a trajetória de Nora Ney e Jorge Goulart e o meio artístico do seu tempo. Campinas: Editora da UNICAMP, 1995. 
referenciais teóricos e a bibliografia é econômica. O livro de Lenharo, entretanto, tornou-se uma referência como modelo de pesquisa. Conceitos importantes numa visão renovada da história da cultura, como os de representação, prática, apropriação, estratégia, tática e circularidade cultural, vão aparecer em trabalhos realizados a partir de meados da década de 1990, a exemplo das pesquisas de Simone Luci Pereira, Wolney Honório Filho e José Edson Schümann Lima.

Nesta linha de pesquisa, foram muito influentes as contribuição de três autores que tiveram textos publicados em português por volta de 1990, que se constituíram em referências fundamentais: Michael de Certeau, ${ }^{324}$ Roger Chartier ${ }^{325}$ e Carlo Ginzburg. ${ }^{326}$ Em A História Cultural: entre práticas e representações, Chartier faz da noção de representação, entendida num sentido mais "particular e historicamente determinado" do que em outras acepções mais amplas nas quais o termo foi anteriormente empregado, uma pedra angular de sua abordagem. 0 conceito permitiria articular distintas "modalidades de relação com o mundo social". 327 A questão das representações do real "através das séries de discursos que o apreendem e estruturam, conduz" à questão da sua apropriação por seus receptores. A noção de apropriação tem, para Chartier, um caráter central, e visa pensar "uma história social das interpretações", observadas nas suas "determinações fundamentais" e "inscritas nas práticas específicas que as produzem". Representação, prática e apropriação, noções que já se encontravam presentes em A Invenção do Cotidiano, de Michel de Certeau, que está entre as referências de Chartier, são assim as três noções básicas nas suas proposições para a abordagem da História Cultural. Na elaboração de Chartier, a História Cultural deve ser pensada, "por um lado, como análise do trabalho de representação, isto é, das classificações e das exclusões que constituem, na sua

324 CERTEAU, Michel de. A Invenção do Cotidiano. Rio de Janeiro: Vozes, 1994. Titulo original: L'invention du quotidien, 1980.

325 CHARTIER, Roger. A História Cultural: entre práticas e representações. Algés, Portugal: Diefel Editorial, 1990.

326 GINZBURG, Carlo. O queijo e os vermes: o cotidiano e as idéias de um moleiro perseguido pela Inquisição. São Paulo: Companhia das Letras, 1987. Título original: l formaggio e i vermi. Il cosmo di un mugnaio del '500, 1976; Mitos, emblemas, sinais: morfologia e história. Companhia das Letras, 1989. Título original: Mitti emblemi spie: morfologia e storia, 1986.

327 “CHARTIER, Op. cit., p. 23. Acerca do conceito de representação, Chartier afirma que: "Mais do que o conceito de mentalidade, ele permite articular três modalidades de relação com o mundo social: em primeiro lugar, o trabalho de classificação e de delimitação que produz as configurações intelectuais múltiplas, através das quais a realidade é contraditoriamente construída pelos diferentes grupos; seguidamente, as práticas que visam fazer reconhecer uma identidade social, exibir uma maneira própria de estar no mundo, significar simbolicamente um estatuto e uma posição; por fim, as formas institucionalizadas e objetivadas graças às quais uns 'representantes' (instâncias coletivas ou pessoas singulares) marcam de forma visível e perpetuada a existência do grupo, da classe ou da comunidade." (p.23) 
diferença radical, as configurações sociais e conceptuais próprias de um tempo ou de um espaço"; por outro, "deve ser entendida como o estudo dos processos com os quais se constrói um sentido", dirigindo-se às práticas plurais e contraditórias desta construção. ${ }^{328}$

São também profícuas para se pensar a história da música popular as elaborações de Chartier acerca das delimitações de certas categorias em pares dicotômicos. Uma primeira divisão tradicional seria entre cultura letrada e popular, alta cultura e cultura popular, que, apresentada como evidente, traz consigo importantes desdobramentos metodológicos. Os textos da cultura popular seriam olhados de uma abordagem externa, sociológica, enquanto a produção da chamada alta cultura seria digna de uma abordagem interna que desvendaria sua individualidade, originalidade e complexidade. A esta dicotomia, Chartier opõe as formulações de Bakhtin e Ginzburg acerca da inter-relação entre elementos da cultura letrada e popular. Para Chartier, o questionamento do "par letrado/popular conduz" a um segundo problema, "a oposição entre criação e consumo, entre produção e recepção". Neste tópico, o autor, apoiando-se nas elaborações de Certeau, coloca em cheque a separação entre produção e consumo e o postulado de que as ideias ou as formas teriam um sentido intrínseco que seria independente de sua apropriação individual ou coletiva que constrói o seu sentido em múltiplas interpretações. ${ }^{329}$

No questionamento da concepção do erudito e do popular como planos independentes da cultura, tem destaque o conceito de circularidade cultural. José Roberto Zan se utiliza do conceito para afirmar a existência de uma circularidade entre os diversos níveis culturais no Brasil desde os tempos da Colônia. O conceito está presente também em Luci Pereira e pode ser útil para pensar as relações entre o erudito e popular no Brasil, onde as fronteiras entre esses campos são ainda mais nebulosas do que na cultura europeia para o estudo da qual o conceito de circularidade foi cunhado. Zan apresenta uma definição do conceito na qual articula o trabalho de alguns dos autores mencionados anteriormente:

0 conceito de "circularidade" aqui utilizado é formulado por cientistas sociais e historiadores especialmente a partir de Bakhtin que demonstra, através de

\footnotetext{
328 CHARTIER, Roger. A História Cultural: entre práticas e representações. Algés, Portugal: Diefel, 1990 p. 26-27. 329 Ibidem, p.58-59. A questão metodológica da abordagem dos aspectos internos (texto) ou externos (contexto) da obra de arte, assim como da existência de um sentido intrínseco no discurso musical, será discutida no Capítulo 6.
} 
seus estudos sobre a cultura popular na Idade Média, a existência de grande comunicabilidade entre as culturas de elite e popular. Nessa linha, o historiador Carlo Ginzburg formula a noção de "circularidade" entre diversos níveis culturais para demonstrar, através do estudo da biografia de um simples moleiro italiano do século XVI, como que as classes populares eventualmente incorporam e redefinem fragmentos da cultura erudita. Chartier defende a necessidade de se reconhecer o quanto as culturas erudita e popular estão interrelacionadas. Para ele, a cultura de elite constitui-se, de um modo geral, a partir da apropriação e reelaboração de elementos culturais de outros extratos sociais pelos intelectuais ligados às classes dominantes. Por outro lado, os segmentos sociais populares elaboram seus "sistemas de representação" utilizando-se muitas vezes de fragmentos da cultura erudita que são incorporados e re-significados por eles a partir de seus próprios códigos de significação. "Estes cruzamentos" - diz o autor - "não devem ser entendidos como relações de exterioridade entre dois conjuntos estabelecidos de antemão e sobrepostos (um letrado, outro popular) mas como produtos de 'ligas' culturais ou intelectuais cujos elementos se encontram tão solidamente incorporados uns aos outros como nas ligas metálicas". 330

O conceito de circularidade cultural de Ginzburg, que se relaciona com sua visão de cultura popular como “o conjunto de atitudes, crenças, códigos de comportamento próprios das classes subalternas num certo período histórico", tem sua inspiração teórica em Bakhtin, no seu livro A cultura popular na Idade Média e no Renascimento: o contexto de François Rebelais ${ }^{331}$, obra muito citada nas pesquisas, especialmente o conceito de carnavalização. Schümann Lima, por exemplo, se referencia em Bakhtin para discutir o grotesco que emerge no interior da canção tropicalista como um elemento importante do estilo. ${ }^{332}$

Na elaboração de Zan, esta proposição da existência de uma "circularidade entre os diversos níveis culturais no Brasil não implicava, no entanto, na ausência de conflitos sociais". Aos negros, na sociedade escravagista, era imposto não só o regime de trabalho escravo, mas também a cultura dos dominantes, o que estabelecia complexas relações "que iam desde a mais pura submissão até às práticas de resistência mais declaradas". Utilizando-se dos conceitos de estratégia e tática de Certeau, Zan considera que, “frente às 'estratégias' de dominação de seus senhores, os negros desenvolviam 'táticas' de sobrevivência. ${ }^{333}$

\footnotetext{
330 ZAN, José Roberto. Do fundo de quintal à vanguarda: contribuição para uma história social da música popular brasileira. Tese de doutorado em Sociologia. IFCH/UNICAMP, 1996, p. 7.

331 BAKHTIN, Mikhail. A cultura popular na Idade Média e no Renascimento: o contexto de François Rebelais. São Paulo: Hucitec. 4⿳亠丷厂 ed., 1999.

332 LIMA, José Edson Schümann. Brutalidade e jardim: as imagens da nação da tropicália. Dissertação de mestrado em História. UFRJ, p. 74.

333 ZAN, José Roberto. Do fundo de quintal à vanguarda: contribuição para uma história social da música popular brasileira. Tese de doutorado em Sociologia. IFCH/UNICAMP, 1996, p. 9.
} 
Zan apresenta a seguinte definição para os termos tática e estratégia, utilizados por Michael de Certeau:

O autor define estratégia como o cálculo ou a manipulação das relações de força pelo sujeito. É um tipo de ação através da qual o sujeito "postula um lugar suscetível de ser circunscrito como algo próprio", ou seja, como espaço a partir do qual é capaz de "gerir as relações com uma exterioridade de alvos e ameaças". A delimitação de um lugar próprio permite ao sujeito "capitalizar vantagens conquistadas" e "preparar expansões futuras"; exercer uma "prática panóptica a partir de um lugar de onde a vista transforma as forças estranhas em objetos que se podem observar e medir, controlar portanto e 'incluir' na sua visão" e fazer uso do poder de um saber particular que "sustenta e determina o poder de conquistar para si um lugar próprio." Por tática, o autor considera todo tipo de ação calculada, astuta, empreendida pelo sujeito em contextos em que o controle das regras é prerrogativa dos outros. Desse modo, ela joga "com o terreno que lhe é imposto tal como o organiza a lei de uma força estranha." Certeau aponta como exemplo limite desse tipo de conduta a postura das etnias indígenas diante das imposições do colonizador que muitas vezes, "usavam as leis, as práticas ou as representações que lhes eram impostas pela força ou pela sedução, para outros fins que não os dos conquistadores. 334

Até aqui estiveram em foco conceitos localizados nos trabalhos de Chartier, de Certeau e Ginzburg, que compõem uma linhagem de interpretação histórica que enfatiza a ação dos sujeitos frente às estruturas sociais. Uma outra linha interpretativa pode ser localizada na sociologia de Norbert Elias e Pierre Bourdieu, que apontam para os contrangimentos impostos pelas estruturas em relação às práticas dos agentes sociais.

Norbert Elias (1897-1990) teve um reconhecimento tardio: suas obras foram redescobertas e se tornaram influentes durante a década de 1970. No Brasil, seus trabalhos foram editados a partir dos anos 1990. No caso de Bourdieu (1930-2002), em que pese o autor já estivesse consagrado em seu país, e no plano internacional, como um dos grandes pensadores da segunda metade do século XX, sua obra vai repercutir no Brasil a partir da publicação de A economia das trocas simbólicas,335 em 1974; mas outros textos demorariam mais para serem publicados no Brasil: um de seus escritos fundamentais, A distinção: crítica social do julgamento,336 somente teve sua tradução publicada em 2007. Embora seja esperado que os pesquisadores leiam em língua estrangeira, é natural que a influência destas obras nos círculos acadêmicos brasileiros

\footnotetext{
334 Ibidem, p.10.

335 BOURDIEU, Pierre. A Economia das trocas simbólicas. Introdução, organização e seleção de Sérgio Miceli. 5a ed. São Paulo: Perspectiva, 2004. Primeira edição de 1974.

336 Idem. A Distinção: crítica social do julgamento. São Paulo: Edusp; Porto Alegre: Zouk, 2007. Titulo original: La distinction: critique sociale du jugement, 1979.
} 
tenha aumentado em função de uma maior circulação de seus trabalhos em língua portuguesa.

$\mathrm{Na}$ sociologia de Pierre Bourdieu, o conceito de campo tem um lugar de destaque. Campos, para Bourdieu, são espaços sociais estruturados de relações entre agentes em "luta concorrencial" pela "distribuição do capital específico". 0 autor chama de capital específico aquele que "vale em relação a um certo campo', dentro dos limites deste, não sendo automaticamente conversível em outras espécies de capital, por exemplo, em capital financeiro, ou em capital simbólico específico de outros campos. Um campo se caracteriza, "entre outras coisas através da definição dos objetos de disputas e dos interesses específicos que são irredutíveis aos objetos de disputas e interesses próprios de outros campos". Esses objetos e interesses somente são percebidos claramente por quem foi formado para entrar no campo em questão, pessoas que possuem um habitus, um conhecimento das regras e disposições específicas desse espaço social. Uma categoria de interesses específicos de um campo implica em distinções com outros interesses e investimentos, podendo assim ser apreendidos de maneira distorcida, como atos absurdos, irrelevantes ou desinteressados, por exemplo, por quem não tenha o habitus correspondente. $\mathrm{Na}$ sociologia de Bourdieu, habitus são estruturas "de disposições adquiridas pela aprendizagem implícita ou explícita"337 que funcionam como "princípios geradores de práticas distintas e distintivas": implicam no conhecimento e reconhecimento das "regras do jogo". "Os habitus são diferenciados, mas são também diferenciadores" em relação a outras estruturas. ${ }^{338}$ Bourdieu descreve a constituição progressiva de campos específicos de produção intelectual e artística, com uma relativa autonomização do sistema de produção, circulação e consumo dos bens simbólicos em relação a todas as instâncias com pretensões a legislar na esfera cultural.

Para Bourdieu, esta luta concorrencial por posições no interior de um campo se dá num contexto de um acordo entre os agentes em luta, que diz respeito à própria existência e manutenção do campo. Existe uma cumplicidade entre os antagonistas em relação aos objetos de disputa e às regras do jogo, "aceitos pelo fato de entrar no jogo".

\footnotetext{
337 Idem. Algumas propriedades dos campos. In: Questões de sociologia. Rio de Janeiro: Marco Zero, 1983b, pp. 89-90 e 94 .

338 BOURDIEU, Pierre. Razões Práticas: sobre a teoria da ação. Tradução de Mariza Corrêa. 4ª ed. Campinas, SP: Papirus, 1996, p. 22.
} 
Os envolvidos na disputa contribuem para "a reprodução do jogo", para a percepção do valor do que está em jogo e tem em comum o interesse no aumento deste valor. 339

Pensando nas sociedades europeias e mais especificamente na França, Bourdieu descreve o processo de constituição progressiva, nas sociedades modernas, de campos específicos "de produção intelectual e artística" e sua relativa autonomização em relação às instâncias tradicionais de legitimação. No que se refere ao campo da produção intelectual e artística, o sociólogo francês vê a oposição entre um campo de produção erudita, auto-referenciado, e um campo de produção de bens simbólicos constituído em estreita relação com o mercado.

O sistema de produção e circulação de bens simbólicos defini-se como o sistema de relações objetivas entre diferentes instâncias definidas pela função que cumprem na divisão do trabalho de produção, de reprodução e de difusão de bens simbólicos. O campo de produção propriamente dito deriva sua estrutura específica da oposição - mais ou menos marcada conforme as esferas da vida intelectual e artística - que se estabelece entre, por um lado, $o$ campo de produção erudita enquanto sistema que produz bens culturais (e os instrumentos de apropriação desses bens) objetivamente destinados (ao menos a curto prazo) a um público de produtores de bens culturais que também produzem para produtores de bens culturais; e, de outro lado, $o$ campo da indústria cultural, especificamente organizado com vista à produção de bens culturais destinados a não-produtores de bens culturais ("o grande público"), que podem ser recrutados tanto nas frações não intelectuais das classes dominantes ("o publico cultivado"), como nas demais classes sociais. ${ }^{340}$

No âmbito da música, "o mesmo dualismo assume", segundo Bourdieu, "a forma de um verdadeiro cisma" "entre o mercado artificialmente sustentado e quase que totalmente fechado sobre si mesmo das obras de pesquisa erudita e o mercado das obras comerciais", nas suas variadas formas. Esta dicotomia "entre os dois modos de produção de bens simbólicos" deve ser entendida como uma construção teórica limite, sem descartar as intersecções entre eles e o fato de que convivem no mesmo sistema de circulação de bens simbólicos. ${ }^{341}$

Diversos pesquisadores da música popular têm se utilizado do conceito de campo em suas discussões. Entre estes, José Roberto Zan, que apresenta os conceitos de campo e habitus como um dos referenciais teóricos de sua tese de doutorado; Enor Paiano, que em Berimbau e o som universal sustenta a idéia de que os músicos

\footnotetext{
339 Idem. Algumas propriedades dos campos. In: Questões de sociologia. Rio de Janeiro: Marco Zero, 1983b. p. 91. 340 Idem. A Economia das trocas simbólicas. Introdução, organização e seleção de Sérgio Miceli. 5a ed. São Paulo: Perspectiva, 2004, p. 105.

341 Ibidem. P. 139.
} 
populares no Brasil estiveram longamente envolvidos com um processo de legitimação de sua atividade, que no entanto só se concretizou como um campo nos anos 1960; Laerte Fernandes de Oliveira em sua dissertação de mestrado em Ciências Sociais intitulada Em um porão de São Paulo: o Lira Paulistana e a produção alternativa, PUCSP, 1999, destaca o conceito de campo como um dos referenciais básicos utilizados em seu trabalho.

É possível identificar que, a partir de meados dos anos 1990, se incorpora, de uma maneira mais generalizada, nas pesquisas sobre música popular, um corpo teórico mais atualizado, que expressa o desenvolvimento e o estado do conhecimento nos estudos dos fenômenos culturais. Entre as principais tendências, encontram-se a vertente historiográfica representada pelos trabalhos de Michael de Certeau, Roger Chartier e Carlo Ginzburg, a sociologia de Norbert Elias e Pierre Bourdieu, e os estudos culturais ingleses, a exemplo dos trabalhos de Raymond Williams. É importante destacar que, a partir de por volta de 1990, temos uma maior circulação no país de obras destes autores que foram editadas em português. Durante a década de 1990, ocorre a edição nacional de obras de estudiosos da cultura latino-americana como Jesús Martín-Barbero e Néstor Garcia Canclini, que irão ter uma incidência expressiva em trabalhos mais recentes.

Em relação a alguns dos autores mencionados - Pierre Bourdieu, Roger Chartier e Michel de Certeau - é preciso sempre ter em mente que seus estudos sobre arte, leitura ou cultura foram feitos a partir da análise das sociedades europeias, tendo em vista especialmente o caso francês. Suas teorizações e conceitos foram elaborados para a análise desse contexto sociocultural. Assim, sua aplicação para as circunstâncias da sociedade e da história brasileiras e, mais especificamente, para a história da música popular no Brasil, precisa sempre passar por uma reflexão crítica e certas adaptações. Mais recentemente, estudiosos da cultura latino-americana vêm sendo tomados como referencial privilegiado. Entre os livros mais influentes e citados em pesquisas mais recentes, encontram-se Dos meios às mediações: comunicação, cultura e hegemonia, ${ }^{342}$ do autor espanhol radicado na Colômbia, Jesús Martín-Barbero, de 1987, publicado no

342 MARTÍN-BARBERO, Jesús. Dos meios às mediações: comunicação, cultura e hegemonia. Rio de Janeiro: Editora UFRJ, 1997. Primeira edição espanhola, 1987. 
Brasil em 1997, e Culturas híbridas: estratégias para entrar e sair da modernidade, ${ }^{343}$ do autor argentino Néstor Garcia Canclini, de 1989 e publicado no Brasil em 1997.

Por outro lado, estudos de intelectuais brasileiros acerca dos fenômenos da cultura no Brasil se apresenta como instrumental teórico privilegiado para se pensar a história da música popular. Entre estes, destaca-se Antonio Candido. Embora não tenha se ocupado diretamente da música popular, seus trabalhos inspiraram pesquisadores de diversas áreas, a aplicar suas elaborações sobre a cultura e a literatura nacional nos estudos musicais populares. José Miguel Wisnik talvez seja o intelectual que melhor incorporou as proposições de Antonio Candido num esforço de pensar a música no Brasil. Seus estudos também são uma referência importante nas pesquisas, assim como os trabalhos de Arnaldo Contier, que constituíram fundamentos para a historiografia acadêmica, conforme apontado no Capítulo 2. Não abordaremos seus trabalhos neste item, posto que já foram comentados anteriormente. Também Renato Ortiz é um autor bastante citado em diversos estudos, ainda que sua localização do momento de consolidação do mercado cultural no Brasil tenha sido objeto de polêmica em algumas pesquisas. Marilena Chauí é mencionada em diversos trabalhos, especialmente para a discussão do nacional e do popular na cultura brasileira. Outro autor muito citado é Roberto DaMatta, já mencionado como referência de algumas das pesquisa pioneiras.

É interessante observar que a forte pesquisa sobre música popular produzida no mundo anglo-saxão a partir dos anos 1980, trabalhos produzidos na Europa e Estados Unidos, demoraram para repercutir nas pesquisas brasileiras, e sua influência se situa praticamente fora da periodização deste trabalho. É certo que os trabalhos de história partiam de outros objetos e circunstâncias. Mas trabalhos teóricos mais gerais e estudos sociológicos da música popular poderiam ter sido incorporados anteriormente, a exemplo dos textos de Richard Middleton, ${ }^{344}$ Simon Frith, Phillip Tagg, ${ }^{345}$ Keith Negus, ${ }^{346}$ Franco Fabbri, ${ }^{347}$ entre outros autores. Da mesma forma, a

\footnotetext{
343 CANCLINI, Néstor Garcia. Culturas híbridas. Estratégias para entrar e sair da modernidade. São Paulo: EDUSP, 1997. Primeira edição em espanhol, 1989.

344 MIDDLETON, Richard. Studying Popular Music. Great Britain: Open University Press, 1990.

345 Philip Tagg tem uma vasta produção bibliográfica, na qual se incluem artigos como Analysing popular music (Popular Music no 2, p.37-67, 1982) ou livros como Ten little title tunes: Towards a musicology of the mass media (New York \& Montreal: The Mass Media Music Scholars' Press, 2003) escrito em conjunto com Bob Clarida. Sua bibliografia encontra-se em sua página na Internet, disponível para download gratuito ou, no caso dos livros, mediante uma pequena contribuição para a manutenção do site. Disponível em: <www.tagg.org>. Acesso em: 13 out. 2010.
} 
agenda de estudos proposta pelos estudos da música popular no hemisfério norte, onde se destacam questões como juventude, gênero, subculturas urbanas e identidade, não teve maior repercussão. Estes temas vão aparecer mais para o final do período, nos estudos sobre a jovem guarda e o rock no Brasil, passando pela tropicália, mas sem que a discussão que se realizava no mundo anglófono tenha informado estes estudos.

\footnotetext{
346 NEGUS, Keith. Popular Music in Theory: an introduction. Hanover: Wesleyan University Press, 1996. 347 FABBRI, Franco. A theory of musical genres: two applications. In: Popular Music Perspectives 2, p.501-507, HORN and TAGG (eds.). Göteborg and Exeter, 1985.
} 


\section{CAPÍTULO 5 \\ A MÚSICA NA HISTORIOGRAFIA}

Neste capítulo, serão abordados dois aspectos que dizem respeito ao trato com as fontes na historiografia da música popular. No primeiro item, será observada a utilização da partitura e do fonograma como fontes na pesquisa histórica. Inicialmente, como subsídio para a reflexão, serão feitas algumas considerações conceituais sobre os suportes para a composição e circulação da música, sendo a notação em pentagrama e a gravação as principais, mas não as únicas. A seguir, será feita uma análise da utilização da partitura e do fonograma nas pesquisas historiográficas, a partir de uma revisão de sua presença nos trabalhos em estudo. Um segundo tópico está dedicado a alguns aspectos da seleção da documentação na escrita da história em torno da música popular e sua repercussão na construção da memória. A questão central em foco, nesta parte, é o fato de o material musical em estudo nas pesquisas dentro do recorte cronológico, em sua grande maioria, ter se situado em torno de um repertório canônico da música popular no Brasil, com o esquecimento de outras sonoridades.

\subsection{A PARTITURA, O FONOGRAMA E DEMAIS SUPORTES PARA A MÚSICA: SUAS UTILIZAÇÕES COMO FONTE NA HISTORIOGRAFIA.}

A partitura foi o suporte principal para o registro da música ocidental até o início do século XX. ${ }^{348}$ Antes do surgimento da gravação mecânica, a partitura foi também o suporte para a moderna música popular urbana, em gestação. Assim, os choros, maxixes, lundus-canção, tangos brasileiros, modinhas, marchas e valsas do final do século XIX eram escritos em partitura e publicados. Nos Estados Unidos, as canções

\footnotetext{
3480 momento e o local exato do surgimento da notação musical ocidental não é conhecido, mas não há evidências de tenha existido antes da Era Carolíngia, quando interesses de unificação política e religiosa do reino aceleraram a elaboração de formas de registro da música litúrgica conhecida como cantochão ou canto gregoriano. Este sistema passou por várias transformações, das primeiras formas, por volta do século IX, até meados do século XVII, quando já estava constituído, em linhas gerais, tal como o conhecemos hoje. Para uma breve história da notação ver o verbete Notation (item History of Western notation) no Groove Dictionary of Music and Musicians (OXFORD MUSIC ONLINE). Para uma análise da importância da partitura como suporte na música artística ocidental e a mudança de suporte ao longo do século XX, ver ZAMPRONHA, Edson. Notação, representação e composição: um novo paradigma da escritura musical. São Paulo: Annablume/FAPESP, 2000.
} 
de Tin Pan Alley ${ }^{349}$ circularam através da partitura e as editoras compuseram um importante pólo de articulação do mercado de bens culturais. Para uma história desta produção, a partitura é a fonte primária primordial. As práticas musicais e sonoridades urbanas que não foram documentadas em partitura antes do surgimento do registro sonoro, e mesmo depois dele, num estágio do desenvolvimento tecnológico em que o acesso à gravação ainda não estava democratizado, foram perdidas irremediavelmente. Não por acaso, são geralmente musicólogos ou historiadores com formação musical que se dedicam ao estudo deste período. Um exemplo de fonte documental importante para o estudo musicológico da gênese dos gêneros de música popular no Brasil são os manuscritos anônimos 1595 e 1596 da Biblioteca da Ajuda, em Lisboa, Portugal. Estes textos foram descobertos por Gerard Béhague e revelados no artigo Biblioteca da Ajuda (Lisbon) Mss 1595/1596: two Eightenth-Century anonymous collections of modinhas, de 1968. 350 O manuscrito 1596, intitulado Modinhas do Brazil, compostos de 30 modinhas e lundus escritos no final do século XVIII, para dois sopranos e baixo contínuo, foi publicado em As Modinhas do Brasil, de Edilson de Lima, cuidadosa e muito bem acabada edição fac-similada e comentada, que vem acompanhada de um CD com a gravação do material. ${ }^{351}$

Mas a partir do advento das técnicas de registro e reprodução do material sonoro e sua popularização nas primeiras décadas do século XX, o suporte privilegiado para o registro da música popular urbana passou a ser a gravação. Ou, vendo a questão por outro ângulo, as modernas tecnologias tiveram um impacto decisivo no desenvolvimento da música popular, no mundo todo, e no Brasil, particularmente. Pode-se dizer que a gravação teve para a produção musical no século XX importância comparável àquela que teve a notação na história da música ocidental até o advento do fonograma.

\footnotetext{
349 Tin Pan Alley é como era chamado o conjunto dos editores de partituras de Nova York que dominaram o mercado da música popular americana no final do século XIX e começo do século XX. Por extensão, a expressão passou a ser associada como sinônimo da emergente canção popular dos Estados Unidos. Uma hipótese para o apelido é que ele sugeria com "panelas" o som metálico dos velhos pianos verticais e o "beco" seria o local onde originalmente estavam sediadas essas editoras. 0 centro equivalente de Tin Pan Alley em Londres foi Denmark Street e conjuntamente estes centros dominaram o mercado internacional até por volta de 1930.

350 BÉHAGUE, Gerard. Biblioteca da Ajuda (Lisbon) Mss 1595 / 1596: two Eighteenth-Century anonymous collections of modinhas. Texas: University of Texas Press. Anuario, Vol. 4, 1968, pp. 44-81.

351 LIMA, Edilson de. As Modinhas do Brasil. São Paulo, EDUSP, 2001. O estudo é fruto da pesquisa de mestrado As "Modinhas do Brasil" da Biblioteca da Ajuda, Lisboa, Instituto de Artes da UNESP, 1998.
} 
Segundo um certo senso comum, a partitura é vista como a notação codificada de procedimentos musicais, frequências sonoras, tratamento rítmico e indicações de instrumentação e performance, que podem ser decodificados e reproduzidos por aqueles que dominam o código. Nesta visão, a partitura seria um suporte para registro e veiculação de ideias musicais; não seria a música, mas sua codificação num sistema simbólico, um meio de registro para ser realizado na execução musical. Conforme aponta Edson Zampronha, nesta concepção, a notação ideal seria aquela "capaz de registrar e comunicar a informação musical o mais exatamente possível”. 0 compositor codificaria a música num sistema simbólico ancorado num conjunto de regras e um interprete conhecedor deste sistema seria capaz de decodificar a notação e restituir a informação sonora original. Ou seja, primeiro viriam as ideias musicais e depois sua escritura em partitura. 0 sistema de notação teria se aperfeiçoado ao longo do tempo conforme novas exigências foram se impondo pelo desenvolvimento das formas de estruturação do material musical. ${ }^{352}$

Entretanto, a relação entre notação e produção musical é mais complexa. Na história da música ocidental, o desenvolvimento do sistema de notação foi abrindo novas possibilidades para a criação sonora ao mesmo tempo em que o desenvolvimento da estruturação musical implicava novos desafios para a escritura. Assim, a história da música no Ocidente é indissociável da elaboração do sistema de notação. Max Weber explicou o surgimento da polifonia, da tonalidade e dos modernos sistemas musicais ocidentais a partir da invenção da notação musical, que ele considerou ainda mais importante para a existência dessa música do que a escrita fonética para a existência das formas artísticas linguísticas. ${ }^{353}$

Embora as vanguardas musicais no século XX tenham criado novas formas de notação musical, o repertório tradicional e canônico da música artística ocidental ainda está registrado em notação tradicional no pentagrama. Este sistema de notação está diretamente relacionado a uma certa concepção de música e um certo repertório. Como apontou Richard Middleton, esse sistema privilegia determinados parâmetros mais facilmente passíveis de serem notados: frequências sonoras discretas dentro da escala

352 ZAMPRONHA, Edson. Notação, representação e composição: um novo paradigma da escritura musical. São Paulo: Annablume/FAPESP, 2000, p. 21-27.

353 WEBER, Max. Fundamentos racionais e sociológicos da música. São Paulo: EDUSP, 1995, p. 119-123. 
cromática (notas), combinações delas (acordes) ou de partes melódicas usando essas frequências (contraponto), relações matemáticas simples de duração (ritmos), estruturação formal da obra, textura, orquestração e indicações de andamento e dinâmica. Por outro lado, tendem a negligenciar ou ter dificuldade com parâmetros que não são facilmente notados, tais como: frequências não padronizadas ou movimentos não discretos (slides, blue-notes, microtons e outros); nuanças rítmicas e ritmos irregulares, nuanças de ornamentação e interpretação, articulação (ataque, sustain, decay, o chamado "envelope"), além de efeitos como overdrive, wah-wah, phase e reverber, entre outros. Ou seja, apresenta grandes restrições para notação de parcela significativa da produção musical do século XX e XXI. ${ }^{354}$

Mesmo considerando-se que a gravação tornou-se o suporte fundamental para a música popular urbana, a partitura desempenhou e ainda desempenha papel importante para parte significativa do repertório. No caso específico da música brasileira, podemos mencionar as obra de fundadores como Chiquinha Gonzaga, Ernesto Nazareth e Anacleto de Medeiros, o repertório "clássico" do choro, os arranjos para orquestra (desde a Era do Rádio, passando pela bossa nova, até nossos dias) e a produção contemporânea de música popular instrumental, para pequenas e grandes formações, que vem apresentando vigor renovado e crescimento de público. Uma parte da música composta para violão solo cujo suporte foi a gravação vem sendo transcrita em partitura, como os trabalhos de Garoto e Baden Powell. Algumas peças de Garoto, como Lamentos do Morro e Jorge do Fusa entraram definitivamente para o repertório de concerto do violão após a publicação das transcrições realizadas por Paulo Bellinati. ${ }^{355}$ Devemos considerar também o aumento da oferta de partituras de música

\footnotetext{
354 MIDDLETON, Richard. Studying Popular Music. Great Britain: Open University Press, 1990, pp. 104-105. 355 BELLINATI, Paulo. The guitar works of Garoto (Annibal Augusto Sardinha). 2 vols. San Francisco, USA: Guitar Solo Publications. Algumas peças de Garoto já haviam sido transcritas e publicadas anteriormente por Geraldo Ribeiro, mas o trabalho de Paulo Bellinati alcançou maior repercussão e consolidou no repertório erudito temas como Lamentos do Moro, Jorge do Fusa e outros como Desvairada, Improvisos e Sinal dos Tempos. Sobre este tema, Maurício Orosco, violonista e professor da UFU, observou-me, em conversa por e-mail, que o violão no Brasil sempre teve este caráter híbrido e que podemos falar de gerações pioneiras que publicaram seus trabalhos, senão diretamente, por intermédio de um revisor violonista. Estas gerações abrangem nomes relativamente desconhecidos como Atílio Bernardini, Levino Albano da Conceição (professor do Dilermando Reis), Mozart Bicalho e nomes já difundidos como João Pernambuco, o próprio Dilermando Reis e os considerados precursores irmãos Américo e Antônio Jacomino. Segundo Orosco, é dentro desta linha paralela, de violão híbrido, por assim dizer, com estilo brasileiro mas com "técnica européia" - entendendo pelo termo a acomodação do discurso em texturas cuja melodia alcança certa independência em relação ao acompanhamento, por meio do processo contínuo de inversão de acordes que permite à melodia o deslocamento em todos os registros do braço do instrumento, além da presença constante de figuras ornamentais de ligação entre seções - que futuramente vai se enquadrar a figura do Garoto, cujo trabalho acrescentará tensões harmônicas ao discurso, bem como tratamento técnico-violonístico mais rebuscado em si, além de acrescido de procedimentos técnicos advindos do jazz (ex.: uso do dedo 4 da mão esquerda para pressionar duas
} 
popular na forma de melodias cifradas no país a partir da publicação dos Songbooks editados de Almir Chediak. Este é um evento extremamente positivo para músicos profissionais e amadores ao facilitar o acesso ao material musical. Entretanto, esse fato tem alguns aspectos que precisam ser observados. Por um lado, contribuíram para a formação de um cânone de obras a partir da seleção do editor. Por outro, é preciso lembrar que a partitura (em geral melodia cifrada, no caso da canção popular e dos real books do jazz) constitui apenas um mapa de parâmetros estruturais fundamentais de determinada obra, muitas vezes a partir de uma transcrição musical, que pode inclusive conter imprecisões. Como observou Napolitano, "a partitura é apenas um mapa, um guia para a experiência musical significativa, proporcionada pela interpretação e pela audição da obra". Tomar a partitura pela obra "seria o mesmo equívoco de olhar um mapa qualquer e pensar que já se conhece o lugar nele representado". 356

Mas o suporte fundamental para o desenvolvimento da música popular urbana, tal como a conhecemos hoje, foi o fonograma. A música popular desenvolveu-se conjuntamente com a evolução das técnicas de gravação. A gravação permitiu o registro da produção de músicos não familiarizados com a escrita musical bem como a produção em estúdio de obras que não seriam sequer pensadas sem a concorrência das modernas técnicas de gravação. Um exemplo disto é o fato dos Beatles terem parado de se apresentar ao vivo para se tornarem músicos de estúdio, condição em que produziram obras inovadoras e influentes com o aclamado LP Sgt. Pepper's Lonely Hearts Club Band.

Luiz Tatit considera que a aliança dos "músicos populares com a tecnologia nascente é crucial para se compreender a inversão de expectativas que mudou o destino da música no Brasil". O autor avalia que "o encontro dos sambistas com o

cordas, si e mi, na segunda parte de Sinal dos Tempos) . Um caso curioso nesta tradição é o de Baden Powell, que não foi adotado pelos violonistas e público erudito como um compositor desta vertente híbrida, mas percebido como um violonista popular, apesar de sua técnica reconhecidamente exuberante. Sobre Baden, a hipótese de Maurício Orosco é a de que o caráter fortemente improvisatório de suas gravações colocou-o num plano em que já não se pode mais considerá-lo dentro da tradição escrita; não é mais uma música que nasce no papel, ou próxima a ele como concepção composicional, mas nasce totalmente na prática. Improvisos, o Garoto também fazia, mas no seu caso, a composição final estava menos associada ao improviso de maneira geral, e mais alinhada à idéia de registro de modo geral. No caso do estilo violonístico de Baden, as peças que interpretava, suas ou de outros autores, poderiam ser muito diferentes a cada versão. As transcrição de suas gravações para partitura são apenas o registro de uma certa versão. Seu estilo pertenceria, portanto, a outro universo do que aquele dos hibridismos incorporados ao universo da música de concerto. OROSCO, Maurício. [Mensagem eletrônica pessoal ao autor]. Recebida em: 17 out. 2010.

356 NAPOLITANO, Marcos. História \& música: história cultural da música popular. Belo Horizonte, Autêntica, 2002, p. 84. 
gramofone mudou a história da música brasileira e deu início ao que conhecemos hoje como canção popular". A ideia do autor é que os músicos da "tradição escrita", compreendendo aí a música erudita, setores do choro e da modinha, "não sofriam especialmente com a impossibilidade de registro sonoro", uma vez que "suas peças estavam na partitura e eram executadas ao vivo". Mas a gravação permitiu o registro da música que vinha sendo realizada por músicos sem formação escolar, musical ou literária, que retiravam suas melodias e versos da fala cotidiana, agregando outras informações sonoras em suas práticas orais. Sem o registro, essa criação musical teria se perdido, como ocorreu com lundus e maxixes no século XIX e práticas urbanas que não se encontravam nos centros dos circuitos de gravação e difusão. ${ }^{357}$

Embora até aqui estas observações sobre o suporte para a música estejam centradas nos registros em partitura e fonograma, existem outras possibilidades: para o que interessa no nosso assunto, “a memória, os hábitos de pensamento musical (sejam individuais ou coletivos) e a gestualidade do músico". "O suporte último de representação musical é o próprio corpo do músico, seus gestos, sua mão, seu sistema neuromotor, que grava certos modos de proceder com seu instrumento ou sua voz". 358 Mas estas práticas musicais baseadas nestes suportes são as que apresentam maior dificuldade para reconstituição histórica. Como demonstrou Carlos Drehmer ${ }^{359}$, durante os anos 1950 e 1960 em Salvador, os violonistas de práticas musicais populares e informais que não sabiam ler partituras, que aliás tampouco eram disponíveis na diversidade de gêneros e repertório necessário para a prática profissional, aprendiam a tocar as músicas de sucesso no Rio de Janeiro a partir das ondas do rádio. Essa habilidade em "tirar a música de ouvido" fazia parte do modo de aprendizado e da prática musical desses instrumentistas, apoiada numa tradição oral, tato-visual e auditiva. Quando os cantores do rádio carioca se apresentavam em Salvador, não viajavam com seus acompanhantes, o que diminuía os custos de produção, pois os músicos locais estavam preparados para acompanhá-los, sem muito ensaio, reproduzindo os arranjos originais. E assim em outras cidades. Alguns destes músicos, solistas de violão, eram também compositores, mas o suporte

357 TATIT, Luiz. O século da canção. Cotia: Ateliê Editorial, 2004, pp. 34-35.

358 ZAMPRONHA, Edson. Notação, representação e composição: um novo paradigma da escritura musical. São Paulo: Annablume/FAPESP, 2000, p. 117.

359 DREHMER, Carlos Edmundo Chenaud. Violão, violonistas e memória social nas décadas de 50 e 60 em Salvador. Dissertação de mestrado em História. São Paulo: PUC-SP, 1999. 
de suas composições era sua memória e gestualidade. Essas composições, ao não serem transcritas para partituras ou gravadas, perderam-se no esquecimento. É o caso de Antônio Alves da Silva (Mestre Antônio), um dos precursores dos grupos de choro na Bahia, que entrevistado aos 80 anos de idade, afirmou não se lembrar mais como tocar suas composições, que outros instrumentistas contemporâneos afirmaram ser de boa qualidade e elevado grau de dificuldade técnica.

Se o registro sonoro contribuiu decisivamente para formatar a canção popular e o desenvolvimento da tecnologia acompanhou o desenvolvimento das formas musicais populares, sua circulação e recepção estiveram mediadas por todo um circuito cultural, conforme apontado em diversas pesquisas, com destaque para o papel dos meios de comunicação de massa. ${ }^{360}$ Dito de outra forma, o fonograma foi o suporte fundamental da música popular e influiu decisivamente nos seus rumos em conjunção com o mercado e em articulação com o seu público através de um conjunto de mediadores. A questão da recepção é um dos desafios da historiografia da música no sentido de apreender a circulação, "usos e apropriações (Certeau, 2003)" do material musical em distintos contextos histórico-sociais, na medida em que o objeto se encontra distante no tempo, "construído a partir de uma diacronia que implica na impossibilidade de 'reconstituir' ou mapear a experiência cultural dos agentes que tomaram parte no processo estudado". ${ }^{361}$

Entre as pesquisas que formaram o corpo documental de meu estudo e aqueles trabalhos que apontei como referências fundamentais para a pesquisa historiográfica, encontramos referências ao texto escrito em partitura naqueles trabalhos que tinham por objeto a música erudita ${ }^{362}$ ou a música instrumental ${ }^{363}$ e a formação dos gêneros

\footnotetext{
360 Entre outros trabalhos esta questão encontra-se em: PAIANO, Enor. Berimbau e o som universal: lutas culturais e indústria fonográfica nos anos 60. Dissertação de mestrado em Comunicação. São Paulo: ECA-USP, 1994; NAPOLITANO, Marcos. Seguindo a canção: engajamento político e indústria cultural na trajetória da música popular brasileira (1959-1969). Tese de doutorado em História. São Paulo: FFLCH-USP, 1999; STROUD, Sean. Disco é cultura: $M P B$ and the defense of tradition in Brazilian popular music. Tese de PhD. University of London. 2005; ZAN, José Roberto. Do fundo de quintal à vanguarda: contribuição para uma história social da música popular brasileira. Tese de doutorado em Sociologia. Campinas: IFCH/UNICAMP, 1996.

361 NAPOLITANO, Marcos. História \& música: história cultural da música popular. Belo Horizonte, Autêntica, 2002, p.81.

362 WISNIK, José Miguel. A música em torno da Semana de Arte Moderna. Dissertação de mestrado em Letras. São Paulo: FFLCH-USP, 1974; CONTIER, Arnaldo Daraya. Brasil Novo: música, nação e modernidade. Os anos 20 e 30. Tese de livre docência. São Paulo: FFLCH-USP, 1988; ZERON, Carlos Alberto de Moura Ribeiro. Fundamentos histórico-políticos da música nova e da música engajada no Brasil a partir de 1962: o salto do tigre de papel. Tese de doutorado. São Paulo: FFLCH-USP, 1991.

363 ESTEPHAN, Sérgio. $O$ violão instrumental brasileiro: 1884-1924. Dissertação de mestrado em História. São Paulo: PUC-SP, 1999.
} 
de música popular no final do século XIX e início do XX. ${ }^{364}$ Vinci de Moraes apresenta, no anexo de Metrópole em Sinfonia, partituras de canções mencionadas na tese, assim como João Ernani Furtado Filho em, 0 combate ao samba e o samba de combate, inclui as partituras de Meu Brasil, Brasil Novo (Villa-Lobos) e Sabemos Lutar (Nássara e Frazão), mas estes autores não enveredam por análise desses textos musicais.

Em O Coro dos Contrários ${ }^{365}$, José Miguel Wisnik analisa o texto das peças de Villa-Lobos apresentadas na Semana de Arte Moderna de 1922, para precisar as características apontadas nessas obras, as únicas de um autor brasileiro presentes na programação musical do evento e, portanto, fundamentais para situar a música em torno da Semana. Nessa discussão, o autor apresenta uma comparação crítica da análise das obras com a repercussão das mesmas entre críticos e literatos, posto que seu trabalho investiga a existência de uma interdependência entre literatura e música. Como o trabalho foi realizado na área de Teoria Literária, Wisnik faz uma explanação sucinta do sistema tonal, noção fundamental para se entender as tensões no campo musical no plano internacional, num momento de desagregação da tonalidade e propostas de renovações estéticas baseadas na estruturação da linguagem musical em torno do atonalismo. Essa digressão sobre a tonalidade pressupõe que o trabalho está dirigido a um público mais amplo do que aquele versado em teoria musical, e esse texto iniciou as reflexões acerca das interseções entre música e literatura que estão no centro dos trabalhos de Wisnik. Numa pesquisa apresentada na área de Música, esta explanação seria completamente dispensável e inclusive extemporânea numa dissertação de mestrado, posto que a noção de tonalidade encontra-se entre os rudimentos da formação técnica na disciplina. Também Arnaldo Contier, em Brasil Novo: música, nação e modernidade, recorre à análise do texto musical em seu Capítulo 5. Da mesma forma, o autor sente a necessidade, para maior clareza de sua exposição, de uma explanação sobre a tonalidade e o momento de sua desagregação. ${ }^{366}$ Embora estes autores tenham conseguido sintetizar os fundamentos do sistema tonal em linguagem verbal dirigida para não iniciados em teoria musical, ao menos ao ponto de

\footnotetext{
364 AUGUSTO, Paulo Roberto Peloso. Tangos brasileiros: Rio de Janeiro: 1870 / 1920. Tese de doutorado em História. São Paulo: FFLCH-USP, 1996.

365 WISNIK, José Miguel. O coro dos contrários: música em torno da semana de 22. 2ª ed. São Paulo: Duas Cidades, 1983. Capítulo 4, pp. 140-174.

366 CONTIER, Arnaldo Daraya. Brasil Novo: música, nação e modernidade. Os anos 20 e 30. Tese de livre docência. FFLCH-USP, 1988, pp. 459-464.
} 
oferecer alguns elementos para a compreensão de suas análises do texto musical, sempre fica a impressão de que estas exposições são de difícil compreensão para não iniciados e superficiais para iniciados. ${ }^{367}$ Carlos Alberto Zeron, em Fundamentos histórico-políticos da música nova e da música engajada no Brasil a partir de 1962, realiza análise de diversos textos musicais de Gilberto Mendes e Willy Corrêa de Oliveira, todos incluídos no anexo de sua tese, conjunto bem organizado de partituras fundamentais desses autores, que até hoje tem circulação restrita.

Em Getúlio da Paixão Cearense (Villa-Lobos e o Estado Novo), Wisnik analisa o Choros nº 10 de Villa-Lobos, a partir da consideração de que "a peça admite um leitura sintático-semântica que acompanhe a articulação de gestos musicais nacionais", abordagem que o autor entende como adequada ao objeto apesar de "aparentemente demodée à primeira vista". ${ }^{368}$ No desenvolvimento desta análise, que evidentemente se construiu na leitura do texto musical, o texto propriamente dito não aparece, e ela é apresentada de forma a poder ser acompanhada pelo leitor apenas com a escuta musical, sem a necessidade de recorrer à partitura, o que é coerente com os objetivos do ensaio. Ainda assim, se utiliza de alguns termos técnicos como ancruse, segunda menor, acorde perfeito menor, tessitura, clusters, glissandos e stretto, o que parece inevitável neste tipo de análise. Mas, de um modo geral, esta abordagem é aparentemente mais inteligível quando o texto visa um público mais amplo do que aquele que domina a linguagem musical.

Até aqui, os trabalhos mencionados fazem a análise de obras do campo de produção erudita, ainda que estes estudos tenham em maior ou menor grau interseções com a historiografia da música popular. Os trabalhos de Paulo Roberto Peloso Augusto, Tangos brasileiros, e Sérgio Estephan, $O$ violão instrumental brasileiro, também se atêm a questões da estruturação musical expressas em partitura. Estas pesquisas estão entre aquelas que apresentam perfil mais musicológico dentre os

\footnotetext{
367 Apenas para dar um exemplo destas dificuldades, quando Contier aponta a "longa insistência sobre a harmonia de mi/fá sustenido" no $2^{\circ}$ e $3^{\circ}$ tempos do $3^{\circ}$ compasso do Choros no 2 de Villa-Lobos para flauta e clarinete em lá, esse dado não será localizado mesmo por um leitor familiarizado com a leitura da partitura, se ele não souber que o clarinete em lá é um instrumento transpositor (a partitura para o clarinete em lá é escrita uma terça menor - um tom e meio - acima do que ele realmente soa, ou seja, a nota dó escrita na pauta, quando tocada no instrumento soa como lá). Desta forma, o sol escrito na pauta do clarinete soa como mi e o fá\# está na parte da flauta. 368 WISNIK, José Miguel. Getúlio da paixão cearense (Villa-Lobos e o Estado Novo). In: Música: o nacional e o popular na cultura brasileira. São Paulo: Brasiliense, 1982, p. 167. Nessa passagem, o autor quase que se desculpa por fazer uma análise sintático-semântica do texto musical.
} 
trabalhos do nosso corpo documental. Ambas se dedicam à formação de gêneros e linguagens musicais no Brasil, no final do século XIX e início do século XX, e incluem partituras e gravações em anexo. Creio que em ambas aparecem as dificuldades de articulação das informações do contexto sócio-histórico com a análise musicológica do texto musical, de maneira a evitar que se constituíssem em duas análises paralelas, um desafio neste estágio inicial da pesquisa e problema metodológico ainda não plenamente resolvido, que será tema do próximo capítulo. Na verdade, em outro plano, esta questão também pode ser observada em Brasil Novo, de Contier, trabalho que inaugura esta abordagem da música na área de História. Sem dúvida, a análise das peças de Villa-Lobos (Choros no 2, Uirapuru, Dança do índio branco, Canto do Page e exemplos do canto orfeônico) enriqueceram o trabalho e encorparam a argumentação. São exemplos pertinentes e bem trabalhados. Nessa parte do trabalho, o autor busca uma articulação entre música e política a partir da análise do texto musical. Mas é difícil se depreender da análise do texto tudo o que está dito ali: as considerações não se sustentariam por si só, sem o concurso da argumentação que foi construída ao longo da tese. A análise musical apresenta-se mais como exemplificação e mesmo continuidade da argumentação, do que como geradora das conclusões.

Em Tangos Brasileiros, o primeiro capítulo, sobre o bota-abaixo do prefeito Pereira Passos e a Belle Époque no Rio de Janeiro, que teria a função de situar o contexto histórico do surgimento dos gêneros de música popular carioca, no meu entendimento, não está conectado com que o se segue, análise musicológica dos gêneros na qual as relações do texto musical com o contexto social apresentado no primeiro capítulo, não resulta claramente situada. Ao centrar sua atenção nos aspectos formais e de estruturação do texto musical, em diversos momentos o autor parece pender para a concepção de que a matriz fundamental dos gêneros em estudo (o tango brasileiro, a habanera, o maxixe e até o lundu) seria a música europeia.

Sergio Estephan inclui gravações e partituras apontando a escassez e a dificuldade de acesso a essas fontes dentro de seu recorte cronológico, e se utilizou de material localizado no acervo pessoal de Ronoel Simões e na Biblioteca Nacional. Ao analisar os gêneros de música popular entre o final do século XIX e início do XX, o autor faz uma discussão muito apoiada na estruturação musical conforme grafada na 
partitura, que apresenta as tradicionais dificuldades para definições precisas destes gêneros. Um exemplo interessante é a análise da peça clássica do repertório violonístico popular brasileiro Sons de Carrilhões, de autoria de João Pernambuco. 0 autor apresenta diferentes edições de transcrições para partitura da peça e as gravações do compositor, de Dilermando Reis, Turíbio Santos e Leo Brouwer. Discute as diferenças de tratamento rítmico nas partituras e nas gravações e as denominações de choro-maxixe ou (choro para violão) maxixe, presentes nesses textos. Em suas conclusões, o autor discorda da denominação choro-maxixe, por não reconhecer nessa peça a mescla desses gêneros que ele acredita terem identidade definida, coisa que não fica claro ao longo do trabalho. Entende que apenas na edição e gravação de Turíbio Santos é que se pode identificar a presença do maxixe. Porém, o autor informa que, ao consultar informalmente três violonistas pesquisadores, não encontrou consenso. "0 colecionador Ronoel Simões afirmou que Sons de Carrilhões é mesmo um maxixe. 0 musicólogo Paulo Castagna teve dúvida. Já o violonista Fábio Zanon não considerou a esta obra um maxixe”. De certo mesmo, só que não é valsa, como teria sido classificada em reportagem jornalística. ${ }^{369} \mathrm{Ou}$ seja, a passagem exemplifica os desafios, as dificuldades e limites destas classificações atendo-se estritamente ao texto musical. Aliás, o desafio da definição precisa destes gêneros, em termos estritamente de estruturação da linguagem musical, lembra a célebre passagem de Santo Agostinho acerca do tempo.

Enfim, é sintomático que todo o material submetido à análise estrutural nestas pesquisas, esteja composto por obras que, de um modo geral e em diferentes graus, melhor se prestam para análises dentro dos parâmetros mais convencionais da musicologia. É este o caso dos trabalhos de Villa-Lobos, das obras das vanguardas (que foram inovadoras em relação à tradição), da música solo para violão e da música popular no final do século XIX. Nas obras de Villa-Lobos, a fonte para análise foi a partitura, não sendo necessário recorrer-se à gravação, embora obviamente os autores partiram de uma escuta e esta seja fundamental para melhor entendimento do leitor, especialmente para aqueles que não dominam o código musical. Em relação aos

369 ESTEPHAN, Sérgio. O violão instrumental brasileiro: 1884-1924. Dissertação de mestrado em História. PUC-SP, 1999, p. 95. 
trabalhos da vanguarda analisados por Zeron, grande parte do material não se encontrava disponível em registro fonográfico quando da realização do trabalho, e o centro da análise ficou também no texto escrito. Peloso Augusto e Estephan, abordando objetos mais diretamente ligados à música popular, além de partituras, recorrem também a exemplos musicais em fita cassete anexa aos trabalhos para exemplificar suas afirmações.

No caso da partitura, sua análise e utilização como fonte de pesquisa histórica dispõe, como ponto de partida, das referências nas elaborações desenvolvidas na musicologia, em que pese as limitações da notação quando o assunto são músicas de vertentes distintas da tradição artística ocidental. Mas quanto ao fonograma, sua utilização como fonte de pesquisa histórica é algo recente. Fonograma aqui entendido na forma de gravação comercial, os registros sonoros lançados em discos em 78rpm, sucedidos pelos Long Plays e compactos em vinil e depois pelo CD e arquivos digitais para download. Desde o seu surgimento, a Etnomusicologia se utilizou do registro sonoro realizado no campo para o estudo das músicas de diversas culturas. Mas neste caso, trata-se de uma outra coisa, registro de músicas de tradição oral para estudo posterior, uma vez que sua notação em partitura não comportava todas a nuanças dessas músicas. No Brasil, temos como pioneiras as gravações realizadas pela Missão de Pesquisas Folclóricas organizada por Mário de Andrade em 1938.370 Entretanto, no que diz respeito à música popular urbana, no campo acadêmico, as pesquisas analisadas neste trabalho são evidentemente as primeiras. Nos estudos não acadêmicos que os antecederam, a utilização do fonograma foi pontual e não constituiu um modelo para utilização da gravação comercial como fonte de pesquisa histórica.

Tratando-se, portanto, de um tipo de documentação recém-incorporada aos estudos historiográficos, é também natural que tenha existido um certa hesitação em sua utilização, na medida em que inexistiam modelos anteriores em que se basear. Apenas pouco mais da metade dos trabalhos que estamos analisando apresentam uma discografia ou relação de fonogramas mais consistentemente listada nas fontes. 0 número é impreciso, pois as gravações estão apresentadas de diversas maneiras, mais ou menos organizadas, e, por vezes, não fica claro se é exatamente à gravação, e qual

370 MISSÃO DE PESQUISAS FOLCLÓRICAS - MÁRIO DE ANDRADE. Caixa contendo 6 CDs, livreto e 3 catálogos histórico-fonográficos. São Paulo: SESC, 2006. 
versão, que se está referindo. Por vezes, o autor se refere à gravação no corpo da tese, mas não a relaciona nas fontes, caso do livro Cantores do rádio, de Alcir Lenharo, e da tese No ar: amores amáveis, de Wolney Honório Filho, por exemplo.

Em alguns trabalhos, não encontramos nenhuma referência a gravações. Claro que, em alguns casos, precisam ser consideradas as diferenças de objetos de pesquisas, periodizações, existência e disponibilidade de registros sonoros comerciais. Samba da legitimidade, de Antonio Pedro, tem o grande desconto de ter sido o primeiro trabalho historiográfico. Nas tramas da fama, de Marta Avancini, e Cotidiano, memórias e tensões, de Raimundo Silva, têm o foco mais no circuito cultural, de produção, de práticas e sociabilidades em torno das estrelas do rádio, do que na canção propriamente dita. Para o estudo da música popular no final do século XIX e início do XX fora do Rio de Janeiro, como é o caso de Sonoridades Paulistanas, de Vinci de Moraes, os registros sonoros são escassos. No caso de Brasil Novo: música, nação e modernidade, de Arnaldo Contier, a fonte sonora era mesmo a partitura. Já os dois trabalhos sobre Chiquinha Gonzaga, A dama da boêmia, de Lícia Mascarenhas e Chiquinha Gonzaga no Rio de Janeiro da belle époque, de Cleusa Millan, poderiam ter se utilizado das raras gravações de época ou de outras mais recentes. Ainda que o foco do trabalhos não estivesse na sua música propriamente dita, seria interessante que o material existente tivesse sido ao menos inventariado.

Em alguns trabalhos, encontramos na discriminação das fontes uma relação das canções que foram citadas, discutidas ou analisadas. Em Dimensões da vida urbana sob o olhar de Chico Buarque, Miriam Noronha lista as canções de Chico Buarque mencionadas no trabalho, com a indicação do ano ao lado. Simone Luci Pereira, em Bossa Nova é sal, é sol, é sul, inclui nas suas fontes as canções e seus autores, que, no caso da bossa nova, muitas vezes não foram seus intérpretes nas gravações originais, embora a dissertação esteja acompanhada de uma fita cassete com algumas músicas analisadas, cuja seleção, segundo a autora, levou em conta as gravações mais ouvidas. Ana Barbara Pederiva, em Jovens tardes de guitarras, sonhos e emoções, indica compositor, intérprete e ano. Creio que, nestes e alguns outros trabalhos em que o fonograma (gravação comercial na qual a canção circulou e foi disponibilizada no mercado) não está precisamente relacionado nas fontes, isto se deve em parte à 
abordagem que se fez da canção, com o foco no texto literário, metodologia que será discutida no Capítulo 6. Neste caso, importava apenas a letra da canção, que tende a ser a mesma independente da versão e do intérprete. Mas, ainda assim, seria interessante precisar de onde vem a letra da canção que se cita no trabalho: ou ela vem de uma outra fonte escrita anterior (revista, songbook, livro, tese, internet) ou ela foi transcrita da fonte primária, o fonograma. ${ }^{371}$

Esta questão da citação da fonte é apenas um indicativo do estágio da utilização da fonte sonora na pesquisa historiográfica; a questão que realmente importa é como se deu sua utilização concreta na pesquisa. Nem sempre a inclusão da discografia na documentação indica necessariamente a utilização do fonograma no seu aspecto sonoro, ou seja, análise do componente musical da canção. Por exemplo, em $O$ sertão nos embalos da música rural, Wolney Honório Filho apresenta uma vasta discografia nas referências, mas não fica claro como o autor trabalhou com ela e em que medida a escuta do material teria influenciado no estudo do objeto, uma vez que a análise está centrada no componente literário da canção. Também Paulo Cesar de Araújo em Eu não sou cachorro, não, apresenta vasta discografia, mas não se utiliza de aspectos sonoros em sua análise da produção musical "cafona".

É claro que pesquisadores com formação musical ou trânsito pela musicologia tiveram mais facilidade ou segurança para análises do material sonoro, casos de Peloso Augusto, Estephan e Contier ${ }^{372}$, por exemplo. Por outro lado, por vezes, músicos com formação não se utilizaram de fontes sonoras, em função das características de seu objeto. Carlos Drehmer, músico de sólida formação e professor no Instituto de Música da Universidade Católica do Salvador (UCSAL), não se utiliza de gravações em sua dissertação sobre as práticas violonísticas nas décadas de 1950 e 1960 na capital da Bahia, ${ }^{373}$ uma vez que estas não foram registradas. E nem por isso a dissertação deixa

\footnotetext{
371 A norma da ABNT NBR6023:2002 dispõe, nos itens 7.13 e 7.14 e respectivos subitens, sobre a citação de documentos sonoros. A concepção é a mesma utilizada para a citação de textos, considerando elementos essenciais compositores, intérpretes, título, local, gravadora, data e especificação do suporte. Nos exemplo, a chamada é feita pelo nome do compositor ou pessoa, no caso de outro tipo de registro sonoro (depoimentos, discursos, etc.). Pode ser uma forma de padronizar essas citações. Mas a norma não é tão precisa como para as citações de textos escritos e não parece que tenha resolvido plenamente a questão, permanecendo ambiguidades como fazer a chamada pelo nome do compositor ou nome artístico, casos de coletâneas e outras. Praticamente cada autor utilizou um método e talvez o mais aconselhável não seja seguir a norma, mas a forma que propiciar maior clareza no caso específico.

372 CONTIER, Arnaldo Daraya. Edu Lobo e Carlos Lyra: o nacional e o popular na canção de protesto (os anos 60). São Paulo: Revista Brasileira de História, vol. 18, n. 35, 1998.

373 DREHMER, Carlos Edmundo Chenaud. Violão, violonistas e memória social nas décadas de 50 e 60 em Salvador. Dissertação de mestrado em História. PUC-SP.
} 
de contemplar os aspectos sonoros possíveis, ao discutir as práticas, técnicas e formas de aprendizado e transmissão do conhecimento musical. Isto ocorre também em outros estudos para os quais o som propriamente dito não está disponível, como em Sonoridades Paulistanas, de Vinci de Moraes. Mas no caso do trabalho de Drehmer, poderiam ter sido realizadas gravações, mesmo que informais, com os remanescentes da época, que ele entrevistou (e tocou junto, como ele relata), ter utilizado algum material do grupo de choro Os Ingênuos (ainda atuante, bastante mencionado na pesquisa), o que dependeria de direitos autorais ou ele mesmo poderia ter gravado alguns exemplos musicais ao violão, como os que ele tocou na defesa da dissertação, que enriqueceram a exposição do trabalho.

Em O combate ao samba e o samba de combate, João Ernani Furtado Filho inclui nas suas fontes fonográficas uma tabela na qual relaciona diversas canções coletadas no Arquivo Miguel Ângelo de Azevedo (Nirez), de Fortaleza, em gravações originais de 78rpm. O autor apresenta da seguinte maneira sua proposta de abordagem metodológica desta discografia:

\begin{abstract}
Um último aspecto que pode ser abordado diz respeito à forma de utilização dos materiais discográficos. Nesse sentido, deve-se esclarecer que o percurso metodológico utilizado baseava em uma estratégia de "análise de discurso", mas um discurso que não fosse consubstanciado apenas à letra da composição, mas que também levasse em conta os aspectos musicais (harmonia, melodia e ritmo) e interpretativos (arranjo, voz, emissão, dicção). Todavia, para não tornar o texto enfadonho ou difícil, optou-se por apresentar de forma sucinta e com uma linguagem não muito especializada algumas destas questões. Mais que isso, deve-se dizer que este percurso não foi utilizado em todas as composições listadas, o que deveu-se em larga medida à escassez de pautas feitas a partir das gravações originais. ${ }^{374}$
\end{abstract}

Entretanto, esta proposição ficou mais no plano das intenções, uma vez que o estudo se apoia, fundamentalmente, na análise do texto literário das canções. Em raros momentos, encontramos menções a aspectos sonoros, como na interessante passagem na qual o autor mostra como o ritmo de samba mudava o sentido de textos de canções que indicavam que o negro, ou o brasileiro de um modo geral, deveria largar o samba e pegar no fuzil. ${ }^{375}$

\footnotetext{
374 FURTADO FILHO, João Ernani. O combate ao samba e o samba de combate: música, guerra e política, 1930-1940. Dissertação de mestrado em História. São Paulo: PUC/SP, p.10.

375 Ibidem, pp. 126-127.
} 
Considerando que, de um modo geral, as pesquisas historiográficas sobre música popular são desenvolvidas por pesquisadores que possuem um certo nível de vinculação com o objeto, é razoável supor que estes tenham feito uma audição qualificada da discografia relevante e muitas vezes a escolha do objeto se deu por uma escuta realizada ao longo da vida, como alguns autores mencionam. Podemos então especular que, nos casos em que essa escuta não aparece e os aspectos sonoros não são contemplados na análise, isso pode ser decorrência do receio de cometer impropriedades, uma resistência em enveredar por um campo cujos fundamentos não se domina. ${ }^{376}$

Entre os trabalhos que incorporam análises de aspectos sonoros a partir da escuta, em distintos níveis e perspectivas, podemos citar Trilha Sonora, de Fátima Amaral Dias de Oliveira; Custódio Mesquita, um compositor romântico, de Orlando de Barros; Metrópole em Sinfonia, de José Geraldo Vinci de Moraes; Seguindo a canção, de Marcos Napolitano. Fátima Amaral faz tentativas de contemplar aspectos sonoros na análise do discurso das canções, como quando discute a canção Ladeira da Memória, do Grupo Rumo. ${ }^{377}$ No caso deste trabalho, estudo das percepções do cotidiano na cidade de São Paulo através do que a autora considera ser sua "trilha sonora", a inclusão de aspectos sonoros é fundamental. Amaral incorpora também aspectos visuais com diversos quadrinhos de Luiz Gê, cuja linguagem teria conexões com a produção musical de Arrigo Barnabé. Em Custódio Mesquita, um compositor romântico, Orlando de Barros demonstra a compreensão da canção em sua relação texto-melodia. Por exemplo, quando fala do famoso foxtrot Nada Além e da valsa Velho Realejo, o autor faz comentários sobre a instrumentação característica destes gêneros, e fala do fox sem

\footnotetext{
376 De fato, numa leitura mais rigorosa, é possível encontrarmos em alguns trabalhos, algumas imprecisões terminológicas ou pequenos equívocos teóricos. Mas não se trata de algo muito relevante, que comprometa os trabalhos em suas questões centrais ou desaconselhe incursões pelo campo musicológico. 0 que a pesquisa ganha com a incorporação dos aspectos sonoros na análise compensa eventuais imprecisões. Seria entretanto apropriado para pesquisadores leigos em teoria musical, submeter essas passagens a uma leitura crítica de alguém da área de Música.

377 Após a letra de Ladeira da Memória, segue análise da canção que se inicia com o seguinte parágrafo: “A música começa com um soluço e depois um violão marca o ritmo que dá a impressão de passos descendo a ladeira, fortes, mas contidos, brecados, "até o Vale do Anhangabaú"; então o ritmo se suaviza, como quando acaba a ladeira e os pés caminham com mais suavidade, a música se espraia como a multidão que se dispersa anônima, desinteressada do trabalho, mostrando um interesse difuso por tudo, "namorando, andando, andando, namorando". Em seguida entra um violão de12 cordas e um côco, o clima carrega, fica mais denso e o côco marca suavemente um outro ritmo:... "o céu ficou cinza e de repente trovejou e a chuva vem caindo, caindo, caindo". A seqüência se repete na voz de Ná Ozzeti e o arranjo incorpora mais instrumentos: xilofone, bateria, afoché, para construir com extrema delicadeza uma ressonância musical das cenas evocadas pela letra. OLIVEIRA. Fátima Amaral Dias de. Trilha sonora: topografia semiótica das canções independentes das décadas de setenta e oitenta. Dissertação de mestrado em História. Campinas: IFCH-UNICAMP, p.16.
} 
xenofobia, sempre afirmando a influência do gênero na canção brasileira do período, questão geralmente desconsiderada por autores que se prendem à letra das canções. ${ }^{378}$

\title{
5.2 A SELEÇÃO DAS FONTES: TENDÊNCIA PARA UM REPERTÓRIO CANÔNICO
}

Este item está dedicado a uma reflexão acerca da definição de objetos privilegiados e seleção do material musical a ser estudado (quais gêneros e movimentos musicais e, dentro deles, quais músicas). A dissertação de Paulo Cesar de Araújo, Eu não sou cachorro, não: música popular cafona e ditadura militar, apresentou uma leitura crítica da documentação mais frequentemente utilizada na historiografia da música popular e mostrou como ela contribuía na construção de uma certa memória da música popular no Brasil. Iniciou assim uma revisão importante da narrativa até então dominante sobre a música popular no Brasil. Araújo colocou a questão nos seguintes termos:

\begin{abstract}
Não dá mais para dissimular ou esconder. A produção musical "brega" ou" cafona" é um fato da nossa realidade cultural e, assim como a da bossa nova ou a do tropicalismo, precisa ser pesquisada e analisada. Ressalvo que este não é um livro de crítica musical, portanto, o autor não emite qualquer juízo de valor estético - nem para as canções de Waldik Soriano, nem para as de Caetano Veloso - ambas tratadas como documentos da história brasileira. Mas através da análise da construção social da memória é possível identificar de que maneira ficou cristalizada em nosso país uma memória da história musical que privilegia a obra de um grupo de cantores/compositores preferido das elites, em detrimento da obra de artistas mais populares. É possível que você não conheça ou tenha dificuldade de identificar alguns dos nomes de cantores e canções que serão aqui apresentados, mas isto pode ser apenas mais um reflexo do processo de silenciamento que atinge esta geração de artistas" cafonas". 379
\end{abstract}

De fato, se tomamos a música como fonte de pesquisa histórica, como documento de uma época, a questão estética não importa, é irrelevante ou nula, do ponto de vista da seleção do material. É indiferente, quando tomamos a música como documentação para o estudo de um determinado contexto histórico-social, nossa

\footnotetext{
378 BARROS, Orlando de. Custódio Mesquita, um compositor romântico: o entretenimento, a canção sentimental e a política no tempo de Vargas (1930-1945). Tese de doutorado em História. FFLCH-USP. Segundo Barros: "tanto os fox quanto as valsas são tão requeridos nos anos 30 e 40, que alguns compositores, e nem menos Custódio Mesquita, estavam sempre compondo esses gêneros, ao mesmo tempo que faziam seus sambas e marchas." (p. 129)

379 ARAÚJO, Paulo César de. Eu não sou cachorro não: música popular cafona e ditadura militar. 4a ed. Editora Record, 2003, p. 17.
} 
valoração estética acerca da música que se consumia. É certo que, observações acerca das qualidades artísticas, do grau de complexidade da estruturação, do nível de abstração e elaboração técnica, podem nos oferecer informações sobre a cultura da época. Mas considerações desse tipo não devem direcionar a escolha do material, a menos que o objetivo seja uma história da estética ou das formas musicais (o que não é o caso de nenhum dos trabalhos do nosso corpo documental), ou assumidamente o estudo de um certo gênero ou repertório, por suas implicações políticas ou ligações com grupos ou contextos socioculturais. Por exemplo, Schümann Lima em Brutalidade e jardim, ao escolher como objeto de estudo as imagens de nação da tropicália, tinha clareza de estar trabalhando com um repertório de circulação restrita:

\footnotetext{
Temos a clara noção de estarmos construindo uma História sobre as ideias de um grupo social que não corresponde a grande massa de brasileiros, vale lembrar que Caetano Veloso é um cantor de uma parcela da juventude, basicamente urbana com certo nível de instrução e segundo a imprensa da época o campeão de vendagem de 1968 foi o samba Segura este samba Ogunhê, de Oswaldo Nunes. ${ }^{380}$
}

Parece não ser difícil constatar que a historiografia da música popular no Brasil em geral, e a pesquisa acadêmica em particular, privilegia (ou privilegiou até 1999) um certo repertório, consciente ou inconscientemente. Que uma determinada pesquisa se debruce sobre um repertório específico, como o estudo de Schümann Lima acerca das ideias político-culturais da tropicália, é algo absolutamente normal e legítimo. Mas que o conjunto da historiografia privilegie um certo repertório, consumido apenas por uma faixa da população e em torno do qual se podem articular certas concepções sociopolítico-culturais, isso é uma questão para reflexão. 0 que terá acontecido com Oswaldo Nunes e Segura este samba Ogunhê (e tantas outras canções e compositores que foram sucesso de público) e com os seus ouvintes? Qual teria sido a participação e o peso dessas pessoas nas lutas políticas de sua época? Devemos nos perguntar se, ao não incorporarmos estas fontes em nossas análises, não estaríamos perdendo muito em nossa compreensão dos processos históricos, se esse for o objetivo da pesquisa. A questão que se coloca é até que ponto as fontes privilegiadas na historiografia se

\footnotetext{
380 LIMA, José Edson Schümann. Brutalidade e jardim: as imagens da nação da tropicália. Dissertação de mestrado em História. UFRJ, p.6. O leitor pode ouvir Segura este samba Ogunhê, de Oswaldo Nunes, em: <http://letras.terra.com.br/oswaldo-nunes/713462/>
} 
confundem com um repertório canônico, tendendo assim a reproduzir certos discursos e ideias, tanto acerca da música quanto acerca da história do Brasil.

Em diversos momentos desta tese, está colocada (e questionada) a existência de um repertório canônico na música popular brasileira, que estaria expresso na linhagem samba-bossa-MPB. Torna-se então necessário observar mais de perto o conceito de cânone na cultura ocidental e abrirei aqui um longo parênteses para esta questão. Originária do grego antigo (kanôn), a palavra foi utilizada no latim para designar o conjunto de livros sacros de inspiração divina. Por extensão, passou a designar na literatura, nas artes visuais e na música ocidental, aquele conjunto de autores e obras-primas fundamentais que todos deveríamos conhecer e reverenciar. Estas obras - livros, edifícios, pinturas, músicas - seriam aquelas reconhecidas e legitimadas em seu valor estético, autorizadas para a contemplação e estudo sistemático, constituindo a espinha dorsal da história destes campos. Seus autores comporiam assim, o panteão de gênios criadores da nossa cultura. Formados ao longo do tempo num processo histórico e sociocultural complexo, estes cânones não são uma lista fechada de autores e obras universalmente aceitas; as "listas" podem diferir entre distintos autores, mas existem eixos fundamentais aceitos por todos. Shakespeare sempre figurará numa lista dos grandes escritores de todos os tempos, assim como Leonardo da Vinci nas artes plásticas e Beethoven entre os músicos.

No caso da música, o cânone se estabelece a partir do início do século XIX, sendo sua primeira manifestação o culto da trindade Haydn, Mozart e Beethoven. É a partir do século XIX que se incorporam ao repertório músicas de épocas anteriores, quando se "descobre" que a música tinha uma história que deveria ser preservada. Até então, a música executada era aquela contemporânea ou de, no máximo, uma ou duas gerações anteriores, como aponta Kerman, embora o autor localize algumas exceções (o cantochão, a música da Reforma e as óperas de Jean-Baptiste Lully na França). ${ }^{381}$ Foi ao longo do século XIX que se constituiu o cânone musicológico, composto de um panteão de gênios criadores (Bach, Handel, Haydn, Mozart, Beethoven, Schubert,

\footnotetext{
381 Para uma história e discussão da formação do cânone na música ocidental ver KERMAN, Joseph. A few canonic variations. Critical Inquiry: The University of Chicago Press, vol. 10, no1, pp. 107-125, 1983; WEBER, William. The eighteenth-century origins of the musical canon. Journal of the Royal Musical Association, vol. 114, no 1, pp. 6-17, 1989. Para um crítica dos cânones da música ocidental, ver BERGERON, Katherine; BOHLMAN, Philip. (eds.) Disciplining Music: musicology and its canons. The University of Chicago Press, 1992.
} 
Schumann, Mendelssohn, Chopin, Liszt, Wagner e Brahms, com algumas variações) ${ }^{382}$, de suas obras-primas (com especial destaque para sinfonias, concertos, quartetos de cordas, sonatas, óperas e lieder), mas também de um instrumental teórico, de metodologias e ferramentas analíticas voltadas para este repertório. Assim, o cânone tende a se reproduzir, uma vez que compõe a maior parte do repertório executado, estudado nas escolas de música e as ferramentas analíticas tradicionais irão confirmar sua superioridade, posto que foram concebidas para o seu estudo.

Desde o seu surgimento, a Etnomusicologia questionou o cânone musical ocidental tradicional e, a partir da década de 1980, setores da Musicologia incorporaram a reflexão sobre a questão do cânone (ou dos cânones, considerando-se que outras tradições também constituíram seus cânones, o jazz e o rock, por exemplo) no processo de renovação da disciplina, que será abordado no capítulo seguinte. Entre os principais questionamentos, encontram-se o eurocentrismo (com a predominância da música alemã), a misoginia (praticamente não há mulheres no cânone musical), a centralidade da notação, da análise, as concepções de performance, além das fraturas ou rupturas provocadas pelas vanguardas. Por outro lado, surgiram também discursos em defesa do cânone que não podem ser desconsiderados. No plano da literatura, Harold Bloom apresenta em $O$ cânone ocidental ${ }^{383}$ uma relação de vinte e seis escritores que considera essenciais em nossa cultura. Em sua Elegia para o cânone, título do primeiro capítulo, Bloom faz uma argumentação numa linha de valorização da alta cultura e da estética superior destas obras fundamentais. Classifica os adversários do cânone, como os marxistas, especialmente na vertente gramsciana, e os multiculturalistas, com o rótulo pejorativo e polêmico de "Escola do Ressentimento". Entretanto, alguns de seus argumentos precisam ser considerados seriamente. Para Bloom, se fôssemos imortais, o cânone seria desnecessário. Entretanto, uma vez que somos mortais e nosso tempo é limitado, não é possível lermos toda a literatura

\footnotetext{
382 No Prólogo de Disciplining Music, Katherine Bergeron apresenta uma visão materializada do cânone musical: "In Paine Concert Hall at Harvard University, the names of great composers from Monteverdi to Tchaikovsky are painted in fine, Roman capitals. They line the ceiling and look down on the chairs, capturing listeners in a permanent, austere gaze. Our musical Fathers stand in gold leaf, protected, enshrined, preserved (as Frank Kermode would say) in a continuous state of modernity: Beethoven in front and Center, flanked by Mozart and Schubert; the rest fall in like so many ranks of troops. It is the Canon at a glance; a solemn spectacle of the disciplining music." (p. 1) 383 BLOOM, Harold. O cânone ocidental: os livros e a escola do tempo. Rio de Janeiro: Editora Objetiva, 2001. Título original: The Western canon: the books and the school of the ages, 1994.
} 
disponível. Aliás, a própria leitura de todas as obras que podem ser consideradas canônicas já seria praticamente impossível. Podemos imaginar que, da mesma forma, a escuta e estudo de tudo o que se produziu em música é inviável, e mesmo a escuta do repertório canônico da tradição ocidental, sem dúvida, um patrimônio da humanidade, seria uma empreitada para uma vida inteira. Assim, talvez seja mais prudente evitar as posições extremadas e, em vez de simplesmente desconsiderar o cânone ocidental, parece mais apropriado assumir que ele tem sua utilidade para a orientação e fruição de uma certa tradição artística, desde que considerado sob uma perspectiva crítica e histórica.

No entanto, para o historiador da arte, o cânone pode ser uma armadilha. Orientar-se unicamente por ele significa renunciar à pesquisa original de fontes e reproduzir os discursos tradicionais. A ideia dos grandes autores e obras, bem de acordo com o paradigma historiográfico herdado do século XIX, foi fundamental para a construção do discurso predominante na história da música ocidental e, via de regra, foi reiterada pelos estudiosos da música popular até recentemente. Assim, no caso da música popular no Brasil, também temos nosso panteão de gênios criadores, Noel Rosa e Pixinguinha à frente, numa vertente mais tradicional, sucedidos por Tom Jobim, Chico Buarque, Caetano Veloso e Gilberto Gil, para aqueles que se orientam pela ideia da "linha evolutiva". Temos também um repertório de obras e uma sucessão de gêneros que constituem a linhagem daquilo que se entende por música popular brasileira ou MPB, conforme discutido no Capítulo 3.

Paulo César Araújo apontou que a bibliografia sobre música popular brasileira não apresentava estudos focalizando a obra do repertório "cafona", restringindo-se a maior parte dos títulos publicados aos sambistas dos anos 1930, à bossa nova e à geração surgida durante os festivais de música popular nos anos 1960. Ou seja, o que estaria sendo pesquisado e analisado seria basicamente a produção dos cantores e compositores identificados com a tradição que se organizou em torno da MPB. Araújo argumentou que, na vasta obra de Tinhorão, não se encontrava nada sobre os "cafonas", assim como em Ary Vasconcelos, Sérgio Cabral, Ruy Castro, Zuza Homem de Melo e outros, ou na coleção História da Música Popular Brasileira da Abril Cultural ou nos depoimentos do Museu da Imagem e do Som do Rio de Janeiro. Na historiografia 
acadêmica até o período que estamos analisando, existe uma amplitude maior em relação aos gêneros musicais do que na corrente historiográfica mencionada por Araújo, conforme vimos no Capítulo 3, mas pode-se constatar ainda o predomínio de uma certa linhagem da música popular no Brasil e de algumas polêmicas estéticopolíticas que deixam grande parte da produção e das práticas musicais populares à margem do debate.

\begin{abstract}
Isto tudo nos remete à reflexão acerca dos silêncios da História. Jacques Le Goff, historiador francês, afirma que é preciso interrogar-se sobre os esquecimentos, os hiatos, os espaços em branco. "Devemos fazer o inventário dos arquivos do silêncio, e fazer a história a partir dos documentos e das ausências de documentos." E esta análise é de fundamental importância porque o espaço da memória constitui permanente campo de batalha, e o ato de esquecer pode ser resultado de manipulação exercida por grupos dominantes sobre dominados, ou de vencedores frente a vencidos. 384
\end{abstract}

Segundo Araújo, este esquecimento, de alguma forma, comprova o que foi observado pelo filósofo francês Edgar Morin ao dizer que geralmente "aquilo que se despreza não merece ser estudado ou pensado". É interessante observar que, para questionar o silêncio sobre os cafonas, Paulo César cita o texto clássico de Edgar Morin, Não se conhece a canção, ${ }^{385}$ muito utilizado nas primeiras pesquisas para defender a presença da música popular no campo científico, objeto então desprezado pelos setores tradicionais do meio acadêmico. 0 argumento é forte.

Os silêncios apontados por Paulo Cesar podem ser estendidos para outros gêneros de grande impacto popular, como o sertanejo, o pagode e a axé music, os dois últimos, fenômenos mais recentes. 0 sertanejo, como já apontado, foi objeto de alguns estudos, embora poucos, se considerarmos sua imensa repercussão social. ${ }^{386}$ Estes gêneros tem despertado mais atenção em outra áreas das Humanidades, mas mesmo aí, é curioso notar como o rap, por exemplo, é muito mais favorecido como objeto de estudo, embora seja aparentemente consumido por uma população significativamente menor. Entre 1971 e 2004, foram realizadas no Estado de São Paulo 258 pesquisas com

\footnotetext{
384 ARAÚJO, Paulo César de. Eu não sou cachorro não: música popular cafona e ditadura militar. 4aㅡ ed. Editora Record, 2003, p. 23.

385 MORIN, Edgar. Não se conhece a canção. In: Linguagem da Cultura de Massas: televisão e canção. Coleção Novas Perspectivas em Comunicação no 6, Vozes, 1973.

3860 processo de sofisticação enquanto produto midiático e formatação do gênero para atingir camadas mais amplas da população continua em curso. Parece também que nos últimos anos o gênero vem ganhando maior destaque nos estudos acadêmicos, a exemplo do trabalho de Allan de Paula Oliveira, Miguilim foi pra cidade ser cantor: Uma antropologia da música sertaneja, tese de doutorado em Antropologia, UFSC, 2009.
} 
temáticas em torno da música popular urbana em diversas áreas do conhecimento. Apenas uma delas se atém a essa faixa da produção que se chamava pejorativamente de "brega". Em torno do rap, foram realizados onze trabalhos e outros onze sobre música caipira ou sertaneja. Mas neste último caso, deve-se considerar o peso do gênero no interior de São Paulo, onde foram realizadas a maior parte destas pesquisas. ${ }^{387}$

No campo de estudos da música popular, objeto com o qual em geral temos uma ligação pessoal afetiva, é muito difícil se despojar de qualquer valoração estética. 0 gosto pessoal na escolha dos objetos de pesquisa geralmente está presente, mesmo quando não explicitado (e é melhor que seja explicitado). Muitas vezes a ligação do pesquisador com o objeto acaba "vazando" no trabalho: na utilização de adjetivos, na construção das frases, na forma condescendente como se abordam os aspectos negativos, por vezes pode-se perceber que o autor é um entusiasta do gênero musical que está estudando. Um certo nível de vinculação do autor com o objeto musical está presente em praticamente todos os trabalhos, mas a condição de scholar-fan é, em geral, mais acentuada na historiografia dos gêneros e "movimentos" musicais e nos estudos biográficos.

Esta questão da relação afetiva com o objeto vale também para Paulo Cesar Araújo. Em muitos momentos do seu livro, ele se coloca quase como um simpatizante e defensor dos "cafonas" desprezados e esquecidos pela "corrente majoritária" da historiografia, minimizando seus deslizes e valorizando suas façanhas. Por vezes seu discurso ganha tons sensacionalistas e apologéticos, com certo ressentimento em relação às correntes hegemônicas. 0 que é perfeitamente compreensível. Como disse Antonio Candido, nada mais importante para chamar a atenção sobre uma verdade do que exagerá-la, mas nada também mais perigoso, pois em algum momento a reação inevitável a relega à categoria de erro, até que se estabeleça um ponto de vista equilibrado e objetivo. ${ }^{388} \mathrm{Em}$ alguns momentos, seu discurso tende para uma visão de que a valorização na historiografia de uma certa linhagem da música popular, consumida pelas classes médias, se deveria ao pertencimento de seus autores a essas camadas da sociedade. Seu interesse pelo objeto teria se dado na escuta dos "cafonas",

\footnotetext{
387 BAIA, Silvano Fernandes. A pesquisa sobre música popular em São Paulo. Dissertação de mestrado em Música. São Paulo: IA-UNESP, 2005, p. 104.

388 CANDIDO, Antonio. Literatura e sociedade: estudos de teoria e história literária. São Paulo: Companhia Editora Nacional, 1965, p. 3.
} 
que era a música ouvida nas camadas sociais das quais é oriundo. Creio que a preferência e valorização na historiografia da linhagem em torno da tradição do samba carioca e da MPB está mais relacionada a questões de concepções políticas, estéticas e ideológicas do que propriamente à origem social de seus proponentes, ainda que possa existir um certo nível de articulação entre a condição social dos pesquisadores e as concepções mencionadas.

Uma vez apresentada esta questão mais geral da seleção do repertório a ser estudado, vamos observar a questão do acesso à documentação, tal como ela aparece nas pesquisas. É um fato já muitas vezes relatado, as dificuldades de acesso a essas fontes (partituras, gravações e documentação relativa à produção), com a desorganização e descontinuidade dos acervos, especialmente quando a periodização se situa antes da década de 1960. Não houve por parte das gravadores ou de outras instituições uma política de preservação deste patrimônio cultural, e os acervos hoje disponíveis devem sua existência às iniciativas e ao empenho de aficionados, colecionadores e estudiosos como Almirante, Tinhorão, Nirez, Ronoel Simões, Humberto Franceschi, Jairo Severiano, entre outros. Este material recolhido por estes pesquisadores constitui uma preciosidade, mas naturalmente, sua organização e seleção esteve sujeita aos critérios estéticos destes estudiosos e suas linhas ou interesses de pesquisa. Estes e outros acervos se constituíram inicialmente como coleções pessoais, não tendo por objetivo a memória da música popular em abstrato. A seleção do que colecionar e o que descartar passava fundamentalmente pelo crivo da condição de pesquisador aficionado, o que é válido para a composição de discotecas e arquivos pessoais de um modo geral. ${ }^{389}$ Para as primeiras pesquisas, o acesso a esse material era mais complicado, dependendo em grande parte da generosidade destes colecionadores; hoje, o acesso a este material já se encontra mais democratizado, por iniciativa mesmo destes pesquisadores, seja por doações ou transformação de suas coleções em arquivos públicos, como será observado adiante, ou publicações com informações acerca da discografia. Em 1982, foi publicada a Discografia Brasileira em 78rpm (1902-1964), organizada por Alcino Santos, Gracio Barbalho, Jairo Severiano e

389 Canclini discute como o patrimônio se apresenta de forma muitas vezes neutra, encobrindo as contradições que o constituíram. CANCLINI, Nestor Garcia. Culturas híbridas. São Paulo: EDUSP, 1998, p. 160. 
Miguel Ângelo de Azevedo (Nirez). ${ }^{390}$ Este trabalho, inventário de longo fôlego em forma descritiva das chamadas gravações de cera produzidas no Brasil, tem cerca de 3.000 páginas divididas em cinco volumes e procura obedecer, na medida do possível, a ordem cronológica do lançamento dos discos. Estende-se pelos cerca de 7.000 discos da fase da gravação mecânica (1902-1927) e cerca de 20.000 da fase elétrica em 78rpm (1927-1964). Os fonogramas são apresentados por gravadora, número do disco, repertório, gênero, número da matriz, intérprete(s), autor(es), data da gravação e data do lançamento, mas nem sempre todos estes dados estão disponíveis. A coleção de Humberto Franceschi, atualmente no IMS, ${ }^{391}$ serviu de base para a publicação de $A$ casa Edson e seu tempo, ${ }^{392}$ bem cuidada edição que conta com 9 CDs de músicas e imagens, e da coleção Memórias Musicais, caixa com 15 CDs com gravações da Banda do Corpo de Bombeiros, Banda da Casa Edison, Pixinguinha, Patápio Silva, entre outros, feitas entre 1902 e 1950. Também o livro A canção no tempo: 85 anos de músicas brasileiras, ${ }^{393}$ oferece informações relevantes. O livro pretende apresentar as canções de maior sucesso de público, ano a ano. A seleção destes "sucessos" foi feita basicamente em dois planos: "canções que obtiveram sucesso ao serem lançadas - não importando sua qualidade ou permanência - e as que não obtiveram sucesso imediato, mas, em razão de sua qualidade, acabaram por merecer a consagração popular", além de restringir a escolha ao âmbito nacional, evitando sucessos exclusivamente regionais. Como isto é praticamente impossível de se quantificar por critérios objetivos, é inevitável a subjetividade na seleção do material e o texto, embora útil como referência, apresenta alguns dos problemas metodológicos que estão em foco neste capítulo.

Esta questão do acervo se coloca de uma outra maneira para pesquisas com o foco em eventos a partir da década de 1960, momento em que se dá a consolidação do

390 AZEVEDO, Miguel Ângelo de (Nirez) et all. Discografia brasileira, 78rpm, 1902-1964. Rio de Janeiro: FUNARTE, 1982.

391 O importante acervo do Instituto Moreira Salles (IMS) começou a ser construído em 2000, portanto não se reflete nos estudos que dão base a esta pesquisa, todavia é mais um local de referência e sua organização aponta para uma maior preocupação da sociedade com a memória cultural. Seu acervo reúne cerca de 100 mil músicas (entre as quais, 25 mil gravações digitalizadas) e grandes coleções de outra linguagens artísticas. Entre as coleções do IMS encontra-se a de José Ramos Tinhorão. 0 acervo de Tinhorão foi incorporada pelo museu em 2001, após negociação com o pesquisador, e contém discos, partituras, fotos, filmes, scripts de rádio, programas de cinema e teatro, cartazes, jornais, revistas e uma biblioteca especializada. Parte de sua discoteca, que inclui uma coleção com cerca de 6,5 mil discos de 78rpm, está disponível on-line. O IMS conta também como a coleção de Humberto Franceschi, parte da qual serviu de base para a edição de A casa Edson e seu tempo. O IMS vem incorporando ao seu acervo outras coleções: conta atualmente com os arquivos pessoais de Ernesto Nazareth, Pixinguinha e Chiquinha Gonzaga. 392 FRANCESCHI, Humberto. A casa Edson e seu tempo. Rio de Janeiro: Sarapuí, 2002.

393 MELlO, Zuza Homem de. SEVERIANO, Jairo. A canção no tempo: 85 anos de músicas brasileiras. 2v. São Paulo: Editora 34. Vol.1 (1901-1957), 1997; Vol.2 (1958-1958), 1998. 
Long Play (LP) em vinil. $\mathrm{O}$ acesso às fontes é obviamente mais fácil neste período mais recente e, em geral, os pesquisadores arrolaram na discografia a listagem das gravações utilizadas como fonte sem necessidade de mencionar arquivos, utilizando-se de acervos pessoais previamente existentes ou organizados para a pesquisa. Porém, se por um lado, o acesso aos fonogramas é mais fácil, por outro, não existe um levantamento exaustivo sobre o LP no Brasil, similar aos realizados em 78rpm. Não há uma "discografia brasileira em Long Play", o que tende a acentuar certos silêncios e esquecimentos, direcionando os pesquisadores àquilo que o mercado preservou, que os colecionadores reiteraram e o que foi canonizado ou ganhou destaque em narrativas anteriores.

Em função da grande diversidade de períodos e gêneros estudados e à dispersão e desorganização da documentação já mencionadas, os pesquisadores foram buscar em diversos locais as fontes para seus estudos, variando muito de trabalho para trabalho. Mas alguns acervos são mais recorrentes, especialmente em relação aos estudos cuja periodização se situa até meados do século XX. São eles, a Biblioteca Nacional, o Arquivo Nacional, o Museu da Imagem e do Som do Rio de Janeiro (MIS-RJ), o Museu da Imagem e do Som de São Paulo (MIS-SP), o Arquivo Nirez, o Arquivo Mário de Andrade do Instituto de Estudos Brasileiros da USP (IEB-USP), o Centro Cultural de São Paulo e a Biblioteca Mário de Andrade.

Para uma história do samba, ou do rádio, por exemplo, o Museu da Imagem e do Som do Rio de Janeiro é um acervo fundamental. Inaugurado em 1965, recebeu, por ocasião de sua fundação, a coleção do radialista Henrique Foréis Domingues (Almirante), a coleção de discos raros de Lúcio Rangel e as litogravuras de Maurice Rugendas, entre outras coleções particulares. Foram incorporadas ao longo do tempo diversas coleções, como a da Rádio Nacional (1972), a de Jacob do Bandolim (1974), de Elizeth Cardoso (1979), de Abel Ferreira (1980), de Nara Leão (1990), de Sérgio Cabral (2007), entre outras. Além da guarda e preservação destas coleções, o MIS produziu sua própria documentação através da coleta dos Depoimentos para Posteridade, projeto concebido em 1966 e ainda em curso, com depoimentos de personagens dos mais variados ramos da cultura nacional, com destaque para a música popular. 0 primeiro depoimento foi prestado por João da Baiana, e apenas o seu primeiro ano de existência 
inclui os nomes de Ataulfo Alves, Bororó, Braguinha, Capiba, Dorival Caymmi, Heitor dos Prazeres e Pixinguinha, além do então jovem Chico Buarque de Hollanda entre outros personagens de variadas linguagens artísticas. 0 projeto vem incluindo compositores e pesquisadores mais recentes, compondo um acervo de quase mil depoimentos com, aproximadamente, quatro mil horas de gravação abrangendo os mais diversos segmentos da cultura. Alguns destes depoimentos foram transcritos no livro As Vozes Desassombradas do $M u s e u,{ }^{394}$ com depoimentos de Pixinguinha, João da Baiana e Donga, que ampliou muito o acesso e a circulação desse material. Publicado em 1970, tornou-se referência importante nas pesquisas pioneiras das décadas de 1970 e 1980 , cujos objetos se articulavam em trono do samba carioca. ${ }^{395}$ Um outro exemplo bastante significativo é o arquivo de Miguel Ângelo de Azevedo (Nirez), oficialmente Museu Cearense da Comunicação, na cidade de Fortaleza, que reúne importante documentação, fruto de empenho particular do pesquisador, organizado em mais de 50 anos de dedicação pessoal. Possui um acervo de mais de 100 mil peças, dentre elas uma coleção de 22 mil discos 78 rpm. Os discos foram digitalizados recentemente e catalogados em banco de dados disponibilizado para consulta. Nirez participou conjuntamente com Grácio Guerreiro Barbalho, Alcino de Oliveira Santos e Jairo Severiano da edição da Discografia brasileira em 78rpm, 1902-1964, publicada pela FUNARTE em 1982. 0 arquivo Nirez foi suporte importante na pesquisa de João Ernani Furtado Filho.

Mas além do fato de que estes acervos felizmente existentes refletem as posturas daqueles pesquisadores que os organizaram, uma outra questão é como são trabalhadas as documentações existentes. Ou seja, se a composição destes acervos já passou pela triagem inicial de seus colecionadores, como aliás ocorre com qualquer acervo ou museu, pode ocorrer uma segunda triagem, que seria a utilização do acervo para localizar aquelas fontes e documentos que já se tornaram canônicas em narrativas

\footnotetext{
394 MIS-RJ. As vozes desassombradas do museu. Rio de Janeiro, Ed. MIS-RJ, 1970.

395 Alguns dos trabalhos que citam este livro são: PEREIRA, Maria Helena Gisela Ferrari Gomes. Samba: do lazer aos mass media. Dissertação de mestrado em Comunicação. Rio de Janeiro: UFRJ, 1979; MATOS, Cláudia Neiva de. $O$ malandro no samba: uma linguagem de fronteira. Dissertação de mestrado em Letras. Rio de Janeiro. PUC-Rio, 1981; CALDEIRA NETO, Jorge dos Santos. Voz macia: o samba como padrão de música popular brasileira - 1917/1939. Dissertação de mestrado em Sociologia. São Paulo: FFLCH-USP, 1989; SALVADORI, Maria Ângela Borges. Capoeiras e malandros: pedaços de uma sonora tradição popular (1890-1950). Dissertação de mestrado em História. Campinas: IFCH-UNICAMP, 1990.
} 
anteriores. ${ }^{396}$ Para dar um exemplo, na historiografia do samba, vamos considerar o lugar ocupado pela canção Lenço no pescoço, de Wilson Batista, e as demais que se seguiram na afamada polêmica com Noel Rosa. Esta canção é, por vezes, tida como um "hino da malandragem", quase um manifesto em defesa de um estilo de vida. É certo que apresenta uma descrição interessante do estereótipo do personagem malandro. Mas parece que existe um exagero em sua onipresença nos estudos em torno do samba, tanto na área de História como em outras disciplinas, especialmente Letras. Podemos nos perguntar se esta polêmica teve mesmo essa repercussão do ponto de vista da recepção (não conheço nenhum estudo a esse respeito) ${ }^{397}$, ou, se sua importância foi construída nos estudos do samba, tendo ela assim mais significação para os intelectuais do que para o público em geral.

Enfim, a questão para se pensar é a da seleção das fontes no processo da pesquisa. Uma pista interessante, por exemplo, é o caminho que Tiago de Melo Gomes afirma ter seguido para reunir a discografia de seu estudo sobre o personagem malandro, no qual, diga-se de passagem, colocou o título de Lenço no pescoço:

É necessário lembrar que neste ponto houve a preocupação de reunir um acervo pessoal de canções do período com dimensões que permitissem uma boa idéia do panorama musical sem que houvesse a dependência das canções citadas por outros estudiosos do assunto ou das coleções lançadas recentemente pelas gravadoras. As canções selecionadas e citadas no trabalho

\footnotetext{
396 Um exemplo de seleção de repertório e construção da memória é a coleção de discos em vinil chamada História da Música Popular Brasileira lançada pela Abril Cultural na década de 1970. Os discos traziam gravações selecionadas de compositores considerados relevantes para uma história da música popular e vinham acompanhados de textos sobre a vida e a obra do autor retratado. Os fascículos semanais da coleção eram vendidos em bancas de jornal a um preço acessível. Fez um grande sucesso tendo vendido mais de 7 milhões de exemplares em três edições. A série contribuiu fortemente, pela sua popularidade, na construção de uma memória da música popular no Brasil. A coleção já instituía um cânone de quais os grandes compositores dignos de figurar numa história da música popular no Brasil na própria organização da coleção. Considere-se que a série incluía artistas muito jovens, que tinham despontado no cenário em meados da década anterior, como Chico Buarque, Caetano Veloso, Gilberto Gil e Paulinho da Viola, ao lado de outros nomes de gerações anteriores, como Noel Rosa e Pixinguinha; mais do que isso, mesmo entre estes compositores selecionados, a coleção indicava, na seleção das músicas que comporiam o fascículo, quais as principais canções da obra destes compositores, criando assim também um cânone interno a obra de cada um dos artistas retratados. Estabelecia assim, um cânone de compositores e obras. Está claro que toda coleção deste tipo ou similar, coletâneas da obra de determinado artista, dicionário enciclopédico de música ou mais recentemente, sites na Internet, sempre tendem a propor um cânone de autores ou obras. Mas no caso de História da Música Popular Brasileira lançada pela Editora Abril, isto foi potencializado por sua enorme popularidade, num momento de valorização da MPB e ascensão da canção popular ao status de produto artístico, somado à ampla rede de distribuição e a facilidade de acesso para um público jovem de classe média que se incorporava ao consumo de música popular brasileira. Ver STROUD, Sean. Disco é cultura: MPB and the defense of tradition in Brazilian popular music. PhD Thesis. University of London. 2005, pp.80-81.

397 Em A canção no tempo, Lenço do Pescoço não é mencionada no ano de seu lançamento, 1933. A canção vai aparecer apenas para ilustrar o verbete de Palpite Infeliz, de Noel Rosa, de 1935. Segundo os autores, em 1935 Wilson Batista era um jovem compositor que lutava para aparecer no meio musical. MELLO, Zuza Homem de. SEVERIANO, Jairo. A canção no tempo: 85 anos de músicas brasileiras. vol.1 (1901-1957). São Paulo: Editora 34, 1997, p. 147.
} 
não foram recolhidas de outros trabalhos, portanto, mas do acervo particular deste autor, que soma razoável quantidade de canções do período, além de outros períodos que por algum motivo tiveram alguma composição citada. Há ainda as composições retiradas dos textos das peças de teatro de revista, casos estes explicitados no texto desta dissertação. Neste caso, são canções as quais apenas as letras foram analisadas, pois não se conhece suas melodias. ${ }^{398}$

Outra parte importante do acervo documental é composta por escritos de memorialistas e jornalistas, contemporâneos aos acontecimentos. Conforme foi discutido no Capítulo 1, os primeiros textos disponíveis sobre a música popular urbana foram obra de memorialistas, jornalistas, músicos e aficionados, entre eles os "clássicos" Choro, do Animal, na Roda do Samba, de Vagalume e Samba, de Orestes Barbosa, textos que inauguram uma literatura e iniciam a construção de uma "tradição" da música carioca que seria elevada à condição de música popular brasileira. Estes textos fundadores foram relançados pela FUNARTE em 1978 como parte de um boom de publicações em torno da música popular carioca no final dos anos 1970 e começo dos anos 1980, sob a coordenação de Hermínio Bello de Carvalho, que contribuíram para a fixação de uma certa tradição da música popular brasileira, questão também abordada no Capítulo 1. Falando sobre esta corrente historiográfica, que denomina de "primeira geração de historiadores da música popular urbana no Brasil", Vinci de Moraes afirma:

As obras destes cronistas continuam formando acervo documental importante
e precioso para a memória da cultura musical do país. Por isso, eles - e os
cronistas da geração imediatamente posterior também - ainda são tratados
pelos atuais pesquisadores da música popular como fontes primárias e
"fidedignas," as quais servem de suporte documental básico e dão autoridade
às investigações mais recentes. Porém, já é tempo de compreendê-los de outra
maneira, alargando e diversificando os horizontes de análise e de crítica. ${ }^{399}$

A obra desta primeira geração de historiadores, e de outras que os seguiram, constituem "acervo documental importante e precioso", como disse Vinci de Moraes, e, portanto, não podem ser desconsideradas em estudos sobre a música popular nos primeiros ano do século XX no Rio de Janeiro. A questão é como trabalhar com estes documentos, uma vez que estes autores não eram observadores imparciais. Eram

\footnotetext{
398 GOMES, Tiago de Melo. Lenço no pescoço: o malandro no teatro de revista e na música popular - "nacional", "popular" e cultura de massas nos anos 1920. Dissertação de mestrado em História. IFCH-UNICAMP, 1998, p. 9.

399 MORAES, José Geraldo Vinci de. Sons e música na oficina da História. In: Revista de História. Departamento de História da FFLCH-USP. São Paulo: Humanitas /FFLCH-USP, no 157, 2007, pp. 7-13.
} 
pessoas ligadas ao meio musical, profissionalmente ou por afinidade, e seus textos eram dedicados à apologia da música carioca com a qual conviviam intensamente. Estes textos têm importância pelos dados que apresentam - que precisam ser sempre submetidos à critica, como todos os documentos - mas também pelo discurso dos autores, pela narrativa em si mesma. Ou seja, esse discurso é, em si, uma fonte histórica, na medida em que indica um forma de pensar, uma leitura do processo em curso, construída por setores mais letrados do próprio meio musical, como parte de um processo de construção de uma tradição.

A partir dos anos 1960, existe um salto de qualidade na obra de herdeiros e continuadores desta corrente historiográfica, como Ary Vasconcelos, Tinhorão, Sérgio Cabral e Jairo Severiano. Os trabalhos destes pesquisadores também são citados abundantemente, sendo José Ramos Tinhorão o campeão absoluto de citações em pesquisas acadêmicas sobre a música popular urbana no Brasil. Nenhum outro autor é tão mencionado como ele, o que é compreensível, dada a dimensão, qualidade e alcance de sua obra. Entretanto, existem, alguns exageros e, em muitos casos, seria adequado ir mais próximo da fonte primária. Por exemplo, a citação dos manuscritos da Biblioteca da Ajuda a partir de Tinhorão. Estes textos, importante descoberta musicológica, cuja existência foi revelada por Gerard Béhague em artigo publicado em 1968, foram objeto de estudo acadêmico em 1998 e estão disponíveis em publicação bem documentada de Edilson de Lima desde 2001, conforme observado no início deste capítulo. Embora neste caso se possa chegar mais perto da fonte primária (o fac-símile e transcrição dos manuscritos) sem precisar ir à Portugal, por outro lado, naturalmente, é honesto dizer que se chegou a ela pela leitura de Tinhorão, embora Tinhorão também tenha chegado a eles por outras leituras.

Além dos memorialistas que escreveram diretamente sobre a música popular de sua época, outros escritores se dedicaram a retratar a vida urbana, as questões sociais e culturais em pauta, bem como as transformações em curso na sociedade. De especial interesse são as narrativas sobre a cidade do Rio de Janeiro, bastante citadas quando o assunto é o período denominado como Belle Époque carioca ou Belle Époque tropical. Entre os textos mais mencionados, encontram-se $O$ Rio de Janeiro de meu tempo, do jornalista e escritor carioca Luis Edmundo (1878-1961) e A Alma Encantadora das 
Ruas, do também jornalista e escritor João do Rio, pseudônimo de João Paulo Emílio Cristóvão dos Santos Coelho Barreto (1881-1921).400

Embora não tenha aparecido de maneira sistemática nos trabalhos que analisamos, em função dos objetos e periodizações, a literatura sempre se constituiu numa fonte importante para o estudo da música no Brasil, desde os diários dos viajantes estrangeiros, que oferecem informações importantes sobre o Brasil Colônia, ou melhor, desde a Carta de Pero Vaz de Caminha ${ }^{401}$. 0 texto mais emblemático da literatura brasileira a abordar um tema musical é o conto de Machado de Assis, Um homem célebre. Este conto, publicado pela primeira vez em 1888 e ambientado em 1875, é a história do pianista e compositor Pestana, que, famoso e reconhecido pelas suas polcas, era frustrado por não conseguir compor no estilo dos mestres europeus que ele tanto admirava. 0 texto, magistralmente escrito com a leveza e fina ironia machadiana, apresenta uma percepção refinada de questões que estariam no centro da história da música brasileira, a dicotomia entre o erudito e o popular e entre produção nacional e influências estrangeiras, conforme discutido ao longo desta tese. ${ }^{402}$

Muitos trabalhos recorrem a fontes orais e de memória, seja através de depoimentos disponíveis ou de entrevistas originais. Entre os depoimentos clássicos, estão aqueles feitos para o Museu da Imagem e do Som do Rio de Janeiro, particularmente os publicados no livro As vozes desassombradas do Museu. Outra

\footnotetext{
400 EDMUNDO, Luis. O Rio de Janeiro de meu tempo. Brasília: Edições do Senado Federal, 2003; JOÃo DO RIO. A alma encantadora das ruas. Fundação Biblioteca Nacional. Ambos disponíveis em <www.dominiopublico.gov.br>. A música na Belle Époque no Rio de Janeiro já havia sido tema do livro Panorama da Música Popular Brasileira na Belle Époque, de Ary Vasconcelos (1977). Sobre o período Jeffrey D. Needeli publicou em 1988 A Tropical Belle Epoque: elite culture and society in turn-of-the-century Rio de Janeiro, lançado no Brasil em 1993 pela Companhia das Letras como Belle Époque Tropical: sociedade e cultura de elite no Rio de Janeiro na virada do século, texto que foi citado em diversas pesquisas.

$401 \mathrm{Na}$ Carta a El Rey Dom Manuel, encontram-se breves passagens onde se identificam práticas musicais nos primeiros contatos entre portugueses e índios brasileiros: "E depois de acabada a missa, quando nós sentados atendíamos a pregação, levantaram-se muitos deles e tangeram corno ou buzina e começaram a saltar e dançar um pedaço”; (...) “Passou-se então para a outra banda do rio Diogo Dias, que fora almoxarife de Sacavém, o qual é homem gracioso e de prazer. E levou consigo um gaiteiro nosso com sua gaita. E meteu-se a dançar com eles, tomando-os pelas mãos; e eles folgavam e riam e andavam com ele muito bem ao som da gaita." CAMINHA, Pero Vaz de. Carta $a$ El Rei D. Manuel. São Paulo: Dominus, 1963.

402 ASSIS, Machado de. Um homem célebre. Publicado originalmente na Gazeta de Notícias em 1888 e republicado em Várias Histórias, Rio de Janeiro: Laemmert \& C. Ed., 1896. Dois textos foram articulados em torno do conto de Machado de Assis, conforme explicitado nos títulos: WISNIK, José Miguel. Machado maxixe: o caso Pestana. In: Teresa. São Paulo: Editora 34, no 4 e 5, 2003 e MACHADO, Cacá. O enigma do homem célebre: ambição e vocação de Ernesto Nazareth (1863-1934) - música, história e literatura. Tese de doutorado em Letras. São Paulo, FFLCH-USP, 2005. O conto também está presente, entre outros, em: AUGUSTO, Paulo Roberto Peloso. Tangos brasileiros, Rio de Janeiro: 1870 / 1920. Tese de doutorado em História. São Paulo: FFLCH-USP, 1996 e ESTEPHAN, Sérgio. O violão instrumental brasileiro: 1884-1924. Dissertação de mestrado em História. São Paulo: PUC-SP, 1999; FERNANDES, Dmitri Cerboncini. A inteligência da música popular: a "autenticidade" no samba e no choro. Tese de doutorado em Sociologia. São Paulo: FFLCH-USP, 2010.
} 
entrevista muito mencionada é a realizada por Sérgio Cabral com Ismael Silva e Donga, ${ }^{403}$ em que se encontra a célebre discordância na caracterização do samba entre estes sambistas de distintas gerações (Ismael considera maxixe o que Donga entende por samba; Donga considera marcha o que é samba para Ismael) e a também famosa e impagável expressão de Ismael Silva bumbum paticumdumprugurundum.

Se, para o estudo do samba na primeira metade do século $\mathrm{XX}$, este é um material fundamental, trabalhos focados em outros objetos e periodizações têm se utilizado de entrevistas originais com músicos, parentes, amigos, aficionados e pessoas que conviveram de alguma forma com o tema do estudo e suas circunstâncias. Trabalhos sobre a memória, naturalmente, vão se utilizar mais deste expediente metodológico. Este é o caso dos trabalhos de Alcir Lenharo, Carlos Drehmer, Raimundo Costa Silva e Paulo César Araujo, entre outros. Dependendo do objeto da pesquisa, as entrevistas são essenciais, fontes de informações por vezes inacessíveis de outra forma, permitem perceber o pensamento de personagens relevantes ou opiniões sobre eles. São também geralmente agradáveis como leitura, tornando o texto mais leve, quando bem articuladas com o curso da narrativa. Mas, em algumas situações, as entrevistas ultrapassam a definição da memória e da identidade dos protagonistas, para serem utilizadas como ponte para a realidade histórica. Por vezes sentimos a falta de uma crítica desse material, sendo as declarações tomadas como fonte fidedigna, especialmente quando vão ao encontro da linha de raciocínio que o autor vem desenvolvendo. Por exemplo, os depoimentos, assim como citações de jornalistas e memorialistas, são tomados por Antonio Gomes da Silva como fontes confiáveis e fidedignas e sua narrativa fica pautada nestes textos e entrevistas, sem conferência dos dados, redundando na construção apologética da imagem de Luiz Gonzaga. Também Paulo César Araújo, em seu instigante trabalho, no qual seus famosos entrevistados por vezes manifestam nunca terem sido abordados a respeito das questões da pesquisa, por vezes prescinde de uma crítica objetiva aos depoimentos de seus personagens.

\footnotetext{
403 CABRAL, Sérgio. As Escolas de Samba do Rio de Janeiro. Rio de Janeiro: Lumiar, 1996. Este livro ampliou e atualizou um estudo anterior do autor lançado cerca de 23 anos antes: As Escolas de Samba: o que, quem, como, quando e por quê. Rio de Janeiro: Editora Fontana, 1974.
} 


\section{CAPÍTULO 6 \\ HISTÓRIA DA MÚSICA OU MÚSICA NA HISTÓRIA?}

Este capítulo está dedicado ao estudo de algumas questões metodológicas fundamentais para uma historiografia da música popular a partir da análise das dissertações e teses em foco neste trabalho, combinada com algumas considerações teóricas acerca da história da música. Num primeiro momento, irei observar a relação da história com as musicologias, uma vez que não se pode pensar a história da música sem considerar as disciplinas mais diretamente voltadas para o estudo da música. A abordagem musicológica é uma tendência para a relação história, música e sociedade que os trabalhos historiográficos, com algumas exceções, pouco seguiram, ao menos dentro do nosso recorte cronológico. Irei assim, para utilizar uma expressão musical, tratá-la como um contraponto ${ }^{404}$ para esta historiografia.

Este capítulo estará dividido em 5 partes. 0 item 6.1 apresenta um breve histórico das musicologias, destacando como seus objetos, teorias e métodos pautaram o processo de institucionalização do campo (neste item, explicarei o porquê do termo aparecer no plural). 0 objetivo deste histórico é oferecer alguns elementos para a compreensão da dinâmica atual das discussões metodológicas no campo musicológico. No item 6.2, serão apresentadas algumas reflexões acerca da interação entre "história da música" e "música como documentação historiográfica", uma interseção que certamente está presente na expressão atualmente corrente História e Música. ${ }^{405}$ No item 6.3, se observará a repercussão nos primeiros trabalhos historiográficos da metodologia desenvolvida na área de Letras para a abordagem da canção, baseada no plano discursivo do texto literário. A seguir, no item 6.4, serão desenvolvidas algumas

\footnotetext{
404 O Oxford Dictionary of Music inicia seu verbete sobre o contraponto com esta interessante observação: "A capacidade, exclusiva da música para dizer duas coisas ao mesmo tempo de maneira compreensível". 0 termo foi utilizado pela primeira vez no século XIV para descrever a combinação de linhas musicais simultâneas de acordo com um sistema de regras. Deriva da expressão punctus contra punctum, ponto contra ponto, ou seja, "nota contra nota". O uso corrente mais comum da palavra é a da combinação de partes (vozes) simultâneas, cada uma delas tendo significado em si e sua combinação resultando em uma textura coerente, tendo nesse sentido o mesmo significado que polifonia. A arte do contraponto foi desenvolvida gradualmente do século IX em diante e chegou ao seu ponto mais alto no final do século XVI e início do XVII. In: OXFORD MUSIC ONLINE. Oxford University Press. 405 NAPOLITANO, Marcos. História \& música: história cultural da música popular. Belo Horizonte, Autêntica, 2002; MORAES, José Geraldo Vinci de; SALIBA, Elias Thomé (orgs.). História e Música no Brasil. São Paulo: Alameda, 2010. Também as mesas temáticas História \& Música popular em eventos da ANPUH, que vem sendo coordenadas por Adalberto Paranhos e Tânia da Costa Garcia. Mas o caso mais emblemático é o da Escola de Música da UFMG, que a partir da reformulação curricular ocorrida há cerca de 10 anos, renomeou a disciplina histórica como História e Música, para explicitar a ruptura radical do projeto com as concepções tradicionais da história da música.
} 
reflexões acerca das relações entre análise técnico-estética da música e abordagens histórico-sociológicas, destacando que a partir da superação da metodologia baseada na análise das letras das canções, duas vertentes se apresentaram: uma historiografia que se desenvolvia sem incorporar o estudo da linguagem musical e as vertentes que procuram, em diferentes planos, incorporar os aspectos sonoros. Por último, o item 6.5 está dedicado à reflexão acerca das tensões entre a produção historiográfica, os estudos sobre a música popular e as musicologias. A argumentação desenvolvida ao longo do capítulo propõe considerar complementares as distintas abordagens, uma vez que reconhece a impossibilidade de uma história da música universal e totalizante, e pontua a dificuldade de separar a discussão puramente epistemológica das disputas de competências e legitimidades inerentes ao campo científico.

\subsection{A CONSTITUIÇÃO DO CAMPO MUSICOLÓGICO: OS SIGNIFICADOS DE “MUSICOLOGIA” E O PREFIXO “ETNO”}

O termo "musicologia", que denomina (ou deveria denominar) a disciplina de estudos científicos da música, contém uma ambiguidade. Ele é, por vezes, empregado no sentido de um amplo campo interdisciplinar de estudos da música, enquanto texto e contexto, no qual os músicos seriam os especialistas nas questões relativas ao material sonoro propriamente dito. Por outro lado, a Musicologia como disciplina acadêmica acabou historicamente associada, ao menos até por volta dos anos 1980, a apenas um dos seus ramos originais, a Musicologia Histórica.

Nas suas origens, a Musicologia estava mais próxima da visão ampla. 0 termo alemão Musikwissenschaft, ciência da música, denominava a pesquisa científica da música sobre todos os aspectos, como se depreende da clássica estruturação da disciplina proposta por Guido Adler. Na introdução de seu polêmico e influente livro Contemplating Music: challenges to Musicology, lançado no Brasil com o título de Musicologia, 406 Joseph Kerman discute esta questão da significação do termo. Segundo ele, na prática acadêmica e no uso geral, musicologia passou a ter um significado muito mais restrito, referindo-se ao estudo da história da música ocidental na tradição de

406 KERMAN, Joseph. Musicologia. Coleção Opus-86. São Paulo: Martins Fontes, 1987. Titulo original Contemplating music: challenges to Musicology, 1985. 
uma arte superior. Segundo Kerman, para muitos acadêmicos a musicologia é restrita não só quanto ao objeto de estudo que abrange, mas também quanto à abordagem desse objeto. E a seguir ele recoloca a questão: "Qual o tema deste livro - a musicologia na definição ideal, abrangente, original, ou a musicologia em sua definição atual, restrita e mais comum? A ampla ou a estreita? A resposta situa-se em algum ponto entre esses dois pólos." Aprendemos assim que ainda existem gradações entre estas concepções extremadas de musicologia que, segundo o autor, correspondem "a duas concepções sobre o assunto que determinam o trabalho dos estudiosos atuais" 407

Esta identificação do termo musicologia com apenas um dos ramos do amplo campo de estudos da música tem sido apontada por diversos autores. Nicholas Cook, em Agora somos todos (Etno)musicólogos, esclarece que nesse artigo está utilizando o termo musicologia num sentido restrito, isto é, “o estudo histórico da tradição 'artística' ocidental" 408 e cita Gilbert Chase, para quem "musicologia, sem nenhum qualificador, foi tacitamente apropriada pela filial histórica dessa disciplina"409. Esta apropriação do termo musicologia e a ocupação do campo institucionalizado da disciplina por um dos ramos da "ciência da música", as concepções estéticas e ideológicas que fundamentavam estas posições, além das diferenças de objeto de estudo e metodologias, estiveram na raiz da organização da Etnomusicologia como um campo de estudos autônomo.

Embora o termo Etnomusicologia tenha sido empregado para designar um campo de estudos musicológicos apenas a partir da década de 1950, as origens desse campo remontam à década de $1880^{410}$. Durante a primeira metade do século $\mathrm{XX}, \mathrm{o}$ nome Musicologia Comparada foi utilizado, ainda que com reservas, pelos pesquisadores do campo. Em Definitions of “Comparative Musicology" and "Ethnomusicology": An Historical-theoretical perspective, 411 Merriam lista e discute diversas definições de Musicologia Comparada e de Etnomusicologia entre as que ele

\footnotetext{
407 KERMAN, Joseph. Musicologia. Coleção Opus-86. São Paulo: Martins Fontes, 1987, pp. 1-13.

408 COOK, Nicholas. Agora somos todos (etno)musicólogos. Título original: We are all (Ethno)musicologists now. Ictus- UFBA, n.7, 2006, p. 8. Tradução de Pablo Sotuyo Blanco.

409 Ibidem, p. 28.

410 Para Bruno Nettl (1995), se em relação à Musicologia é discutível o momento do seu surgimento, é difícil situar o nascimento da Etnomusicologia em outra década que não a de 1880. Mas parece que a questão não é tão pacífica assim. Charles Seeger (1961) e Tiago de Oliveira Pinto (2004) preferem situar esse nascimento no início do século $\mathrm{XX}$.

411 MERRIAM, Alan. Definitions of "Comparative Musicology" and "Ethnomusicology": An Historical-Theoretical Perspective. Ethnomusicology, v.21, n.2, pp. 189-204, 1977.
} 
considerou mais importantes e representativas, desde a primeira de Guido Adler em 1885 até o momento da redação do artigo. De uma maneira geral, as distintas definições de Musicologia Comparada ressaltavam os mesmos pontos e definiam o campo em termos do seu objeto de estudo: músicas não ocidentais, por vezes designadas "exóticas", ou músicas de tradições orais.

É unanimemente aceito que a primeira vez que o termo Etnomusicologia apareceu impresso foi em 1950 no subtítulo do livro de Jaap Kunst Musicologica, rebatizado nas edições posteriores como Ethnomusicology, ${ }^{412}$ mas Merriam faz a ressalva de que a palavra já estava em uso corrente entre os pesquisadores no momento. Em 1955, foi fundada nos Estados Unidos, como sucessora da American Society for Comparative Musicology que teve curta existência nos anos 1930, a Society for Ethnomusicology - SEM ${ }^{413}$, que viria a ser uma poderosa e influente instituição. 0 termo Etnomusicologia foi aceito quase imediatamente. Durante alguns anos, ambas as denominações foram utilizadas simultaneamente e, pelo final da década de 1950, Musicologia Comparada estava reduzida a uma expressão histórica, que remetia ao passado do campo.

A mudança de nome de todo um campo de estudos, combinada com sua ansiosa e imediata aceitação, não é um evento para ser desconsiderado facilmente, como ressalta Merriam. ${ }^{414}$ Ele vê esse evento como um indicativo de um forte desejo de mudança que certamente não se restringia à questão terminológica. Para Philip Bohlman, a Etnomusicologia, nos anos 1950, voltava-se não apenas contra as concepções estético-ideológicas que dominavam a corrente principal da Musicologia, mas também contra concepções de comparativistas que atuavam tendo como referência a música da tradição europeia. ${ }^{415}$

O celebrado livro de Alan Merriam, The anthropology of music, no qual ele propõe um modelo para as pesquisas etnomusicológicas a partir do encontro da antropologia com a musicologia, e sua clássica definição para Etnomusicologia como $o$

412 KUNST, Jaap. Ethnomusicology. 3ạ ed. Netherlands: The Hague Martinus Nijhoff, 1959. Título da 1aㅡ edição, de 1950: Musicologica: a study of the nature of ethno-musicology, its problems, methods and representative personalities. A partir da 2a edição expandida, de 1950, o livro foi rebatizado para Etnomusicology.

${ }^{413} \mathrm{Um}$ breve relato sobre a fundação da SEM pode ser encontrado em artigo de seu primeiro presidente, Willard Rhodes, A short history of the founding of SEM, 1980, disponível no site da SEM na internet.

414 MERRIAM, Alan, P. The anthropology of music. Northwestern University Press, 1964. Este texto clássico encontrase entre aquelas obras fundamentais que infelizmente ainda não encontraram tradução para o português.

415 BOHLMAN, Philip. Ethnomusicology's Challenge to the Canon; the Canon's Challenge to Ethnomusicology. In: BERGERON; BOHLMAN (eds.) Disciplining Music: musicology and its canons. The University of Chicago Press, 1992, p.119-122. 
estudo da música na cultura são ilustrativos dessas transformações. Esta sintética formulação enfatizava que o tipo de música a ser estudado não era (ou não deveria ser) mais central, e sim o processo, o modo como essa música seria estudada. Mas esta fusão metodológica da musicologia com a antropologia nunca chegou a um equilíbrio perfeito, pendendo mais para um lado ou para outro, conforme a formação profissional, as concepções e atitudes do pesquisador. Nas palavras de Merriam, o etnomusicólogo antropológico vê o som da música, mas como uma parte de um complexo de atividades, conceituações e comportamentos relacionados com a música, enquanto o etnomusicólogo musicológico vê o som da música como foco preciso da sua atenção. ${ }^{416}$ Observe-se que esta formulação de Merriam acerca da fusão metodológica das disciplinas constitutivas da etnomusicologia, naquele momento da constituição do campo, aplica-se perfeitamente ao estado da arte da história da música ou das relações entre História e Música a partir da atualização destas disciplinas propostas pela História renovada e pela Musicologia informada pelas discussões propostas pela Etnomusicologia. Retornarei a este ponto ao final desta reflexão sobre a constituição do campo musicológico.

É preciso considerar também as diferenciações de objeto. A opção pela música artística europeia como objeto de estudo não pode ser reduzida a uma questão ideológica ou de fruição estética. Trata-se de um patrimônio da humanidade, objeto legítimo de estudo, como também o são outras músicas. Por outro lado, a escolha de músicas não ocidentais ou de tradição oral como objeto de estudo, caso dos objetos privilegiados dos primeiros etnomusicólogos, mesmo considerando-se todas as teorizações ancoradas na Antropologia que sustentam essa decisão, são também uma opção do pesquisador.

A diferença sob vários pontos de vista entre os objetos de estudo levou a que os campos em formação se utilizassem de um instrumental teórico igualmente diferenciado. Enquanto o estudo histórico da música ocidental tinha ligações com a historiografia, ainda que sem a concorrência de historiadores de ofício, a Etnomusicologia ligou-se às teorias e métodos da Antropologia. Mas um agravante nesta separação metodológica é que, por volta da década de 1950, o ramo histórico da Musicologia estava completamente defasado em relação às novas concepções teóricas e 
metodológicas da História que se desenvolviam tanto entre os Annales como nos escritos em língua inglesa. A historiografia da música que, em geral, era feita por musicólogos historiadores e não por historiadores de ofício, era factual, cronológica, biográfica e evolucionista. Era a história das grandes obras e dos grandes gênios da música. Kerman afirma que "ler sobre a musicologia da década de 50 é experimentar uma distorção no tempo". Ele considerou notável como as palavras escritas por Collingwood acerca da historiografia positivista alemã no século XIX se enquadravam perfeitamente na situação musical 75 anos depois. ${ }^{417}$ É evidente que o estudo das músicas não-ocidentais não poderia florescer em tal quadro teórico metodológico. Os pesquisadores interessados nesse objeto encontraram novos ares na Antropologia. A mudança abrupta do nome do campo - evento raro e significativo - simbolizou essa aliança. Bohlman considera difícil de aceitar como coincidência o fato de que o nome remeta a um movimento na Antropologia dos anos 50, chamado Nova Etnografia, e à proliferação de subdisciplinas como etnolinguística, etnohistória e etnomusicologia. 0 autor também ressalta que este momento de reciclagem e rebatismo do campo dependeu de condições históricas obtidas em um lugar determinado, os Estados Unidos da América. Além da migração de pesquisadores experientes como decorrência da II Guerra Mundial, o campo foi também oxigenado pelo papel central da Antropologia nos Estudos Unidos. Assim, a Etnomusicologia logo encontrou suporte institucional na universidade estadunidense. ${ }^{418}$

Nas bases do "cisma musicológico dos anos 50" estão questões estéticoideológicas, diferenças expressivas de objeto de estudo, distintas concepções metodológicas e aspectos históricos da institucionalização do campo. Nos Estados Unidos existe ainda, como um subcampo dos estudos musicais, o da teoria, que está institucionalizado na Society for Music Theory. Costuma-se dizer que os estudos musicais estão divididos em Musicologia Histórica, Etnomusicologia e Teoria Musical (também chamado de Sistemática), que corresponde à forma como a musicologia está dividida nos Estados Unidos. Em outros países não se reproduzem necessariamente estas subdivisões, e, no caso do Brasil, as fronteiras entre os ramos musicológicos

\footnotetext{
417 KERMAN, Joseph. Musicologia. Coleção Opus-86. São Paulo: Martins Fontes, 1987. Titulo original Contemplating music: challenges to Musicology, 1985, pp. 48-49.

418 BOHLMAN, Philip. Ethnomusicology's Challenge to the Canon; the Canon's Challenge to Ethnomusicology. In: BERGERON; BOHLMAN (eds.) Disciplining Music. The University of Chicago Press, 1992, pp. 122-129.
} 
felizmente não são muito rígidas. Mas poderíamos nos perguntar, nesta subdivisão, que é sempre mencionada, ou outra classificações similares, como se situam os estudos sobre música popular?

Um bom exemplo da dificuldade da classificação dos estudos musicais nas circunstâncias atuais é a forma como Carlos Sandroni situa o seu trabalho Feitiço Decente: transformações do samba no Rio de Janeiro (1917-1933):

Talvez o que o leitor tem em mãos possa se definir como um trabalho de "etnomusicologia histórica". De fato, seu objeto é a música popular, que na divisão universitária do trabalho tem sido reservada à etnomusicologia. Se, entretanto, considerarmos que esta última se caracteriza pela pesquisa de campo formalizada, numa cultura em relação à qual o pesquisador se situa como "estrangeiro", este trabalho não pode ser assim classificado. 0 fato de ter estudado músicas do passado e de ter dedicado, na Parte I, bastante espaço à análise de peças de música impressa contribuiria igualmente, segundo as etiquetas em vigor, para classificá-lo antes no domínio da musicologia. 419

É de se ressaltar que, após mostrar a dificuldade de situar o seu trabalho segundo as etiquetas vigentes, Sandroni segue afirmando que "esta discussão só interessa na medida em que contribui para atenuar a rigidez das fronteiras metodológicas" e que, no Brasil "a separação entre diferentes categorias musicais parece ser menos marcada que em outros países", sendo assim, na sua opinião, "compreensível e útil (...) que os estudos musicais brasileiros sigam o mesmo caminho". 420

É importante observar que, num primeiro momento, embora músicos estivessem evidentemente envolvidos, as pesquisas sobre música popular, tanto no Brasil como no plano internacional, não surgiram por dentro das musicologias então estabelecidas. Ao contrário do que ocorreu no caso da Etnomusicologia ou da Teoria Musical, o campo dos estudos da música popular não surgiu como um ramo da Musicologia, ou mesmo da própria Etnomusicologia, embora o objeto esteja também compreendido por estas disciplinas em suas linhas mais atualizadas. Tanto para aqueles que estavam voltados para a complexidade formal das construções da música artística europeia, como para os que estavam interessados na diversidade cultural produzida na longa duração, a moderna música urbana não era um objeto que

419 SANDRONI, Carlos. Feitiço decente: transformações no samba no Rio de Janeiro (1917-1933). Rio de Janeiro: Zahar / UFRJ, 2001, p. 16.

420 Ibidem, p.17. 
despertasse interesse, quando não considerada desprezível ou irrelevante. Em 1983, Philip Tagg, de maneira provocativa e bem humorada, propunha considerar, para efeito do debate sobre o papel da IASPM (International Association for the Study of Popular Music), música popular como toda a música tradicionalmente excluída dos conservatórios, escolas de música e departamentos de musicologia das universidades e geralmente excluída da educação e financiamentos públicos. ${ }^{421}$ Se felizmente tal "definição" está desatualizada, ela refletia a percepção dos pesquisadores do campo acerca do espaço existente naquele momento dentro da Musicologia institucionalizada.

Desde os trabalhos pioneiros, os estudos sobre a música popular vêm se constituindo num campo multidisciplinar. Talvez mais do que outras músicas, a música popular urbana ofereça elementos para pesquisas em áreas como Teoria Literária, Linguística, Semiótica, Comunicação e Psicologia Social, além, naturalmente, das musicologias e das áreas de História, Sociologia e Antropologia. Embora não houvesse unidade metodológica, os estudos sobre a música popular em diversas partes do mundo compartilhavam o fato de ser um "projeto" das áreas de humanidades e ciências sociais de uma maneira ampla, e a fundação da IASPM refletiu essa característica. Porém, esta afirmação do campo de estudos musical-popular como multidisciplinar não o diferencia necessariamente, apenas por este fato, da Musicologia e da Etnomusicologia, em suas concepções mais amplas. Para Nicholas Cook, assim como Bruno Nettl afirma que a Etnomusicologia não é uma disciplina, mas um campo que exige membros de outras áreas, o mesmo pode ser dito da Musicologia: "um empreendimento essencialmente multidisciplinar que agrupa historiadores, teóricos (que são para a música o que os linguistas são para os estudos literários), especialistas em culturas populares, e musicistas, dentre outros". ${ }^{422}$

Entretanto, se as características específicas da música popular, particularmente da canção popular, foram determinantes para torná-la objeto de interesse para distintas áreas, concorreram para a resistência inicial das musicologias em tomar a música popular como objeto de estudo questões estético-ideológicas, a inadequação do instrumental teórico-metodológico disponível, construído para o estudo de outros objetos, e o aspecto histórico-institucional.

\footnotetext{
421 TAGG, Philip. Why IASPM? Which tasks? Comunicação à 2a Conferência Internacional da IASPM, 1983. Popular Music Perspectives 2, pp.501-507, D. Horn (ed.), IASPM, Göteborg and Exeter, 1985.

422 COOK, Nicholas. Agora somos todos (etno)musicólogos. Título original: We are all (Ethno)musicologists now. Ictus- UFBA, n.7, 2006, p. 26.
} 
Do ponto de vista ideológico, as ligações intrínsecas e explícitas da música popular com o mercado afrontavam as concepções marxistas mais ortodoxas. 0 fato de esta produção ser em grande parte voltada para o entretenimento, para a dança e para o consumo no convívio social desagradava também os arautos da "alta cultura". As rápidas transformações e hibridismos característicos do meio urbano por sua vez provocavam a resistência dos defensores da "autenticidade". Foi muito difundida a visão da música popular como mercadoria "estandardizada" da "indústria cultural". 0 fato de que seus primeiros pesquisadores acadêmicos - e talvez também os que vieram depois - eram os já mencionados scholar-fans é um indicativo do peso das concepções estéticas neste processo de validação do objeto dentro do campo científico.

Embora a Musicologia e, antes dela, a Etnomusicologia estejam se reciclando e tornando-se disciplinas mais abertas ao diálogo recíproco e permeáveis às elaborações teóricas das chamadas "disciplinas auxiliares", por volta da década de 1970, elas ainda estavam presas aos cânones de objetos e teorias tradicionais de cada uma delas. Se no discurso, a Etnomusicologia se propunha a estudar todas as músicas do mundo, na prática muito pouca atenção era dada à moderna música urbana e mesmo à música artística europeia. Isso ocorria, segundo Richard Middleton, em parte porque outras disciplinas já se debruçaram sobre esses objetos, em parte porque os métodos e atitudes desenvolvidos ao longo da vida da disciplina não podem ser facilmente abandonados, mas principalmente devido ao que ele ironicamente considerou ainda produto da investigação colonial da burguesia ocidental, empenhada em preservar a música de outros povos antes que eles desapareçam e em documentar sobrevivências de práticas tradicionais, gozando nesse processo, o prazer do exotismo. ${ }^{423}$

A tendência à organização de um campo de estudos da música popular pode ser entendida, por um lado, como uma decorrência das circunstâncias da história da institucionalização dos estudos musicais, que privilegiaram outros objetos; por outro, como decorrências das próprias características e especificidades da música popular urbana: seu caráter massivo, mediatizado, sua instrumentação própria, a ênfase em parâmetros musicais não contemplados na notação tradicional, o papel da gravação como suporte, a relação semiótica texto e melodia nas canções, sua conexão com 
processos sociais e suas relações com o mercado. Estas questões impuseram ao campo o desenvolvimento de um instrumental teórico-metodológico - processo este ainda em curso - que vem se constituindo numa contribuição importante para os estudos musicais como um todo. Don Michael Randel aponta claramente esta questão:

\begin{abstract}
Os embates em torno do cânone musical se mostram mais claramente no domínio da música popular ocidental (a música que por qualquer medida quantitativa se sobrepõe a todos os outros tipos em nossa sociedade), do que no que diz respeito à música não-ocidental (que pode ser pensada como atrativa pelo exotismo) e ao jazz (que pode ser feito de maneira a funcionar como música ocidental). No caso da música popular, o instrumental tradicional da Musicologia parece destinado principalmente a continuar a manter a escória musical do lado de fora ao invés de ampliar o horizonte das nossas investigações. 0 estudo deste tipo de música requer um conjunto maior e mais variado de ferramentas. Mas algumas destas ferramentas irão também enriquecer o estudo dos nossos objetos mais tradicionais - incluindo alguns que temos admitido no nosso cânone sob falsos pretextos. ${ }^{424}$
\end{abstract}

Já mencionamos que existe um processo de reciclagem e convergência entre as musicologias no que diz respeito aos cânones de objetos e teorias. A Musicologia tem ampliado seu espectro de objetos sob pressões da produção erudita contemporânea, da música popular e das pesquisas etnomusicológicas. Vem também buscando atualizar seu instrumental teórico, procurando incorporar análises da música em seu contexto, o público, as questões da produção e recepção, como por exemplo, nos trabalhos do grupo que ficou conhecido como Nova Musicologia. E, antes disso, muitos etnomusicólogos já se debruçavam sobre um repertório fora do âmbito mais tradicional da disciplina, vinham ampliando seu instrumental teórico em direção às humanidades e ciências sociais, e questionando ícones como a posição de insider do pesquisador. Nos últimos 30 anos, estas questões epistemológicas e de organização do campo dos estudos da música vêm sendo muito discutidas, tendo para muitos um significativo impulso no livro seminal de Kerman. É certo que existe uma

\footnotetext{
424 RANDEL, Don Michael. The Canons in the Musicological Toolbox. In: BERGERON; BOHLMAN (eds.) Disciplining Music:. The University of Chicago Press, 1992, p.116-136. Tradução do autor: "The struggle over the canon shows itself most clearly not with respect to non-Western music (which may be thought of as attractively exotic) or jazz (which can be made to behave like Western art music), but in the domain of Western popular music - the music that by any quantitative measure overwhelms all other kinds in our society. Here the traditional Musicological Toolbox seems destined primarily to continue to keep the musical riff-raff out rather than to broaden the horizon of our investigations. The study of this kind of music will require a bigger and more varied set of tools. But some of these tools will enrich the study of our more traditional subjects, too - including some of the subjects that we have admitted to our canon under false pretenses."
} 
movimentação no campo e que muitas convicções têm sido demolidas. ${ }^{425}$ Mas existem também arestas a serem aparadas neste processo de aproximação dos estudos musicais, e não está clara qual será a dinâmica das discussões futuras e tampouco se deve esperar que este seja um processo linear. Por exemplo, no Brasil, a recente fundação da ABET (Associação Brasileira de Etnomusicologia) vai em sentido contrário a uma suposta tendência à convergência entre as musicologias.

\subsection{HISTÓRIAS DA MÚSICA E INTERSEÇÕES HISTÓRIA \& MÚSICA}

Podemos nos perguntar se o conjunto desta historiografia constitui uma história da música ou se constitui uma produção historiográfica que utiliza a música como fonte privilegiada de pesquisa histórica que, através da música, intenta pensar a sociedade, a política e os costumes, considerando a música como uma parte da constituição de determinado contexto histórico, aspecto através da qual se pode pensar o todo.

Inicialmente, não é uma coisa banal e pacífica definir o que é história da música e qual o seu objeto. Poder-se-ia inclusive colocar algumas complexas questões preliminares, como por exemplo, o que é música, tema que será evitado, prudentemente. Outra questão polêmica seria se existe ou é possível uma história da música em sentido pleno. Desde que se começou a incluir a palavra ocidental no título dos compêndios de história da música, já se assumia que se tratava de uma história de uma determinada tradição musical. Isso ocorreu no clássico A history of Western music, escrito originalmente por Donald Grout, revisto posteriormente por Claude Palisca e mais recentemente por Peter Burkholder. Segundo Palisca, “a inclusão da palavra ocidental no título reflete a consciência de que o sistema musical da Europa ocidental e das Américas é apenas um entre outros vários existentes na diversidade das civilizações mundiais", acrescentando a seguir que, dentro das "realizações musicais do Ocidente", o livro se atém àquilo que "costumamos chamar de música erudita". A seguir, Palisca vai afirmar que "a história da música é antes de mais a história do estilo musical e não pode ser compreendida sem um conhecimento em primeira mão da música em

425 Um panorama destas reflexões pode ser encontrado em: COOK; EVERIST. Rethinking music. Oxford University Press, 1999 e BERGERON; BOHLMAN (eds.) Disciplining music: musicology and its canons, University of Chicago Press, 1992. 
si". ${ }^{426}$ O livro de Grout e Palisca tem sido apontado como exemplo de uma concepção superada de história da música, em que pese seus méritos e mesmo grande utilidade como material de apoio para a disciplina. ${ }^{427}$ Para Lia Tomás, o livro é um exemplo de um tipo de compêndio que narra "aspectos gerais e cronológicos" numa perspectiva factual.

\begin{abstract}
Esses compêndios, com frequência narram aspectos gerais e cronológicos da historiografia musical e muitas vezes são marcadamente positivistas em sua metodologia. Em outras palavras, apresentam a história da música como uma sucessão de períodos históricos centrados em uma noção restrita de teoria enquanto 'técnica', o que acarreta uma descontextualização dos dados, uma limitação sobre o que se compreendia sobre teoria musical e por música em cada período. Esta sucessão histórica baseia-se em uma visão de superação, de melhoria e de aprimoramento e que torna sempre o tempo presente mais relevante do que seu anterior. ${ }^{428}$
\end{abstract}

De toda forma, trata-se de um olhar para a história da música, entre tantos outros possíveis. Por exemplo, o importante estudo de Enrico Fubini, La estética musical desde la Antigüedad hasta el siglo $X X,{ }^{429}$ é uma história da estética musical, que é também uma abordagem relevante para se compreender a história da música, embora também seja apenas uma parte dessa história e focada da mesma forma num determinado repertório.

Uma história da música centrada na técnica musical, na construção dos sistemas de estruturação da linguagem, é uma abordagem possível, importante e inclusive fascinante, ainda que não dê conta de toda a complexidade daquilo que se pode chamar de história da música. Não se trata de questionar a validade de uma história da técnica; o que se contrapõe é a idéia de que ela seria a história da música

\footnotetext{
426 GROUT, Donald; PALISCA, Claude. História da Música Ocidental. Título original: A History of Western Music, 1960. Tradução de Ana Luísa Faria. Lisboa: Gradiva Publicações, 1994, p. 9.

$427 \mathrm{Em}$ torno do livro foi organizado um sistema complementar que se ampliou ao longo do tempo e inclui atualmente uma antologia musical em partituras (Norton Anthology of Western Music), gravações destas partituras (Norton Recorded Anthology of Western Music, versão completa com 14 Cds e reduzida com 6 Cds) e um guia de estudo e escuta (Study and Listening Guide). Tornou-se assim um material fundamental para o estudo da história da música e contribuiu na mesma proporção de sua difusão para a consolidação e perpetuação do cânone musicológico. Após a revisão realizada na 7a edição por Peter Burkholder, a obra conta com mais um autor, uma vez que Grout e Palisca faleceram em 1987 e 2001, respectivamente. A revisão de Burkholder procura incorporar visões mais atualizadas da história da música. No prefácio da $8^{\underline{a}}$ edição, Burkholder afirma ter procurado trazer diversos temas para análise: as pessoas que criaram, executaram, ouviram e pagaram por essa música, as escolhas que elas fizeram e por que as fizeram, o que elas mais valorizavam na música e como essas escolhas refletiram tradição e inovação. Também se encontram menções à música popular, ao rap e ao jazz. O livro avançou bastante, e é um exemplo interessante de obra aberta e em progresso. Mas ainda mantém os problemas da estrutura da obra, característicos desse tipo de compêndio. GROUT; PALISCA; BURKHOLDER. A History of Western Music. 8th ed. New York: W.W. Norton \& Company, 2010. Infelizmente, a tradução em português permanece desatualizada.

428 TOMÁS, Lia Vera. Uma reflexão sobre a estética musical e a filosofia da música. Uberlândia: Revista ouvirOUver, vol. 1, no 5, 2009, p. 172.

429 FUBINI, Enrico. La estética musical desde la Antigüedad hasta el siglo XX. Madrid: Alianza Editorial, 1996. Títulos originais em italiano: L'estetica musicale dall'antichità al Settecento y L'estetica musicale dal Settecento a oggi, 1976.
} 
num sentido pleno. Esta maneira de pensar a história da música enquanto história da técnica está associada com a concepção estética da obra de arte como objeto autônomo, e é mais recorrente na história da música artística ocidental, na medida em que esta oferece mais elementos para esse tipo de abordagem, uma vez que parcela fundamental do repertório se constituiu a partir desta concepção estética. Mas também para a música popular urbana é válida uma história da técnica e dos sistemas de estruturação da linguagem, do ponto de vista rítmico, melódico e harmônico, ou, dizendo de outra maneira, para o caso do nosso estudo, uma história dos gêneros de música popular de um ponto de vista mais intrinsecamente musical. Essa linha de pensamento é, por vezes, adotada por músicos que enveredam por caminhos historiográficos, ainda que as linhas mais atualizadas da Musicologia ou da Etnomusicologia venham apontando suas limitações. É natural que uma abordagem histórica da estruturação da linguagem desperte o interessante dos músicos. Creio que é inclusive necessária como parte da formação musical, desde que se tenha claro de que ela não abrange tudo aquilo que se pode chamar de história da música.

Grande parte destes estudos não se propõe a ser "história da música", e alguns apresentam essa consideração explicitamente na introdução. Por exemplo, muitos dos trabalhos cuja periodização se situa no Estado Novo, buscam ampliar a compreensão desse momento político da história do Brasil através da música popular do período e suas inter-relações com a política e o poder do Estado, sem que o objetivo central fosse fazer história da música. Ainda que este não fosse o objetivo central, estes trabalhos resultaram em contribuições ou debates importantes para uma história da música popular. É o caso do trabalho pioneiro de Antônio Pedro, Samba da Legitimidade, estudo da ideologia do trabalhismo e das relações dos compositores e da canção popular com a ditadura de Getúlio Vargas. Em Sinal Fechado: a música popular brasileira sob censura (1937-1945 / 1969-1978), Alberto Moby se propõe a fazer uma análise comparada do papel da censura no Estado Novo e no regime militar, identificar a política destes regimes autoritários para a cultura em geral e quais eram os objetivos ao censurar ou não as canções, bem como verificar a posição dos compositores frente ao regime e à censura. Simone Luci Pereira afirma que sua "pesquisa se insere entre as preocupações de analisar não tanto a história da música, mas procurando-se refletir, 
analisar as relações entre história e música". ${ }^{430}$ Ramon Casa Vilarino, no prefácio à 5a edição de MPB em movimento: música, festivais e censura, publicação de sua dissertação homônima, afirma que seu objetivo foi empreender uma análise da ditadura militar implantada no Brasil em 1964 e a música foi o fio condutor da análise. Assim, para o autor, trata-se de um livro de história e não de um livro sobre música. ${ }^{431}$ Também Carlos Alberto Zeron em Fundamentos histórico-políticos da música nova e da música engajada no Brasil a partir de 1962 procura deixar claro que seu trabalho não tem o objetivo de ser história da música. Após afirmar, apoiado numa breve revisão da literatura então disponível, que muitos dos trabalhos que utilizam o discurso musical como objeto de estudo não têm caráter propriamente historiográfico, observa que "no nosso caso, igualmente, a escolha da música como fundamento da documentação abordada não implica numa proposta de se fazer história da música”. 432

De fato, estes trabalhos estudam relações entre música e política e entre música e experiências urbanas, no caso de Luci Pereira. 0 trabalho de Zeron é, entre estes, o mais difícil de não situar como história da música, uma vez que o autor discute a produção de autores influentes nos rumos da música erudita brasileira na segunda metade século XX e as concepções ideológicas que nortearam seu projeto estético. 0 fato destes autores ressaltarem que seus estudos não se propõem a ser história da música, talvez possa ser lido como uma manifestação de que não se trata de uma história da música no sentido convencional, a sucessão linear de estilos, autores e obras. Parece que esse sentido está também presente na expressão História e Música.

\subsection{A ANÁLISE DO DISCURSO DO TEXTO LITERÁRIO DAS CANÇÕES}

Grande parte dos trabalhos dentro de nosso recorte cronológico ainda estava muito dependente da metodologia da análise do discurso do texto literário das canções como fonte para reflexões histórico-sociológicas. Os trabalhos que em maior ou menor grau se utilizam desta metodologia são: Samba da Legitimidade; Capoeiras e malandros: pedaços de uma sonora tradição popular; O sertão no embalos da música rural, Sinal

\footnotetext{
430 PEREIRA, Simone Luci. Bossa Nova é sal, é sol, é sul. Dissertação de mestrado em História. PUC-SP, 1998, p. 16. 431 VILARINO, Ramon Casas. A MPB em movimento. 5a ed. São Paulo: Olho d'Água, 2006, p.6.

432 ZERON, Carlos Alberto de Moura Ribeiro. Fundamentos histórico-políticos da música nova e da música engajada no Brasil a partir de 1962. Tese de doutorado. São Paulo: FFLCH-USP, 1991, p. 14.
} 
fechado: a música popular brasileira sob censura, Dimensões da vida urbana sob o olhar de Chico Buarque; No ar: amores amáveis; A jovem guarda e os anos 60: uma festa de arromba; A MPB em movimento: músicas festivais e censura; Jovens tardes de guitarras, sonhos e emoções; O combate ao samba e o samba de combate; Bossa nova é sal, é sol, é sul; Banho de lua: o rock nacional de Celly Campello a Caetano Veloso.

No caso de Sinal Fechado, e também, de certa forma, de A MPB em movimento, isso pode encontrar uma justificativa no fato de que estes trabalhos abordam a questão da censura, que operava sobre o texto literário. Mas, mesmo neste caso, a questão sonora, a escuta, seria fundamental. Além do mais, um conjunto de canções pertencentes a outra vertente da música brasileira popular que não aquela da tradição da chamada música popular brasileira ou MPB, igualmente censuradas, ficaram de fora da análise destes trabalhos, algumas das quais, no plano do texto literário, com críticas mais contundentes ao regime militar do que muitas das canções da MPB censuradas, como demonstrou Paulo Cesar Araújo em Eu não sou cachorro, não. Ou seja, estas canções não foram excluídas pela sua letra, mas porque não fazem parte da vertente principal da canção brasileira, entre outros fatores, pelos seus aspectos sonoros, sua linguagem musical.

De uma maneira geral, a metodologia centrada na análise das letras das canções ainda estava presente nos trabalhos da área de História, mesmo que, neste caso, se utilizando do instrumental teórico próprio da área. Por exemplo, Maria Izilda Santos de Matos, professora da PUC-SP e orientadora de diversas pesquisas do campo $^{433}$, escreveu conjuntamente com Fernando Faria o livro Melodia e sintonia em Lupicínio Rodrigues: o feminino, o masculino e suas relações, no qual a análise está fortemente centrada nas letras das canções de Lupicínio.

Utilizar-se-á o termo canção em lugar de música "num sentido lato, isto é, abrangendo principalmente a letra, o universo que verbaliza cantando", como aponta José de Souza Martins em Música sertaneja: dissimulação na linguagem dos humilhados. 434

\footnotetext{
433 Apenas dentro do nosso corpo documental, podemos citar três trabalhos: FURTADO FILHO, João Ernani. $O$ combate ao samba e o samba de combate. Dissertação de mestrado em História. São Paulo: PUC/SP, 198; PEDERIVA, Ana Barbara Aparecida. Jovens tardes de guitarras sonhos e emoções. Dissertação de mestrado em História. São Paulo: PUC-SP, 1998; PEREIRA, Simone Luci. Bossa Nova é sal, é sol, é sul. Dissertação de mestrado em História. São Paulo: PUC-SP, 1998.

434 MATOS, Maria Izilda Santos de; FARIA, Fernando. Melodia e sintonia em Lupicínio Rodrigues: o feminino, o masculino e suas relações. Rio de Janeiro: Bertrand Brasil, 1996, p.20.
} 
Naturalmente, é legitimo utilizar essa ferramenta metodológica e, em alguns casos, ela é mesmo a melhor opção. Para a área de Letras, é evidente que o plano discursivo do texto literário das canções constitui um objeto de estudo interessante, e algumas canções oferecem um excelente material para esse tipo de análise. Também para certos objetos, como a questão da censura, ou mesmo a mencionada relação entre feminino e masculino, este pode ser um bom caminho. E, eventualmente, como instrumento complementar a outras análises, pode enriquecer um estudo. Nestes casos, não há por que não usá-la. 0 problema é esta metodologia como instrumental teórico privilegiado a priori para os estudos históricos da música popular urbana. Observe-se que nesta abordagem, de saída, já fica descartado como objeto de estudo tudo aquilo que não seja canção.

A utilização desta metodologia como ferramenta preferencial pode ser vista como um estágio, um momento formativo, uma vez que os autores demonstravam estar conscientes de que existiam limitações nessa metodologia. Assim como já ocorrera nos primeiros trabalhos das áreas de Letras e Comunicação, as pesquisas que adotam esta metodologia apresentam alguma explicação ou discussão sobre o fato do estudo estar fundamentalmente apoiado nas letras das canções. Por exemplo, Wolney Honório Filho, em $O$ Sertão nos embalos da música rural, após algumas considerações sobre a canção, afirma que

\begin{abstract}
No nosso caso, apesar de reconhecer a cumplicidade do som e da palavra na canção, esforçamo-nos frente à tentação de analisar seu som e concentramonos sobre suas palavras. Porém, esse recorte não elimina os problemas e os desafios. Falar do som, da nota emitida, do acorde presente, do tom que nos toca, não só ao ouvido como também a toda a sensibilidade, necessitaria de todo um arcabouço teórico musical um tanto quanto distante de minha experiência de vida.

[...] Para efeito de uma análise de história social a natureza sonora da música, no nosso caso, não será considerada. Porém, o problema permanece, podendo suscitar futuras pesquisas". 435
\end{abstract}

Também em Jovens tardes de guitarras, sonhos e emoções, de Ana Barbara Pederiva, encontramos esse posicionamento. A autora afirma que, "sem esquecer que a música comporta arranjo, acompanhamento instrumental, ritmo, entonação, modulação da voz e interpretação", seu trabalho não pretende o que ela chama de uma

435 HONÓRIO FILHO. Wolney. O sertão nos embalos da música rural 1929-1950. Dissertação de mestrado em História. PUC/SP, pp. 15-17. 
"leitura partitural” e, sim, "a análise das canções entendidas como poemas-canto, que abrangem a letra, isto é, o verbalizar cantando". ${ }^{436}$

Conforme indicado no Capítulo 2, a formulação de José de Souza Martins sobre o universo que verbaliza cantando foi um suporte importante nesta linha de pesquisa. Esta elaboração já se encontrava presente em Samba da Legitimidade.437 Também conforme discussão no Capítulo 2, nos anos 1970 e 1980, os estudos da música popular buscavam formulações para a abordagem das relações texto e melodia nas canções. Por volta de meados da década de 1990, os estudos de Luiz Tatit já haviam apresentado um marco teórico consistente para se pensar a questão da formação do sentido na canção. ${ }^{438}$ Assim, por volta do final da década de 1990, esta questão da relação entre texto literário e texto musical na canção popular já tinha um acúmulo de conhecimento desenvolvido em quase três décadas de pesquisas. Se muitos trabalhos ainda estavam presos à letra das canções, outros tantos já haviam enveredado por outros caminhos, apontando para uma superação desta opção metodológica como eixo central de pesquisa. Mas esta reflexão sobre esta metodologia baseada na análise do discurso do texto literário das canções não é importante apenas do ponto de vista da história da historiografia. Talvez em função da grande expansão do campo que ocorreu nos últimos anos, que combina o boom da pós-graduação no Brasil com a ampliação do interesse e do espaço para a discussão de temas relacionados à musica popular urbana, com a consequente entrada no campo de um grande contingente de novos pesquisadores, é possível que ela ainda encontre uma sobrevida. Esta metodologia está defasada em relação às linhas mais atualizadas de pesquisa; na verdade já estava superada por volta do final da década de 1990. Precisa ser definitivamente abandonada, ao menos como metodologia privilegiada para a pesquisa histórica da música popular.

\footnotetext{
436 PEDERIVA, Ana Barbara Aparecida. Jovens tardes de guitarras sonhos e emoções: fragmentos do movimento musical Jovem Guarda. Dissertação de mestrado em História. PUC/SP, p. 15.

437 TOTA, Antonio Pedro. Opus. cit., p.10.

438 A elaboração da contribuição metodológica de Tatit para os estudos da canção se deu entre a sua dissertação de mestrado (1982) e sua tese de livre docência (1994), quando seu sistema se encontrava num estágio superior de elaboração, com um formato praticamente acabado. Nestes textos, o autor não teve nenhuma preocupação de simplificar o discurso, são textos de elaboração teórica, de difícil leitura mesmo para iniciados em Semiótica e praticamente inacessíveis para leigos. Sua produção se popularizou no meio acadêmico com a publicação do livro $O$ Cancionista: composições de canções no Brasil (1995) no qual o autor apresenta suas teorias em texto voltado para um público mais amplo. Seus inscritos, desde então, tornaram-se referência importante para os estudos da canção popular brasileira. No entanto, suas elaborações teóricas não apresentam repercussão significativa na historiografia, ao menos até 1999, e enfrentam a resistência de alguns historiadores pela ênfase na análise sincrônica.
} 
De um modo geral, com algumas expressivas exceções, as primeiras pesquisas historiográficas sobre música popular não dispensavam maior atenção aos aspectos sonoros. Na verdade, já constituía uma grande novidade que um objeto anteriormente desconsiderado pela historiografia acadêmica fosse o tema de pesquisas de pósgraduação, artigos e ensaios de historiadores acadêmicos. Melhor dizendo, essa era, e em certo sentido ainda é, uma questão que transcende a música popular e a historiografia da música no Brasil, conforme José Geraldo Vinci de Moraes. 0 autor emprega a expressão "surdez dos historiadores", também utilizada por Myriam Chimènes, para apontar a ausência da música em geral no trabalho dos historiadores até por volta dos anos 1990.439 De fato, estes trabalhos estavam começando a superar um problema, a ausência da música na História, mas ainda persistia um resquício da "surdez dos historiadores" - expressão um tanto exagerada, provavelmente com objetivo polêmico - nestes pesquisadores pioneiros: os trabalhos, em geral, não tinham som. Muito raramente os aspectos sonoros da canções estavam contemplados na análise.

Temos que considerar aqui o ineditismo destas pesquisas. Possivelmente as características intrínsecas da música (imaterialidade, evanescência, atemporalidade, subjetividade, lógica abstrata de organização, intradutibilidade a narrativas textuais) estejam na raiz desta ausência da música na História, em processo de superação. Mas para estes primeiros historiadores de ofício que tomaram a música popular como objeto, não existiam metodologias disponíveis e trabalhos modelares nos quais se espelhar. Aliás, os trabalhos disponíveis, a historiografia não acadêmica da música popular, neste aspecto, indicavam mais o que não fazer; apontavam um caminho não para ser seguido, mas para ser submetido à análise crítica. Esta não abordagem do material sonoro pode ser entendida por esta inexistência de um instrumental, que iria sendo construído ao longo do tempo no curso das pesquisas do campo.

\footnotetext{
439 Sobre esta questão, ver: MORAES, José Geraldo Vinci de. Sons e música na oficina da História. In: REVISTA DE HISTÓRIA. São Paulo: Humanitas/FFLCH-USP, no 157, 2007, pp. 7-13.; CHIMÈNES, Myriam. Musicologia e História: fronteiras ou "terra de ninguém" entre duas disciplinas? In: REVISTA DE HISTÓRIA, no 157, 2007, pp. 15-29; MORAES, José Geraldo Vinci de; SALIBA, Elias Thomé. 0 historiador, o luthier e a música. In: MORAES; SALIBA (orgs.). História e Música no Brasil. São Paulo: Alameda, 2010.
} 


\subsection{ABORDAGENS HISTÓRICO-SOCIOLÓGICAS E ANÁLISE TÉCNICO-ESTÉTICAS: ALGUMAS REFLEXÕES}

Na Introdução de Capoeiras e malandros: pedaços de uma sonora tradição popular, Maria Ângela Salvadori, após considerações acerca das experiências urbanas das camadas sociais que estiveram na origem do samba carioca, afirma que, por um conjunto de razões, a música dos negros "não pode ser tomada como objeto histórico apenas em seu aspecto técnico. Deveria, ao contrário, ser considerada como um documento sonoro que constituiu elemento essencial do cotidiano dos negros pobres do Rio de Janeiro".440 Está certo que esta música não deve ser observada historicamente apenas em seu aspecto técnico, mas a questão tem uma amplitude maior. Nenhuma música deve ser tomada como objeto histórico apenas no seu aspecto técnico, na análise fria do texto musical, no sentido de que isso não alcança toda sua complexidade enquanto objeto de cultura. Ou seja, para se compreender a música como um fenômeno humano inserido num contexto social, ela terá que ser abordada sob diversos aspectos, inclusive o técnico. Isso não exclui, naturalmente, que uma abordagem histórica apenas do aspecto técnico também seja possível e válida. Teríamos então uma história da técnica, conforme discutido no item anterior, que é mais ou menos o que a musicologia tradicional entendia por história da música e o que, por vezes, ainda é ensinado nas disciplinas de História da Música Ocidental nos conservatórios e mesmo cursos superiores de música. ${ }^{441}$ Na mesma introdução, Salvadori afirma ainda que durante boa parte da pesquisa, estava utilizando apenas a letra das composições, "deixando de lado sua sonoridade". Apercebeu-se então, no curso do trabalho, que "um documento sonoro tornava-se silencioso sobre uma folha de papel" e que, desta forma, "empobrecia, ao mesmo tempo, o documento, a história

\footnotetext{
440 SALVADORI, Maria Ângela Borges. Capoeiras e malandros: pedaços de uma sonora tradição popular (1890-1950). Dissertação de mestrado em História. IFCH-UNICAMP, 1990, p.19.

441 Em agosto de 2010 foi realizado o 1o Simpósio Internacional para a Pedagogia da História da Música, promovido pelo então Departamento de Música da ECA-USP de Ribeirão Preto. 0 evento teve o objetivo de discutir perspectivas teóricas e metodológicas da disciplina e serviu como um termômetro para se avaliar o estado da arte e a temperatura do debate das distintas concepções de história da música entre professores e alunos presentes. A iniciativa demonstrou que existe uma preocupação quase generalizada em atualizar a disciplina e as concepções acerca das relações entre História e Música, assim como se evidenciaram as angústias e impasses advindos da demolição do paradigma tradicional sem que uma outra perspectiva tenha se consolidado como alternativa universalmente aceita de superação dos problemas propostos pela etnomusicologia, pela história renovada e pelos estudos culturais. Entretanto, é de se ressaltar o fato de que nenhum historiador de ofício tenha sido convidado entre os palestrantes e debatedores.
} 
que ele contava e o próprio trabalho". ${ }^{442}$ Empreendeu assim um esforço no sentido de incorporar elementos sonoros, como por exemplo, a percepção de que o repertório de canções com as quais trabalhava era composto majoritariamente por "sambas-debreque", nos quais a fala cotidiana se fazia presente, o que favorecia o discurso de seus personagens identificados com a malandragem. Observou também que, ao falar sobre o trabalho, os compositores optavam geralmente pelo ritmo de marcha em detrimento do samba-de-breque. Embora a dissertação tenha agregado aspectos sonoros a partir da percepção de que elementos importantes estavam se perdendo ao se trabalhar exclusivamente com as letras, isto ainda ocorreu de maneira bastante incipiente. $\mathrm{Ou}$ seja, podemos perceber nesta introdução de Capoeiras e malandros alguns dos impasses metodológicos que se colocavam para as pesquisas historiográficas que se colocavam na interseção entre história e música.

Podemos então observar, por um lado, as limitações de uma concepção de história da música centrada nos aspectos técnico-estruturais ou estéticos, uma visão histórica válida e importante, mas necessariamente parcial; por outro, a tendência da história escrita pelos historiadores de focar as relações entre música e história nas suas conexões com aspectos políticos, socioeconômicos e culturais, ou mesmo a utilização da música apenas como fonte documental privilegiada.

\begin{abstract}
Normalmente existem duas formas básicas de abordagem: uma que prioriza um olhar externo à obra e outra que procura suas articulações internas, estruturais. Os campos da história, da sociologia e da comunicação, tendem mais para o primeiro caso. Os campos da semiótica, da musicologia e das letras, tendem mais para a segunda abordagem. Mesmo assim, esta tensão é presente e assumida, mesmo nestes casos bem sucedidos. ${ }^{443}$
\end{abstract}

As reflexões acerca das relações entre texto e contexto, sincronia e diacronia, e articulação entre abordagens histórico-sociológicas e análise técnico-estética estão colocadas para o estudo e a história das diversas linguagens artísticas. Em Literatura e sociedade: estudos de teoria e história literária, de 1965, Antonio Candido apresentou proposições no plano da crítica literária, que, apesar das especificidades da linguagem

\footnotetext{
442 Ibidem, p. 20.

443 NAPOLITANO, Marcos: História e música popular: um mapa de leituras e questões. In: REVISTA DE HISTÓRIA. São Paulo: Humanitas/FFLCH-USP, no 157, 2007, p. 154.
} 
musical, podem oferecer elementos para se pensar estas questões. 0 autor afirma procurar focalizar "vários níveis da correlação entre literatura e sociedade", evitando o ponto de vista que considerava mais usual, o qual denomina de "paralelístico", que consiste "em mostrar, de um lado, os aspectos sociais, e, de outro, sua ocorrência nas obras, sem chegar ao conhecimento de uma efetiva interpenetração". ${ }^{444}$ Podemos observar este tratamento paralelístico em alguns dos trabalhos do nosso corpo documental que enveredaram pela análise estrutural, por exemplo em Tangos Brasileiros $^{445}$, tratamento este também muito frequente nas pesquisas da área de Música.

Segundo o autor, já estava estabelecido naquele momento para a crítica literária que só é possível entender a integridade da obra considerando "texto e contexto numa interpretação dialeticamente íntegra", em que tanto o ponto de vista que busca explicar a obra pelos fatores externos, quanto aquele norteado pela ideia da independência da estrutura "se combinam como momentos necessários do processo interpretativo". 0 externos à obra importaria, "não como causa, nem como significado, mas como elemento que desempenha um certo papel na constituição da estrutura da obra, tornando-se, portanto, interno". Quando no estudo crítico da obra os elementos externos se tornam internos, a crítica deixaria de ser sociológica para ser apenas crítica e o elemento social seria apenas um dos muitos a interferir na "economia interna da obra". 446

Neste ponto, o autor faz uma distinção entre disciplinas. Note-se que nesta elaboração está tratando do papel da sociologia na crítica literária. 0 "tratamento externo de fatores externos" (ou seja, sem análise da estrutura) seria legítimo quando se trate de sociologia da literatura, pois não sendo o objeto a questão do valor da obra, pode o estudo interessar-se por outros condicionamentos sem a orientação estética assumida pela crítica. ${ }^{447}$ Em Formação da Literatura Brasileira, obra de referência para a história literária, Antonio Candido afirma ter procurado "apreender o fenômeno

\footnotetext{
444 CANDIDO, Antonio. Literatura e sociedade: estudos de teoria e história literária. São Paulo: Companhia Editora Nacional, 1965., p. 1.

445 AUGUSTO, Paulo Roberto Peloso. Tangos brasileiros, Rio de Janeiro: 1870/1920. Tese de doutorado em História. São Paulo: FFLCH-USP, 1996. Creio que mesmo na tese de Arnaldo Contier Brasil Novo: música, nação e modernidade, trabalho que apontou um caminho metodológico para a abordagem da música na história, esta questão não estava resolvida.

446 CANDIDO, Antonio. Op. cit., p. 4-12.

447 Ibidem, p.4.
} 
literário da maneira mais significativa e completa possível, não só averiguando o sentido de um contexto cultural, mas procurando estudar cada autor na sua integridade estética".

\begin{abstract}
A tentativa de focalizar simultaneamente a obra como realidade própria e o contexto como sistema de obras parecerá ambiciosa a alguns, dada a força com que se arraigou o preconceito do divórcio entre história e estética, forma e conteúdo, erudição e gosto, objetividade e apreciação. Uma crítica equilibrada não pode, todavia, aceitar estas falsas incompatibilidades, procurando, ao contrário, mostrar que são partes de uma explicação tanto quanto possível total, que é o ideal do crítico, embora nunca atingido em virtude das limitações individuais e metodológicas. ${ }^{448}$
\end{abstract}

Ao propor seu método ao mesmo tempo histórico e estético para o estudo da formação da literatura brasileira, Antonio Candido afirma a impossibilidade de uma crítica centrada nos aspectos estruturais da obra ou nos aspectos externos, quando se erigem em método exclusivo ou predominante. Mas considera lícito estudar apenas as questões sociais em torno a um determinado conjunto de obras, as biografias dos autores, ou a estrutura interna de uma obra, desde que se tenha claro o âmbito das disciplinas. "As orientações formalistas, não passam, todavia, do ponto de vista de uma crítica compreensiva, de técnicas parciais de investigação; constituí-las em método explicativo é perigoso e desvirtuaria os serviços que poderiam prestar, quando limitadas ao seu âmbito. ${ }^{449}$

Estas elaborações de Antonio Candido, aqui apenas esboçadas, ainda que formuladas para a crítica literária, ou seja, a análise das obras, oferecem elementos iniciais para se pensar as relações entre texto e contexto, análise sócio-histórica e técnico-estética no objeto artístico no contexto acadêmico brasileiro. Entretanto, no nosso caso, é preciso considerar as especificidades da linguagem musical e sua irredutibilidade a um discurso verbal. A música possui princípios de estruturação da linguagem que obedecem a lógicas específicas de diversos sistemas de organização do material musical constituídos na cultura. No caso da tradição ocidental, o discurso musical atingiu um grau muito elevado de racionalização, no amplo arco que vai do modalismo do cantochão, passando pela tonalidade, até as variadas técnicas

\footnotetext{
448 CANDIDO, Antonio. Formação da literatura brasileira: momentos decisivos 1750-1880. 12a ed. São Paulo/Rio de Janeiro: FAPESP/Ouro sobre azul, 2009, p. 31. Primeira publicação em 1957.

${ }^{449}$ Ibidem, p.34-35.
} 
composicionais desenvolvidas no século XX. Surgida inicialmente apoiada no texto literário, a música ocidental foi, ao longo do tempo, ganhando independência das formas vocais. 0 surgimento das formas musicais puramente instrumentais implicou a construção de um discurso musical que fizesse sentido em si mesmo. Estas formas instrumentais adquirem então uma certa narratividade e o sistema tonal e as formas musicais, especialmente a forma sonata, foram os veículos através dos quais esta narratividade se expressou. Mas obviamente não é possível através do discurso musical a apresentação de idéias estruturadas que não digam respeito à música em si mesma, ainda que seja possível a expressão de sentimentos genéricos associados culturalmente a certas formas de organização do material musical. ${ }^{450}$ Claro que, em se tratando de música vocal, existe o componente verbal na formação do sentido, o que coloca a análise em outro plano.

Isto posto, se apresenta a questão de como localizar na estrutura interna da obra, ou seja, no texto musical propriamente dito, especialmente no caso da música puramente instrumental, a presença ou a influência dos elementos e fatores externos; como articular na análise os elementos internos e externos, sincronia e diacronia. Embora esta não seja uma barreira necessariamente intransponível, é um elemento complicador bastante considerável para este tipo de abordagem, pois implica a capacidade de análise estrutural da obra por parte do historiador da música e na tradução para a linguagem verbal de elementos não verbais; ou, no domínio por parte do músico historiador, do instrumental teórico da História e das Ciências Sociais.

Observe-se que sistemas mais complexos e estruturados oferecem mais elementos para se notar perturbações, variações e transformações em sua lógica interna. Em Mozart: sociologia de um gênio, ${ }^{451}$ sem precisar recorrer a especificidades do texto musical, Norbert Elias aponta como as transformações socioeconômicas em curso, a ruptura de Mozart com a corte de Salzburgo, sua ida para Viena para se tornar artista autônomo e as consequências dessa aventura iriam influir decisivamente na sua produção musical. Charles Rosen indica como o surgimento da forma sonata, momento importante e decisivo na história da música ocidental, está relacionado com o

\footnotetext{
450 Sobre as relações entre melodia e prosódia ver: CARMO Jr., José Roberto do. Melodia \& prosódia: Um modelo para a interface música-fala com base no estudo comparado do aparelho fonador e dos instrumentos musicais reais e virtuais. Tese de doutorado em Linguística. São Paulo: FFLCH-USP, 2007.

${ }^{451}$ ELIAS, Norbert. Mozart, sociologia de um gênio. Rio de Janeiro: Zahar, 1995.
} 
surgimento de novas camadas sociais que, detentoras do poder econômico, queriam ter acesso à cultura até então desfrutada apenas por aqueles que compartilhavam da vida na corte. Impunha-se assim, a formatação de uma linguagem musical mais inteligível para este novo público que surgia do que as complexas texturas musicais do barroco tardio. ${ }^{452}$ Um outro exemplo é a análise que Thales Messias fez da ópera Wozzeck, de Alban Berg, tendo como referência o estudo de Carl Schorske acerca das relações entre política e cultura na sociedade vienense do final do século XIX.453 Para Messias, "por trás da magistral concepção e estruturação musical de Wozzeck, subjazem influências que vão muito além das orientações puramente técnicas: há também ali a manifestação de toda uma época, que é inconscientemente revelada pelo artista através da sua obra". 454

É necessário acrescentar que, no caso da música artística europeia, além de tratar-se de um sistema complexo e estruturado do ponto de vista da organização do material sonoro, o que facilita a percepção de perturbações, variações e transformações em sua lógica interna, a música erudita foi institucionalizada enquanto sistema sociocultural fechado: compõe-se de uma linguagem básica, de formas aceitas, repertório, teorias e técnicas de composição e análise, sistema de ensino, panteão de gênios, formas de sociabilidade, critérios de avaliação crítica e juízos de valor bem definidos. Embora parte das vanguardas do século XX tenham tentado implodir este sistema, ele permanece, e a produção das vanguardas foi, ainda que com tensões, incorporada a esse sistema. No caso da música popular, surgida em estreita relação com o mercado de bens culturais, este processo de institucionalização foi mais irregular e descontínuo, embora também tenha acontecido, de maneira desigual e particularmente com gêneros como o jazz, o samba, o tango e a rumba,

452 ROSEN, Charles. Formas de sonata. Cooper city: Span press, 1999. Ver também do mesmo autor: The classical style: Haydn, Mozart e Beethoven. Nova York: W.W. Norton, 1997; A geração româtica. São Paulo: EDUSP, 2000.

453 SCHORSKE, Carl E. Fin-de-siècle Vienna: politics and culture. Crawfordsville, Indiana, USA: R.R. Donnelley \& Sons Company, 1981. Neste texto encontra-se a definição de Schorske que Chartier afirmou parecer ser a única atualmente válida para a história cultural, na medida em que indica apenas a dupla dimensão de um trabalho, sem lhe atribuir nem metodologia nem conceitos determinados: "O historiador procura localizar e interpretar temporalmente o artefato num campo em que se intersectam duas linhas. Uma linha é vertical, ou diacrônica, pela qual ele estabelece a relação de um texto ou de um sistema de pensamento com as manifestações anteriores no mesmo ramo de atividade cultural, (pintura, política, etc.). A outra é horizontal, ou sincrônica; através dela, determina a relação do conteúdo do objeto intelectual com o que vai surgindo ao mesmo tempo noutros ramos ou aspectos de uma cultura." Entretanto, Chartier afirma que, por detrás da força da evidencia desta proposição, ela encerra ainda algumas armadilhas, como os conceitos de objeto intelectual e cultura. CHARTIER, Roger. A História Cultural: entre práticas e representações. Algés, Portugal: Diefel Editorial, 1990, p. 63-64.

454 MESSIAS, Thales de Oliveira. O expressionismo musical: uma análise estética. Monografia de TCC. Uberlândia: UFU, 2010, p. 74. 
que se confundiram com a afirmação de identidades nacionais dos seus respectivos países. ${ }^{455}$ Especialmente no caso do jazz, esta institucionalização chegou mais próxima da constituição de um sistema sociocultural fechado (linguagem básica, formas, repertório, teorias, técnicas, sistema de ensino, panteão de gênios, formas de sociabilidade, critérios de avaliação crítica e juízos de valor), tendo sido construída toda uma bem estruturada elaboração teórica e um sistema de ensino que informou os estudos técnicos da música popular no plano internacional, incluindo, é claro, o nosso país. ${ }^{456}$ Mas, para a música brasileira popular tomada de conjunto, inexistia algo semelhante, que oferecesse referências para a abordagem dos fatores internos das obras em relação aos seus aspectos externos.

Desta forma, é possível compreender que a análise do discurso do texto literário das canções tenha sido uma primeira abordagem, tanto mais que a área de Música demorou para incorporar o objeto. Como observado no item 6.3, um conjunto de trabalhos ainda estava preso à análise do texto literário. Mas, uma vez superada esta opção metodológica, colocava-se o problema de como abordar as questões textuais, formais, internas ao material musical em questão. E aí podemos localizar duas tendências: uma historiografia que não se desenvolveu afastada dos aspectos da linguagem artística propriamente dita e uma vertente que procurou incorporar, em distintas aproximações, estes aspectos.

\subsection{AS RELAÇÕES (E TENSÕES) ENTRE A PRODUÇÃO HISTORIOGRÁFICA, OS ESTUDOS SOBRE A MÚSICA POPULAR E AS MUSICOLOGIAS.}

0 problema metodológico da articulação numa análise integrada do texto musical com os fatores sócio-histórico-culturais ainda é uma questão em aberto, ou que ao menos não estava resolvida dentro do recorte cronológico desta pesquisa, ainda que se possa especular que se tenha avançado muito nos últimos dez anos. Esta é a

\footnotetext{
455 Devo estas considerações acerca do processo de institucionalização da música artística europeia e da música popular urbana, assim como outras elaborações presentes neste trabalho, a sugestões de Marcos Napolitano. No entanto, a aceitação e desenvolvimento de suas indicações, assim como quaisquer eventuais distorções e mal entendimento de suas observações, são de minha inteira responsabilidade.

456 Para este processo de institucionalização do jazz, ver: SNYDER, Randy L. College jazz education during the 1960: its development and acceptance. PhD Thesis. University of Houston, USA, 1999; COLLIER, James Lincoln. Jazz: a autêntica música americana. Rio de Janeiro: Zahar, 1995. Como exemplos de tratado de teoria musical e de arranjo, respectivamente, no campo jazzístico: RUSSELL, George. The lydian chromatic concept of tonal organization. Nova York, Concept Publishing Co.; NESTICO, Sammy. The complete arranger. Fenwood Music Co., 1993. Em relação ao método de ensino, a série de play-along desenvolvida por Jamey Aebersold constituiu-se em best-sellers internacionais e contribuiu, juntamente com os clássicos real-books, para a fixação do repertório e prática da linguagem.
} 
principal resistência dos músicos às pesquisas realizadas na área de História, ainda que a Musicologia tampouco tenha chegado a uma solução plenamente satisfatória para a questão. Aliás, esta é uma preocupação recente na disciplina, cuja atualização metodológica dá-se a partir dos anos 1980.

A História da Música é uma disciplina que pressupõe o encontro da História com as musicologias. A quem compete escrever a história da música, aos músicos ou aos historiadores? A ambos, acredito, uma vez que se tenha rompido com a perspectiva de uma história totalizante, capaz de contemplar todas as músicas, de todas as épocas, de todas as culturas, em toda a sua complexidade nas relações entre os elementos externos e internos. É preciso assumir que essa será sempre uma história parcial, que vai olhar para um certo conjunto de obras e historicizá-las sob certos aspectos. Os músicos, ao fazerem história da música, tendem a privilegiar os aspetos da estruturação formal das obras e também, acrescente-se, um repertório que favoreça essa abordagem, seja a música artística europeia ou, no caso da música popular, o jazz, o choro, a bossa nova ou a música instrumental. A história escrita por historiadores de ofício, como se pode observar nos trabalhos analisados nesta tese, privilegia a abordagem de uma história social da música que enfoque as relações entre música e política, sociedade e cultura. Por outro lado, o repertório abordado é mais amplo, ainda que existam restrições anteriormente apontadas. Ou seja, aqui ocorre o mesmo balanço entre competências que Merriam observou, para o campo da Etnomusicologia, entre pesquisadores com formação em Antropologia e aqueles com formação em Música.

É possível pensar em uma gradação nas abordagens da história da música entre leituras mais voltadas para aspectos de estruturação musical, seja apoiado na musicologia ou mesmo na linguística para o caso da canção, de um lado, e abordagens sócio-político-culturais, de outro, todas elas válidas e muitas vezes, complementares, uma vez que muitos são os ângulos sob os quais se pode pensar uma história da música. No limite, as disciplinas de Teoria Musical, Harmonia, Análise e Literatura Musical (repertório) existentes nos cursos de música com estes ou outros nomes, e até mesmo os estudos de performance, quando pensados historicamente, contribuem para uma história da técnica musical. Num outro pólo, teríamos uma história social da música que enfatize os aspectos do contexto histórico-social. Especialmente no caso da música 
popular, também se pode fazer uma distinção entre uma historiografia que toma a música (ou a canção) como objeto principal da pesquisa histórica, que se proponha a observar a história da música propriamente dita, por um lado, e aquela que utiliza a música como fonte documental privilegiada para estudos de outros objetos e compreensão de outros fenômenos, por outro. Neste caso, aspectos estruturais são ainda de menor importância, praticamente irrelevantes. Certamente todas estas abordagens têm a contribuir para a compreensão da música enquanto fenômeno de humanidade.

Existe, porém, uma certa resistência dos músicos à historiografia da música realizada por historiadores de ofício, especialmente àquela que se atém à música popular, que por um conjunto de fatores tem sido pensada com maior contextualização histórico-sociológica. Esta resistência é geralmente localizada no fato de que a maioria dos trabalhos realizados na área de História não se debruçam sobre os aspectos internos do texto musical. Por outro lado, resistências existem de ambas as partes. Perguntado sobre os trabalhos acadêmicos dos músicos, Arnaldo Contier respondeu que os músicos fazem "uma história muito tradicional, a pior possível", do tipo " $a$ história do violão", em trabalhos geralmente superdescritivos e mal redigidos, ainda que ele identifique a existência também de coisas boas nessa produção. ${ }^{457}$

Além dos problemas das teorias e métodos, é preciso considerar as questões de poder e prestígio, as hierarquias de legitimidades, que fazem parte da natureza das instituições em geral, e do campo científico em particular. Segundo Pierre Bourdieu, o campo científico, constituído como um "sistema de relações objetivas entre posições adquiridas em lutas anteriores", é o espaço de uma "luta concorrencial" por uma "espécie particular de capital social". O que estaria em jogo, nestas lutas, seria o monopólio da competência ou autoridade científica entendida como conjunção de capacidade técnica e poder social, ou seja, enquanto capacidade de falar e agir legitimamente, “de maneira autorizada e com autoridade”. Nesta concepção, fica descartada uma possível dissociação entre o que seria a autoridade enquanto posição na hierarquia de legitimações científicas e o que seria pura capacidade técnica, na medida em que fazer esta dissociação seria "cair na armadilha constitutiva de todo o

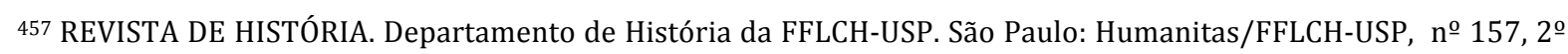
semestre de 2007, p.191. 
tipo de competência, razão social que se legitima apresentando-se como razão puramente técnica". 458 Desta forma, não existiria uma atividade científica "desinteressada", e aquilo que se chama de "interesse" por uma atividade científica teria sempre uma dupla face, ocorrendo o mesmo com as estratégias que visam assegurar a satisfação desse interesse. Bourdieu faz um paralelo entre a oposição encontrada nos debates da história da arte em relação às análises internas e externas da obra e à questão proposta para uma ciência da ciência entre epistemologia e condições sociais do surgimento das teorias científicas:

\begin{abstract}
Uma autêntica ciência da ciência só pode constituir-se com a condição de recusar radicalmente a oposição abstrata (que se encontra também na história da arte, por exemplo) entre uma análise imanente ou interna, que caberia mais propriamente à epistemologia e que restituiria a lógica segundo a qual a ciência engendra seus próprios problemas e, uma análise externa, que relacionaria esses problemas às condições sociais de seu aparecimento. É o campo científico, enquanto lugar de luta política pela dominação científica, que designa a cada pesquisador, em função da posição que ele ocupa, seus problemas, indissociavelmente políticos e científicos, e seus métodos, estratégias científicas que, pelo fato de se definirem expressa ou objetivamente pela referência ao sistema de posições políticas e científicas constitutivas do campo científico, são ao mesmo tempo estratégias políticas. ${ }^{459}$
\end{abstract}

Nesta luta pela acumulação do capital científico, entendido como autoridade ou competência dentro da concepção aqui exposta, os produtores tendem a "ter como clientes seus próprios concorrentes". Quanto maior a autonomia do campo, tanto mais acentuada será esta relação. Ou seja, "num campo científico fortemente autônomo, um produtor particular só pode esperar o reconhecimento do valor de seus produtos" dos outros pesquisadores que, sendo ao mesmo tempo público e concorrência, "são os menos inclinados a reconhecê-lo sem discussão ou exame". Nos diversos ramos do conhecimento, especialmente naqueles mais fortemente autônomos, somente os pesquisadores engajados no mesmo jogo (a luta concorrencial pela acumulação do capital científico) detêm os meios e também a legitimidade acadêmica "de se apropriar simbolicamente da obra e avaliar seus méritos". Nesta luta que cada produtor precisa enfrentar para afirmar o valor da sua produção e sua própria legitimidade dentro do

458 BOURDIEU, Pierre. O campo científico. In: ORTIZ, Renato (org.). Pierre Bourdieu. Coleção Grandes Cientistas Sociais. São Paulo: Ática, 1983, p.122-127.

459 Ibidem, p. 126. 
campo, conforme Bourdieu, é parte do jogo "o poder de impor uma definição de ciência" (no nosso caso, da disciplina História da Música), enquanto delimitação de problemas, teorias e metodologias, "que esteja mais de acordo com seus interesses e habilidades específicas". A definição mais apropriada tenderá a ser sempre aquela que assegure a um pesquisador determinado a melhor posição na hierarquia acadêmica, valorizando sempre as qualificações cientificas de que ele é detentor. Existiria, assim, uma hierarquia social das disciplinas que orienta as "escolhas" e "vocações" e, no interior de cada uma delas, "uma hierarquia social dos objetos e dos métodos de tratamento". 460

Uma vez que aceitemos esta sociologia da ciência, fica evidentemente ingênua uma discussão metodológica para a construção da história da música apoiada exclusivamente numa epistemologia pura, desvinculada das questões de poder e das lutas internas no campo científico visando posicionamentos na hierarquia de legitimidades. Ou seja, as restrições dos músicos a uma história social da música que não privilegie os aspectos estruturais do material musical, por um lado, e dos historiadores a uma história da música que se constitua fundamentalmente apoiada em aspectos técnico-estéticos desvinculados do contexto em que se constituíram (ou mesmo que não esteja em dia com os debates teórico-metodológicos propostos pelas novas correntes da disciplina), por outro, tem que ser pensadas também enquanto parte da luta concorrencial pelo monopólio da autoridade científica. Isto não invalida que existam de fato diferenças de concepção e que as reflexões acerca das distintas posições sejam fundamentais para se avançar o conhecimento; apenas aponta que há mais coisa em jogo e que estas polêmicas têm que ser observadas à luz da dinâmica que caracteriza os embates no campo acadêmico.

Posto que parece existir um certo consenso em torno da impossibilidade de uma história da música universal e totalizante, é inevitável a conclusão de que todas histórias da música serão necessariamente parciais em termos de objetos, enfoques e métodos. E todas estas histórias parciais, como suas distintas abordagens, sejam elas realizadas por historiadores, músicos ou pesquisadores advindos de outros campos, podem contribuir para aumentar nosso conhecimento e compressão da história da 
música. A historiografia da música popular realizada na área de História não esgota todas as possibilidades do conhecimento histórico acerca desta música, mas não resta dúvida que vem contribuindo decisivamente para seu conhecimento, e ser desconsiderada pela eventual ausência de análise estrutural é uma estreiteza de visão que só pode ser compreendida à luz da luta pela hegemonia na disciplina. 


\section{CONSIDERAÇÕES FINAIS}

Ao longo deste trabalho, procurei analisar a produção historiográfica sobre música popular realizada nos programas de pós-graduação na área de História desde os primeiros trabalhos até 1999, final do século XX, momento em que o objeto já estava consolidado no campo acadêmico, ainda que buscando um melhor posicionamento na hierarquia de legitimidades. 0 projeto da pesquisa previa identificar e analisar os conteúdos, abordagens, conceitos, fontes e metodologias nas dissertações e teses em foco, localizar as tendências de pesquisa e sua dinâmica ao longo do tempo. 0 objetivo do trabalho foi apresentar um mapa analítico do processo formativo do campo historiográfico em torno da música popular no Brasil, bem como efetuar uma análise crítica deste processo. Neste sentido, este trabalho pretendeu construir uma reflexão teórico-metodológica numa perspectiva histórica e crítica, revisando a história da constituição e afirmação de um campo de estudos dentro das Ciências Humanas e, particularmente, da História.

Os intelectuais do nacionalismo musical, obcecados pelo projeto de criação de uma música artística nacional que se alimentaria de elementos musicais populares ainda não deturpados pela urbanização e pelo mercado, e a musicologia dominada por esta corrente estética, se desinteressaram pela música popular urbana. Mas, como o fenômeno cultural representado pela formação da música popular no Rio de Janeiro era pujante e nas primeiras décadas do século XX vai se entrelaçar com a política e os discursos vinculados à construção da identidade nacional, é natural que se articulasse um pensamento em torno desta música. Surge assim uma corrente de jornalistas, memorialistas, músicos, radialistas e aficionados, pessoas em maior ou menor grau ligadas ao campo de produção, que vão se constituir nos primeiros historiadores da música popular no Brasil, articulando um discurso que, apesar de nuanças interpretativas, tem em comum a exaltação do samba carioca elevado à categoria de música brasileira. Articulou-se em torno do samba um sistema de compositores, canções, intérpretes, público, crítica e relações como o mercado cultural em processo de estruturação. Serão gerados, nesse circuito, os discursos em defesa da "autenticidade" e da "tradição" da música brasileira, refratário à modernidade e às 
influências estrangeiras. Esta tendência teve diversos desdobramentos e até hoje reverbera no campo de produção, num pensamento de senso comum e encontra ainda alguns arautos entre escritores e jornalistas.

Os anos 1960 significaram para a música no Brasil a ruptura da hegemonia do nacionalismo musical no plano da música erudita com a atuação das vanguardas, a atualização estética da música popular no fluxo criativo que vai do surgimento da bossa nova, no final da década anterior, até a tropicália, e um incremento na diluição das já não muito rígidas fronteiras entre estes campos. Neste momento, mais uma vez a música popular no Brasil se cruzaria com questões político-ideológicas e com outras séries socioculturais, e sairia do intenso debate estético-político da década num patamar superior enquanto produto artístico. A partir de então, uma faixa da música popular, a bossa nova e setores identificados com a sigla MPB, realizaria, ironicamente e por vias tortas, o projeto do nacionalismo musical de construção de uma música artística verdadeiramente nacional. No contexto das lutas políticas e das transformações socioculturais dos anos 1960, a música popular se tornaria no Brasil objeto de um intenso debate intelectual, no qual se articularam distintos projetos estéticos, atuação política e visões das relações com o mercado cultural em processo de reorganização.

Após a radicalização da ditadura militar a partir da edição do AI-5, que mudou a agenda política da esquerda, este debate tendeu a se esvaziar. Os ensaios das décadas de 1970 e 1980 tiveram um caráter mais analítico, de formatação de um objeto e elaboração de teorias e métodos para o seu estudo. De certa forma, estes ensaios se inseriam numa conjuntura na qual, num primeiro momento, a esquerda e os setores democráticos da sociedade tentaram entender o que tinha acontecido e, num momento posterior, passaram para a resistência e o questionamento possível ao regime militar. A música popular vai ter para parte deste ensaísmo o aspecto de resistência à dominação: o samba como tática de resistência cultural negra e a MPB como resistência ao regime militar. Nestes estudos pioneiros, desenvolveu-se a metodologia da análise do discurso do texto literário das canções, que marcou fortemente o campo. Por outro lado, pode-se localizar a formação de um instrumental conceitual para o estudo da canção brasileira em suas especificidades estéticas e sócio-históricas, que se materializou em conceitos 
como poesia cantada, linha evolutiva, linguagem da fresta, rede de recados, biombos culturais e resistência cultural. Este conceitos, que procurei historicizar e analisar dentro de uma perspectiva crítica, demonstram, entretanto, originalidade na formação do campo no Brasil na busca de um caminho próprio para o estudo de um fenômeno cultural específico.

$\mathrm{Na}$ historiografia realizada nos programas da área de História, desde o primeiro trabalho, em 1980, até o final da década de 1990, existe uma diversidade de objetos e abordagens que incluem pesquisas sobre o surgimento de uma música urbana popular no Rio de Janeiro e em São Paulo, sobre a malandragem, estudos envolvendo música e política, pesquisas em torno de gêneros de música popular. Existem também trabalhos de corte biográfico e pesquisas sobre o rádio. Esta produção pode, de conjunto, ser englobada como história social da música, entendida num sentido amplo, como parte de uma postura historiográfica que se constituiu em contraposição à antiga historiografia política, e na qual a interdisciplinaridade tem papel destacado. Não apresenta um caráter harmônico e homogêneo do ponto de vista teórico-metodológico, uma vez que, em geral, são articuladas diversas tendências e referências, incluindo instrumentais teóricos de outras áreas, como a Sociologia, a Antropologia, a Linguística, a Semiótica e, mais raramente, a Musicologia. Em alguns trabalhos encontra-se um certo ecletismo teórico, do ponto de vista da filiação à correntes historiográficas mais delineadas.

Do ponto de vista dos temas das pesquisas, tiveram especial destaque os estudos envolvendo as relações entre música e política, que pode ser considerada a principal linha no período. Estes estudos de história política estão fundamentalmente centrados em dois momentos: a Era Vargas e os anos 1960. 0 tema das "origens" propriamente dito, muito presente na historiografia não acadêmica e em trabalhos de outras áreas, não tem presença marcante nos trabalhos da área de História. Mas diversas pesquisas abordam a constituição de gêneros de música popular, como a tropicália, a jovem guarda e o rock no Brasil. A elevação do status social da canção e de seus agentes é estudada em dois momentos nos quais é identificado um reposicionamento na hierarquia de valores culturais: os anos 1930, com a ascensão do samba à condição de um dos símbolos nacionais e a década de 1960, ao final da qual 
um setor da canção popular atinge o status de produto artístico. A malandragem é o tema central de alguns estudos, encontrando-se também como tema secundário em diversos trabalhos que discutem a caracterização e o posicionamento do personagem malandro na cultura e na sociedade brasileira. E outra linha temática seriam as questões comportamentais, de juventude, da vida urbana, do cotidiano, de imagens e representações de posições sociais.

Entre as questões mais frequentemente colocadas tem destaque a problemática do nacional e do popular na cultura brasileira. Essa temática encontra-se nas pesquisas acerca da malandragem carioca, nas discussões sobre a afirmação do samba como música nacional e um dos símbolos da brasilidade e nos estudos em torno da MPB, que, por volta de meados da década de 1990, passou a ser mais claramente percebida enquanto uma instituição sociocultural com afinidade com uma certa cultura política e um determinado lugar social. Também a expressão música popular brasileira, já utilizada antes da afirmação de seu acrônimo, tinha, e tem ainda hoje, um sentido agregado que se relaciona a um certo repertório, ainda que mais amplo que a posterior sigla MPB. Em ambos os termos, ecoam as concepções sobre o nacional-popular, tão fortes no Brasil até os anos 1970, bem como uma visão em torno de uma determinada linhagem da música popular. Por volta do final da década de 1990, inicia-se uma revisão da historiografia da música popular, a partir da percepção de que uma parcela expressiva da produção musical do país, consumida por amplas camadas da população, estava sendo esquecida pela historiografia. 0 questionamento da tendência a privilegiar e valorizar o repertório e agentes identificados com a linhagem da tradição samba-bossa-MPB indicou a premência de um olhar mais amplo para a música popular e a incorporação de outras sonoridades urbanas, seja na condição de documento histórico ou como objeto de estudo em si mesmo.

No que diz respeito aos conceitos e teorias que norteiam as análises, refletemse nesta historiografia as tendências pertencentes aos dois paradigmas dominantes na disciplina histórica: o marxismo, em suas distintas vertentes; e a Nova História e os historiadores e cientistas sociais que pensaram a história da cultura e influenciaram ou dialogaram com suas posições. Nos trabalhos pioneiros, são frequentes conceitos oriundos de leituras mais ortodoxas do marxismo, mas sua incidência tendeu a 
decrescer ao longo do tempo, prevalecendo, no campo marxista, visões renovadas como na linha representada pela historiografia inglesa. Alguns pensadores brasileiros encontram-se entre as referências importantes e, por volta do final do período, repercutem os trabalhos de estudiosos da cultura latino-americana. A pesquisa sobre música popular produzida no mundo anglo-saxão a partir dos anos 1980 demorou para incidir nas pesquisas brasileiras e sua influência se situa praticamente fora da periodização deste trabalho.

Foi também objeto de análise a utilização da música como fonte nesta historiografia, a partir de uma reflexão sobre os suportes para a composição e o registro musical. Constatou-se que todo o material musical submetido à análise estrutural nestas pesquisas está composto por obras que, de um modo geral e em diferentes graus, melhor se prestam para análises dentro dos parâmetros mais convencionais da musicologia. No caso da partitura, sua análise e utilização como fonte de pesquisa histórica dispunha das referências nas elaborações desenvolvidas nas disciplinas musicológicas. Quanto ao fonograma, entendido na forma de gravação comercial, suporte fundamental para a música popular urbana, sua utilização como fonte de pesquisa histórica é algo recente, e as pesquisas analisadas neste trabalho são as pioneiras, o que explica uma certa hesitação em sua utilização, uma vez que inexistiam modelos anteriores em que se basear.

Para os trabalhos com a periodização na primeira metade do século $\mathrm{XX}, \mathrm{o}$ acesso às fontes constituiu uma dificuldade considerável, dependendo em grande parte do trabalho diletante e da generosidade de colecionadores; hoje o acesso a este material já se encontra mais democratizado, por iniciativa mesmo destes pesquisadores, cujos acervos em parte encontram-se disponíveis para consulta pública. Observe-se, entretanto, que estas coleções obedeceram naturalmente, como todas as coleções, os critérios de seleção de seus organizadores, que expressavam seus interesses estéticos, visões dos processos em curso e escolhas em relação ao que merecia ser preservado. Para pesquisas com o foco em eventos mais recentes, a partir do momento em que se dá a consolidação do LP em vinil na década de 1960, o acesso às fontes é mais fácil. Porém, da mesma forma, inexistem acervos completos ou um levantamento exaustivo da discografia, o que pode acentuar certos silêncios e 
esquecimentos, bem como direcionar os pesquisadores àquilo que o mercado preservou, que as coleções reiteraram, ou ganhou destaque em narrativas anteriores. Outra parte importante do acervo documental é composta por escritos de memorialistas e jornalistas, contemporâneos aos acontecimentos, não apenas sobre a música de sua época, mas também sobre a vida urbana, as questões culturais em pauta e as transformações sociais em curso. Muitos trabalhos recorreram a fontes orais e de memória, seja através de depoimentos disponíveis ou de entrevistas originais.

Em relação às abordagens metodológicas, é preciso inicialmente destacar a repercussão nos primeiros trabalhos historiográficos da metodologia desenvolvida na área de Letras para a abordagem da canção, baseada no plano discursivo do texto literário como fonte para reflexões histórico-sociológicas. A utilização desta metodologia como ferramenta preferencial pode ser vista como um estágio, parte de um momento formativo. Mas esta abordagem já estava defasada em relação às linhas mais atualizadas de pesquisa e pode ser considerada superada, enquanto metodologia privilegiada para a análise da canção, por volta do final da década de 1990. Entretanto, marcou tão fortemente o campo dos estudos da música popular, de um modo geral, que parte da resistência de setores da musicologia em relação aos estudos de outras áreas ainda se baseia na percepção defasada de que a análise das letras continua a nortear os estudos do campo. Em sua maioria, mas com relevantes exceções, as pesquisas sobre música popular, dentro da nossa periodização, não dispensaram maior atenção aos aspectos sonoros propriamente ditos. Especialmente no caso dos primeiros estudos, constituía já uma grande novidade que um objeto, até então desconsiderado pela historiografia acadêmica, fosse o tema de pesquisas, artigos e ensaios.

Estiveram em foco na análise da metodologia, as relações e tensões entre a história e as musicologias. Inicialmente foi traçado um breve histórico das musicologias, destacando seus objetos, teorias, métodos e o processo de institucionalização do campo, com o objetivo de oferecer elementos para a compreensão de sua dinâmica atual e localizar historicamente o "cisma" entre Musicologia e Etnomusicologia. A seguir, foram apresentadas algumas reflexões acerca da interação entre "história da música" e "música como documentação historiográfica", uma interseção que está presente na expressão atualmente corrente História e Música. 
Foram analisadas as relações entre análise técnico-estética da música e abordagens histórico-sociológicas, destacando que, a partir da superação da metodologia baseada na análise das letras das canções, duas tendências se delinearam: uma historiografia que se desenvolvia sem incorporar o estudo da linguagem musical e as vertentes que procuram, em diferentes planos, incorporar os aspectos sonoros.

Tomada em seu conjunto, pode-se perceber uma gradação nas abordagens da história da música entre leituras mais voltadas para aspectos de estruturação musical, de um lado, e abordagens sócio-político-culturais, de outro. Também se pode fazer uma distinção, talvez mais acentuada no caso da música popular, entre uma historiografia que toma a música como objeto principal da pesquisa histórica e aquela que utiliza a música como fonte documental privilegiada para estudos de outros objetos e compreensão de outros fenômenos. Assim, é um horizonte colocado para a historiografia da música considerar conjuntamente, numa visão integrada e de maneira articulada, este leque de questões que envolvem a música enquanto objeto de cultura, ideal que parece inatingível por limitações individuais e metodológicas. Em relação a esta questão fundamental, a posição desenvolvida nesta tese é a de considerar complementares as distintas abordagens, uma vez que se reconhece a impossibilidade de uma história da música universal e totalizante, e pontuar a dificuldade de separar a discussão puramente epistemológica das disputas de competências e legitimidades inerentes ao campo científico.

Nesta tese, foi analisada a produção historiográfica realizada nos estados de São Paulo e Rio de Janeiro até o final do século XX. Até esse momento, estes estados concentravam a imensa maioria da produção nacional. Desde então, a realização de dissertações e teses sobre música popular cresceu significativamente do ponto de vista quantitativo e em sua distribuição pelo país, o que reflete a consolidação do objeto na disciplina e sua presença nos novos programas de pós-graduação em História. Este crescimento pode ser também localizado nas publicações em livros e revistas especializadas e na participação em eventos acadêmicos. Certamente, a pesquisa histórica cresceu também do ponto de vista qualitativo, com o amadurecimento intelectual dos pesquisadores que realizaram as pesquisas em foco neste estudo, e com a entrada no campo de muitos novos pesquisadores que se nutriram das elaborações 
oferecidas pela geração anterior. Muitos dos autores estudados nesta tese são orientadores de novas pesquisas, seus trabalhos são citados, os autores, temas, questões e elaborações dialogam, o que tende a elevar a compreensão dos fenômenos em foco. Caracteriza-se assim, a constituição e afirmação de um campo de estudos inscrito nas Ciências Humanas e, particularmente, na História. 


\section{REFERÊNCIAS}

\section{DISSERTAÇõES E TESES}

ABONIZIO, Juliana. O protesto dos inconscientes: Raul Seixas e micropolítica. Dissertação de mestrado em História. Assis: FCL-UNESP, 1999.

. A chave da Sociedade Alternativa. Tese de doutorado em Sociologia. Araraquara: FCL-UNESP, 2005.

ANTUNES, Gilson Uehara. Américo Jacomino "Canhoto" e o desenvolvimento da arte solística do violão na cidade de São Paulo. Dissertação de mestrado. São Paulo: ECA-USP, 2003.

ARAUJO, Paulo César de. Eu não sou cachorro não: memória da canção popular "cafona" (1968-1978). Dissertação de mestrado em Memória Social e Documento. Rio de Janeiro: UNIRIO, 1999.

AUGUSTO, Paulo Roberto Peloso. Tangos brasileiros, Rio de Janeiro: 1870 / 1920. Tese de doutorado em História. São Paulo: FFLCH-USP, 1996.

AVANCINI, Maria Marta Picarelli. Nas tramas da fama: as estrelas do rádio em sua época áurea, Brasil, anos 40 e 50. Dissertação de mestrado em História. Campinas: IFCH/UNICAMP, 1996.

BAIA, Silvano Fernandes. A pesquisa sobre música popular em São Paulo. Dissertação de mestrado em Música. São Paulo: IA-UNESP, 2005.

BARBOSA, André Luís Gardel. O encontro entre Bandeira \& Sinhô. Dissertação de mestrado em Letras. Rio de Janeiro: UFRJ, 1995.

. Aproximações e fugas: a letra do poema e a letra da canção popular brasileira.

Tese de doutorado em Letras. Rio de Janeiro: UFRJ, 2002.

BARROS, Orlando de. Custódio Mesquita, um compositor romântico: o entretenimento, a canção sentimental e a política no tempo de Vargas (1930-1945). Tese de doutorado em História. São Paulo: FFLCH-USP, 1995.

BARTOLONI Giácomo. O Violão na cidade de São Paulo no período de 1900 a 1950. Dissertação de mestrado em Artes. São Paulo: IA-UNESP, 1995.

Violão: a imagem que fez escola. São Paulo, 1900-1960. Assis: FCL-UNESP, 2000.

BORGES, Beatriz. Samba-canção, fratura e paixão: uma linguagem diante do espelho. Dissertação de mestrado em Letras. Rio de Janeiro: PUC-Rio, 1980. 
CALDAS, Waldenyr. Acorde na aurora: música sertaneja e indústria cultural. Dissertação de mestrado em Sociologia. São Paulo: FFLCH-USP, 1976.

CALDEIRA NETO, Jorge dos Santos. Voz macia: o samba como padrão de música popular brasileira - 1917/1939. Dissertação de mestrado em Sociologia. São Paulo: FFLCH-USP, 1989.

CARMO Jr., José Roberto do. Melodia \& prosódia: Um modelo para a interface músicafala com base no estudo comparado do aparelho fonador e dos instrumentos musicais reais e virtuais. Tese de doutorado em Linguística. São Paulo: FFLCH-USP, 2007.

CARVALHO, Luiz Fernando Medeiros de. A jura e o critério da platéia no samba de Ismael Silva. Dissertação de mestrado em Letras. Rio de Janeiro: PUC-Rio, 1978.

CHAMMÉ, Sebastião Jorge. Fonemas e vocábulos musicais no comportamento psicosocial. Dissertação de mestrado em Sociologia. São Paulo: Escola de Sociologia e Política, 1973.

CONTIER, Arnaldo Daraya. Brasil Novo: música, nação e modernidade. Os anos 20 e 30. Tese de livre docência. São Paulo: FFLCH-USP, 1988.

DIAS, Márcia Regina Tosta. Sobre mundialização da indústria fonográfica: Brasil - anos 70-90. Dissertação de mestrado em Sociologia. Campinas: IFCH/UNICAMP, 1997.

DREHMER, Carlos Edmundo Chenaud. Violão, violonistas e memória social nas décadas de 50 e 60 em Salvador. Dissertação de mestrado em História. São Paulo: PUC-SP, 1999.

ESTEPHAN, Sérgio. O violão instrumental brasileiro: 1884-1924. Dissertação de mestrado em História. São Paulo: PUC-SP, 1999.

Viola, minha viola: a obra violonística de Américo Jacomino, o Canhoto (1889-1928), na cidade de São Paulo. Tese de doutorado em História, São Paulo: PUC-SP, 2007.

FAVARETTO, Celso Fernando. Tropicália: alegoria, alegria. Tese de doutorado em Filosofia. São Paulo: FFLCH-USP, 1978.

FERNANDES, Dmitri Cerboncini. A inteligência da música popular: a "autenticidade" no samba e no choro. Tese de doutorado em Sociologia. São Paulo: FFLCH-USP, 2010.

FIALHO, Carmela Roseli Palmieri Parente. Tropicália ou Panis et Circencis: no país do Rei da Vela. Dissertação de mestrado em História. Rio de Janeiro: UFRJ, 1994.

FURTADO FILHO, João Ernani. O combate ao samba e o samba de combate: música, guerra e política, 1930-1940. Dissertação de mestrado em História. São Paulo: PUC/SP, 1998.

. Um Brasil brasileiro: música, política, brasilidade (1930-1945). Tese de doutorado em História, São Paulo: FFLCH-USP, 2004. 
GARCIA, Tânia da Costa. $O$ "it" verde amarelo de Carmem Miranda. Tese de doutorado em História. São Paulo: FFLCH-USP, 2000.

GARCIA, Walter. Bim bom: a contradição sem conflitos de João Gilberto. Dissertação de mestrado em Letras. São Paulo: FFLCH-USP, 1998.

. Melancolias, mercadorias: Dorival Caymmi, Chico Buarque, o pregão de rua e a canção popular-comercial no Brasil. Tese de doutorado em Letras. USP, 2005.

GOLDFEDER, Miriam. Manipulação e participação: a Rádio Nacional em debate. Dissertação de mestrado em Ciência Política. Campinas: IFCH/UNICAMP, 1977.

GOLDWASSER, Julia. O Palácio do samba: estudo antropológico da Escola de Samba Estação Primeira de Mangueira. Dissertação de mestrado em Antropologia. Rio de Janeiro: UFRJ, 1975.

GOMES, Tiago de Melo. Lenço no pescoço: o malandro no teatro de revista e na música popular - "nacional", "popular" e cultura de massas nos anos 1920. Dissertação de mestrado em História. Campinas: IFCH-UNICAMP, 1998.

HONÓRIO FILHO. Wolney. O sertão nos embalos da música rural 1929-1950. Dissertação de mestrado em História. São Paulo: PUC/SP, 1992.

No ar: amores amáveis. Um estudo sobre a produção do amor na música brasileira 1951-1958. Dissertação de mestrado em História. São Paulo: PUC-SP, 1998.

HORI, Ieda Marques Britto. Samba na cidade de São Paulo (1900-1930): contribuição ao estudo da resistência e da repressão cultural. Dissertação de mestrado em Ciência Sociais. São Paulo: FFCLH-USP, 1981.

IKEDA, Alberto Tsuyoshi. Música na cidade em tempo de transformação. São Paulo: 1900-1930. Dissertação de mestrado em Artes. São Paulo: ECA-USP, 1988.

Música política: imanência do social. Tese de doutorado em Comunicação. São Paulo: ECA-USP, 1995.

JAMBEIRO, Othon. Canção popular e indústria cultural. Dissertação de mestrado em Sociologia. São Paulo: FFLCH-USP, 1971.

JOSÉ, Camen Lucia. “...isto é 'brega"': Isto é brega. Dissertação de mestrado em Comunicação. São Paulo: ECA-USP, 1991.

LAMARÃO, Luisa Quarti. As muitas histórias da MPB: as idéias de José Ramos Tinhorão. Dissertação de mestrado em História. Niterói: UFF, 2008.

LENHARO, Alcir. No fim da estrada: a trajetória artística de Nora Ney e Jorge Goulart no tempo dos cantores do rádio. Tese de livre docência. Campinas: UNICAMP, 1992. 
LEOPOLDI, José Sávio. Escola de samba, ritual e sociedade. Dissertação de mestrado em Antropologia. Rio de Janeiro: UFRJ, 1975.

LÉVY, Julia. A pauta da ilusão: um estudo antropológico da música popular brasileira. Dissertação de mestrado em Antropologia. Rio de Janeiro: UFRJ, 1977.

LIMA, José Edson Schümann. Brutalidade e jardim: as imagens da nação da tropicália. Dissertação de mestrado em História. Rio de Janeiro: UFRJ, 1997.

MACHADO, Cacá. O enigma do homem celebre: ambição e vocação de Ernesto Nazareth (1863-1934) - música, história e literatura. Tese de doutorado em Letras. São Paulo: FFLCH-USP, 2005.

MASCARENHAS, Lícia Gomes. A dama da boêmia: imagens de Chiquinha Gonzaga. Dissertação de mestrado. Niterói: UFF, 1999.

MATOS, Cláudia Neiva de. $O$ malandro no samba: uma linguagem de fronteira.

Dissertação de mestrado em Letras. Rio de Janeiro: PUC-Rio, 1981.

MATTA, Gildeta Matos da. Samba, marginalidade e ascensão. Dissertação de mestrado em Filosofia. Rio de Janeiro: UFRJ, 1981.

MENESES, Adélia Bezerra de. Desenho Mágico: estudo quase acadêmico sobre Francisco Buarque de Hollanda, dito Chico. Tese de doutorado em Letras. São Paulo: FFLCH-USP, 1980.

MILlAN, Cleusa de Souza. Chiquinha Gonzaga no Rio de Janeiro da "Belle Époque": um ensaio da memória. Dissertação de mestrado em Memória Social e Documento. Rio de Janeiro: UNIRIO, 1996.

MOBY, Alberto. Sinal fechado: a música popular brasileira sob censura (1937-45/196978). Dissertação de mestrado em História. Niterói: UFF, 1993.

MONTANARI, Marilena Esberard de Lauro. O poema canto gerado na dialética: música popular x texto literário. Dissertação de mestrado em Comunicação. São Paulo: PUC/SP, 1980.

MORAES. José Geraldo Vinci de. As sonoridades paulistanas: a música popular na cidade de São Paulo. Final do séc. XIX ao início do XX. Dissertação de mestrado em História. São Paulo: PUC/SP, 1989.

. Metrópole em sinfonia: história, cultura e música popular em São Paulo nos anos 30. Tese de doutorado em História. São Paulo: FFLCH-USP, 1997.

MORELLI. Rita de Cássia Lahoz. Indústria fonográfica: relações sociais de produção e concepção acerca da natureza do trabalho artístico (um estudo antropológico: a indústria do disco no Brasil e a imagem pública de dois compositores-intérpretes de MPB na década de 70). Dissertação de mestrado em Antropologia. Campinas: IFCHUNICAMP, 1988. 
MUKUNA, Kazadi Wa. O contato musical transatlântico: contribuição Bantu na música popular brasileira. Tese de doutorado em sociologia. São Paulo: FFLCH-USP, 1977.

NAPOLITANO, Marcos. Seguindo a canção: engajamento político e indústria cultural na trajetória da música popular brasileira (1959-1969). Tese de doutorado em História. São Paulo: FFLCH-USP, 1999.

NASCIMENTO, Antonio Adriano. A influência da habanera nos tangos de Ernesto Nazareth. Dissertação de mestrado em Artes. São Paulo: ECA-USP, 1990.

NAVES, Santuza Cambraia. Objeto não identificado: a trajetória de Caetano Veloso. Dissertação de mestrado em Antropologia. Rio de Janeiro: UFRJ, 1988.

O violão azul: modernismo e música popular. Tese de doutorado em Sociologia. Rio de Janeiro: Instituto Universitário de Pesquisas do Rio de Janeiro, 1997.

NORONHA, Miriam Porto. Dimensões da vida urbana sob o olhar de Chico Buarque. Dissertação de mestrado em História. São Paulo: PUC-SP, 1994 .

OLIVEIRA, Allan de Paula. Miguilim foi pra cidade ser cantor: uma antropologia da música sertaneja. Tese de doutorado em Antropologia. Florianópolis: UFSC, 2009.

OLIVEIRA, Cláudia Maria Silva de. Quando canta o Brasil: a Rádio Nacional e a construção de uma identidade popular (1936-1945). Dissertação de mestrado em História. Rio de Janeiro: PUC-Rio, 1996.

OLIVEIRA. Fátima Amaral Dias de. Trilha sonora: topografia semiótica paulistana nas canções independentes das décadas de setenta e oitenta. Dissertação de mestrado em História. Campinas: IFCH-UNICAMP, 1990.

OLIVEIRA. José Luiz de. Uma estratégia de controle: a relação do poder do estado com as Escolas de Samba do Rio de Janeiro no período de 1930 a 1985 . Dissertação de mestrado em História. Rio de Janeiro: UFRJ, 1989.

OLIVEIRA, Laerte Fernandes. Em um porão de São Paulo: o Lira Paulistana e a produção alternativa. Dissertação de mestrado em Ciências Sociais. São Paulo: PUC-SP, 1999.

OSWARD, Christina. Banho de lua: o rock nacional de Celly Campello a Caetano Veloso. Dissertação de mestrado em História. Rio de Janeiro: PUC-Rio, 1998.

PAIANO, Enor. Berimbau e o som universal: lutas culturais e indústria fonográfica nos anos 60. Dissertação de mestrado em Comunicação. São Paulo: ECA-USP, 1994.

PARANHOS, Adalberto. $O$ roubo da fala: origens da ideologia do trabalhismo no Brasil. Dissertação de mestrado em Ciência Política. Campinas: IFCH-UNICAMP, 1997.

. Os desafinados: sambas e bambas no "Estado Novo". Tese de doutorado em História. São Paulo: PUC-SP, 2005. 
PEDERIVA, Ana Barbara Aparecida. Jovens tardes de guitarras sonhos e emoções: fragmentos do movimento musical Jovem Guarda. Dissertação de mestrado em História. São Paulo: PUC-SP, 1998.

Anos dourados ou rebeldes: juventude, territórios, movimentos e canções nos anos 60. Tese de doutorado em Antropologia, PUC-SP, 2004.

PEREIRA, João Baptista Borges. Côr, profissão e mobilidade: o negro e o rádio de São Paulo. Tese de doutorado em Antropologia. São Paulo: FFLCH-USP, 1966.

PEREIRA, Maria Helena Gisela Ferrari Gomes. Samba: do lazer aos mass media. Dissertação de mestrado em Comunicação. Rio de Janeiro: UFRJ, 1979.

PEREIRA, Simone Luci. Bossa Nova é sal, é sol, é sul: música e experiências urbanas (Rio de Janeiro, 1954-1964). Dissertação de mestrado em História. São Paulo: PUC-SP, 1998.

PUTERMAN, Paulo Marcos. Choro: a construção de um estilo musical. Dissertação de mestrado em Sociologia. São Paulo: FFLCH-USP, 1985.

Indústria cultural: indústria ou cultura? Tese de doutorado em Sociologia. São Paulo: FFLCH-USP, 1993.

RIBEIRO, Ana Maria Rodrigues. Samba negro, espoliação branca: um estudo das escolas de samba do Rio de Janeiro. Dissertação de mestrado em Ciências Sociais. São Paulo: FFLCH-USP, 1981.

SALVADORI, Maria Ângela Borges. Capoeiras e malandros: pedaços de uma sonora tradição popular (1890-1950). Dissertação de mestrado em História. Campinas: IFCHUNICAMP, 1990.

SANCHES JUNIOR, Nelson Martins. Ponteio da cidade: música caipira e identidade social. Dissertação de mestrado em História. Assis: FCL-UNESP, 1997.

SILVA, Anazildo Vasconcelos da. A expressão subjetiva como fundamento da significação na poesia de Chico Buarque. Dissertação de mestrado em Letras. Rio de Janeiro: UFRJ, 1973.

SILVA, Antonio Gomes da. Luiz Gonzaga: o migrante nordestino na música popular brasileira. Tese de doutorado em História. São Paulo: FFLCH-USP, 1986.

SILVA, Elizete Mello da. A jovem guarda e os anos 60: uma festa de arromba. Dissertação de mestrado em História. Assis: FCL-UNESP, 1996.

. Indústria Cultural e Música Popular Brasileira nos anos 70. Tese de doutorado em História. Assis: FCL-UNESP, 2001.

SILVA, Raimundo Dalvo da Costa. Cotidiano, memória e tensões: a trajetória artística das cantoras do rádio de Salvador de 1950 a 1964. Dissertação de mestrado em História. São Paulo: PUC-SP, 1999. 
SNYDER, Randy L. College jazz education during the 1960: its development and acceptance. PhD Thesis. University of Houston, USA, 1999.

STROUD, Sean. Disco é cultura: MPB and the defense of tradition in Brazilian popular music. PhD Thesis. University of London. 2005.

TATIT, Luiz. Por uma semiótica da canção popular. Dissertação de mestrado em Linguística. São Paulo: FFLCH-USP, 1982.

. Elementos semióticos para uma tipologia da canção popular brasileira. Tese de doutorado em Linguística. São Paulo: FFLCH-USP, 1986.

Semiótica da canção: fundamentos para uma construção do sentido melódico e lingüístico. Tese de Livre Docência. São Paulo: FFLCH-USP, 1994.

TOTA, Antonio Pedro. Samba da legitimidade. Dissertação de mestrado em História. São Paulo: FFLCH-USP, 1980.

A locomotiva no ar: rádio na cidade de São Paulo (1924/1934). Tese de doutorado em História. São Paulo: FFLCH-USP, 1987.

ULHÔA, Martha Tupinambá de. Música popular in Montes Claros, Minas Gerais, Brazil: a study of middle-class popular music aesthetics in the 1980s. PhD Thesis. Nova York: Cornell University, 1991.

VIANNA, Hermano. A descoberta do samba: música popular e identidade nacional. Tese de doutorado em Antropologia. Rio de Janeiro: UFRJ, 1994.

VILARINO, Ramon Casas. A MPB em movimento: música, festivais e censura (1965 1969). Dissertação de mestrado em História. São Paulo: PUC-SP, 1998.

WASSERMAN, Maria Clara. Abre a cortina do passado: a Revista de Música Popular e o pensamento folclorista (Rio de Janeiro: 1954-1956). Dissertação de mestrado em História. Curitiba: UFPR, 2002.

WISNIK, José Miguel. A música em torno da Semana de Arte Moderna. Dissertação de mestrado em Letras. São Paulo: FFLCH-USP, 1974.

. Dança dramática (poesia / música brasileira). Tese de doutorado em Letras. São Paulo: FFLCH-USP, 1979.

ZAN, José Roberto. Do fundo de quintal à vanguarda: contribuição para uma história social da música popular brasileira. Tese de doutorado em Sociologia. Campinas: IFCH/UNICAMP, 1996.

ZERON, Carlos Alberto de Moura Ribeiro. Fundamentos histórico-políticos da música nova e da música engajada no Brasil a partir de 1962: o salto do tigre de papel. Tese de doutorado. São Paulo: FFLCH-USP, 1991. 


\section{B I B L I O G R A F I A}

ADORNO, T. W. O fetichismo na música e a regressão da audição. In: Os Pensadores: Benjamin, Habermas, Horkheimer e Adorno. 2º ed. São Paulo: Abril, 1983, p.165-191. . Idéias para a sociologia da música. In: Os Pensadores: Benjamin, Habermas, Horkheimer e Adorno. 2º ed. São Paulo: Abril, 1983, p.259-268.

A indústria cultural. In: COHN, Gabriel (org). Theodor W. Adorno. São Paulo: Ática, Grandes Cientistas Sociais no 54, 1986, p.92-99.

. Sobre música popular. In: COHN, Gabriel (org). Theodor W. Adorno. São Paulo:

Ática, Grandes Cientistas Sociais no 54, 1986, p.115-146.

Moda intemporal: sobre o jazz. In: Prismas. São Paulo: Ática, 1998, p.117-130.

ADORNO, T. W.; HORKHEIMER, M. A indústria cultural: o esclarecimento como mistificação das massas. In: Dialética do Esclarecimento. São Paulo: Zahar, 1985.

ALMEIDA, Renato. História da música brasileira. $2^{\mathfrak{a}}$ ed. Rio de Janeiro: F. Briguiet \& Comp. Editores, 1942.

Folclore. Rio de Janeiro: FUNARTE, 1976.

ALMIRANTE (Henrique Foréis Domingues). No tempo de Noel Rosa. São Paulo:

Francisco Alves, 1963.

ALVARENGA, Oneyda. Música popular brasileira. São Paulo: Globo, 1950.

ANDERSON, Benedict. Nação e consciência nacional. São Paulo: Editora Ática, 1989.

ANDERSON, Perry. Considerações sobre o marxismo ocidental. $2^{\text {a }}$ ed. São Paulo: Editora Brasiliense, 1989.

ANDRADE, Mário de. Aspectos da música brasileira. Belo Horizonte: Villa Rica Editora, 1991.

. Ensaio sobre a música brasileira. São Paulo: Livraria Martins, 1972. Primeira edição: São Paulo: I. Chiarato \& Cia., 1928.

. Música, doce música. Belo Horizonte: Itatiaia Editora, 2006.

ARAÚJO, Paulo Cesar de. Eu não sou cachorro não: música popular cafona e ditadura militar. 4a ed. Rio de Janeiro: Editora Record, 2003.

. Roberto Carlos em Detalhes: Editora Planeta do Brasil, 2006. 
ARTCULTURA. Revista de História, Cultura e Arte. Publicação do Instituto de História da Universidade Federal de Uberlândia. Uberlândia: nº9, 2004 e no 13, 2006.

ASSIS, Machado de. Um homem célebre. Publicado originalmente na Gazeta de Notícias em 1888 e republicado em Várias Histórias, Rio de Janeiro: Laemmert \& C. Ed., 1896. Disponível em: <http://machado.mec.gov.br/arquivos/html/contos/macn005.htm>.

AZEVEDO, Miguel Ângelo de (Nirez) et all. Discografia brasileira (78rpm - 1902/1964). Rio de Janeiro: FUNARTE, 1982.

BARBOSA, Orestes. Samba: sua história, seus poetas, seus músicos e seus cantores. Rio de Janeiro: FUNARTE, 1978.

BAKHTIN, Mikhail. A cultura popular na Idade Média e no Renascimento: o contexto de François Rebelais. São Paulo: Hucitec. 4ª ed., 1999.

BENJAMIN, Walter. A obra de arte na época de suas técnicas de reprodução. In: LIMA, Luiz Costa. Teoria da Cultura de Massa. 7aㅡ Ed. São Paulo: Paz e Terra, 2005.

BÉHAGUE, Gerard. Biblioteca da Ajuda (Lisbon) Mss 1595 / 1596: two EighteenthCentury anonymous collections of modinhas. Texas: University of Texas Press. Anuario, Vol. 4, 1968, pp. 44-81.

Música "erudita”, "folclórica" e "popular" do Brasil: Interações e inferências para a musicologia e a etnomusicologia modernas. Latin American Music Review, v.27, noㅡㄴ, 2006.

. Perspectivas atuais na pesquisa musical e estratégias analíticas da Música Popular Brasileira. Latin American Music Review, Volume 27, no 1, 2006, pp. 69-78

BELLINATI, Paulo. The guitar works of Garoto (Annibal Augusto Sardinha). 2 vols. San Francisco, USA: Guitar solo pulbications.

BERGERON, Katherine; BOHLMAN, Philip. (eds.) Disciplining Music: musicology and its canons. The University of Chicago Press, 1992.

BLACKING, John. How musical is man? Seattle: University of Washington Press, 1973.

BLOOM, Harold. O cânone ocidental: os livros e a escola do tempo. Rio de Janeiro: Editora Objetiva, 2001. Titulo original: The Western canon: the books and the school of the ages, 1994.

BOHLMAN, Philip. Ethnomusicology's Challenge to the Canon; the Canon's Challenge to Ethnomusicology. In: BERGERON, Katherine; BOHLMAN, Philip. (eds.) Disciplining Music: musicology and its canons. The University of Chicago Press, 1992, p.116-136

BOURDIEU, Pierre. A Economia das trocas simbólicas. Introdução, organização e seleção de Sérgio Miceli. 5ª ed. São Paulo: Perspectiva, 2004. Primeira edição em 1974. 
Razões Práticas: sobre a teoria da ação. Tradução de Mariza Corrêa. 4⿳a ed. Campinas, SP: Papirus, 1996.

. 0 campo científico. Tradução de Paula Montero. In: ORTIZ, Renato (org.). Pierre Bourdieu. Coleção Grandes Cientistas Sociais. São Paulo: Ática, 1983a, p.122-155.

. Algumas propriedades dos campos. In: Questões de sociologia. Rio de Janeiro: Marco Zero, 1983b. p.89-94.

. A Distinção: crítica social do julgamento. São Paulo: Edusp; Porto Alegre: Zouk, 2007. Titulo original: La distinction: critique sociale du jugement, 1979.

BURKE, Peter. A Cultura Popular na Idade Moderna. Europa, 1500-1800. São Paulo: Editora Schwarcz, 1989.

. O que é História Cultural? Rio de Janeiro: Zahar, 2005.

CABRAL, Sérgio. As Escolas de Samba: o que, quem, como, quando e por quê. Rio de Janeiro: Editora Fontana, 1974.

Pixinguinha: vida e obra. Rio de Janeiro: FUNARTE, 1978

No tempo do Almirante: uma história do rádio e da MPB. Rio de Janeiro: Francisco Alves, 1990.

As Escolas de Samba do Rio de Janeiro. Rio de Janeiro: Lumiar, 1996.

CALDAS, Waldenyr. Acorde na Aurora: música sertaneja e indústria cultural. São Paulo: Editora Nacional, 1977.

CÂMARA, Renato Phaelante. Capiba é frevo meu bem. Rio de Janeiro: FUNARTE, 1986.

CAMINHA, Pero Vaz de. Carta a El Rei D. Manuel. São Paulo: Dominus, 1963. Disponível em: <http://www.dominiopublico.gov.br/download/texto/bv000292.pdf>

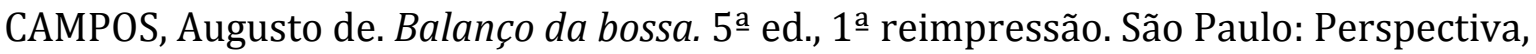
2003. Primeira edição, 1968.

As Antenas de Ezra Pound. In: POUND, Ezra. $A B C$ da Literatura. 11a ed. São Paulo: Cultrix, 2006, pp. 9-14.

CAMPOS, Augusto de; CAMPOS, Haroldo de. Panorama do Finnegans Wake. 4⿳a ed.. São Paulo: Perspectiva, 2001.

CAMPOS. Alice Duarte Silva de. Um certo Geraldo Pereira. Rio de Janeiro: FUNARTE, 1983.

CANCLINI, Néstor Garcia. Culturas híbridas estratégias para entrar e sair da modernidade. São Paulo: EDUSP, 1998. 
CANDIDO, Antonio. Literatura e sociedade: estudos de teoria e história literária. São Paulo: Companhia Editora Nacional, 1965.

Dialética da malandragem: caracterização das Memórias de um Sargento de Milícias. Revista do Instituto de Estudos Brasileiros, no 8. São Paulo: USP, 1970, pp. 6789.

Formação da literatura brasileira: momentos decisivos 1750-1880. 12ª ed. São Paulo/Rio de Janeiro: FAPESP/Ouro sobre azul, 2009. Primeira publicação em 1957.

CARDOSO, Ciro Flamarion; VAINFAS, Ronaldo (orgs.). Domínios da História: ensaios de teoria e metodologia. Rio de Janeiro: Campus, 1997.

CARNEIRO, Edison. Capoeira. Rio de Janeiro: FUNARTE, 1975.

CASCUDO, Luís da Câmara. Mitos brasileiros. Rio de Janeiro: FUNARTE, 1976.

CASTRO, Hebe. História Social. In: CARDOSO, Ciro Flamarion; VAINFAS, Ronaldo (orgs.). Domínios da História: ensaios de teoria e metodologia. Rio de Janeiro: Campus, 1997.

CASTRO, Ruy. Chega de saudade: a história e as histórias da Bossa Nova. São Paulo: Companhia das Letras, 1990.

CERTEAU, Michael de. A invenção do cotidiano. 9a ed. Petrópolis: Editora Vozes, 2003. Titulo original: L'invention du quotidien, 1980.

CHALMERS, Alan F. O que é ciência afinal? Título original: What is this called science? São Paulo: Brasiliense, 1993

CHARTIER, Roger. A História Cultural: entre práticas e representações. Algés, Portugal: Diefel Editorial, 1990.

CHIMÈNES, Myriam. Musicologia e História: fronteiras ou "terra de ninguém" entre duas disciplinas? In: REVISTA DE HISTÓRIA. Departamento de História da FFLCH-USP. São Paulo: Humanitas/FFLCH-USP, no 157, 2º semestre de 2007, pp. 15-29.

CLAVER FILHO, José. Waldemar Henrique: o canto da Amazônia. Rio de Janeiro: FUNARTE, 1978.

COLLIER, James Lincoln. Jazz: a autêntica música americana. Rio de Janeiro: Zahar, 1995.

CONTIER, Arnaldo Daraya. Música e ideologia no Brasil. São Paulo: Novas Metas, 1985.

. História e música. Revista de História. São Paulo: FFLCH/USP, no 119 (nova série), p. 69-89, 1988. 
. Música no Brasil: História e interdisciplinaridade. Algumas interpretações (19261980). In: Revista História em Debate. Anais do XVI Simpósio da ANPUH, 1991, pp. 151189.

. Edu Lobo e Carlos Lyra: o nacional e o popular na canção de protesto (os anos 60). São Paulo: Revista Brasileira de História, vol. 18, n. 35, 1998.

COOK, Nicholas. Agora somos todos (etno)musicólogos. Título original: We are all (Ethno)musicologists now. Ictus. UFBA, no 7, 2006. Tradução de Pablo Sotuyo Blanco. Disponível em <www.ictus.ufba.br $>$

COOK, Nicholas; EVERIST, Mark. Rethinking Music. Oxford University Press, 1999

DAHLHAUS, Carl. Fundamentos de la historia de la música. Barcelona: Gedisa, 2003. Título original em alemão: Grundlagen der Musikgeschichte, 1997.

DIAS, Márcia Tosta. Os donos da voz: Indústria fonográfica brasileira e mundialização da cultural. São Paulo: Boitempo Editorial, 2000.

DIDIER, Carlos; MÁXIMO, João. Noel Rosa: uma biografia. Linhas Gráficas Editora/ Editora da UNB, 1990.

EAGLETON, Terry. Ideology: an introduction. London / New York: Verso, 1991.

ECO, Umberto. Apocalípticos e Integrados. Tradução de Pérola de Carvalho. 6a ed. São Paulo: Perspectiva, 2004. 1ํㅡㄹ., 1970. Título original: Apocalittici e Integrati. Milano: Bompiani, 1964.

Obra Aberta. 9ạ Ed. São Paulo: Perspectiva, 2007.

EDMUNDO, Luis. O Rio de Janeiro de meu tempo. Brasília: Edições do Senado Federal, 2003. Disponível em <www.dominiopublico.gov.br>

EFEGÊ, Jota. (João Gomes Ferreira). Figuras e coisas da música popular brasileira. Rio de Janeiro, FUNARTE, v.1 1978, v.2 1980.

Meninos, eu vi. Rio de Janeiro: FUNARTE, 1985.

ELIAS, Norbert. Mozart, sociologia de um gênio. Rio de Janeiro: Zahar, 1995.

MARX, Karl; ENGELS, Friedrich. Manifesto do Partido Comunista. Disponível em: $<$ www.dominiopublico.gov.br>. Acesso em: 17 out 2010.

ENTRE A HISTÓRIA E A MEMÓRIA DA MÚSICA. Banco de dados. Coordenador: José Geraldo Vinci de Moraes. Disponível em: < www.memoriadamusica.com.br >. Diversos acessos em 2010.

FABBRI, Franco. A theory of musical genres: two applications. In: Popular Music Perspectives 2, p.501-507, HORN and TAGG (eds.). Göteborg and Exeter, 1985. 
FALCON, Francisco. História e poder. CARDOSO, Ciro Flamarion; VAINFAS, Ronaldo (orgs.). Domínios da História: ensaios de teoria e metodologia. Rio de Janeiro: Campus, 1997.

FFLCH-USP. Programa de Pós-Graduação em História Social. Apresentação do programa. Disponível em:

<www.fflch.usp.br/dh/pos/hs/index.php?option=com_content\&view=article\&id=1\&Ite mid=18> . Acesso em: 11 out. 2010.

FRANCESCHI, Humberto. A casa Edson e seu tempo. Rio de Janeiro: Sarapuí, 2002.

FUBINI, Enrico. La estética musical desde la Antigüedad hasta el siglo XX. Madrid: Alianza Editorial, 1996. Títulos originais em italiano: L'estetica musicale dall'antichità al Settecento y L'estetica musicale dal Settecento a oggi, 1976.

GALVÃO, Walnice Nogueira. MMPB, uma análise ideológica. In Saco de gatos: ensaios críticos. São Paulo, Livraria Duas Cidades, pp. 93-119, 1976. Publicado originalmente na Revista Aparte, no. 2, maio-junho, 1968.

GARCIA, Tânia da Costa. $O$ "it" verde amarelo de Carmen Miranda (1930-1946). São Paulo: Annablume/FAPESP, 2004.

. Reconfigurações identitárias, meios de comunicação de massa e cultura jovem na América Latina na segunda metade do século XX. In: BARBOSA; GARCIA. (orgs.). Cadernos de Seminários de Pesquisa: Cultura e Políticas nas Américas. Vol. 1. Assis: FCL/Assis-Unesp Publicações, 2009.

GINZBURG, Carlo. O queijo e os vermes: o cotidiano e as idéias de um moleiro perseguido pela Inquisição São Paulo: Companhia das Letras, 1987. Título original: l formaggio e i vermi: Il cosmo di un mugnaio del '500, 1976.

Mitos, emblemas, sinais: morfologia e história. Companhia das Letras, 1989. Mitti emblemi spie: morfologia e storia, 1986.

GIRON, Luís Antônio. A vocação de criticar. Entrevista com Caetano Veloso. Revista Época, no 390, nov. 2005. Disponível em <http://revistaepoca.globo.com/Revista/Epoca/0,EDG72153-6011,00A+VOCACAO+DE+CRITICAR.html>. Acesso em 16.05.2008.

GOLDFEDER, Miriam. Por trás das ondas da Rádio Nacional. Rio de Janeiro, Paz e Terra, 1980.

GOMES, Bruno. Custódio Mesquita: prazer em conhecê-lo. Rio de Janeiro: FUNARTE, 1986.

GOMES, Tiago de Melo. Estudos acadêmicos sobre a música popular brasileira: levantamento bibliográfico e comentário introdutório. In: História: questões \& debates. Curitiba, PR: Editora da UFPR, ano 16, n.ํ 31, 1999, p.95-111. 
GONZÁLES, Juan Pablo. Musicología popular en América Latina: síntesis de sus logros, problemas y desafíos. Revista Musical Chilena, no 195, p.38-64, janeiro-junho, 2001.

GONZÁLES, Juan Pablo; ROLLE, Claudio. Historia Social de la música popular em Chile, 1890-1950. Santiago: Ed. Universidad Católica e Casa de las Américas, 2005.

GRAMSCI, Antonio. Os intelectuais e a organização da cultura. 2 ed. Rio de Janeiro: Civilização Brasileira, 1978.

Literatura e vida nacional. 2ª ed. Rio de Janeiro: Civilização Brasileira. 1978.

GROUT, Donald; PALISCA, Claude. História da música ocidental. Título original: A History of Western Music. Tradução de Ana Luísa Faria. Lisboa: Gradiva Publicações, 1994.

GROUT, Donald; PALISCA, Claude; BURKHOLDER, J. Peter. A History of Western music. 8th ed. New York: W.W Norton \& Company, 2010.

GUIMARÃES, Antonio Sérgio Alfredo. Democracia Racial. Disponível em: <www.fflch.usp.br/sociologia/asag/Democracia\%20racial.pdf>. Acesso em: 17 out. 2010.

GUIMARÃES, Francisco (Vagalume). Na roda de samba. Rio de Janeiro: MEC / FUNARTE, 1978.

HAMM, Charles. Putting popular music in its place. Cambridge: Cambridge University Press, 1995.

HAWKINS, Stan. Perspectives in Popular Musicology: Music, Lennox, and Meaning in 1990s Pop. Popular Music, v.15, n.1, 1996, p.17-36.

HEINICH, Nathalie. A sociologia da arte. Tradução de Maria Ângela Casellato e revisão técnica de Augusto Capella. Título original: La sociologie de l'art c2001. Bauru: UDUSC, 2008, p.35.

HOBSBAWM, Eric. J. História social do jazz. Rio de Janeiro: Paz e Terra, 1990. Título original: The jazz scene.

. A era dos extremos: o breve século XX (1914-1991). Tradução: Marcos Santarrita. São Paulo: Companhia das Letras, 1995.

HOBSBAWM, Eric; RANGER, T. A Invenção das tradições. Rio de Janeiro. Editora Paz e Terra, 1997.

HUNT, Lynn. A nova história cultural. Tradução de Jefferson Luiz Camargo e revisão de Silvana Vieira. Título original: The new cultural history. São Paulo, Martins Fontes, 1992. 
JAMBEIR0, Othon. Canção de massa: as condições da produção. São Paulo: Pioneira, 1975.

JOÃO DO RIO (pseudônimo de João Paulo Emílio Cristóvão dos Santos Coelho Barreto). A alma encantadora das ruas. Fundação Biblioteca Nacional. Disponível em $<$ www.dominiopublico.gov.br $>$

KERMAN, Joseph. A few canonic variations. Critical Inquiry. The University of Chicago Press, vol. 10, nำ1, pp. 107-125, 1983.

. Musicologia. Coleção Opus-86. São Paulo: Martins Fontes, 1987. Titulo original: Contemplating music: challenges to Musicology, 1985.

KUNST, Jaap. Ethnomusicology. Netherlands: The Hague Martinus Nijhoff, 1959.

LEAL, José de Souza. João Pernambuco: a arte de um povo. Rio de Janeiro: FUNARTE, 1982.

LENHARO, Alcir. Cantores do rádio: a trajetória de Nora Ney e Jorge Goulart e o meio artístico do seu tempo. Campinas: Editora da UNICAMP, 1995.

LIRA, Mariza. Chiquinha Gonzaga: grande compositora brasileira. 2ª ed. Rio de Janeiro: FUNARTE, 1978.

LIMA, Edilson de. As Modinhas do Brasil. São Paulo, EDUSP, 2001.

LIMA, Luiz Costa. Teoria da Cultura de Massa. 7a Ed. São Paulo: Paz e Terra, 2005. Primeira edição: Rio de Janeiro: Editora Saga, 1969.

LÓPEZ CANO, Rubén. El arte en la era de la reproducción mecánica de citas de Walter Benjamín. Observatorio de Prácticas Musicales Emergentes. Disponível em:

<observatorio-musica.blogspot.com/2010/01/el-arte-en-la-era-de-lareproduccion.html> Acesso em: 26 jul. 2010.

LÚCIO, Rangel. Sambistas \& chorões: aspectos e figuras da música popular brasileira. São Paulo: Francisco Alves, 1962.

MAGNOLI, Demétrio. Uma gota de sangue: história do pensamento racial. São Paulo: Contexto, 2010.

MARTÍN-BARBERO, Jesús. Dos meios às mediações: comunicação, cultura e hegemonia. Tradução de Ronald Polito e Sérgio Alcides. 4⿳a ed. Rio de Janeiro: Editora UFRJ, 2006. Primeira edição espanhola, 1987. Primeira edição brasileira, 1997.

MARTINS, José de Souza. Capitalismo e tradicionalismo: estudo sobre as contradições da sociedade agrária no Brasil. São Paulo: Pioneira, 1975.

MARX, Karl. O capital: crítica da economia política. Vol.1. São Paulo: Abril Cultural, 1984. 
MATOS, Claudia Neiva. Acertei no milhar: samba e malandragem no tempo de Getúlio. Rio de Janeiro: Paz e Terra, 1982.

MATOS, Maria Izilda Santos de; FARIA, Fernando. Melodia e sintonia em Lupicínio Rodrigues: o feminino, o masculino e suas relações. Rio de Janeiro: Bertrand Brasil, 1996.

McCANN, Bryan. Hello, hello Brazil: popular music in the making of modern Brazil. Durham, London: Duke University Press, 2004.

MEDAGLIA, Júlio. Música impopular. São Paulo: Global, 1988.

MEDINA, Carlos Alberto de. Música popular e comunicação. Petrópolis, Vozes, 1973.

MELLO, Zuza Homem de; SEVERIANO, Jairo. A canção no tempo: 85 anos de músicas brasileiras. São Paulo: Editora 34. vol.1 (1901-1957), 1997 e vol.2 (1958-1958), 1998.

MENDES, Gilberto. A música. In: ÁVILA, Affonso (org.). O modernismo. São Paulo: Perspectiva, 1975.

MENESES, Adélia Bezerra de. Desenho mágico: poesia e política em Chico Buarque. 2a ed.. São Paulo. Ateliê Editorial, 2000. 1a ed. São Paulo: Hucitec, 1982.

MERRIAM, Alan, P. The Anthropology of Music. Northwestern University Press, 1964.

Ethnomusicology revisited. Ethnomusicology, v.3, n.2, p.213-229, 1969.

Definitions of "Comparative Musicology" and "Ethnomusicology": An

Historical-Theoretical Perspective. Ethnomusicology, v.21, n.2, p.189-204, 1977.

MESSIAS, Thales de Oliveira. O expressionismo musical: uma análise estética. Monografia de TCC. Uberlândia: UFU, 2010.

MIDDLETON, Richard. Studying Popular Music. Great Britain: Open University Press, 1990.

MIS-RJ. Museu da Imagem e do Som do Rio de Janeiro. As vozes desassombradas do museu. Rio de Janeiro: Secretaria da Educação e Cultura/MIS-RJ, 1970.

MISSÃO DE PESQUISAS FOLCLÓRICAS - MÁRIO DE ANDRADE. Caixa contendo 6 CDs, livreto e 3 catálogos histórico-fonográficos. São Paulo: SESC, 2006.

MOBY, Alberto. Sinal Fechado: a música popular brasileira sob censura (1937-45 / 1969-78). $2^{\text {a }}$ ed. Rio de Janeiro, Apicuri, 2008. Primeira edição: Rio de Janeiro, Obra Aberta, 1994.

MORAES, José Geraldo Vinci de. Música popular: fontes e acervos. Teresa: revista de literatura brasileira. Publicação do Programa de Pós-Graduação da área de Literatura Brasileira da FFLCH / USP. São Paulo: Editora 34, no 4 e 5, 2003, p. 401-406. 
História e música: canção popular e conhecimento histórico. Revista Brasileira de História, no 39. São Paulo: ANPUH / Humanitas / FAPESP, 2000, p. 203-221.

. História e historiadores da música popular urbana no Brasil. Comunicação apresentada no VI Congresso da IASPM-AL. Buenos Aires, 2005. Disponível nos anais do evento em <www.hist.puc.cl/iaspm/iaspm.html>

Os primeiros historiadores da música popular urbana no Brasil. In: ArtCultura. Uberlândia: EDUFU, v.8 nํㅜ13, 2006, p.117-133.

. Sons e música na oficina da História. In: REVISTA DE HISTÓRIA. Departamento de História da FFLCH-USP. São Paulo: Humanitas/FFLCH-USP, no 157, $2^{\circ}$ semestre de 2007, pp. 7-13.

MORAES, José Geraldo Vinci de; SALIBA, Elias Thomé (orgs.). História e Música no Brasil. São Paulo: Alameda, 2010.

MORAES, Mario. Recordações de Ary Barroso. Rio de Janeiro: FUNARTE, 1979.

MORIN, Edgar. Não se conhece a canção. In: Linguagem da Cultura de Massas: televisão e canção. Coleção Novas Perspectivas em Comunicação no 6, Vozes, 1973.

. Cultura de Massas no Século XX: o espírito do tempo. Rio de Janeiro: Editora Forense Universitária, 1967.

MOURA, Roberto. Tia Ciata e a pequena África no Rio de Janeiro. Rio de Janeiro: FUNARTE, 1983.

NAPOLITANO, Marcos. História \& música: história cultural da música popular. Belo Horizonte, Autêntica, 2002.

. A bibliografia sobre música popular brasileira: um balanço inicial (1970-2000). Simpósio Latino-americano de Musicologia. Curitiba, 2000.

. 0 "conceito" de MPB nos anos 60. In: História: questões \& debates. Curitiba, PR: Editora da UFPR, ano 16, n. 31, pág. 13 a 30, 1999.

. A historiografia da música popular brasileira (1970-1990): síntese bibliográfica e desafios atuais da pesquisa histórica. In: ArtCultura. Uberlândia: EDUFU, v.8 noํㅜ 13, 2006, p.135-150.

A Síncope das idéias: a questão da tradição na música popular brasileira. São Paulo: Editora Fundação Perseu Abramo, 2007.

História e música popular: um mapa de leituras e questões. In: REVISTA DE HISTÓRIA. Departamento de História da FFLCH-USP. São Paulo: Humanitas/FFLCHUSP, no 157, 2o semestre de 2007, pp. 153-171. 
NAPOLITANO, Marcos; WASSERMAN, Maria Clara. Desde que o samba é samba: a questão das origens no debate historiográfico sobre a música popular brasileira. Revista Brasileira de História: São Paulo, v.20, nº 39, p.167-189, 2000.

NAVES, Santuza Cabraia et al. Levantamento e comentário crítico de estudos acadêmicos sobre música popular no Brasil. ANPOCS bib: Revista Brasileira de Informação Bibliográfica em Ciências Sociais no 51, São Paulo, 2001.

NEEDELI, Jeffrey D.. Belle Époque tropical: sociedade e cultura de elite no Rio de Janeiro na virada do século. São Paulo: Companhia das Letras, 1993. Titulo original A Tropical Belle Epoque: elite culture and society in turn-of-the-century Rio de Janeiro, $1^{\text {a }}$ ed. 1988.

NEGUS, Keith. Popular music in theory: an introduction. Hanover: Wesleyan University Press, 1996.

NESTICO, Sammy. The complete arranger. Fenwood Music Co., 1993.

NETTL, Bruno. The seminal eighties: a North American perspective of the beginnings of musicology and ethnomusicology. TRANS - Revista Transcultural de Música, no 1, 1995. Disponível em <www.sibetrans.com/trans/trans1/nettl.htm>. Acesso em: 10 jul. 2008.

NEVES, José Maria. Música Contemporânea Brasileira. São Paulo: Ricordi Brasiliera, 1981.

OROSCO, Maurício. [Mensagem eletrônica pessoal ao autor]. Recebida em: 17 out. 2010.

ORTIZ, Renato. A moderna tradição brasileira: cultura brasileira e indústria cultural. São Paulo: Editora Brasiliense, 1988.

. Cultura brasileira e identidade nacional. São Paulo: Brasiliense, 1994.

OXFORD MUSIC ONLINE. Oxford University Press. Site de acesso restrito mediante assinatura (individual ou institucional). Disponível em:

<www.oxfordmusiconline.com>. Diversos acessos entre: out. 2009 e out. 2010.

PARANHOS, Adalberto. Novas bossas e velhos argumentos: tradição e

contemporaneidade na MPB. História \& Perspectivas, nํ3, Departamento de História, UFU, 1990.

PEREIRA, João Baptista Borges. Côr, profissão e mobilidade: o negro e o rádio de São Paulo. São Paulo: Pioneira Editora / Editora da USP, 1967.

PERRONE, Charles. Letras e letras da música popular brasileira. Rio de Janeiro: Elo Editora, 1988.

PINTO, Alexandre Gonçalves (Animal). O choro: reminiscências dos chorões antigos. Fac-símile da edição de 1936. Rio de Janeiro: FUNARTE, 1978. 
PINTO. Tiago de Oliveira. Cem anos de Etnomusicologia e a "era fonográfica" da disciplina no Brasil. In: Anais do II Encontro Nacional da ABET. Salvador, 2004.

POPPER, Karl. Lógica das Ciências Sociais. 2ª ed.. Rio de Janeiro: Tempo Brasileiro, 1999.

POUND, Ezra. $A B C$ da Literatura. 11a ed. São Paulo: Cultrix, 2006, pp. 9-14.

PUTERMAN, Paulo. Indústria cultural: a agonia de um conceito. São Paulo: Perspectiva, 1994.

RANGEL, Lúcio. Sambistas e chorões: aspectos e figuras da música popular brasileira. São Paulo: Francisco Alves, 1962.

RANDEL, Don Michael. The Canons in the Musicological Toolbox. In: In: BERGERON, Katherine; BOHLMAN, Philip. (eds.) Disciplining Music: musicology and its canons. The University of Chicago Press, 1992, p.116-136.

REVISTA DA MÚSICA POPULAR. Coleção completa em fac-símile. Rio de Janeiro: Bemte-vi Produções Literárias / FUNARTE, 2006.

REVISTA CIVILIZAÇÃO BRASILEIRA. Ano I, nำ 7, maio de 1966. Que caminho seguir na música popular brasileira?

REVISTA DE HISTÓRIA. Departamento de História da FFLCH-USP. São Paulo: Humanitas/FFLCH-USP, nํㅜ 157, 2º semestre de 2007.

RHODES, Willard. A short history of the founding of SEM, 1980. Disponível em: <http://webdb.iu.edu/sem/scripts/aboutus/aboutsem/sem_history_founding.cfm>. Acesso em: 15 set. 2009.

RICARDO, Sérgio. Quem quebrou meu violão: uma análise da cultura brasileira nas décadas de 40 a 90. Rio de Janeiro: Record, 1991.

RICE, Timothy. Toward the Remodeling of Ethnomusicology. Ethnomusicology, v.31, n.3, p.469-488, 1987.

ROMERO, Silvio. Cantos Populares do Brasil. 2v. Livraria José Olympio Editora, 1954.

ROSEN, Charles. Formas de sonata. Cooper city: Span press, 1998.

The classical style: Haydn, Mozart e Beethoven. Nova York: W.W. Norton, 1997 A geração româtica. São Paulo: EDUSP, 2000.

RUSSELL, George. The lydian chromatic concept of tonal organization. Nova York: Concept Publishing Co. Primeira edição de 1953, publicação do autor. 
SALIBA, Elias Thomé. Mentalidades ou história sociocultural: a busca de um eixo teórico para o conhecimento histórico. In: Margem / PUC-SP no1. São Paulo: EDUC, 1992, pp.29-36.

SANDRONI, Carlos. Feitiço decente: transformações no samba no Rio de Janeiro (19171933). Rio de Janeiro: Zahar / UFRJ, 2001.

SANT'ANNA, Affonso Romano de. Música popular e moderna poesia brasileira. 4⿳亠丷a ed. São Paulo: Editora Landmark, 2004. Primeira edição. Petrópolis: Vozes, 1977.

SCHORSKE, Carl E. Fin-de-siècle Vienna: politics and culture. Crawfordsville, Indiana, USA: R.R. Donnelley \& Sons Company, 1981.

SCHWARZ, Roberto. O pai de família e outros estudos. Rio de Janeiro: Paz e Terra, 1978.

SEEGER, Charles. Semantic, Logical and Political Considerations Bearing upon Research in Ethnomusicology. Ethnomusicology, vol. 5, nํ2, 1961, pp. 77-80.

SHUKER, Roy. Vocabulário de música pop. Tradução: Carlos Szlak. São Paulo: Hedra, 1999. Titulo original: Key concepts in popular music, 1998.

SILVA, Marília T. Barboza da. Cartola: os tempos idos. $2^{\underline{a}}$ ed. Rio de Janeiro: FUNARTE, 1989. 1989.

Paulo da Portela: traço de união entre duas culturas. Rio de Janeiro: FUNARTE,

Silas de Oliveira: do jongo ao samba-enredo. Rio de Janeiro: FUNARTE, 1981.

SILVA, Marília T. Barbosa da; OLIVEIRA FILHO, Arthur L. de. Pixinguinha: filho de Ogum bexiguento. Rio de Janeiro, FUNARTE, 1979.

SQUEFF, Ênio; WISNIK, José Miguel. Música: o nacional e o popular na cultura brasileira. São Paulo: Brasiliense, 1982.

SODRÉ, Muniz. Samba: o dono do corpo. 2ª ed.. Rio de Janeiro: Mauad, 1998. Primeira edição. Rio de janeiro: Codecri, 1979.

STOREY, John. Inventing Popular Culture. Malden, USA: Blackwell Publishing, 2003.

Cultural theory and popular culture: an introduction. 5th ed. Harlow, Essex, England: Pearson Educational, 2009

STROUD, Sean. The defense of tradition in Brazilian popular music: politics, culture and the creation of Música Popular Brasileira. Hampshire: Ashgate Publishing Group, 2007.

TAGG, Philip. Analysing popular music. Popular Music nº 2, p.37-67, 1982. Disponível em: <www.tagg.org>. Acesso em: jul. 2007. 
. Why IASPM? Which tasks? Comunicação à $2^{\text {a }}$ Conferencia Internacional da IASPM, 1983. Popular Music Perspectives 2, p.501-507, D. Horn (ed.), IASPM, Göteborg and Exeter, 1985. Disponível em: <www.tagg.org>. Acesso em: jul. 2007.

TAGG, Philip; CLARIDA, Bob. Ten little title tunes: Towards a musicology of the mass media. New York \& Montreal: The Mass Media Music Scholars' Press, 2003.

TATIT, Luiz. O cancionista: composição de canções no Brasil. São Paulo: Edusp, 1995. . O século da canção. Cotia: Ateliê Editorial, 2004. Todos entoam: ensaios, conversas e canções. São Paulo: Publifolha, 2007.

TERESA: revista de literatura brasileira. São Paulo: Editora 34, no 4 e 5, 2003. Publicação do Programa de Pós-Graduação da área de Literatura Brasileira do Departamento de Letras Clássicas e Vernáculas da FFLCH / USP.

TINHORÃO, José Ramos. Música popular: um tema em debate. 3aㅡ ed. São Paulo: Editora 34, 1997. Primeira edição: Rio de Janeiro: Editora Saga, 1966.

. O samba agora vai: a farsa da música popular no exterior. Rio de Janeiro: JCM Editores, 1969.

Música popular: de índio, negros e mestiços. Petrópolis: Vozes, 1972.

Pequena história da música popular brasileira. São Paulo: Art Editora, 1991. Primeira edição: Petrópolis: Vozes, 1974.

. Música popular: os sons que vem da rua. 2 ed.. São Paulo: Editora 34, 2005. Primeira edição, 1976.

. Os sons dos negros no Brasil: cantos, danças, folguedos, origens. São Paulo: Art Editora, 1988.

. História social da música popular brasileira. São Paulo: Editora 34, 1998. Primeira edição portuguesa: Lisboa, Editorial Caminho, 1990.

. Cultura popular: temas e questões. São Paulo: Editora 34, 2001.

TOMÁS, Lia Vera. Uma reflexão sobre a estética musical e a filosofia da música. Uberlândia: Revista ouvirOUver, vol. 1, no 5, 2009.

TRAVASSOS, Elizabeth. Modernismo e música brasileira. Rio de Janeiro: Zahar, 2000.

TREECE, David. Melodia, texto e $O$ cancionista, de Luiz Tatit. In: TERESA: revista de literatura brasileira. São Paulo: Editora 34, no 4 e 5, 2003, pp.332-350.

VAINFAS, Ronaldo. História cultural e história das mentalidades. In: CARDOSO; VAINFAS (orgs.). Domínios da História. Rio de Janeiro: Campus, 1997. 
VASCONCELOS, Ary. Panorama da música popular brasileira. São Paulo: Martins, 1964. . Panorama da música popular brasileira na Belle Époque. Rio de Janeiro: Livraria Sant'Anna, 1977. 1977. Raízes da música popular brasileira (1500-1889). São Paulo: Livraria Martins,

VASCONCELLOS, Gilberto. Música popular: de olho na fresta. Rio de Janeiro, Graal, 1977.

VELOSO, Caetano. Primeira feira de balanço. In: SALOMÃo, Waly (org.). Alegria, alegria: uma caetanave. Rio de Janeiro: Pedra \& Ronca, 1977. Texto publicado originalmente na Revista Ângulos, da Faculdade de Direito da UFBA, 1966.

VELLOSO. Monica Pimenta. As tradições populares na Belle Époque carioca. Rio de Janeiro: FUNARTE, 1988.

VIANNA, Hermano. O mistério do samba. Rio de Janeiro: Zahar, 1995.

VILARINO, Ramon Casas. A MPB em movimento: música, festivais e censura. 5aㅡ ed. São Paulo: Olho d’Água, 2006. Primeira edição em 1999.

WEBER, Max. Fundamentos racionais e sociológicos da música. São Paulo: EDUSP, 1995.

WEBER, William. The eighteenth-century origins of the musical canon. Journal of the Royal Musical Association, vol. 114, nํㅜ 1, pp. 6-17, 1989.

WILLIAMS, Raymond. Marxismo e literatura. Rio de Janeiro: Zahar, 1979.

. Cultura. São Paulo: Paz e Terra, 1992.

Palavras-chave: um vocabulário de cultura e sociedade: São Paulo: Boitempo, 2007.

WISNIK, José Miguel. Getúlio da paixão cearense (Villa-Lobos e o Estado Novo). In: SQUEFF; WISNIK. Música: o nacional e o popular na cultura brasileira. São Paulo: Brasiliense, 1982.

O coro dos contrários: música em torno da semana de 22. 2ª ed. São Paulo: Duas Cidades, 1983. $1^{\text {a }}$ edição, 1977.

Machado maxixe: o caso Pestana. In: TERESA: revista de literatura brasileira. São Paulo: Editora 34, no 4 e 5, 2003.

Sem receita: ensaios e canções. São Paulo: Publifolha, 2004.

ZAMPRONHA, Edson. Notação, representação e composição: um novo paradigma da escritura musical. São Paulo: Annablume/FAPESP, 2000. 
Anexo 


\begin{tabular}{|l|l|l|l|}
\hline \hline \multicolumn{1}{|c|}{ Samba da Legitimidade } & GRAU: & Mestrado \\
\hline AUTOR: & Antonio Pedro Tota & ANO: & 1980 \\
\hline ORIENTADOR: & Sônia Apparecida de Siqueira & Área: & História \\
\hline UNIVERSIDADE: & FFLCH / USP & &
\end{tabular}

Excertos:

Dissertação de mestrado que tem por fim demonstrar que o Estado Autoritário instituído pelo golpe de 1937 por Getúlio Vargas, se utilizou da canção popular, mais precisamente de alguns gêneros dela, para veicular a Ideologia do Trabalhismo, necessária para que se processasse sua legitimação." (p. 8)

Para o processo de cooptação não havia necessidade de mediação direta ente os organismos do novo Estado e os compositores que produziam canções carregadas da Ideologia do Trabalhismo. Esta Ideologia impregnava quase todas as manifestações da área cultural, em especial a produção da canção popular. Um levantamento das canções produzidas na época nos revelou que aproximadamente $60 \%$ delas possuíam, de uma forma ou de outra, um chamamento ideológico apontando na direção da Ideologia do Trabalhismo.

Cooptação indireta. Não havia ligação direta entre o Departamento de Imprensa e Propaganda e o compositor, incentivando a produção de canções que veiculassem a Ideologia do Trabalhismo. Nem muito menos chegava-se a proibir a produção de canções que veiculassem o sentido antitético da Ideologia do Trabalhismo, ou seja, a malandragem/vagabundagem.

Enfim, o "trabalhismo" estava colado ao texto da produção da canção popular. Apesar da afirmação de Adorno de que nem sempre é possível encontrar nexos mais claros entre o social e o estético, aqui havia essa tendência. (p.147)

\begin{tabular}{|l|l|l|l|}
\hline \hline \multicolumn{1}{|c|}{2} & Luiz Gonzaga - o migrante nordestino na música popular brasileira \\
\hline AUTOR: & Antonio Gomes da Silva & GRAU: & Doutorado \\
\hline ORIENTADOR: & Dispensado de orientador, art. n 103 da USP & ANO: & 1986 \\
\hline UNIVERSIDADE: & FFLCH / USP & ÁREA: & História \\
\hline
\end{tabular}

Excertos:

Podendo tranqüilamente ser considerado, ao lado de Pixinguinha (\& do choro), de Noel Rosa (\& do samba urbano), de Dorival Caymmi ( $\&$ da música do mar e da Bahia), como um dos que mais contribuíram para a efetiva consolidação e caracterização de uma das manifestações mais marcantes e vivazes da história da nossa produção cultural, isto é, a inconfundível Música Popular Brasileira, Luiz Gonzaga (\& o xote e o maracatu e 0 baião...), bem como sua vida e sua obra nos convidam, a nós ouvintes, pesquisadores e leitores, sabe para que? Eles todos nos convidam, exato, para uma viagem, mergulho, vôo, caminhada em busca da concretização de um estudo sociológico a fim de sabermos, de descobrirmos, juntos, o que aconteceu de fato à vida-obra gonzaguiana no "eixo" Exú-Brasil-Paris-Exu, Brasil. (p.12)

\begin{tabular}{|l|l|l|l|}
\hline \hline \multicolumn{1}{|c|}{3} & Brasil Novo: música, nação e modernidade. Os anos 20 e 30. \\
\hline AUTOR: & Arnaldo Daraya Contier & GRAU: & Livre docência \\
\hline ORIENTADOR: & & ANO: & 1988 \\
\hline UNIVERSIDADE: & FFCLH / USP & ÁREA: & História \\
\hline \multicolumn{4}{|l}{} \\
\end{tabular}




\begin{tabular}{|l|l|l|l|}
\hline \hline \multicolumn{1}{|c|}{4} & \multicolumn{4}{l|}{$\begin{array}{l}\text { As sonoridades paulistanas: a música popular na cidade de São Paulo no final do séc XIX ao } \\
\text { início do XX }\end{array}$} & GRAU: & Mestrado \\
\hline AUTOR: & José Geraldo Vinci de Moraes & ANO: & 1989 \\
\hline ORIENTADOR: & Elias Thomé Saliba & ÁREA: & História \\
\hline UNIVERSIDADE: & PUC / SP &
\end{tabular}

Resumo:

Este trabalho é uma tentativa inicial de procurar desvendar o processo de construção e constituição da música popular urbana na cidade de São Paulo, entre o término do século XIX até o final da década de 20. A periodização segue estes contornos gerais, pois, é no início deste período que a cidade começava o processo de instituição da estrutura urbana-moderna e seus modos de representação social e cultural, acentuado na passagem do século. Os últimos anos da década de 1920 servem como balizamento final na medida em que as relações entre a produção e a reprodução musical ainda não haviam sido profundamente alterados pela indústria fonográfica e radiofônica, que davam seus passos preliminares.

No espaço urbano marcado por um cosmopolitismo repleto de contradições fragmentado entre o universo rural e o mundo urbano, despontariam tensões sociais e culturais elaboradas pelas experiências de negros, diversos imigrantes e caipiras, a maioria sobrevivendo como sub-empregados, desempregados, ambulantes, pequenos artesãos, operários, etc. Toda essa trama social proporcionou conflitos/encontros sócio-culturais muito peculiares, que acabaram dando o tom da trilha sonora do cotidiano paulistano, que procuramos compreender através deste trabalho investigativo.

Sonoridades paulistanas: final do século XIX ao início do século XX: Rio de Janeiro: FUNARTE, 1995.

\begin{tabular}{|c|c|c|c|}
\hline 5 & \multicolumn{3}{|c|}{$\begin{array}{l}\text { Uma estratégia de controle: A relação do poder do estado com as Escolas de Samba do Rio } \\
\text { de Janeiro no período de } 1930 \text { a } 1985\end{array}$} \\
\hline AUTOR: & José Luiz de Oliveira & GRAU: & Mestrado \\
\hline ORIENTADOR: & Francisco José Calazans Falcon & ANO: & 1989 \\
\hline UNIVERSIDADE: & UFRJ & ÁREA: & História \\
\hline
\end{tabular}

Resumo:

Este trabalho é um estudo das relações entre Estado e Cultura Popular na cidade do Rio de Janeiro durante um período delimitado pela institucionalização das Escolas de Samba e o ano de 1985. Nosso objeto de pesquisa é constituído pelas várias formas assumidas pela intervenção direta ou indireta do Estado sobre um tipo de manifestação popular particularmente importante no âmbito da sociedade carioca. Não se trata de mais uma história das Escolas de Samba do Rio de Janeiro e sim de uma investigação interdisciplinar na qual foram utilizados dentre outros, os métodos dos da história oral. As relações entre o poder estatal no seu sentido mais amplo e as Escolas de Samba traduzem as pressões exercidas pelo Estado e as resistências dos setores populares num perfil que reflete, também, as mudanças políticas e ideológicas ocorridas na sociedade brasileira ao longo do período pesquisado. 


\begin{tabular}{|l|l|l|l|}
\hline \hline \multicolumn{1}{|c|}{6} & \multicolumn{3}{|l|}{$\begin{array}{l}\text { Trilha sonora: topografia semiótica paulistana nas canções independentes das décadas de } \\
\text { setenta e oitenta }\end{array}$} \\
\hline AUTOR: & Fátima Amaral Dias de Oliveira & GRAU: & Mestrado \\
\hline ORIENTADOR: & Alcir LenharO & ANO: & 1989 \\
\hline UNIVERSIDADE: & UNICAMP / IFCH & ÁREA: & História \\
\hline
\end{tabular}

Para escrever sobre percepções do cotidiano na cidade de São Paulo escolhi uma aproximação musical. A música parece ser a forma de expressão cultural mais fértil no Brasil. [...]

Dizem que depois do cinema falado nossa vida ganhou definitivamente uma trilha sonora, mas também o rádio envolve nosso cotidiano em canções, dá ritmo e um certo colorido aos nossos movimentos. Por outro lado, nossas relações com a cidade, o trânsito, as máquinas, a TV também modulam nossas vibrações corporais e podem ressoar musicalmente.[...]

[...] A superposição afetiva da música e da cidade apontou o caminho para uma percepção diferente dessa metrópole, onde é possivel entender, de certa forma como atua esse imã-cidade, esse sentimento de estranheza, essa paixão pelo outro. Se para cada um o magnetismo é diferente, então cabe historiar a experiência de muitos - inventário de diferenças.

Ao fazer uma história das percepções, lidando com música, forçosamente é preciso pensá-la como forma de expressão que não faz parte apenas do cógito racional, domínio do significante. As músicas são ressonâncias de sensações-vibrações, ruídos, cores, luminosidades, que não passam necessariamente pelo código da palavra.[...] [...] Nesse sentido, passo a explicar, a seguir, como os ritmos ressoam nas canções experiências profundas das vivências urbanas e rurais de nossa sociedade. Ao semiotizar experiências inconscientes, tornando-as música, diversos artistas trazem para nossa vida diferentes possibilidades de percepção, criando assim novas maneiras virtuais de viver a cidade, adensamento de experiências deslocadas/despedaçadas de migrantes. Remontam e dissolvem a cidade, não o território único urbano, absorvem e mixam miragens, para criar trilhas sonoras que tornam o viver aqui potencialmente diferente. (p.3-10)

\begin{tabular}{|l|l|l|l|}
\hline \hline \multicolumn{1}{|c|}{7} & Capoeiras e malandros: pedaços de uma sonora tradição popular (1890-1950) \\
\hline AUTOR: & Maria Angela Borges Salvadori & GRAU: & Mestrado \\
\hline ORIENTADOR: & Maria Clementina Pereira Cunha & ANO: & 1990 \\
\hline UNIVERSIDADE: & UNICAMP / IFCH & ÁREA: & História \\
\hline
\end{tabular}

Resumo:

Esta pesquisa procura recuperar as experiências urbanas de capoeiras e malandros na cidade do Rio de Janeiro, após a extinção oficial do regime de trabalho escravo. Estampados entre 1890 e 1950 como sinônimos da violência urbana, eles mantiveram uma tradição de luta pela liberdade aprendida desde os tempos da escravidão, procurando preservar uma margem de autonomia e deliberação sobre suas próprias vidas. Envolvidos por um contexto de valorização moral do trabalho e de exaltação da figura do trabalhador, foram rotulados como sinônimos de vadiagem e violência urbana.

Ao longo do texto, pretendi, exatamente, mostrar que aquilo que as falas disciplinares da polícia, da grande imprensa e de intelectuais ligados ao Estado ou a suas propostas percebiam como desordem e ameaça social era, quando analisado por um ângulo mais interno, uma prática de vida onde a liberdade pretendia ser preservada.

É claro que não coloco capoeiras e malandros como personagens iguais, mas procuro salientar que entre eles é possivel alinhavar uma tradição.

Assim, reaparecem aqui várias questões trabalhadas na historiografia brasileira mais recente, tais como as visões de liberdade alicerçadas pelos negros, os projetos disciplinares de controle da população pobre da cidade e a resistência oferecida pelos grupos populares a estes mecanismos.

A música popular brasileira é, por assim dizer, o eixo documental deste trabalho, que se utiliza, ainda, de fontes literárias, jornalísticas, policiais, biográficas e de memória. 


\begin{tabular}{|c|c|c|c|}
\hline 8 & \multicolumn{3}{|c|}{$\begin{array}{l}\text { No fim da estrada: a trajetória artística de Nora Ney e Jorge Goulart no tempo dos cantores do } \\
\text { rádio }\end{array}$} \\
\hline AUTOR: & Alcir Lenharo & GraU: & Livre decência \\
\hline ORIENTADOR: & & ANO: & 1992 \\
\hline UNIVERSIDADE: & IFCH / UNICAMP & ÁREA: & História \\
\hline
\end{tabular}

\begin{tabular}{|l|l|l|l|}
\hline \hline \multicolumn{1}{|c|}{9} & O sertão nos embalos da música rural 1929-1950 \\
\hline AUTOR: & Wolney Honório Filho & GRAU: & Mestrado \\
\hline ORIENTADOR: & Dea Ribeiro Fenelon & ANO: & 1992 \\
\hline UNIVERSIDADE: & PUC/SP & ÁREA: & História \\
\hline
\end{tabular}

Resumo:

A música sertaneja no Brasil aparece, enquanto um gênero musical, passando a ocupar inclusive destaque junto às gravadoras da época, em 1929. Cornélio Pires, pesquisador e, ao mesmo tempo, animador e divulgador da cultura do homem rural paulista, vai financiar a edição de vinte e cinco mil cópias de discos caipiras na gravadora Colúmbia. Este fato se apresenta enquanto um marco na história da música rural.

Esta pesquisa porém, não segue as trilhas da história da música. Mas, se inspira nela, tentando perceber as significações rurais que estavam em jogo quando da inauguração dos discos caipiras, assim como, que imagens rurais habitavam o seu interior ao reinar a técnica industrial de conservação do som sertanejo.

Assim, há três recortes essenciais. Um primeiro, passando pelas descrições do tipo humano, habitante do sertão. Outro, tentando perceber como a técnica de conservação do som se relaciona com as noções de tempo e comunicação rurais. E, por fim, as visões do sertão que perpassam no momento de substituição do enfoque dado do peão boiadeiro para o caminhoneiro.

\begin{tabular}{|l|l|l|l|}
\hline \hline \multicolumn{1}{|c|}{10} & Sinal fechado: a música popular brasileira sob censura (1937-45 / 1969-78) \\
\hline AUTOR: & Alberto Moby & GRAU: & Mestrado \\
\hline ORIENTADOR: & Ismênia de Lima Martins & ANO: & 1993 \\
\hline UNIVERSIDADE: & UFF & ÁREA: & História \\
\hline
\end{tabular}

O trabalho se propõe a fazer uma análise comparada do papel da censura no Estado Novo e no regime militar, procurando identificar qual foi a política destes regimes autoritários para a cultura em geral e a música em particular, quais seus objetivos e quais foram as posições dos compositores frente ao regime e à censura. 0 autor procura demonstrar que Estado Novo e regime militar, embora tivessem visões semelhantes de estadonação baseadas em pressupostos autoritários e antiliberais, cada um, ao menos no que diz respeito às artes em geral, e à música popular, em particular, teve propostas e práticas bastante distintas. Assim, para 0 autor, querer aproximá-las para além de uma generalização enquanto autoritarismos, seria atropelar as especificidades históricas de cada um dos dois regimes, uma vez que se tratam de dois autoritarismos distintos para os quais não se poderia utilizar os mesmos parâmetros, baseados numa conceituação meramente abstrata de "autoritarismo" ou de "ditadura".

Sinal fechado: a música popular brasileira sob censura (1937-45 / 1969-78). Rio de Janeiro, Obra Aberta, 1994. 


\begin{tabular}{|l|l|l|l|}
\hline \hline \multicolumn{1}{|c|}{11} & Dimensões da vida urbana sob o olhar de Chico Buarque & \multicolumn{3}{c|}{} \\
\hline AUTOR: & Míriam Porto Noronha & GRAU: & Mestrado \\
\hline ORIENTADOR: & Yara Maria Aun Khoury & ANO: & 1994 \\
\hline UNIVERSIDADE: & PUC & ÁREA: & História \\
\hline
\end{tabular}

Resumo:

A pesquisa "Dimensões da vida urbana sob o olhar de Chico Buarque" tem como objetivo, explorar dimensões das experiências sociais e seus significados. Utilizei como objeto de estudo a obra artística de Chico Buarque, especialmente a música, posto que nela encontramos construções de dimensões da realidade.

Partindo do pressuposto que o compositor tira da realidade sua própria arte e, inevitavelmente, sua própria maneira de ver aquela realidade, a pesquisa foi estruturada numa dimensão de Cultura.

Utilizando músicas como objeto central para análise, procurei mostrar a possibilidade de utilizá-las como um rico e importante documento histórico para releitura de dimensões da realidade social.

Outros documentos foram analisados afim de enriquecer o trabalho, tais como escritos sobre o compositor, entrevistas por ele concedidas, etc.

O período escolhido para estudo compreendeu as décadas de 60, 70 e 80 .

A partir do estudo do conjunto das música de Chico Buarque, busquei recuperar dimensões de problemáticas vividas, críticas, emoções, sentimentos, desejos, aspirações cantados e compartilhados pelo que poderíamos chamar de "geração dos anos 1960-70" da qual o compositor e cantor também faz parte.

Num esforço de viabilizar a organização do trabalho, foram elaborados três capitulos, onde procurei: recuperar os cenários em que as personagens criadas por Chico vivenciaram suas experiências, quais as personagens marcantes em sua obra musical, qual o significado do feminino em suas canções e as possíveis razões da forte identificação do público com a música de Chico Buarque.

\begin{tabular}{|l|l|l|l|}
\hline \hline \multicolumn{1}{|c|}{12} & Tropicália ou Panis et Circencis no país do Rei da Vela \\
\hline AUTOR: & Carmela Roseli Palmieri Parente Fialho & GrAU: & Mestrado \\
\hline ORIENTADOR: & Francisco Luiz Teixeira Vinhosa & ANO: & 1994 \\
\hline UNIVERSIDADE: & UFRJ & ÁREA: & História \\
\hline
\end{tabular}

Resumo:

O Tropicalismo caracterizou-se por ser um movimento artístico brasileiro inserido no âmbito da juventude contestadora da década de 1960. A produção cultural pós- golpe de 1964 se encaminhou para um repensar do papel do artista na sociedade brasileira. Nesse contexto, as obras conceituais como o filme Terra em Transe de Glauber Rocha, a peça O Rei da Vela de Oswald de Andrade, encenada pelo grupo Oficina, a obra-ambiental Tropicália de Hélio Oiticica, o disco-manifesto Tropicália ou Panis ct Circencis e os discos de Caetano Veloso e Gilberto Gil, traçaram um perfil de vanguarda dos tropicalistas durante os anos de 1967 e 1968 . O que unia esses diversos setores artísticos era a utopia da construção de uma cultura brasileira capaz de superar 0 subdesenvolvimento e a imagem de Brasil antropofágico resumia esse desejo de assumir e afirmar a brasilidade. 


\begin{tabular}{|c|c|c|c|}
\hline 13 & \multicolumn{3}{|c|}{$\begin{array}{l}\text { Custódio Mesquita, um compositor romântico: o entretenimento, a canção sentimental e a } \\
\text { política no tempo de Vargas (1930-1945) }\end{array}$} \\
\hline AUTOR: & Orlando de Barros & GRAU: & Doutorado \\
\hline ORIENTADOR: & Arnaldo Daraya Contier & ANO: & 1995 \\
\hline UNIVERSIDADE: & USP / FFLCH & ÁREA: & História \\
\hline \multicolumn{4}{|c|}{$\begin{array}{l}\text { Excerto: } \\
\text { É nossa intenção fazer nessa tese um estudo de diversos aspectos da cultura de massa, durante a vigência do } \\
\text { primeiro governo de Getúlio Vargas, abordando o estabelecimento do entretenimento público, e enfatizando } \\
\text { particularmente a canção popular urbana brasileira. Tomaremos como personagem central Custódio Mesquita } \\
\text { compositor popular e artista atuante em múltiplas atividades, que nos parece muito significativo como ilustração } \\
\text { do que pretendemos, seja por sua importância, seja pela sua interação com os acontecimentos da época } \\
\text { Personagem icônico em seu tempo, suscitou-nos curiosidade fascinante, a começar pela inteira coincidência } \\
\text { cronológica de sua carreira artística com o período Vargas. (p.1) }\end{array}$} \\
\hline
\end{tabular}

\begin{tabular}{|c|c|c|c|}
\hline 14 & \multicolumn{3}{|c|}{$\begin{array}{l}\text { Quando canta o Brasil: a Rádio Nacional e a construção de uma identidade popular } \\
\text { (1936-1945) }\end{array}$} \\
\hline AUTOR: & Cláudia Maria Silva de Oliveira & GraU: & Mestrado \\
\hline ORIENTADOR: & Ricardo Benzaquen de Araújo & ANO: & 1996 \\
\hline UNIVERSIDADE: & PUC/RJ & ÁREA: & História \\
\hline \multicolumn{4}{|c|}{$\begin{array}{l}\text { Resumo: } \\
\text { Este trabalho tem como tema os profissionais do rádio e as criações artísticas da Rádio Nacional entre } 1936 \text { e } \\
1945 . \\
\text { Procurei pesquisar a construção de uma linguagem radiofônica variada e eclética, neste período, a partir das } \\
\text { criações individuais dos artistas da Rádio Nacional e suas performances improvisacionais. } \\
\text { Comparei a linguagem inovadora da Rádio Nacional à linguagem conservadora da radiodifusão oficial. }\end{array}$} \\
\hline
\end{tabular}

\begin{tabular}{|l|l|l|l|}
\hline \hline \multicolumn{1}{|c|}{15} & A Jovem Guarda e os anos 60: uma festa de arromba & \multicolumn{3}{l|}{} \\
\hline AUTOR: & Elizete Mello da Silva & GRAU: & Mestrado \\
\hline ORIENTADOR: & Zélia Lopes da Silva & ANO: & 1996 \\
\hline UNIVERSIDADE: & UNESP / FCL - ASSIS & ÁREA: & História \\
\hline
\end{tabular}

Resumo:

O movimento Jovem Guarda surge na esteira da explosão do rock'n'roll internacional, no início da década de 60 . Nesta época a indústria cultural se expandia plenamente no país, possibilitando o aparecimento de um movimento ligado à juventude.

Em termos de produção musical, as leituras e interpretações das canções da Jovem Guarda tornam-se relevantes para detectar-se alguns signos importantes na compreensão do momento histórico, ao mesmo tempo esse tipo de análise se mostra fundamental para entendermos as contribuições fornecidas pelo movimento no âmbito cultural brasileiro. 


\begin{tabular}{|l|l|l|l|}
\hline \hline \multicolumn{1}{|c|}{16} & Nas tramas da fama: as estrelas do rádio em sua época áurea, Brasil, anos 40 e \\
\hline AUTOR: & Maria Marta Picarelli Avancini & GRAU: & \\
\hline ORIENTADOR: & Alcir Lenharo & ANO: & \\
\hline UNIVERSIDADE: & UNICAMP / IFCH & ÁREA: & História \\
\hline
\end{tabular}

A dissertação acompanha o surgimento das chamadas estrelas do rádio no Brasil, a partir do final da década de 40. Trata-se de um processo em ouvir as cantoras e os artistas ligados ao rádio são elevados à condição de estrelas por meio de mecanismos característicos de cultura e da comunicação de massa. 0 processo marca, então, a consolidação e a intensificação dos procedimentos e modos de funcionamento da comunicação de massa no Brasil. A pesquisa está baseada no cruzamento de três tipos de documentação - matérias publicadas em revistas da época (Revista do rádio e 0 Cruzeiro, gravações de programas de auditório da época e músicas integrantes dos repertórios das cantoras. 0 trabalho procura demonstrar como, por meio de mecanismos de exposição dos artistas e, em especial, cantoras criam-se determinadas figuras cujos perfis combinam elementos ligados à vida privada delas, às musicas que cantam e a fatos que acontecem com elas. Dentro do campo desses elementos neste processo, em que se cruzam séries discursivas e sígnicas diversas, criam-se territórios que definem modos de ser, comportamento, sociabilidade que demarcam a chamada cultura do rádio nos anos $40 \mathrm{e}$ 50. Neste mesmo processo, delineia-se uma estética historicamente demarcada.

\begin{tabular}{|l|l|l|l|}
\hline \hline \multicolumn{1}{|c|}{17} & \multicolumn{3}{l|}{ Chiquinha Gonzaga no Rio de Janeiro da "Belle Époque": um ensaio da memória } \\
\hline AUTOR: & Cleusa de Souza Millan & GRAU: & Mestrado \\
\hline ORIENTADOR: & Lena Vania Ribeiro Pinheiro; Icléia Thiesen Magalhães Costa & ANO: & 1996 \\
\hline UNIVERSIDADE: & UNIRIO & ÁREA: & História \\
\hline
\end{tabular}

Resumo:

Chiquinha Gonzaga foi uma personagem marcante em dois séculos de história de nosso país. Nesse ensaio de memória, para situá-la adequadamente na memória coletiva de nosso povo, traçou-se a sua trajetória, desde 0 Segundo Reinado até as três primeiras décadas da República, com ênfase no Rio de Janeiro da belle époque.

Essa personalidade construiu, com talento, uma obra musical vastíssima e significativa, ocupando na história da música popular de nosso país um lugar de destaque, por representar a sua fase de transição, em que se iniciou a fixação de uma temática brasileira na nossa música em meio ao predomínio de uma cultura europeizante.

Apesar da ressonância de sua obra nos meios de comunicação de cultura de massa, a sua memória social situase, atualmente, num aparente dualismo: memória-conhecimento, da elite cultural, e memória-desconhecimento, do povo. Este desconhecimento, que leva ao esquecimento de sua memória, tem causas que são equacionadas e analisadas para permitir a sugestão de soluções para situar adequadamente sua memória na memória coletiva do povo brasileiro.

\begin{tabular}{|l|l|l|l|}
\hline \hline \multicolumn{1}{|c|}{18} & Tangos brasileiros, Rio de Janeiro: 1870 /1920 \\
\hline AUTOR: & Paulo Roberto Peloso Augusto & GRAU: & Doutorado \\
\hline ORIENTADOR: & Arnaldo Daraya Contier & ANO: & 1996 \\
\hline UNIVERSIDADE: & USP / FFLCH & ÁREA: & História \\
\hline
\end{tabular}

Investiga a simbiose maxixe e tango brasileiro como uma estratégia em que o músico popular poderia veicular a dança popular de maior impacto, o maxixe - ao mesmo tempo taxado pela elite como dança excomungada - com um rótulo de garantida aceitabilidade: o tango. Traça o perfil das marcas ideológicas que dominaram a cidade do Rio de Janeiro na virada do século e estabelece uma discussão dos gêneros musicais populares através da análise musical, através das partituras. Constata a grande variedade de possibilidades formais para 0 tango. Acrescenta a possibilidade de combinação com outros gêneros, a influência da (e na) música erudita e sobretudo o papel de disfarce para o maxixe, burlando a ordem dominante estabelecida. Estuda a memória sonora que chegou até os dias atuais e investiga o músico popular em suas motivações, falas, atuações e contradições. 


\begin{tabular}{|l|l|l|l|}
\hline \hline \multicolumn{1}{|c|}{19} & Metrópole em sinfonia: história, cultura e música popular em São Paulo nos anos 30 \\
\hline AUTOR: & José Geraldo Vinci de Moraes & GRAU: & Doutorado \\
\hline ORIENTADOR: & Elias Thomé Saliba & ANO: & 1997 \\
\hline UNIVERSIDADE: & USP / FFLCH & ÁREA: & História \\
\hline
\end{tabular}

Reconstrução da história da cidade de São Paulo nos anos 1930, a partir da cultura e, sobretudo, da música popular. A década de 1930 é decisiva na construção da metrópole industrial: a "cidade do trabalho", a "cidade que não pode parar" são tradições inventadas naquele momento de incessantes transformações urbanas e econômicas de São Paulo. A música popular também passava por um momento de definição no país e em São Paulo. Os meios de comunicação, especialmente o rádio e a indústria fonográfica, tiveram papel de destaque na instituição da música urbana tanto no aspecto estético e metódico como na profissionalização do artista popular. No período de profundas influências e confluências de acordes dos batuques e do virtuosismo da música erudita, os gêneros urbanos ainda em construção, como o samba, o choro, e as serestas sofreram profundas transformações. Neste novo ambiente urbano industrializado, a música popular teve um papel importante na construção, representação e avaliação do novo cotidiano paulistano.

Metrópole em sinfonia: história, cultural e música popular na São Paulo dos anos 30. São Paulo: Estação Liberdade, 2000.

\begin{tabular}{|l|l|l|l|}
\hline \hline \multicolumn{1}{|c|}{20} & Ponteio na cidade: música caipira e identidade social \\
\hline AUTOR: & Nelson Martins Sanches Júnior & GRAU: & Mestrado \\
\hline ORIENTADOR: & Benedito Miguel Ângelo Perrini Gil & ANO: & 1997 \\
\hline UNIVERSIDADE: & UNESP / FCL - Assis & ÁREA: & História \\
\hline
\end{tabular}

Resumo:

Esta pesquisa enfoca a música caipira presente na Grande São Paulo a partir dos anos 60, e mostra o papel que exerceu no processo de readaptação dos contingentes de migrantes oriundos do próprio Estado de São Paulo como também de Minas Gerais, Mato-Grosso, Goiás e Paraná. Este processo de reordenação simbólica dos valores caipiras transformou sensivelmente a música caipira, principalmente a partir do momento em que esta se associou à indústria cultural, quando então seu enfoque passou a se preocupar com novas temáticas como 0 saudosismo e 0 anti-urbanismo. Também gerou instituições como a Casa do Violeiro do Brasil - reduto da cultura caipira na metrópole. Estes elementos forneceram ao migrante uma ponte imprescindível entre o velho e o novo sertão, representados respectivamente pela antiga realidade do campo (caipira-roceira) e os novos valores exigidos pela difícil vida urbana.

Obs: Este trabalho encontra-se extraviado, segundo informação da biblioteca da FCL-Assis, não existindo nenhuma cópia disponível em outra biblioteca. 


\begin{tabular}{|l|l|l|l|}
\hline \hline \multicolumn{1}{|c|}{21} & No ar: amores amáveis - um estudo sobre a produção do amor na música brasileira 1951-1958 \\
\hline AUTOR: & Wolney Honório Filho & GRAU: & Doutorado \\
\hline ORIENTADOR: & Antônio Pedro Tota & ANO: & 1998 \\
\hline UNIVERSIDADE: & PUC / SP & ÁREA: & História \\
\hline
\end{tabular}

Resumo:

O sentimento de amor paixão compõe-se como uma experiência fortemente acentuada no dia-a-dia de homens e mulheres em geral. No nosso caso, investimos no estudo da promoção deste sentimento através de músicas românticas, principalmente aquelas que foram veiculadas como músicas de sucesso. Em especial, canções de amor interpretadas por Angela Maria no inicio de sua carreira, na década de 50.

0 cenário principal de investigação dos arroubos sentimentais característicos desta época foram as páginas da Revista do Rádio. Este periódico teve uma forte inserção social durante toda a década de 50 , atingindo 0 segundo lugar de veiculação nacional, perdendo somente para a revista $O$ Cruzeiro.

Pautando-nos especialmente nas letras das músicas, procuramos resgatar alguns movimentos de promoção do amor, como um modo específico e singular de sentir emoção, no interior dos circuitos culturais da época, privilegiando os periódicos especializados sobre o mundo da música. Inter-relacionamos letras de músicas, vida dos intérpretes e estratégias editoriais como um meio de conectar esta ebulição sentimental a uma narrativa historiográfica.

Assim, evitando cair nas armadilhas de histórias de amor passional, procuramos resgatar práticas culturais que tiveram no tema do amor uma referência simbólica para aprimorar tanto o mercado musical quanto o imaginário dos amores vividos, sofridos, chorados, enfim, amados.

\begin{tabular}{|l|l|l|l|}
\hline \hline \multicolumn{1}{|c|}{22} & A MPB em movimento: música, festivais e censura (1965 - 1969) & \multicolumn{2}{l|}{} \\
\hline AUTOR: & Ramon Casas Vilarino & GRAU: & Mestrado \\
\hline ORIENTADOR: & Maria Angelica V. M. C. Soler & ANO: & 1998 \\
\hline UNIVERSIDADE: & PUC / SP & ÁREA: & História \\
\hline
\end{tabular}

Resumo:

Neste trabalho, resgata-se a MPB como um movimento dentro da musica brasileira, caracterizado pelas mensagens de cunho sócio-político em suas músicas, que teve nos festivais da década de 60 um espaço privilegiado para constituição e desenvolvimento.

Os festivais, que tiveram o seu período áureo nos anos 1965 a 1968, abriram espaço para a apresentação de jovens compositores e intérpretes que se consagraram com canções que traziam em seu bojo muitas das preocupações daquela época, onde a música constituía-se num veículo de denúncia e crítica dos problemas existentes, incitando a uma reflexão acerca das arbitrariedades sócio-políticas e contribuindo também para uma politização maior do seu público.

Em 1969, com o endurecimento da censura e da repressão, os festivais abriram espaço para outros talentos e outras composições em muito esvaziadas daqueles atributos que os marcaram até 1968.

A MPB em movimento: música, festivais e censura. São Paulo: Olho d’Água, 1999. 


\begin{tabular}{|l|l|l|l|}
\hline \hline \multicolumn{1}{|c|}{23} & \multicolumn{3}{|l|}{$\begin{array}{l}\text { Jovens tardes de guitarras sonhos e emoções: fragmentos do movimento musical Jovem } \\
\text { Guarda }\end{array}$} \\
\hline AUTOR: & Ana Barbara Aparecida Pederiva & GRAU: & Mestrado \\
\hline ORIENTADOR: & Maria Izilda Santos de Matos & ANO: & 1998 \\
\hline UNIVERSIDADE: & PUC / SP & ÁREA: & História \\
\hline
\end{tabular}

Resumo:

Essa Dissertação de Mestrado resgata a trajetória do movimento musical-cultural Jovem Guarda ocorrido na década de 60, através das canções e da imprensa (jornais e revistas) da época, assim como dos depoimentos recolhidos pela autora com os seus participantes.

Pretende-se também, através de análise dos perfis de gênero: masculino e feminino, e de geração: juventude, questionar o conhecimento histórico sobre o movimento, criando instrumentos para avaliações críticas, rastreando as diversas formas de viver e pensar desses jovens e buscando captar as experiências de uma época.

\begin{tabular}{|l|l|l|l|}
\hline \hline \multicolumn{1}{|c|}{24} & O combate ao samba e o samba de combate: música, guerra e política, 1930-1940 \\
\hline AUTOR: & João Ernani Furtado Filho & GRAU: & Mestrado \\
\hline ORIENTADOR: & Maria IZilda Santos de Matos & ANO: & 1998 \\
\hline UNIVERSIDADE: & PUC / SP & ÁREA: & História \\
\hline
\end{tabular}

Resumo:

Em O Combate ao Samba e o samba de combate a investigação enfoca alguns aspectos da relação entre música e política, durante o primeiro governo de Getúlio Vargas (1930-1945). Para efeito de melhor consecução e clareza destes problemas optou-se por estruturar a dissertação em duas partes principais: a primeira denominada " 0 combate ao samba" e a segunda chamada "O samba de combate". Na primeira parte deste trabalho a discussão voltava-se para os discursos que qualificavam (ou desqualificavam) os ritmos ditos populares, alegando que nestes gêneros musicais haveria um exagerado sensualismo; um apelo às tragédias do cotidiano; um sentido de paródia que desmoralizava até mesmo os fatos e personagens mais sérios; um exacerbado elogio à malandragem e um tratamento bastante depreciativo do trabalho e do trabalhador. Mais que isso, esta crítica ao samba (e aos demais gêneros tidos como populares) alegava que as letras destas composições estariam impregnadas de vícios, gírias e jargões pouco adequados ao bem falar e escrever. Este exame é feito tomandose como corpo documental principal artigos e matérias publicados pela revista Cultura Política e pelo suplemento literário Vamos Lêr!, além de outros materiais bibliográficos e hemerográficos.

Uma segunda parte deste trabalho centra-se na questão concernente ao estado de beligerância mundial e à política de "Boa Vizinhança", quando tornou-se, de algum modo, recomendável a inserção destes ritmos considerados populares e do rádio no esforço de guerra; o que amainará, porém não eliminará, as críticas acrimoniosas contra estes gêneros musicais. Todavia, ao passo que eram incorporados, mais e mais, na política de propaganda, os sambas e marchas deste período foram cristalizando um discurso de legitimação e mesmo de combate a alguns aspectos do governo: racionamento, falta de liberdade e carestia. As fontes documentais utilizadas nesta parte do estudo foram as já citadas publicações (Cultura Política e Vamos Lêr!), além de vários registros fonográficos do período (78 rpm). 


\begin{tabular}{|l|l|l|l|}
\hline \hline \multicolumn{1}{|c|}{25} & Bossa Nova é sal, é sol, é sul: música e experiências urbanas. Rio de Janeiro, 1954-1964. \\
\hline AUTOR: & Simone Luci Pereira & GRAU: & Mestrado \\
\hline ORIENTADOR: & Maria Izilda Santos de Matos & ANO: & 1998 \\
\hline UNIVERSIDADE: & PUC /SP & ÁREA: & História \\
\hline
\end{tabular}

Resumo:

Busca-se analisar a Bossa Nova centrando-se na questão do urbano, da percepção, pelas músicas, da dinâmica de um Rio de Janeiro em transformação - tanto nas maneiras de se ver a cidade, o que expressava novas formas de se ver o mundo, novas formas de ser, de agir e de se sentir (e até de se morar), como também, na ocupação sistemática de novos espaços urbanos, como a praia, Copacabana e Ipanema, enfim, em novas formas de relação tanto no âmbito público como no privado.

Desta forma, tem-se, por um lado a questão de uma cidade em transformação, e por outro, um movimento musical que trazia em si pistas de uma mudança comportamental em conformação com as mudanças deste meio urbano. Não esquecendo em momento algum que estas duas instâncias estão fortemente atreladas e não podem ser analisadas de forma separada, entende-se a noção de circularidade cultural, onde a música capta elementos do cotidiano e recoloca-os no social, influenciando formas de ser, de se viver e de olhar a cidade.

Analisa-se os projetos, símbolos e modelos comportamentais da Bossa Nova, no que eles dizem respeito à cidade na sua dinâmica histórica, em suas mudanças nas relações entre novo e arcaico, público e privado, feminino e masculino, bem como no que dizem respeito à Bossa Nova como um novo estilo de vida, para além de um novo estilo musical. Uma tentativa de rastrear a experiência urbana dos sujeitos da Bossa Nova no seu meio urbano: o Rio.

\begin{tabular}{|c|c|c|c|}
\hline 26 & \multicolumn{3}{|c|}{ Banho de lua: o rock nacional de Celly Campello a Caetano Veloso } \\
\hline AUTOR: & Christina Osward & GRAU: & Mestardo \\
\hline ORIENTADOR: & Ricardo Berzaquem de Araújo & ANO: & 1998 \\
\hline UNIVERSIDADE: & PUC / RJ & ÁREA: & História \\
\hline \multicolumn{4}{|c|}{$\begin{array}{l}\text { Resumo: } \\
\text { O objetivo deste trabalho é analisar a inserção e a difusão do rock no Brasil. Começa com o surgimento do } \\
\text { rock'n'roll nos Estados Unidos, quando o novo tipo de música pretendia apenas atender à demanda do público } \\
\text { jovem interessado no entretenimento. Em seguida, trata do rock inglês e dos posteriores desdobramentos do } \\
\text { gênero, que assume características novas. Por fim, analisa sua repercussão no Brasil, que se deu de duas } \\
\text { formas. Tem-se a princípio, uma música bem comportada que é aceita pelo público em geral. Num segundo } \\
\text { momento, especialmente a partir do tropicalismo, o rock adota um formato mais universalista e eventualmente } \\
\text { transgressor. }\end{array}$} \\
\hline
\end{tabular}

\begin{tabular}{|l|l|l|l|}
\hline \hline \multicolumn{1}{|c|}{27} & Brutalidade e jardim: as imagens da nação da tropicália & \multicolumn{2}{l|}{} \\
\hline AUTOR: & José Edson Schümann Lima & GRAU: & Mestrado \\
\hline ORIENTADOR: & Afonso Carlos Marques dos Santos & ANO: & 1997 \\
\hline UNIVERSIDADE: & UFRJ & ÁREA: & História \\
\hline
\end{tabular}

Este estudo tem como objetivo analisar as idéias e imagens de nação do movimento tropicalista, a partir das discussões em torno da música popular na década de sessenta e em perspectiva histórica. 


\begin{tabular}{|l|l|l|l|}
\hline \hline \multicolumn{1}{|c|}{28} & \multicolumn{4}{|l|}{$\begin{array}{l}\text { Lenço no pescoço: o malandro no teatro de revista e na música popular - "nacional", } \\
\text { "popular" e cultura de massas nos anos 1920 }\end{array}$} \\
\hline AUTOR: & Tiago de Melo Gomes & GRAU: & Mestrado \\
\hline ORIENTADOR: & Robert Wayne Slenes & ANO: & 1998 \\
\hline UNIVERSIDADE: & UNICAMP / IFCH & ÁREA: & História \\
\hline
\end{tabular}

O trabalho tem por objetivo, através do estudo do malandro enquanto tema de canções e peças de teatro, compreender as relações entre dois fenômenos da década de 1920. O primeiro é a reavaliação da idéia de nação ocorrida a partir do final dos anos 10. Percebe-se claramente neste momento a passagem de um projeto que visava "civilizar" o Brasil nos moldes europeus - típico da "Bella Époque"- para uma busca do que seria "típico" do país. Nascia assim a moderna face da ideologia "nacional-popular", que transformaria o samba, a mestiçagem, etc., em símbolos nacionais. 0 outro é o aperfeiçoamento da cultura de massas no Brasil, o surgimento do rádio, o aperfeiçoamento do disco e a popularização do teatro de revista são manifestações evidentes deste processo. Nesta dissertação, pretende-se argumentar que aumentou muito a presença de tipos populares como o malandro nas peças e discos durante a década de 20 em função destes dois processos de um lado, a maior aceitação de temáticas "nacionais" e "populares" de outro, o aumento do público consumidor da cultura de massas forçava a incorporação de novas temáticas.

\begin{tabular}{|l|l|l|l|}
\hline \hline \multicolumn{1}{|c|}{29} & O violão instrumental brasileiro: 1884-1924 & \multicolumn{3}{l|}{} \\
\hline AUTOR: & Sergio Estephan & GRAU: & Mestrado \\
\hline ORIENTADOR: & Antonio Pedro Tota & ANO: & 1999 \\
\hline UNIVERSIDADE: & PUC & ÁREA: & História \\
\hline
\end{tabular}

Resumo:

Este trabalho tem como objeto central a pesquisa em torno da música brasileira para violão instrumental, produzida entre o final do século XIX ate 1924.

Para tanto, analisaremos, inicialmente, a musica do período colonial do Brasil, como forma de recuperar a historicidade dos gêneros musicais, assim como as principais formas de produção musical neste período e, também, seus principais agentes.

Posteriormente, trataremos da música para violão instrumental propriamente dita. Para tanto, nos fixaremos em aspectos da trajetória dos principais violonistas do inicio do século: João Pernambuco, Américo Jacomino, 0 Canhoto e Quincas Laranjeiras, que descobrimos ser um dos mais importantes instrumentistas desta geração, apesar das raras informações disponíveis a seu respeito. Ernesto Nazaré, Chiquinha Gonzaga e Anacleto de Medeiros foram os músicos escolhidos para nos fornecer mais alguns aspectos da musicalidade desse período. Por fim, analisaremos aspectos da vida e da obra violonística de um dos mais representativos nomes de nossa música, Heitor Villa-Lobos. Seu contato com os músicos populares do Rio de Janeiro, com a música brasileira do caboclo, do sertanejo, com a musicalidade das selvas brasileiras, enriqueceu o universo técnico e composicional do violão brasileiro, com contribuições ainda não incorporadas pelo violão contemporâneo. 


\begin{tabular}{|c|c|c|c|}
\hline 30 & \multicolumn{3}{|c|}{$\begin{array}{l}\text { Cotidiano, memória e tensões; a trajetória artística das cantoras do rádio de Salvador de } 1950 \\
\text { a } 1964\end{array}$} \\
\hline AUTOR: & Raimundo Dalvo da Costa Silva & GRAU: & Mestrado \\
\hline ORIENTADOR: & Yara Aun Khoury & ANO: & 1999 \\
\hline UNIVERSIDADE: & PUC & ÁrEA: & História \\
\hline
\end{tabular}

Resumo:

Recuperar a história das cantoras do rádio de Salvador, nas décadas de 50 a 64, é tirá-las do anonimato, mostrando sua trajetória artística e cultural em Salvador. Este estudo procura compreender sua historia de vida até se formarem como cantoras do radio e como vivenciaram e apropriaram-se dos ambientes artísticos da cidade. Procura-se, a partir de suas narrativas, construir todo o ambiente de trabalho vivenciado por elas nas rádios, e em seus programas, o modo de comunicação da cidade com o rádio, e todo um jogo de interesses comercial que envolvia também as cantoras. Analisa-se a luta e resistência dessas mulheres para enfrentarem os preconceitos e os valores morais da época e atingirem seus objetivos. Essa história, para não ficar no esquecimento, só foi possível graças à História Oral que recuperou a memória dos instantes vividos pelas cantoras no meio artístico de Salvador.

\begin{tabular}{|l|l|l|l|}
\hline \hline \multicolumn{1}{|c|}{31} & Violão, violonistas e memória social nas décadas de 50 e 60 em Salvador \\
\hline AUTOR: & Carlos Edmundo Chenaud Drehmer & GRAU: & Mestrado \\
\hline ORIENTADOR: & Heloisa de Farias Cruz & ANO: & 1999 \\
\hline UNIVERSIDADE: & PUC & ÁREA: & História \\
\hline
\end{tabular}

Resumo:

Este trabalho procura refletir sobre a memória do violão, as tradições musicais e a experiência dos violonistas em Salvador, nas décadas de 50 e 60.

Com base em depoimentos orais de violonistas de tradição erudita e de tradição informal e popular, que atuaram nos ambientes musicais de Salvador naquele período e na pesquisa na imprensa da época, procuro refletir sobre as tradições musicais e as experiências sociais daqueles personagens na constituição de uma cultura violonística soteropolitana.

Na parte I - Violão e Violonistas de Salvador - busquei refletir a construção dos espaços, práticas do aprendizado e dos modos de tocar violão. 0 capítulo 1 - Tradições do aprendizado dos violonistas baianos - aborda as diferentes formações musicais, tradições e experiências de aprendizagem do instrumento desses violonistas. No capítulo 2 - Os modos de aprender e tocar: o informal e popular/ o formal e erudito - procurei refletir sobre os diálogos e tensões entre as diferentes tradições musicais que influenciaram 0 aprender/ensinar do violão em Salvador, que resultaram na descoberta das mais variadas possibilidades de estilos e técnicas de acompanhamento e solar no instrumento.

Na parte II - Trabalho, Cidade e Violão - procurei identificar os caminhos profissionais desses músicos e os espaços e ambientes de Salvador que emergiam de suas lembranças. No capítulo 3 - Sobreviver como músico: 0 exercício de muitas profissões e ocupações - procurei acompanhar a trajetória profissional dos violonistas nos diversos ofícios e profissões não musicais nos quais buscavam garantir o sustento cotidiano bem como os possiveis caminhos de afirmação na carreira musical. No capítulo 4 - Espaços, ambientes e práticas urbanas da cultura violonista - busquei recompor a performance desses depoentes em Salvador da época, seus itinerários e seus modos de circular pelo espaço urbano, traçando, através de suas lembranças, mapas culturais da cidade musical. 


\begin{tabular}{|l|l|l|l|}
\hline \hline \multicolumn{1}{|c|}{32} & O protesto dos inconscientes: Raul Seixas e micropolítica \\
\hline AUTOR: & Juliana Abonizio & GRAU: & Mestrado \\
\hline ORIENTADOR: & Zélia Lopes da Silva & ANO: & 1999 \\
\hline UNIVERSIDADE: & UNESP / FCL - Assis & ÁREA: & História \\
\hline
\end{tabular}

Resumo:

Esse trabalho reconstituiu a trajetória do roqueiro Raul Seixas visando compreender a construção do mito que se tornou, problematizando sua inserção no cenário musical, seu diálogo com outros movimentos artísticos, as temáticas que fez uso ao longo das décadas de 70 e 80.

Tornando-se um mito, Raul Seixas deixou em suas músicas as bases do que denominou Raulseixismo, que ganha cada vez mais adeptos. Para analisarmos sua mitificação procuramos os fundamentos de sua filosofia e a apropriação do seu discurso pelos fãs, seguidores ou simplesmente, raulseixistas.

\begin{tabular}{|c|c|c|c|}
\hline 33 & \multicolumn{3}{|c|}{ Eu não sou cachorro não: memória da canção popular "cafona" (1968-1978) } \\
\hline AUTOR: & Paulo César de Araujo & GRAU: & Mestrado \\
\hline ORIENTADOR: & Sônia Apparecida de Siqueira & ANO: & \\
\hline UNIVERSIDADE: & UNIRIO & ÁREA: & $\begin{array}{l}\text { Memória Social e } \\
\text { Documento }\end{array}$ \\
\hline \multicolumn{4}{|c|}{$\begin{array}{l}\text { Resumo: } \\
\text { Análise das composições de autores considerados "bregas" da música popular brasileira entre 1968-1978. O } \\
\text { trabalho preocupou-se em analisar as letras das músicas e foi completado com várias entrevistas de } \\
\text { compositores. Juntando-se aos dados da memória do vivido, o conteúdo social extraído das músicas foi possível } \\
\text { a reconstituição da sociedade a proposta de uma problemática que diz respeito à produção da obra de arte, a sua } \\
\text { comunicação, a sua aceitação pelo público, e o que é mais importante, a sua permanência na memória do povo } \\
\text { até as dias atuais. }\end{array}$} \\
\hline
\end{tabular}




\begin{tabular}{|l|l|l|l|}
\hline \hline \multirow{2}{*}{34} & \multicolumn{2}{l|}{$\begin{array}{l}\text { Seguindo a canção: engajamento político e indústria cultural na trajetória da música popular } \\
\text { brasileira (1959-1969) }\end{array}$} \\
\hline AUTOR: & Marcos Francisco Napolitano Eugênio & GRAU: & Doutorado \\
\hline ORIENTADOR: & Maria Helena Rolim Capelato & ANO: & 1999 \\
\hline UNIVERSIDADE: & USP / FFLCH & ÁREA: & História \\
\hline
\end{tabular}

Resumo:

Este trabalho aborda e problematiza historicamente as diversas formas de engajamento político e crítica cultural assumidas pela canção brasileira renovada, também conhecida como Música Popular Brasileira, entre 0 surgimento da Bossa Nova (1959) e a diluição do Tropicalismo (1969). A MPB traduziu projetos e contradições dos artistas e intelectuais envolvidos de alguma forma com o paradigma "nacional popular", tomado aqui como uma cultura política. Ao mesmo tempo, a MPB esteve no epicentro da reorganização da indústria cultural brasileira, tornando-se um dos seus produtos mais rentáveis. Através do estudo de fontes escritas e musicais, mapeamos e analisamos as imbricações destas duas facetas - veículo ideológico e produto comercial - da canção brasileira dos anos 60 , em meio às profundas transformações políticas pelas quais passava o país, sobretudo após o golpe militar de 1964.

Seguindo a canção: engajamento político e indústria cultural na MPB (1959-1969). São Paulo: Annablume/ FAPESP, 2001.

\begin{tabular}{|c|c|c|c|}
\hline 35 & \multicolumn{3}{|c|}{ A dama da boêmia: imagens de Chiquinha Gonzaga } \\
\hline AUTOR: & Lícia Gomes Mascarenhas & GRAU: & Mestrado \\
\hline ORIENTADOR: & Magali Engel & ANO: & 1998 \\
\hline UNIVERSIDADE: & UFF & ÁREA: & História \\
\hline \multicolumn{4}{|c|}{$\begin{array}{l}\text { Resumo: } \\
\text { A dissertação aborda as diversas imagens da compositora Chiquinha Gonzaga, construídas em dois momentos: } \\
\text { ao longo de sua carreira e após a sua morte. Analisando os artigos de jornal - produzidos nos dois períodos - e } \\
\text { as três biografias sobre Chiquinha, observamos dois eixos principais em torno dos quais estas imagens foram } \\
\text { produzidas: a transgressão dos limites impostos à condição feminina e a criação de uma música tipicamente } \\
\text { brasileira. }\end{array}$} \\
\hline
\end{tabular}

